Waltraud KOKOT,

Mijal Gandelsman-Trier,

KATHRIN WILDNER,

Astrid Wonneberger (eds.)

\title{
Port Cities as Areas of Transition
}

\section{Ethnographic Perspectives}

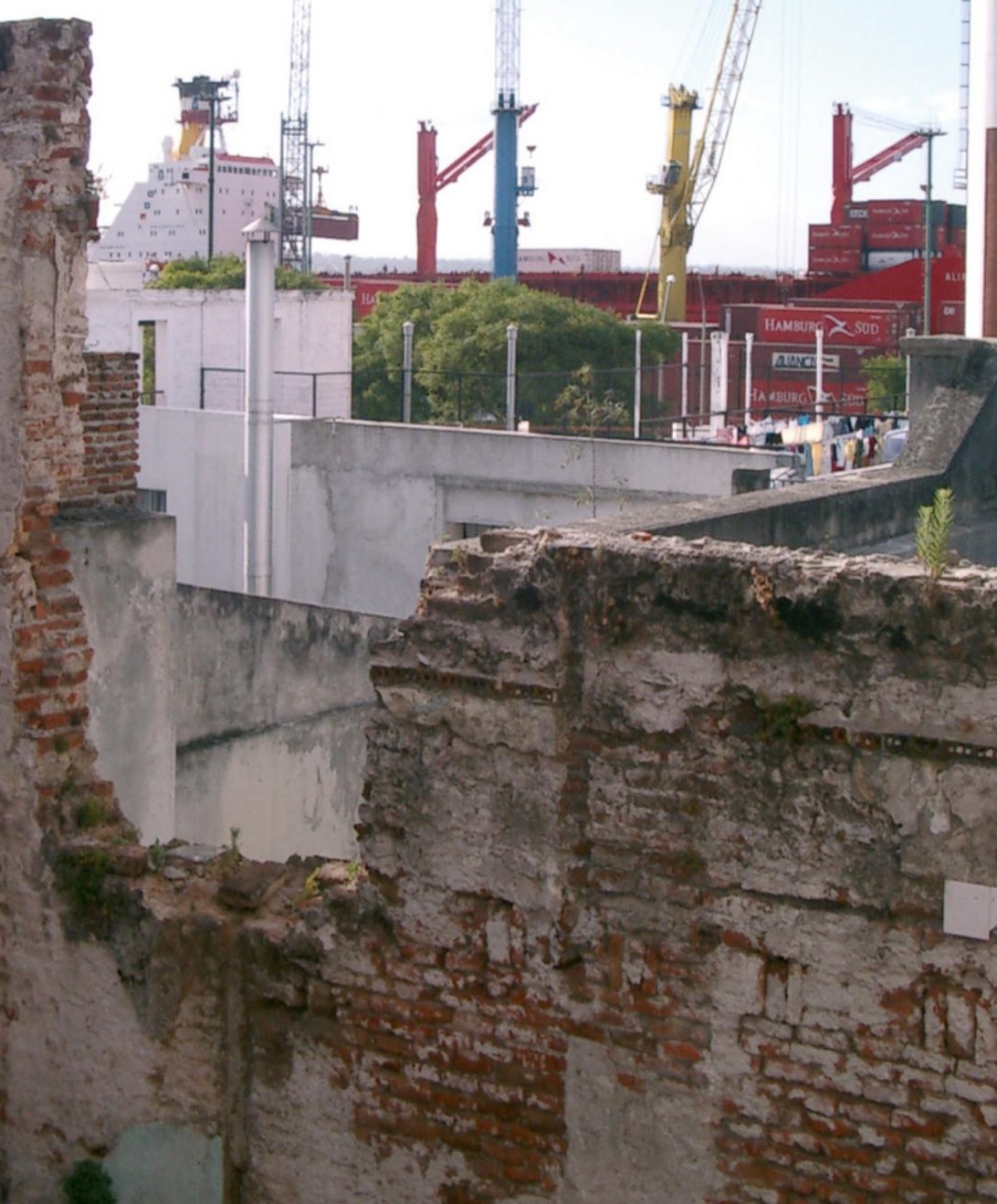

[transcript] urbanstudies 
Waltraud Kokot, Mijal Gandelsman-Trier,

Kathrin Wildner, Astrid Wonneberger (eds.)

Port Cities as Areas of Transition 

Waltraud Kokot, Mijal Gandelsman-Trier,

Kathrin Wildner, Astrid Wonneberger (eds.)

Port Cities as Areas of Transition

Ethnographic Perspectives

[transcript $]$ 
Bibliographic information published by the Deutsche Nationalbibliothek

The Deutsche Nationalbibliothek lists this publication in the Deutsche Nationalbibliografie; detailed bibliographic data are available in the Internet at http://dnb.d-nb.de

(C) 2008 transcript Verlag, Bielefeld

\section{(C) $(\Theta \Theta \Theta$}

This work is licensed under a Creative Commons

Attribution-NonCommercial-NoDerivatives 3.0 License.

Cover layout: Kordula Röckenhaus, Bielefeld

Cover illustration: Photo by Mijal Gandelsman-Trier: Montevideo 2004 Proofred \& Typeset by: Mijal Gandelsman-Trier,

Rosemarie Oesselmann, Astrid Wonneberger

Printed by: Majuskel Medienproduktion GmbH, Wetzlar

ISBN 978-3-89942-949-7 


\section{Contents}

Port Cities as Areas of Transition Comparative Ethnographic Research

WALTRAUD KOKOT

Transformation Processes on Waterfronts in Seaport Cities Causes and Trends between Divergence and Convergence

DIRK SCHUBERT

Notions on Community, Locality and Changing Space in the Dublin Docklands

ASTRID WONNEBERGER

Old Town and Dock Area:

Structural Changes in Ciudad Vieja of Montevideo

MIJAL GANDELSMAN-TRIER

A View from Port to City: Inland Waterway Sailors and City-Port Transformation in Hamburg

REIMER DOHRN

“Gateway" City and Nexus Between Two Continents:

The Port City of Algeciras

CAROLIN ALFONSO

Belém, "Gate of Amazonia" -

Port and River as Crossroads

ROSEMARIE AND DIRK OESSELMANN 
Contesting Nodes of Migration and Trade in Public Space:

Thessaloniki's Bazaar Economy

SALINIA STROUX

Varna, Capital of the Sea:

History, Image, and Waterfront Development

ANKE BOTHFELD

"Istanbul Modern" - Urban Images, Planning Processes

and the Production of Space in Istanbul's Port Area 189

KATHRIN WILDNER 


\section{Port Cities as Areas of Transition - Comparative Ethnographic Research}

\section{WALTRAUD KOKOT}

Port cities are nodes of international trade, channelling movements of cargo and flows of migration. In recent decades, international port cities have been increasingly affected by global transformation processes. Economic and technological changes have fundamentally restructured ports all over the world, dramatically altering the relation between port and city, the cities' images and representations, and the condition of people living and working around the ports. A five-stage model of the historical course of this development has been presented by Hoyle (1988, 1989, see also Schubert 2001 and in this volume), ranging from "primitive" inner-city ports, increasing industrialisation of port economies, to highly modernised container terminals far removed from the inner cities, with traditional port areas turning into urban wastelands and, eventually, into targets for urban renewal programmes.

Segments of the urban population living close to the ports, or making their living from port activities, have been particularly affected. In the context of global economic and political change, port cities have also become transit points and interfaces of transnational migration. At the same time, in many cities, historical port areas and their environs have become an object of redesigning and restructuring the urban space, and of resulting gentrification.

As Schubert (2001) points out, transformation processes in port cities have so far been mainly studied by urban geographers, economists and urban planners. Consequently, most research has concentrated on long-term development, on the position of ports in national economies, and on the physical results of urban restructuring. In view of rapid 
global change and ongoing planning processes in international port cities, this state of research urgently needs to be complemented by indepth studies of the variety of planning cultures, of goals, norms and values of actors and affected populations, and of their involvement in ever-changing balances of power ${ }^{1}$ (Schubert 2001: 34).

\section{Port-city development: historical stages in comparative perspective}

Until recently, harbours formed the core of urban development in all port cities. According to Hoyle, port-city development can be divided into five stages. Up to the $19^{\text {th }}$ century, great seaports predominantly served as markets for international staple goods of value. Harbours were integral parts of the city, included in the urban fortification systems. Merchants' houses were located close to the water, combining all the functions of dwelling, storage, trade and business administration.

The second half of the $19^{\text {th }}$ century through to the early $20^{\text {th }}$ century was marked by increased industrialisation and the expansion of cityports. More space was needed for steamships and steam-driven cranes. The ports turned from sites of trade to nodes of traffic and transport. The city expanded with the port, new port related quarters and workers' neighbourhoods developed rapidly, characterised by high population density, poor dwelling conditions and casual labour.

While the industrialisation process was basically maintained until the mid- $20^{\text {th }}$ century, the face of the ports was changed by technologic developments. Larger ships called for deep-water harbours outside of the old port areas. Modern seaports were developed instead of the old innercity ports, which frequently turned into touristic museum sites, capitalising on stereotyped port city images. When containers were introduced in the late 1960s, this process increased even further, while former port areas in or close to the inner cities turned into urban wastelands. The last phase of this development is marked by revitalisation programmes affecting the areas surrounding the port, recent examples including London's dockland development project or Hamburg's HafenCity.

The studies in this volume present a variety of cities in Europe and Latin America, exemplifying different stages and problems in the ongoing processes of social and economic transformation. To varying de-

1 "Forschungsdefizite und Fragen nach den jeweiligen Planungskulturen, nach den Zielen und Normen der handelnden Akteure und der Betroffenen und ihr Eingebundensein in veränderliche Machtbalancen drängen sich auf" (Schubert 2001: 34). 
grees, all cities involved in this project have recently undergone massive structural transformations, fundamentally changing the relationship of city and port. Local effects of this global process manifest themselves in the decline of port-related sectors of the economy and, in turn, in urban revitalisation programmes. Nonetheless, while most European cases fit quite evenly into the model proposed by Hoyle, other cities show a greater degree of variation. Some examples may illustrate this point:

The port of Dublin can be seen as a prototype, representing all stages of city-port development during its history. From a small harbour on the river Liffey within the confines of the city, the city port expanded during the $19^{\text {th }}$ century. With the building of the new Custom House, the port was relocated away from the centre and closer to the sea. During this time, port workers' communities were developed, which, after a period of retreat from the waterfront, recently became targets for dockland development urban renewal projects.

Although economic developments in Bulgaria have been shaped by socialism and post-socialist transformations, Varna's port-city development roughly fits into stages four and five of the model. Nonetheless, the inner city port is not being relocated completely to a site away from the city. Recent expansions of the port include the older parts and even foresee an expansion further along the city's waterfront.

As a major seaport, Hamburg also represents all stages of city-port development. After industrial production had been relocated between the 1960s and 1980s and container terminals called for increased storage space, port functions were removed to new locations away from the city. Former port areas are now in the process of being transformed into a new business and residential area, the "HafenCity". But Hamburg is a major node of inland waterways as well. In this respect, Hamburg's development differs from the time frame suggested by Hoyle. While Germany was separated, inland waterways were an important route for shipping cargo to West Berlin and the inland waterway port remained close to the inner city. In the 1990s, after Berlin had lost its island status, the inland waterway port was also relocated further away from the city.

In contrast to the European examples, distinct stages of development can be identified in Montevideo, but they occur in a different temporal order. These differences are mainly due to different historical developments in Europe and Latin America. Parallels do exist chiefly in the context of technological change and effects of globalisation. The first phase of "primitive" inner city port ranges from the city's foundation in 1724 until the end of the $19^{\text {th }}$ century, including various historical periods from colonialism to mass immigration from Europe. The second half of the $19^{\text {th }}$ century was characterised by great demographic and 
economic transformations, resulting in an expansion of the city port at the turn of the century and initiating the stage of expanding city port according to Hoyle's model. For Montevideo, the second stage blends into the third. Different from Europe, in Uruguay the 1950s mark a major economic crisis, slowing down industrial growth. Investments were stopped and Montevideo's Ciudad Vieja fell into decay. Also different from the European example, there has not been a significant retreat from the waterfront, marking the fourth stage in the model. The location of the port has not been changed; it still remains close to the city. Consequently, there are only few projects relating to revitalisation of the waterfronts or of port related quarters. Nonetheless, there has been a slow process of urban renewal since the 1990s.

\section{Images, representations and "planning cultures": the port, the coastline and the sea}

While cities in general have been defined in terms of size, density and heterogeneity (Wirth 1938), as well as sites of rapid social change, port cities in particular seem to epitomise these features. Consequently, port cities have triggered a wide range of imaginations and projections, blending fantasies of freedom and faraway places with images of danger and moral decay. As Schubert (in this volume) points out, literary and cineastic depictions of port cities have become a genre in its own right, founded in the early $20^{\text {th }}$ century by writers like Erasmus Fischer (1927), a travel journalist and (self-styled) "ex-mariner" who evoked "[...] das Hafenleben und sein sittliches Niveau, sein Treiben und Blühen, seine Laster und seine Geheimnisse [...]. Das gesteigerte, zügellose, in seinen Begierden rasende Leben der Hafenstädte erfordert eine ungeschminkte Darstellung, die nicht von falscher Prüderie durchsetzt ist [...]"2, for an audience both shocked and fascinated by the dark and devious side of the ports.

On a more serious level, stereotypes and imaginations relating to the port, the sea and to international waterways and migration, are still an important topic in the process of urban transformation affecting port cities. Consciously or unconsciously, these images inform the goals and values underlying urban planning and decisions relating to the built environment.

2 "The morals of port life, thriving and blossoming vices and secrets [...] the feverish, unbridled, crazed and craving life in port cities asking for an uncensored report, unhampered by false prudishness [...].“ (Fischer 1927: 13) (Translation: Waltraud Kokot) 
Of all cases presented in this volume, Hamburg most explicitly capitalises on its maritime image, although the active port area is off limits to most inhabitants and the river Elbe is a barrier not only to physical mobility. In mental representations of the city, the river also tends to act as a sharp divide of local identities. Nonetheless, Hamburg presents itself as a maritime port city, first and foremost. At the core of this representation is the former inner city port with adjoining quarters and storehouses, which are now being transformed into recreational areas. The building sites of the new "HafenCity" are incorporated into maritime tourist attractions. Media events like the yearly (rather fictitious) "Port Birthday" or public celebrations of the arrival of major vessels like the "Queen Mary" underline the economic and symbolic significance of the port.

In contrast, Dublin's relationship to the port is not easy to grasp. Distinctive differences exist between Dublin as a city, the dockland area and some port-related communities. Much different from Hamburg, the Dublin port area has up to now not been utilised as a tourist attraction, and in the general view of Dublin's inhabitants the port is virtually nonexistent, despite its economic importance. Before the regeneration of the docklands, this area did not figure in most Dubliners' mental maps either. If it was mentioned at all, it was mainly stereotyped as a dangerous, high-crime, no-go area. Presently, in the course of urban renewal projects, the image of the dockland area is slowly changing. The docklands have gained a new presence in the public view, but they are being presented to visitors and tourists as examples of new architecture rather than as a port area. While the port still does not figure predominantly, the presence of water has become an asset enhancing the docklands' qualities as a residential area. In contrast, the port was always of prime importance to the surrounding communities and neighbourhoods as a major supplier of work. Even though port-related labour has virtually disappeared from these communities, this close relationship is still reenacted by community festivals and port-community initiatives. All dockland communities keep a close relationship to their history and traditions, emphasising a working class-identity relating to the industrial port, the docks and the river. The sea as such, or any maritime imagery, does not figure strongly in every day life, or as symbols of identity formation.

Although a major port city, Varna presents itself explicitly as Bulgaria's "Capital of the Sea", while the port itself does not figure prominently in the city's public representation. Varna's central location relating to the sea is not the port, but the "Sea Garden", a large park stretching out from the inner city along the coastline, offering various 
recreational facilities to inhabitants and tourists. The beaches along the Sea Garden connect the city to the ocean, circumventing the port areas, which are still considered as dangerous and undesirable.

A parallel situation can be observed in Thessaloniki. Even though parts of the port area have been opened to the public and former warehouses were turned into shops and museums, public acceptance of these areas remains relatively low. While the recently rebuilt and gentrified Ladadika quarter close to the port has turned into a popular recreational area, its port and maritime functions have disappeared completely and do not figure at all in the public representation. Similar to Varna, Thessaloniki presents itself as the "Bride of the Sea", but again it is the coastline, not the port, that forms the core of this imagery.

This also applies to a certain degree to the case of Istanbul. Historically, the city has grown along the waterfronts, and water remains a central point of reference and of orientation. The vistas onto the water, and the urban silhouette seen from the water, are major elements of image-making and of identification for its inhabitants. Nonetheless, Istanbul presents itself not primarily as a port city, but as a city on the sea shores, surrounded by water.

Also in Montevideo, the city and the sea are closely related, although again, the port itself only plays a minor role in the city's representation. Montevideo was founded on the peninsula that now is the Ciudad Vieja, close to the mouth of the Rio de la Plata. Montevideo has more than 20 $\mathrm{km}$ of coastline, and the road along the coast, the rambla is a central point of reference for its inhabitants, serving both as thoroughfare and as a place of recreation. The beaches also are important leisure areas, attracting all strata of Montevideo's society. In the Ciudad Vieja there are no beaches and access to the waterfront is limited, because the coastline is blocked by the expanding port. Nonetheless, vistas onto the sea are considered as major assets of Ciudad Vieja. Many houses have terraced roofs, and streets offering a view to the sea are protected in the city's ground plan. While there is no explicit reference to Montevideo as port city similar to Hamburg, maritime images do appear in representations of the city, mainly in the visual arts.

\section{Revitalisation and gentrification in port cities}

In a recent volume on urban ethnicity, Erdentug and Colombijn (2002) refer to a globally interconnected network of major cities as nodes of "cultural flows", standing in marked contrast to peripheral zones, which are bypassed by relevant economic, social and cultural level develop- 
ments. Major port cities are exemplary nodal points in the complex system of international labour and trade (Läpple 1994: 462) at the crossroads of main transport routes (Schubert 2001: 16). As global cities in general, they are highly competitive to each other (Sassen 2001). In order to improve their position in the global network, municipal governments have been creating infrastructures and policies encouraging investment and the establishment of new business enterprises, the professionalisation of labour and high-end recreation and consumption, to reorient the cities to the real and imagined interests of globally mobile investors (Sassen 1994, 2001; Loftman/Nevin 2003).

"The role of urban planning in the context of competitive city strategies is to facilitate the redevelopment of the built environment and engage in place marketing in order to ameliorate conditions for such interurban competition." (Cowan/Bunce 2006: 429)

The redevelopment of urban waterfronts in cities with declining traditional industries is one major aspect of the agenda of the competitive city, and has been a hallmark of urban revitalisation strategies since the 1980s (Hoyle 1988, 1989; Schubert 2001 and in this volume). The privileged location of urban waterfronts, their centrality close to downtown financial and commercial districts, and their capacity for leisure-, residential- and commercial development, make them an attractive focus for urban renewal projects. The waterfront provides the developers with space where space is scarce - close to the city centres.

"The redevelopment of urban waterfronts into gentrified residential and commercial areas produces new spaces for investment and accumulation and provides symbolic visuals for entrepreneurial 'city branding' campaigns." (Cowan/Bunce 2006: 429)

The concept of gentrification refers to specific processes of urban restructuring, affecting urban areas that once were considered desirable, but have fallen into dereliction. Their investment potential lies either in their specific location (e.g. close to the city centres or to the waterfront), or in historically interesting buildings, which may at least partially be renovated and put to new uses in the process. Frequently, the actual gentrification process is preceded by "pioneers" (students, artists, etc.), who move into the area attracted by low rents and unusual locations. In turn, the new lifestyles and cultural activities developed by the pioneers attract the influx of actual "gentrifiers": middle-class residents who are able to invest into the renovation of dilapidated buildings, or who have 
sufficient means to rent or buy accommodations renovated by professional investors.

These projects may serve to keep the city competitive in different aspects, but they frequently lead to social exclusion. Due to the restoration of buildings and the ensuing raises in rents, or the transformation of rented space to tenant-ownership, former residents may be forced to leave the gentrified areas. Thus, the concept of gentrification is closely related to process of urban segregation. Various theoretical approaches have been offered to explain the development of gentrification. Hamnett (1991), Lees (2000) and Slater (2004) suggest a synthesis, offering a multi-dimensional model including economic factors like rent gaps (Smith 1979), as well as consumer preferences of the new middle classes (Ley 1986, 1996).

In this volume, most case studies explicitly refer to urban transformation processes that might be labelled "gentrification", but some of these cases do not fit entirely with the common use of the term. In the case of Montevideo's Ciudad Vieja, the influence of residents' movements and local decision-makers has been strong enough so far to prevent actual gentrification, while in the case of Varna, urban revitalisation follows entirely different preferences: not the inner-city areas close to the port are considered as desirable, but a park close to the sea coast is now in danger of becoming a building site.

In the revitalisation of former inner-city port areas, the aspect of social exclusion may seem less prominent because in most cases they were not used as residential areas before (e.g. Hamburg's HafenCity, or Thessaloniki's port area and Ladadika quarter). Nonetheless, as these examples show, social exclusion is not only limited to the displacement of former inhabitants, but can also affect the working and living conditions of former port-related professions or marginalised groups like migrants. In the inner-city ports, work functions are being replaced by residential functions, and the new residents may not relate at all to the history and imagery of the port workers. The case of Dublin however, demonstrates open clashes between the symbolic representations of former port workers and the life style of new residents.

\section{Migration, diaspora and urban space}

Port cities have also always been nodes of migration, concentrating ideas, economic and material goods, migration and exile. Connected to world wide networks, port cities have been points of arrival and of departure for numbers of migrants, many of them remaining as expatriate 
communities of traders or merchants, who in turn fostered the cities' development by their transnational connections and left their mark on the urban space. Even today, many of the centres of old diasporas are still attracting new communities - be it networks of business or scientific elites, or immigrants and refugees turning into diasporas in the second or third generation.

Since the beginnings of urban ethnography in the 1920s Chicago School, ethnicity and ethnic diversity in cities have been a major research interest, underlining the significance of the urban context for interethnic relations and cultural exchange:

„Hence, inter-ethnic relations are more likely to develop in cities than in villages, because the diversity of services and opportunities offered by cities attracts a larger variety of people than a village economy." (Erdentug/Colombijn 2002: 1)

Research paradigms developed in the Chicago School emphasised ethnic enclaves and the competition about urban territory among migrant groups. Segregation and mutual exclusion were treated as the dominant patterns of urban ethnicity.

Globalisation and transnational migration have introduced a change of focus in the study of urban space. "Global cities" have been analysed as central nodes of global networks, in which, according to Manuel Castells (1996), different "flows" come together, creating a "space of flows", in contrast to a "space of places", which are bypassed by global networks and development. This increasing polarisation characterises not only the relation between cities. Massive social and economic transformations also leave their mark on the physical shape of the built urban environment; gentrification processes create new forms of segregation and ethnic exclusion. These processes shed a new light on the development of ethnic urban space.

More research on the specific interrelations between migration and urban space is needed, exploring the interdependence between the development of migrant and diaspora communities, and transformations of urban space. Actors' choices can be enabled or constrained by the space they live or work in, while different groups use space in culture-specific ways, thus actively shaping the urban environment. Diasporas differ from the ethnic enclaves described in the older literature by their ongoing relations to home countries and to a global network of communities. In some periods, ethnic enclavement and spatial segregation were either directly forced on diasporas, or they were an option because they offered at least some measure of protection (e.g. Calimani 1990; Cesarani 2002). 
As the case of Thessalonki shows, differentiation and even segregation of space in multiethnic cities may be utilised in the process of image-building - but only to a certain degree. Thessaloniki presents itself to a European audience as a cosmopolitan city with a rich multicultural history, while present-day new immigrants surviving as street vendors are subject to social exclusion, but also make use of this image in their specific marketing strategies. Trade is also a major activity of migrants both in Algeciras and in Belém, where they leave their mark on the urban space particularly in the central market areas close to the ports.

\section{Ethnography: studying local effects of global transformation}

The contributions to this volume are based on ethnographic field work in eight port cities in Europe and Latin America, representing different stages of port-city development. Following Schubert's suggestion, these case studies attempt to contribute an ethnographic approach, focusing on the relevance of urban imagery in planning processes, on local effects of urban transformation and gentrification, and on local actors' viewpoints in port-related ethnic and working class neighbourhoods.

The ethnographic ${ }^{3}$ research perspective is characterised by a closeup focus on local actors' ways of life, on their specific cultural knowledge, and on their everyday activities. The distinctive feature of ethnographic field work ${ }^{4}$ as compared to other social science approaches is the researchers' close and long-term personal contact with the actors under study, enabling intensive participant observation of their everyday lives. Focusing on local cultures, in the sense of individuals' views, knowledge and strategies of action, the ethnographic perspective provides a unique approach to investigate local effects of global structures

3 There is considerable terminological confusion relating to ethnographic research. Ethnology, or social/cultural anthropology (in Germany: "Ethnologie") is the comparative study of culturally determined varieties of human behaviour and of social organisation. Different from other usages, the German term "Ethnologie" does not imply a distinction between social and cultural topics of research. The term "ethnography" generally refers to the process of data collection in the field, as well as to the resulting descriptions. In this paper I use the term "ethnography" when referring to the research process, while "ethnology" refers to the academic field.

4 Methods of ethnographic field research include participant and nonparticipant observation, various techniques of interviewing, social network analysis and a range of specific elicitation techniques directed at cognitive, economic and socio-demographic data. 
and transformations. Providing an insiders' point of view, it can serve as a much-needed empirical corrective to more abstract, macro-level theories of globalisation. By nature of this local perspective, ethnographic research to a large extent has been descriptive and caseorientated. Nonetheless, theories on the variability of human culture and social organisation are formulated and tested on the basis of systematic crosscultural comparisons.

Ethnographic studies provide micro-level perspectives on the effects of global transformation processes, as well as systematic insights into perceptions and strategies of local actors. Although historically, ethnology has been associated with the study of small-scale societies, recently ethnographic methods have been applied to various aspects of complex societies as well. In the past decades, urban and migration studies have become fields of major relevance for ethnological research. ${ }^{5}$ Nonetheless, urban ethnographers are confronting specific methodological challenges. Only in rare cases, contemporary urban fields still consist of clearly demarcated spatial sites. More often, the fields studied by urban anthropologists consist of social networks spreading across various parts of the city, extending beyond its spatial limits, or even - as in the case of migrant communities - transcending the boundaries of nation-states as well.

\section{The case studies: sites and topics of research}

Since 2001, a team of urban ethnologists at the University of Hamburg has been studying local effects of global transformation in European ${ }^{6}$ and Latin American port cities. Historically, European port cities were sites where cargo was predominantly imported, and emigrants departed to overseas destinations. In Latin American port cities, these tendencies were partially reversed: goods were exported to Europe, while the ports served as points of entry for immigrants. As the choice of field sites was mainly based on pragmatic criteria such as access and previous research experience, the focus of these studies varies according to differing na-

5 For recent ethnographic studies of social exclusion and urban poverty see e.g. Desjarlais 1997; Ferrell/Hamm 1998; Gigengack/van Gelder 2000.

6 Part of this research was conducted within the framework of a joint European project under the EU "Community Action Programme to Combat Social Exclusion". This cooperation was mainly directed at strategies of subsistence and social organisation of local actors affected by social exclusion, resulting in policy-orientated reports (Kokot 2006a and 2006b). 
tional and local conditions, representing different stages in the relationship of city and port.

Nonetheless, all studies share a common set of basic assumptions and general questions of research. Taking the five-stage model of cityport development (Hoyle 1988, 1989) as a common point of departure for all projects, research topics and questions were jointly developed (and constantly adjusted during the research process), in order to provide a common theoretical framework and to ensure at least a modest level of comparability. All studies are based on ethnographic fieldwork, either in neighbourhoods and communities (once) related to the ports, or, as in the case of Varna, Montevideo and Istanbul, also among architects, artists and decision makers actively involved in urban renewal.

The papers in this volume represent the challenges of a wide variety of urban fields, ranging from traditional dockland communities with a long history of local identity and strong attachment to place, over inland waterway sailors whose work and everyday routine is affected by port and waterfront revitalisation programmes, to active agents of gentrification such as international urban planners designing new concepts for port and dockland areas. Other studies focus on new types of international migration and exile, which are closely related to the role of port cities as centres of nodes of human traffic and centres of diaspora formation.

A central focus of these projects is on the situation and social practice of local actors directly affected by change in port areas. In most cases, these changes are related to gentrification processes in the course of urban renewal projects. Most communities close to the inner city ports had already lost their economic connections to port and docks, long before the onset of this process. Nonetheless, in many cases the port-related history of these neighbourhoods still acts as an important factor in shaping local identities, while often migrant and diaspora communities have also concentrated in these areas, setting a distinctive mark on the urban space. Consequently, a second focus of research is on port city images, both referring to local identity formation by their inhabitations, and to deliberate processes of image-building in the course of urban planning and renewal policies.

Analysing urban transformation processes in the Dublin docklands, Astrid Wonneberger focuses on the impact of physical changes of urban places and spaces on the structure and every-day practice of dockland communities. New boundaries - on an administrational as well as on a physical level - create new forms of social exclusion. Also, many residents perceive the demolition of old buildings and the rise of new architectural design as a threat to community structure and identity. The 
analysis of the micro-level demonstrates the interrelations of the physical urban environment, the social structure of dockland communities, and the formation of local identities and culture.

Mijal Gandelsman-Trier gives an insight into characteristic features of structural change in Ciudad Vieja of Montevideo, the historical centre and port-related district of the city, focusing on consequences of global transformations on the local level and emphasising the specific perspective of the city of Montevideo. Although structural changes can also be related to global aspects of transformation, processes of change in Montevideo's Ciudad Vieja do not correspond to only one form of transition. Ciudad Vieja is a heterogeneous and multi-faceted district: historical city centre and residential area; representative location for public and private institutions, as well as a living quarter for poorer segments of the population; tourist attraction and dockland area. She analyses urban transformations in Ciudad Vieja, stressing simultaneous development as well as contradictions. Transformation takes place within the scope of urban planning programmes, aimed at decentralisation and participation on the local level and initiating a variety of different discourses and practices. This paper explores current processes of change, local actors' practices and strategies, as well as implications of the portcity-interface.

The port of Hamburg is a central node connecting worldwide trade routes with the European hinterland. Most cargo is distributed in this network by inland waterway ships. Sailors working on these ships have been active users of the port, introducing a unique perspective to Hamburg's port and city from the waterside. Their economic strategies as well as their daily routines are immediately affected by the current transformation of Hamburg's port to container service, moving further away from the city, as well as by the waterfront revitalisation project "HafenCity". In his article, Reimer Dohrn analyses these effects on local and personal levels, presenting the inland waterway sailors as an example for groups without a strong lobby, who are in danger to be forgotten in the process of developing a new waterfront image.

Algeciras is located on the crossroads of one of the busiest international sea-lanes on the Strait of Gibraltar. During the last 50 years, Algeciras has become the leading Spanish port, surpassing all other Spanish port cities, and forming a bridge between Europe and Northern Africa. This is reflected in the passenger and vehicle traffic on the ships that work the Straits. Each year, more than four million people and over one million vehicles make the crossing, for the most part during summer time. In her fieldwork, Carolin Alfonso concentrates on the effects of the rapid transformation in a city coined by an omnipresent air of transience. 
Taking the central market place close to the port as an ethnographic point of departure, she focuses on local actors' strategies of coping with cultural diversity in a relatively small port city.

The geopolitical importance of Belém (Brazil) lies above all in its function as "Gate of Amazonia". On one hand, Belém gives access to the most extensive river system on earth and thus to the riches of the Amazonian rain forest, which are transported via the rivers to the international port of Belém and then exported abroad. On the other hand, for the native population the river Guamá and its many, partly informal, port facilities are vital destinations of transition from the interior to the city and offer the only possibilities of access to markets and means of information and communication. In their article, Rosemarie and Dirk Oesselmann investigate economical, social and cultural movements around the port, in the context of the various phases of historical development. They also focus on processes of change and their effects on the local population. These processes mirror the development of a society divided socially and separated geographically in the different districts of the port area.

The port city of Thessaloniki has a long tradition as a node of migration and trade. Situated at the crossroads between Europe and Asia and connecting the European Union with the former Eastern Block and the Orient, the city has always played a major role in networks of trade and migration. In her article, Salinia Stroux shows how local policy and public discourse have shaped the image construction of Thessaloniki as a multicultural European port city and how this is manifested in public space. On the other side, the same imagery is implicitly used by irregular migrant street vendors in a very pragmatic way for their daily survival. Thus, divergent interpretations of the city image lead to conflicts about public space. In the context of global, national and local transformation processes, the street markets of Thessaloniki have become a conflict zone, a crossroads where competing interests come to the fore.

"Image building" is an important part of waterfront revitalisation. Varna, Bulgaria's most important port situated at the shores of the Black Sea and at the banks of the Varna Lake, has been labelled the "Capital of the Sea". So far, neither the port nor the lake figures in this image. In Varna as elsewhere, waterfront revitalisation is not a one-directional process automatically following the retreating ports. It is also the outcome of debates and competing models among urban decision makers, whose plans and projects are to a great degree motivated by public images. Anke Bothfeld analyses the discourse and images of planners and decision-makers, and the resulting transformations of Varna's waterfront, in relation to local, regional and global developments. 
Since the early $20^{\text {th }}$ century, industrialisation and modernisation have influenced the development of Istanbul's historic waterfront. At the beginning of the $21^{\text {st }}$ century, urban development projects have been proposed for former port areas of the Golden Horn and the Bosporus. Istanbul Modern, a recently opened museum of modern art located in a former warehouse on the waterfront, is part of the ambitious Galata Port Project, which has been the topic of architectural contests and public debates, which are part of an ongoing discussion about public space and "cultural industries" as impulse for urban renewal. Focusing on the museum and on the Galata Port Project, Kathrin Wildner explores the significance and images of the waterfront, in the context of urban transformation in Istanbul.

\section{References}

Castells, Manuel (1996): The Information Age: Economy, Society and Culture, Vol. 1: The Rise of the Network Society, Cambridge, Mass. et al.: Blackwell.

Calimani, Riccardo (1990): Die Kaufleute von Venedig. Die Geschichte der Juden in der Löwenrepublik, Munich: Deutscher Taschenbuch Verlag.

Cesarani, David (ed.) (2002): Port Jews: Jewish Communities in Cosmopolitan Maritime Trading Centers, 1650-1950, Abingdon: Frank Cass.

Cowan, Deborah/Bunce, Susannah (2006): "Competitive Cities and Secure Nations: Conflict and Convergence in Urban Waterfront Agendas after 9/11". International Journal of Urban and Regional Research 30 (2), pp. 427-439.

Desjarlais, Robert R. (1997): Shelter Blues. Sanity and Selfhood among the Homeless, Philadelphia: University of Pennsylvania.

Erdentug, Aygen/Colombijn, Freek (eds.) (2002): Urban Ethnic Encounters. The spatial consequences, London/New York: Routledge.

Ferrell, Jeff/Hamm, Mark S. (eds.) (1998): Ethnography at the Edge. Crime, Deviance and Field Research, Boston: Northeastern University Press.

Fischer, H. Erasmus (1927): "Sittengeschichte des Hafens und der Reise”. In: Leo Schidrowitz (ed.), Sittengeschichte der Kulturwelt und ihrer Entwicklung. Sittengeschichte des Hafens und der Reise, Vienna: Verlag für Kulturforschung. 
Gigengack, Roy/van Gelder, Paul (2000): “Contemporary Street Ethnography: Different Experiences, Perspectives and Methods". Focaal 36, pp. 7-14.

Hamnett, Chris (1991): "The Blind Man and the Elephant: The Explanation of Gentrification". Transactions of the Institute of British Geographers 16 (2), pp. 173-189.

Hoyle, Brian (1988): "Development Dynamics at the Port-City Interface”. In: Brian S. Hoyle/David A. Pinder/M. Sohail Husain (eds.), Revitalising the Waterfront. International Dimensions of Dockland Redevelopment, London/New York: Belhaven Press, pp. 3-19.

Kokot, Waltraud (2002): "Ethnographie eines Straßenzuges auf St. Pauli - Ein ethnologisches Forschungsprojekt”. Ethnoscripts 4 (1), pp. 97 100.

Kokot, Waltraud (2006a): European Port Cities: Disadvantaged Urban Areas in Transition: A Collaborative Project of the Community Action Programme to Combat Social Exclusion 2002-2006. Final Report - Phase II/Year 2, Institut für Ethnologie Hamburg, Hamburg (www.europeanportcities.de).

Kokot, Waltraud (2006b): "Transformationsprozesse und urbane Subsistenz in europäischen Hafenstädten: zum Abschluss des EU-Projekts 'European Port Cities"'. Ethnoscripts 8 (2), pp. 212-220.

Läpple, Dieter (1994): "Hafenwirtschaft". Handwörterbuch der Raumforschung und Raumordnung, Hanover: Akademie für Raumforschung und Landesplanung, pp. 462-467.

Keith, Marc/Pile, Steven (eds.) (1993): Place and the Politics of Identity, London/New York: Routledge.

Lees, Loretta (2000): “A Reappraisal of Gentrification: Towards a 'Geography of Gentrification'”. Progress in Human Geography 24 (3), pp. 389-408.

Ley, David (1986): “Alternative Explanations for Inner-City Gentrification". Association of American Geographers 76 (4), pp. 521-535.

Ley, David (1996): The New Middle Class and the Remaking of the Central City, Oxford et al.: Oxford University Press.

Loftman, Patrick/Nevin, Brendan (2003): "Prestige Projects, City Centre Re-structuring and Social Exclusion: Taking the Long-term View". In: Malcom Miles/Tim Hall (eds.), Urban Futures: Critical Commentaries on Shaping the City, London/New York: Routledge, pp. 76-91.

Sassen, Saskia (1994): Cities in a World Economy, Thousand Oaks, Calif. et al: Pine Forge Press.

Sassen, Saskia (2001): The Global City: New York - London - Tokyo, Princeton, N.J. et al.: Princeton University Press. 
Schubert, Dirk (2001): "Revitalisierung von (brachgefallenen) Hafenund Uferzonen in Seehafenstädten - Anlässe, Ziele, Ergebnisse sowie Forschungsansätze- und Defizite”. In: Dirk Schubert (ed.), Hafen- und Uferzonen im Wandel. Analysen und Planungen zur Revitalisierung der Waterfront in Hafenstädten, Berlin: Leue, pp. 1536.

Slater, Tom (2004): "North American Gentrification? Revanchist and Emancipatory Perspectives Explored". Environment and Planning A 36 (7), pp. 1191-1213.

Smith, Neil (1979): "Toward a Theory of Gentrification: A Back to the City Movement by Capital not People". Journal of the American Planning Association 45 (4), pp. 538-548.

Stroux, Salinia (2001): “AG Hafenstädte". Ethnoscripts 3 (1), pp. 122123.

Wirth, Louis (1938): "Urbanism as a Way of Life". The American Journal of Sociology 44 (1), reprint in: Richard T. LeGates/Frederic Stout (eds.) (1996), The City Reader, London/New York: Routledge. 



\section{Transformation Processes on Waterfronts in Seaport Cities - Causes and Trends between Divergence and Convergence}

\section{DIRK SCHUBERT}

A few decades ago, ports without ships, empty warehouses, derelict storage sheds, disused docks and deserted neighbourhoods dominated the appearance of inner cities in many seaports. Derelict port zones, waterfront areas and water-related sites are now held in high esteem and a special interest in these places has emerged recently. Discussion on suitable and sustainable strategies to deal with the potential of these areas has opened a controversial debate concerned with practical planning as well as theoretical issues, about aims and priorities. Despite the unique potential, considerable delays between dereliction and renewal were common. The cycle of dilapidation, blight, neglect, planning, implementation and revitalisation, is part of a complex network involving stakeholders and other interests.

The process of transformation of ports and waterfronts can only be understood in the context of worldwide economic restructuring, of changes in dock labour and the urban spatial framework of city and port (Schubert/Harms 1993). The stormy and far-reaching structural change of sea trade and its related port economy brought about the complete reorganisation of working docks. The formerly close functional and spatial relationship of port and city was relaxed from the end of the 1960s onwards. Changing economic circumstances and trends of dissociation of transhipment on the one hand, and profitability and employment on the other, are found in all world ports.

Seaports were, and still are, the culmination of innovations in economy, society and culture. They are places in which the local and the exotic, the foreign and familiar, poverty and riches, tradition and moderni- 
sation and phenomena of globalisation had been anticipated (Osterhammel/Petersson 2003: 14). ${ }^{1}$ It is always in a local context that globalisation processes take effect, are adopted, mixed and refracted ("glocalisation" 2 . Seaports often served as "command centres", from which exchange and interdependency were advanced internationally and globally by creative milieus of traders, business people, finance and international companies.

No two seaport cities are alike, and no seaport of the world is like another. All have their own face, their special character and individual history. The geographical conditions, technical possibilities, historical development, constellation of stakeholders and transport connections to the hinterland are different. Internally, seaports have different zones for specialised land uses. Ferry ports, fishery, shipbuilding, ship repairs, transhipment of goods, seaport industries, the army and navy, all have specific infrastructure requirements and different relations to the urban context.

Integral parts of the fabric of ports are the "sailortowns": "special", harbour-related districts.

"Zur Blütezeit der Segelschifffahrt waren die Hafenviertel der bedeutendsten europäischen Seestädte zwischen Liverpool und Lissabon, London und Neapel, Amsterdam und Riga, Kopenhagen und Marseille einander so ähnlich wie die Dome und Kathedralen dieser Gemeinwesen oder wie die Kontore ihrer Kaufmannshäuser.”3 (Rudolph 1979: 31)

Being internationally orientated, they form conglomerates of a multitude of functions and services, including shops for clothing, beverages, tobacco and souvenirs, sailors' churches, lodgings, pubs, tattoo studios,

1 Here, globalisation is understood as a complex and ambivalent historical macro process, its beginnings extending far back to the age of discoveries. The last surge of globalisation since the 1990s can not merely be interpreted as the extension of an existing development, but must be placed in the context of long-term, interrelated processes of regional, national, international and global interdependence of production, transport and communication capacities. In doing so, phases of accelerated and arrested globalisation must be detected and contradictions identified (Osterhammel/ Petersson 2003: 14).

2 Glocalisation describes the combined process of globalisation and localterritorial reconfiguration (Brenner 1997: 12).

3 "At the height of transport by sailing ship the harbour areas of important European port cities, from Liverpool to Lisbon, London to Naples, Amsterdam to Riga, Copenhagen to Marseille, resembled each other like the churches and cathedrals of their communities, or like the offices of their merchants' buildings." (Translation: Dirk Schubert) 
dance halls and brothels. ${ }^{4}$ Jewish, Chinese and other diasporas had introduced their different ways of living, eating, working and sleeping into the seaports, while inland they were still gawked at as "exotic". Harbour districts were considered "dangerous" and were often reputed to be unsafe and "amoral". At the same time they represented the first "stepping stone" for newcomers, which opened opportunities for processes of informal adoption and development of ethnic economies. In Spanish speaking countries these port districts and hideouts of otherness are called "Barrio Chino", a term that makes reference to internationality in this instance China ("Chinatown"). ${ }^{5}$

Cross-linked to the social networks, the niches and (sub-)cultures of dockworkers and seamen ${ }^{6}-$ which had a special, exotic flair and appeal for the local petit bourgeoisie - the significant technical port infrastructure was developed. Technical innovations facilitated new and improved means of transportation over short and long distances (Borscheid 2004: 110). The interface between the requirements of sea and land transport, the docks and the port, had to be planned and organised in a way that enabled them to adapt to the ever-changing challenges of international, and finally global transportation (Löbe 1979). Decisions taken in seaport cities at the beginning of the $19^{\text {th }}$ century - on the organisation of harbour operations, on the type of harbour development or redevelopment and on housing associated with the docks - had large impact, and later were often found to be irreversible. ${ }^{7}$

4 " [...] sailortown being much the same as another - repetition can hardly be avoided. Each port had its pubs, boarding houses and brothels, with their crimps, whores [...]. Sailortowns were the same all over the world" (Hugill 1967: xvii and xxxi). This theory of uniform clusters of land uses neglects the diversity and specifics of the many sailortowns. A comparative long-term study with a focus on social and cultural aspects should be interesting.

5 Such Chinatowns are/were found in many seaport cities: Rotterdam (Katendrecht), Amsterdam, New York, Singapore, Bangkok, Havana, Panama City; they are called "Barrio Chino" in Havana and Barcelona (El Raval) (Christiansen 2003).

6 For the seamen shore leave and visiting the entertainment districts of port cities was an exceptional occurrence compared to their every-day life on the ships and at sea, which fostered a distorted picture and provided "ample material for picturesque descriptions and romanticising makeovers" (Heimerdinger 2005: 77).

7 Here, location and expansion possibilities, water depths for seafaring ships, organisational structures and options for expansion into an open tidal harbour (e.g. Hamburg), or into a dock harbour with locks (London, Antwerp) should be mentioned. 


\section{Phases of urban and port development}

Some changes in the altered relationships between port and city and long-term technological and socio-economic transformation processes can be detected on the edges of the port. Hoyle (1989) differentiates between five model development phases in the relationship between city and port. Accordingly, urban land uses and port functions are connected across a contact zone in which the port-city-system is subject to the influence and control of primary factors, such as technological changes, environment, economic development, politics and legislation. The following empirical evidence supports the apparentness of this theory.

\begin{tabular}{|c|c|c|c|}
\hline \multirow[t]{2}{*}{ Stage } & \multirow[t]{2}{*}{ Period } & Symbol & Characteristics \\
\hline & & City & \\
\hline 1. Cycle & Ancient/medieval to $19^{\text {th }}$ century & & $\begin{array}{l}\text { Primitive port/city } \\
\text { Preindustrial stage }\end{array}$ \\
\hline 2. Cycle & $19^{\text {th }}$ - early $20^{\text {th }}$ century & & $\begin{array}{l}\text { Expanding port/city } \\
\text { Stage of industrial growth }\end{array}$ \\
\hline $\begin{array}{c}\text { III } \\
\text { 3. Cycle }\end{array}$ & mid $-20^{\text {th }}$ century & & $\begin{array}{l}\text { Modern industrial port/city } \\
\text { Fordism }\end{array}$ \\
\hline $\begin{array}{c}\text { IV } \\
\text { 4. Cycle }\end{array}$ & $1960 \mathrm{~s}-1980 \mathrm{~s}$ & & $\begin{array}{l}\text { Retread from the waterfront } \\
\text { Postfordistical stage }\end{array}$ \\
\hline $\begin{array}{c}\mathrm{V} \\
\text { 5. Cycle }\end{array}$ & $1970 s-1990 s$ & & $\begin{array}{l}\text { Redeveloping of waterfront } \\
\text { Flexible accumulation }\end{array}$ \\
\hline $\begin{array}{c}\mathrm{VI} \\
6 . C y c l e\end{array}$ & $1980 \mathrm{~s}-2000+$ & & $\begin{array}{l}\text { Renewal of port/city links } \\
\text { Globalization }\end{array}$ \\
\hline
\end{tabular}

Fig. 1: Phases of port-city development according to Hoyle (1989)

Hoyle identifies the first phase of port-city development as the "primitive city harbour". Up to the mid- $19^{\text {th }}$ century the large seaports were primarily staple markets and trading centres for international high-grade goods. Numerous town plans confirm that moorings and harbours were an integral part of the city, being closely integrated into the urban fabric. This is why harbours were generally located within the town fortifications. Buildings incorporating such uses as accommodation, commercial uses, storage and offices were built immediately on the water's edge to facilitate the direct unloading of goods, or the use of barges, from the ships into the warehouses. Especially the handling of perishable goods called for the construction of warehouses from the $18^{\text {th }}$ century. A close 
spatial interdependency of city, handling of goods, storage, trade and port-related services prevailed into the $19^{\text {th }}$ century.

Industrialisation and the expansion of world trade provided the context in which disruptions and a change in scale led to transformations in the port-city relations. In the second phase, from the mid- $19^{\text {th }}$ century, the expanding city port emerges. The invention of the steam engine, the railway and steam ships revolutionised the handling of goods. With the expansion of steam shipping the timing of departures and arrivals could be calculated. At the turn of the century, sailing ships had mostly disappeared from the ports and were replaced by iron ships. The size of ships increased manifold. To cope with these changes in structure, new and larger docks had to be built, modern transhipment technology installed and the shipping lanes deepened. The handling of goods was mechanised with cranes.

The construction of new docks necessitated the expansion and reorganisation of urban areas. "Dominant trade functions of the port were replaced and extended by functions of transport and conveyance" (Läpple 1994: 463, translation: Dirk Schubert). The port facilities of pre-industrial times no longer met the requirements of modern transhipment. The close connection of port, work and living was gradually dissolved with industrialisation. The changing economic activities of the port implied an adjustment of the allocation of land uses. Quayside warehouses and storehouses replaced the sheds; offices were relocated from the harbour to the centre of town, where a dense network of banks, stock exchange, insurance and shipping companies, etc. developed.

At the same time, a dockworkers' (sub-)culture emerged, remnants of which have continued into the present. The specific type of labour, the diversity and danger of the work, the irregular workload (casual labour), the contact with foreign seamen and the life close to the docks fostered the emergence of a solidary community of dockworkers (Miller 1969: 308). Attempts to locally stabilise the irregular working hours by introducing special guild or trade union regulations further highlighted the particularity of work on the docks and its militant reputation (Phillips/Whiteside 1985: 235).

The inter-war period can be roughly outlined as the third phase of modern industrial seaports. The growth of the economy and trade went hand in hand with plans for new port extensions and industrial development. The enhancement of crane technology from steam crane to electric full gantry crane facilitated increasingly large sectors of transhipment to be mechanised. Methods of shipbuilding changed from the rivet method of construction to welding technology, which considerably sped up the construction of vessels. (Seaport) industries were established alongside 
existing commercial activities and transformed the harbour landscape with silos, cold storage houses and tank farms.

The trend for ever larger vessels necessitated further dredging of the shipping lanes and required special cargo handling facilities ("ships design the port"). Increasing oil consumption caused by mass motorisation and the switch from coal to oil demanded additional land and transhipment facilities. The dependency on overseas imports of raw materials and fuels led to a jump in the amount of bulk transport by sea. Seaport regions thus became privileged locations for seaport industrialisation. Seaport cities tried to exploit this development by planning and constructing outer ports, like in Bremerhaven for Bremen, Le Havre for Rouen and Warnemünde for Rostock.

Concurrently with the development of modern seaports, harbours and shipping were undergoing a process of musealisation (Hamburg International Harbour Preservation Symposium 1989). The first shipping museums were founded and film producers discovered the business potential of maritime nostalgia. The amusement districts formerly reserved for sailors changed in character.

The fourth phase is defined by the retreat of land uses from the traditional harbour areas near the city centre. The decline in importance of many ports was concurrent with the deindustrialisation of areas around the harbour. Many ports have lost their significance not only as places of transhipment and trade, but also as locations for seaport industries. Increasing international competition in shipbuilding and the decline of shipbuilding in Europe had a devastating effect. Production was relocated to Southeast Asia, which led to massive unemployment in almost all European shipbuilding locations and to the dereliction of shipyards in Europe and North America. The oil crisis, the decline in oil-tanker building, followed by an increase in the use of nuclear power, led to structural changes in the significant seaport cities economies. The trend towards the coast had only meant a short-lived location advantage and was displaced by a new stage in the international division of labour, which now favours the relocation of primary industries to countries rich in raw materials, such as Brazil, Morocco, Saudi Arabia, etc.

Most of all, this phase is characterised by changes in transport technologies (Witthöft 2000). The invention of the container by Malcom McLean heralded a new era of maritime traffic and for its ports: in 1966, the first container ship, the "Fairland", docked in Bremen. Containerisation revolutionalised dock labour and brought on the need for new transhipment sites and port facilities. The rationalisation of dock labour became possible with homogenised and standardised loading units; the container turned into a symbol of global trade. Initially dismissed as 
"containeritis" and rated as a fad, it brought in its wake the lasting transformation of seaport cities. The period of time a ship is berthed is no longer measured in days or weeks, but in hours. Entire fields of occupation are no longer needed in ports, like stevedores, lumpers, winchmen, tallymen. "Schaffte ein guter Hafenarbeiter im Jahr 1948 pro Schicht 5,4 Tonnen Warenumschlag, so bringt es sein heutiger Kollege auf 294 Tonnen" (Karstedt/Worm 1999: 61). The container revolution increased productivity manifold and brought with it dramatic job losses in the operative core sector of the port economy.

The fifth phase is characterised by the spatio-temporal concurrence of highly modern terminals away from the city, and by derelict and/or suboptimally used inner city harbours and waterfront sites. The waterfronts were often degraded by highways. The cranes of the shipbuilders' yards, which used to be a characteristic feature of the city silhouette and a symbol for dynamic port economies, have been dismantled, the land left derelict and contaminated.

From the 1960s on, seaport cities saw the increase of differentiation processes. Large container ships only call at a few main ports, while smaller harbours are supplied by feeder services. Hinterland, location advantage, sufficient depths for seafaring ships and accelerated transhipment ("only a sailing vessel makes money") have gained even greater importance as location factors. Passing locks and entering or exiting docks causes delay. In all ports of the world there are evident trends for the isolation/decoupling of transhipment on the one hand, and added value and employment on the other.

The type of work in ports has changed (de-casualisation) and often the port has moved seawards to a location away from the city centre. Containerisation and computerisation accelerated the rationalisation of transhipment and the spatial relocation of functions which used to be bound to the port. Seen in this context, the areas where port and city meet have undergone severe changes in land use, economic activity and in the built environment. The traditional port with its narrow fingerpiers, multi-purpose terminals and quayside warehouses could meet the new standards. Quayside storage and warehouses, sheds used for temporary storage protected from the weather, are no longer necessary.

The transhipment of containers to other means of transportation requires much larger areas of land. Good railway and road connections like motorway junctions are required for the rapid delivery and removal of containers in overland transport. The water side of container tran-

8 "A good docker handled 5.4 tons of goods in one shift in 1948, his present-day colleague now manages 294 tons." (Translation: Dirk Schubert) 
shipment requires fewer quays because of reduced berthing periods, but they have to be always available and of sufficient depth for seafaring ships (Bonz 2006: 40). The increase in containerisation means declining employment in transhipment, i.e. fewer dockworkers, but ever larger land areas, more costly infrastructure and the ever deeper - ecologically questionable - dredging of rivers and ports.

Meanwhile, we can identify a new cycle $-a$ sixth generation - of waterfront transformation and retransformation on a regional scale. Much experience in developing central urban waterfronts has been gained. Generally, transformation began in the oldest parts of the port and the city, slowly moving to more peripheral areas, which were developed later. Often this was done in a step-by-step approach, beginning with the most attractive sites, but not integrating these projects into a sustainable urban or regional development strategy. In order to define this process as a new cycle, it must be looked at in comparison, while complex problems need to be reflected on the macro, meso and micro levels. In the context of increasing competition between seaports and the challenges of globalisation, waterfront developments are being integrated into the city-wide and regional perspective.

\section{Waterfront revitalisation - stages and experiences in Europe, North America and Asia}

Hoyle's historical-analytical model can be extended into types of transformation processes in ports and on waterfronts. This permits the classification of phases and cycles of conversion, each in the context of the actual, local, regional and national constraints.

For several decades now, the restructuring of derelict docks and waterfronts in inner cities has been taking place on a world wide scale, from Antwerp to Zeebrügge, from Brisbane to Yokohama. The central waterfronts of these cities have since been changed considerably (Schubert 2002: 32). The reasons and problems of revitalising land formerly occupied by the port and port-related industries are similar in many seaports, but aims, planning cultures, financing and scale are very different in Europe, Asia and North America.

Discussion on suitable and sustainable strategies to deal with the potential of former port areas has led to controversial debates concerned with practical planning as well as theoretical issues, about aims and priorities. Despite the unique potential, considerable delays between dilapidation and renewal were common. The central waterfronts of these cities have since been changed significantly. Redundant and derelict port areas 
and waterfronts are one of the greatest challenges for town planners and offer a great opportunity on a medium to long-term basis for new uses like tourism, housing and offices, and for a reintegration into the urban fabric (Breen/Rigby 1996).

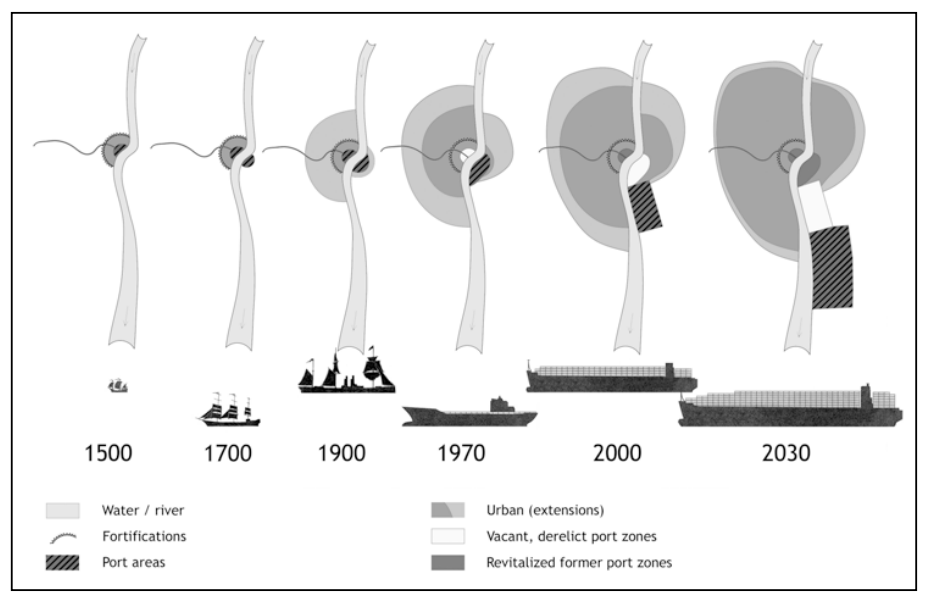

Fig. 2: Cycles of waterfront transformation (Dirk Schubert)

To simply copy a "successful" project and course of action cannot be recommended. Generalisations are difficult to make and easy recipes do not exist. Differences in cause, procedure, results and planning tradition need to be taken into account. It is not just a matter of architectural design, but of a complex set of planning, institutional, political, client-related, economic, ecological, legal and financial questions (Bruttomesso 1983). The process of transformation at the city-port interface follows a general cycle:

- dereliction of old port areas near the city, relocation of modern, containerised trading facilities to areas suitable for expansion, outside the city centre

- disuse, temporary and suboptimal utilisation of areas and buildings in the old ports

- visions and plans for the reallocation of uses of buildings and land in derelict areas, architectural competitions

- implementation of plans, establishment of new land uses (offices, recreation, housing) in these areas

- revitalisation, new land uses, acquisition, enhancement of desirability of these areas. 
The dereliction of these ports and waterfronts, often dramatised in Europe, is a "normal" process that will, at best, lead to rapid re-utilisation. In Germany and in Europe, the revitalisation of ports and waterfronts often takes years, if not decades, from the time of disuse to the start of reorganisation. In Asia, the continuous and rapid rebuilding of the waterfront seems to be the norm, often linked to land reclamation projects.

\section{Approaches in North America}

The first generation of waterfront revitalisation projects started in the mid-1960s in North American cities like Baltimore, Boston and San Francisco, where problems of derelict and underused port areas first became an issue. ${ }^{9}$ As these projects represented a new planning task, a "learning by doing" approach was often adopted. New uses frequently included tourist facilities, hotels and offices. At the time of dramatic changes due to containerisation in the early 1980s, more seaports engaged in projects of waterfront revitalisation. Large-scale projects of vast dimensions became the norm; a mix of offices and leisure facilities along the waterfronts was the prevailing approach. This happened in a period of deregulation, resulting in a "likeness" of many port cities. Like-minded architects, planners and developers dominated the scene and there was much criticism of the new "concrete curtains" along the waterfronts.

Baltimore's Inner Harbor became the most copied American effort of urban renewal and waterfront revitalisation. In Baltimore, the combination of a convention centre, hotel, sports facilities, aquarium and festival marketplace made up the specific ingredients. City marketing was another important issue, which exploited the success of waterfront revitalisation in the competition between cities. The strategy of "returning the shoreline to the people" was quite a successful part of the improvements to the downtown district. The project was based on a "shared risk" approach, splitting the responsibilities between the private and the public sectors. The thriving enhancement and commercialisation of the public space on Harborplace (Harvey 1990: 93) took place concurrently with the further decline of the adjacent city centre. ${ }^{10}$

9 A bibliography by the author including further references on the projects can be found at: http://www.tu-harburg.de/b/kuehn/themen/wfb.html.

10 The myth of the Baltimore model and the improvements around Harborplace is juxtaposed with a remarkably crisis-ridden urban reality (Ward, no date). 


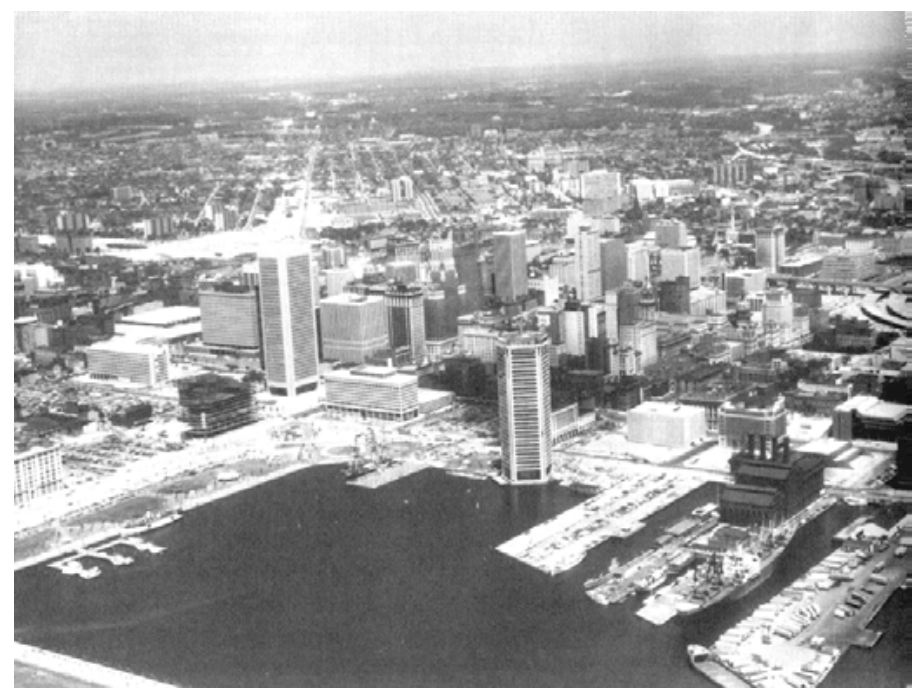

Fig. 3: Baltimore Harborplace (photo: Dirk Schubert)

Boston started with the conversion of two old buildings, Faneuil Hall and Quincy Market. They had originally been located on the waterfront, but are now far from the shoreline due to late $19^{\text {th }}$ century land reclamation projects. The buildings were reopened as a shopping mall in 1976. This was the starting point for relocating port facilities from the centre seawards, and a chance for revitalising the older piers. Condominiums, a hotel, an aquarium and offices were built. An elevated highway cut off the waterfront from the centre. This has been relocated in a tunnel in the meantime, and new public spaces connect the waterfront with the centre and the town hall. It was one of the most expensive infrastructure projects in the USA, which now offers new opportunities for the waterfront. The downtown waterfront was redeveloped and further projects have been started in the neighbouring seaport district. A large convention and exposition centre and a hotel were built along Northern Avenue to create the image of a "New Boston". North of the downtown area, in Charlestown, former shipyards have been converted to housing and a marina.

In Manhattan, New York, the former port facilities have been moved to New Jersey. In the early 1980 s, a strategy was developed to reuse some of the old finger-piers for leisure to give Manhattan a new face ("fun city"). South Street Seaport was opened in 1985; this was a huge success as it is located next to the downtown centre and Wall Street. In 1982, a survey was conducted on all waterfront areas in Manhattan, and a "New York Waterfront Revitalisation Programme" was created. This 
programme is a long-term vision, foreseeing public access to the waterfront, wherever possible. Some of the most interesting projects include Gantry Plaza State Park on the East River in Queens, where a railway ferry terminal was converted into a park. The Chelsea Piers Sports and Entertainment Complex (18 ${ }^{\text {th }}$ Street) is a project converting four old piers into a modern leisure facility. Of course, the rebuilding of the World Trade Center is most important for creating the new waterfront skyline of New York.

A "festival market" approach (nicknamed "Rousification"11) was often adopted, offering tourist-orientated shopping. This leisure-orientated type of revitalisation combined hotels, small shops, boutiques, restaurants and bars with public access to the waterfront (Breen/Rigby 1996). As these areas were frequently located next to the city centre, they successfully combined inner city and waterfront revitalisation. It is remarkable how the US American model successfully copies European port cities and idyllic market places, to then transfer these back to Europe and Asia - modified into a commercial US concept.

\section{Approaches in Europe}

At the beginning of the 1990s, a new generation of approaches emerged. In European seaport cities like Oslo, Rotterdam and Gothenburg, participatory planning became popular and the local community was involved in planning processes. Often a step-by-step approach involving design competitions and master plans was introduced, to lead the way in restructuring the former port areas. Events such as the Olympics (Barcelona) or culture and leisure facilities like aquariums and museums were frequently used to push redevelopment (Meyer 1999). At the beginning of the new millennium, a new generation of projects emerged. Private-public-partnerships and professional planning management dominated the global competition between waterfront revitalisation projects. These projects were used in new city-marketing strategies based on the unique seaport heritage. At that time (luxury) housing and mixed-use developments became more widespread.

In London, the oldest docks closed from the mid-1960s and shipbuilding declined. Within 20 years, the once largest port in the world failed to meet the new challenges in transport technology. But Margaret

11 Named after the developer James Rouse who was involved in similar festival markets in Sydney, Boston, New York, Norfolk, Santa Monica and Osaka (Olsen 2003: 240). 
Thatcher had a vision: Docklands - an exceptional place. She pursued a policy of free enterprise zones, the first to be established in the London Docklands. These zones were taxfree for ten years, non-unionised and without planning restrictions, free business for free entrepreneurs. The London Docklands was the first project of this type in Great Britain, and Margaret Thatcher herself called it the "flagship project". American examples like Baltimore and Boston provided general inspiration for the London Docklands, but regeneration was on a far larger scale $\left(22 \mathrm{~km}^{2}\right)$. It was mostly office-led redevelopment, although some luxury housing was also built. Canary Wharf was the flagship of the Thatcherite approach to planning (Edwards 1992). The centre at Canary Wharf was built to challenge the financial hub in the City of London, several miles upstream. The project was implemented in the period of a new enterprise culture based on privatisation, deregulation and marketisation of activities.

Canary Wharf was designed as the tallest building in Europe, and it was the largest European construction site at that time. New construction methods were used and within a short time the building was ready for occupancy. The free enterprise zone and the policy of the London Docklands Development Corporation (LDDC) left London with a fragmented city. New office developments and luxury housing were put up next to old blocks of public housing. New jobs were brought into the area, but not for the local people, leading to segregation and contradictions between old and new (Foster 1999). Since then, the Docklands project has been extended into the Thames Gateway strategy, including a much larger area stretching from London to the Channel. London is probably the most spectacular transformation of a former port in Europe.

The approach in the second phase in Europe was quite different from that in North America. Bilbao, a former river port with large shipyards, underwent culture-led redevelopment, using the success of the Guggenheim Museum ("El Guggi”) as a starting point for revitalisation. Two million visitors came to see the museum in the first two years after opening. Soon a greater area (Abandoibarra) along the River Nervion near the city centre was earmarked for redevelopment. The grey, dirty industrial town has changed into a post-modern city with a new metro. In the meantime, a shopping centre, housing, new hotels, a concert hall and a convention centre were also built in this area along the waterfront. The port and railway facilities have been relocated to the Bay of Biscay, even though there was no regional planning authority and many different authorities were involved in the process.

In Amsterdam, the approach was led by housing. A housing shortage in the inner city made people move to the outskirts, paying taxes there. 
In the Eastern Docklands only high-densitiy housing was built with some infrastructure. High-density housing was necessary because of the enormous investments gone into preparing the land for building and installing the infrastructure. The vision was to use water as a kind of green space ("blue is green"), although water areas could not be used by everyone, especially children. The redevelopment of the Eastern Docklands is the largest post-war building project in the heart of Amsterdam. By mixing luxury rented housing with public housing, municipal policymakers also hoped to end the exodus of higher income groups. The transformation of the Eastern Docklands into a residential area has now been implemented and further projects are planned in the Western Docklands and on the northern bank of the River Ij. The land opposite the city centre is occupied by shipyards and will be converted for mixeduse in a step-by-step development in the future. The long-term strategy of transformation includes temporary use by artists and students.

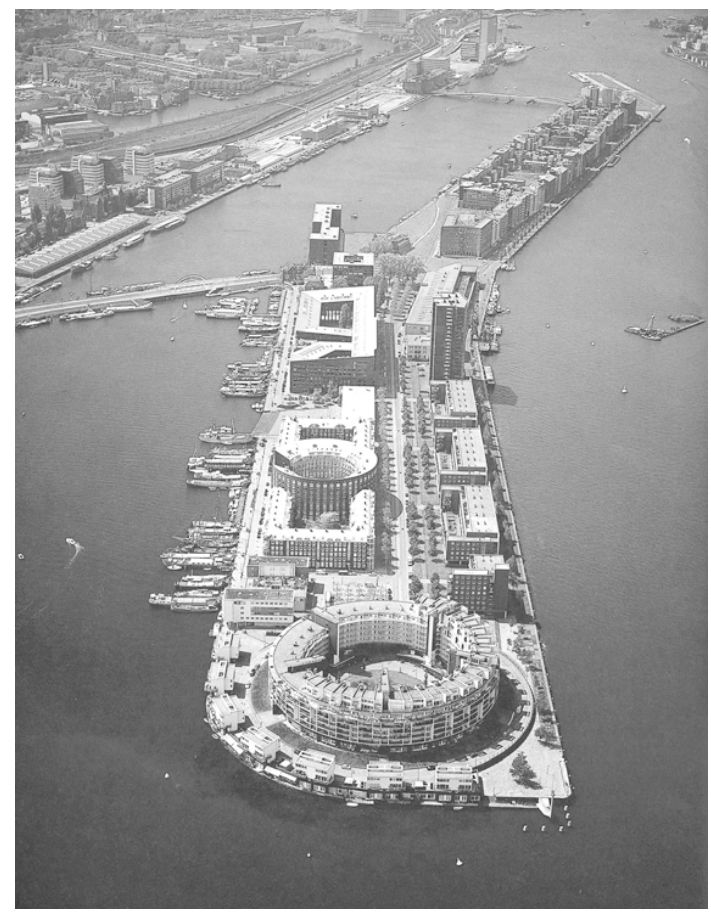

Fig. 4: KNSM Island-Eastern Docklands Amsterdam (photo: Dirk Schubert) 
In Hamburg, the HafenCity reconnects the River Elbe to the city centre, giving it a new direction of growth, down to and along the river. HafenCity is located next to the Warehouse District, extending to the bridges over the River Elbe. For the first time, a large area will be taken out of the port and put to other than port-related industrial uses. The borders and gates of the customs in the free port had to be relocated elsewhere in HafenCity. The area comprises approximately 155 ha; it has no inhabitants, but some old and some new operational port facilities. It is surrounded by several neglected housing estates, the city market, industrial and port facilities and railway lines. Hamburg has adopted a mixed-use approach for HafenCity. Following a competition for a master plan, specific districts were designed with a focus on offices, housing, shopping, recreation, etc. In a way, HafenCity is a latecomer project where planners tried to avoid the mistakes of other waterfront revitalisation projects. Approximately 5,500 apartments for 10,000 to 12,000 inhabitants are planned (Bodemann 2002: 102). Estimations of the required social infrastructure are based on these figures. The area is within the Elbe flood plain, making built and organisational solutions for the protection of people and buildings indispensable. The master plan guidelines determine the implementation of development, phased in sub-districts. It lays down a principle development sequence from west to east, avoiding uncontrolled construction activities throughout the development area. A zoning plan for the first phase of HafenCity was already drawn up in 2000, and land sales started in 2001. A development agency was established in 2002 and the first buildings completed by 2004. The newly founded GHS (Port Area Development Corporation, later HafenCity $\mathrm{GmbH}$ ) is responsible for this area and for the implementation of the projects. Most of the land is owned by the city-state of Hamburg.

\section{Approaches in Asia}

In Asia, history is systematically eradicated: everything is on the move, permanently. All port cities share the determination to rapidly adjust to the challenges of globalisation and to push the unparalleled reorganisation from former, insignificant colonial places into knowledge- and service-based centres, to subsequently emerge as important hubs in the world wide network of seaports. The continuous and rapid rebuilding of the waterfront seems to be the norm in Asia, often linked to land reclamation projects (Schubert 2006: 268).

In Singapore, there are major plans for the development of Downtown, located on the mouth of Singapore River. Around Marina Bay, a 
new centre is envisaged to strengthen the link to the waterfront, comprising offices, shops, cafes, hotels, promenades and nightlife ("Tropical City of Excellence") (Chang/Huang/Savage 2004: 418). The area, approximately 370 ha in size, was reclaimed by landfill. Proposals are for a floor space index of 0.7 and the flexible updating of the plan in response to future demands. The capacity of a Central Business District (CBD) can be extended by approximately $25 \%$. The aim is to develop an exceptional concept that mirrors the uniqueness of Singapore. The concept proposes to reinforce and extend the existing centre, create pedestrian zones and develop the waterfront skyline. The two largest projects of the revised Concept Plan 1991 - both on reclaimed land - are Marina South and Straits View to the south of the river's mouth, and Marina East to its north. Marina South lies to the west of the East Coast Central Highway and exceeds 100 ha in area. Marina East extends over an area of approximately 140 ha to the west, adjacent to the Downtown Core. The primary aim of the Downtown Core Plan is to foster water-related activities, links to the water and its accessibility. Singapore's strive to become a metropolis finds expression in the expansion of the city - a new city is built on man-made land, side-by-side with the "old" Downtown.

Shanghai is conducting a unique experiment in the construction of Pudong. The communist controlled economy is consenting to a capitalist island within the city of Shanghai on which a Chinese Manhattan is built in record time. The reform of the controlled economy is to be evolutionary, initially restricted to economic zones, following examples of development in other tiger states, such as Singapore and Hong Kong. Hence, Pudong is the experimental ground for the Chinese Policy of Opening according to a Chinese metaphor the dragon's head - that is of strategic importance for the economic development and the future of China. $\mathrm{Pu}$ dong will be a sparkling new city of superlatives, the Chinese version of synchronicity of capitalism and controlled economy. The neglected eastern bank of the Huangpu River and the triangular Pudong New Area comprise a total area of $570 \mathrm{~km}^{2}$, approximately $8.2 \%$ of the area of Shanghai - roughly equivalent to the area of West Berlin. The name $\mathrm{Pu}$ dong did not represent a specific administrative unit until recently, when it was chosen for the Special Economic Zone. Most of the area lies within a $15 \mathrm{~km}$ radius from the city centre. Pudong is bordered by water on three sides; its coastline is approximately $65 \mathrm{~km}$ in length. Planning and implementation of Pudong will be carried out over a 40-year period conducted in three phases (1990-1995, 1996-2000, 2000-2030). Pudong New Area occupied a central part in the ninth Chinese Five-Year Plan, 1990-1995. Central Government in Beijing allocated substantial funds and provided the legal framework. In 1993, the Pudong New Area Ad- 
ministration (Committee) was appointed to coordinate construction, infrastructure and social projects with a relatively high degree of administrative autonomy. The tenth Five-Year Plan expired in 2005 when most of the important infrastructure projects should have been completed.

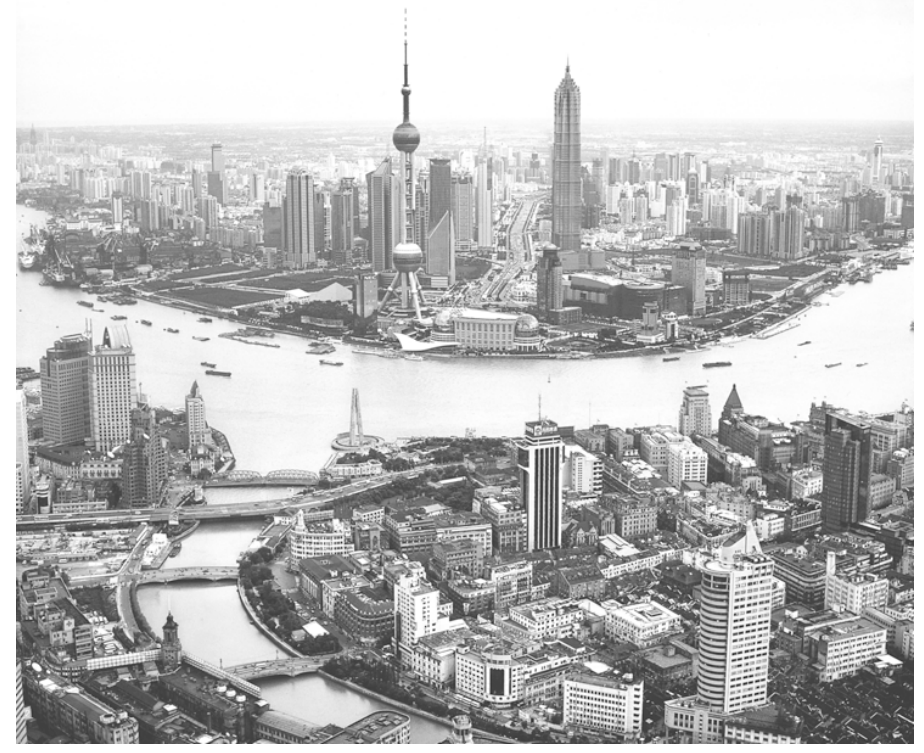

Fig. 5: Shanghai - Bund and Pudong (photo: Dirk Schubert)

In Japan, waterfront revitalisation is often combined with land reclamation. The most important examples of this strategy can be found in Osaka, Kobe, Tokyo and Yokohama. In all these cases, the ports moved seawards to provide deep-water access for the largest ships. As not enough land was available for the required new terminals it was created in reclamation measures to generate as many zones for deep-water access as possible. The artificial, new islands were constructed in the sea, with clearly defined zones often comprising a mix of housing (especially for dockers) and new container terminals. They are also sites for airports, power stations and sport stadiums, although port-uses are most relevant. The infrastructure connecting these artificial islands by bridges and tunnels is of course costly. As reclamation strategies are formulated for a long-term perspective much vacant land is available on the new port islands. Older, underused areas, derelict land and empty, old sheds and warehouses close to the city centres were converted into shopping malls or festival markets, often in combination with new hotels, muse- 
ums and aquariums. These projects are somewhat similar to the North American festival market approach and seem to be extremely popular in Japan, as people love shopping in these places: "shopping is fun".

\section{Summary}

Of course, the diverse approaches described above must be seen in the context of different regional/continental relationships. Of equal importance however are topographical factors, the local urban and port history, the network of stakeholders, governance structures and the diversity of planning cultures. As little comparative research has been done in this field so far, such studies are needed to offer a framework for identifying different structures of decision making processes, different types of urban development and diverse socio-cultural conditions. Inter-disciplinary work is a necessary precondition for this approach, and a more concentrated discussion between theory and practice is urgently required. The results of such research will illustrate revitalisation projects in derelict port areas and on waterfronts as seen from different angles and various discipline-specific approaches. Projects must be examined from the point of view of different stakeholders (planners, architects, port economists, researchers) and put into context of urban development politics. The diversity of contributions reflects the different analytical and planning approaches.

\begin{tabular}{|l|cc|}
\hline & \multicolumn{2}{|c|}{ Location } \\
& central & peripheral \\
\hline Railway lands & $\mathbf{x}$ & \\
Military conversion & & $\mathbf{x}$ \\
Industries & $\mathbf{x}$ & $\mathbf{x}$ \\
Mining & $\mathbf{x}$ & $\mathbf{x}$ \\
Markets/Slaughterhouses & $\mathbf{X}$ & \\
Port facilities & & \\
\hline
\end{tabular}

Fig. 6: Typology of brownfield sites (Dirk Schubert)

Redundant and derelict port areas and waterfronts are one of the greatest challenges for town planners and offer great opportunities on a mediumto long-term basis for new uses like tourism, housing and offices, and for the reintegration of these areas into the urban fabric (Priebs 1998). 
Waterfront transformations are part of brownfield regeneration, which also includes other derelict, contaminated, vacant, abandoned, previously developed, now under-used sites, development interests and stakeholders (Alker/Joy/Roberts/Smith 2000: 51). The typology shows some dimensions of brownfield sites important for transformation and regeneration. In this context port facilities and waterfronts are related to local urban port and cultural history with special opportunities for redevelopment.

A particular literary genre focuses on the (moral) history of the harbour.

"Der Charakter der Hafenstädte wird durch die Bedachtnahme auf die Fremden geprägt. Der Hafen ist der Umschlagplatz für fremdes, der Stadt exotisches Menschenmaterial, hier strömen die sorgenfrei neugierig Reisenden, die einer trostarmen Vergangenheit entfliehenden aus den Binnenländern zusammen, um - von Niemandem gekannt und im Gefühl der Lösung von ihrer alten Welt - in der Unrast vor langer Fahrt, hemmungslos Abschied zu feiern, sich auszuleben [...]. Hier findet der Seemann nach wochenlanger Reise das seinen aufgestauten Mannesbegierden und seiner gefüllten Börse willige Weib, hier ist das Neue, Farbige, Wechselnde, Fremde, das Keines Aufenthaltnehmenden Zuhause entspricht, in dem die Begierde jedes Einzelnen nach abenteuerlichem, neuartigen Erleben gestillt wird [...]."12 (Fischer 1927:13)

There was talk of the "horror and vice of prostitutes' districts in international ports" and the "agitated, unbridled in its desires, frantic life of port cities" was pleasurably described from the bourgeois voyeur's perspective. In this context, harbour areas can be understood as sites of strangers and diasporas (Kokot 2002: 95ff.) in which catch-up modernisation processes meet (ethnic) minorities in "backward" milieus.

Seaports have always occupied an important role in the economic and cultural life of nations. "The history of ports is, in great measure, the history of civilisation", wrote Morgan/Bird (1958: 150). Ports were, and still are, fascinating culmination point of the economy, society and cul-

12 "The character of port cities is defined by their concern for strangers. The harbour is the handling place for strange human material exotic to the city; here the carefree, curious travellers flock from the hinterland, who flee their disconsolate past. Unrecognised and in the spirit of disengagement from their old world, restless before long journeys, they want to celebrate without inhibition their farewell, to enjoy life [...]. This is where the sailor after weeks of travel finds the willing woman for his pent-up desire and filled purse, this is where the new, colourful, changing, alien is found, that is unlike the homes of those who seek shelter here, that satisfies the yearning for adventure and for a new experience [...]." (Translation: Dirk Schubert) 
ture, even though the port economy is diversifying and their significance tends to be decreasing. City on the waterfront, amphibian city, water's edge, gate to the world, contact to overseas, homesickness and yearning for faraway places are terms associated with ports. Crying and waving girls on the dockside are part of this romantic notion, which is evoked in books, films and songs. The redevelopment of the water's edge and the revitalisation of waterfronts offer a once in a century chance to let port and city, water and land, history, present-day and future merge in a new symbiosis.

\section{References}

Alker, Sandra/Joy, Victoria/Roberts, Peter/Smith, Nathan (2000): “The Definition of Brownfield". Journal of Environmental Planning and Management 43 (1), pp. 49-69.

Bodemann, Uwe $\left(2002^{2}\right)$ : "HafenCity Hamburg - Anlass, Masterplan, Chancen”. In: Dirk Schubert (ed.), Hafen- und Uferzonen im Wandel. Analysen und Planungen zur Revitalisierung der Waterfront in Hafenstädten, Berlin: Leue, pp. 99-117.

Bonz, Gunther (2006): “Die wirtschaftspolitische Bedeutung des Hafens für Hamburg”. In: Jahrbuch der Hafentechnischen Gesellschaft, Vol. 55, Hamburg, pp. 39-42.

Borscheid, Peter (2004): Das Tempo-Virus. Eine Kulturgeschichte der Beschleunigung, Frankfurt am Main et al: Campus.

Breen, Ann/Rigby, Dick (1996): The New Waterfront - A Worldwide Urban Success Story, London: Thames and Hudson.

Brenner, Neil (1997): “Globalisierung und Reterritorialisierung: Städte, Staaten und die Politik der räumlichen Redimensionierung im heutigen Europa". WeltTrends 17, pp. 7-30.

Bruttomesso, Rinio (ed.) (1983): Waterfront - a new urban frontier, Venice.

Edwards, Brian (1992): London Docklands - Urban Design in an Age of Deregulation, Oxford et al: Butterworth Architecture.

FHH (ed.) (2005): Behörde für Wirtschaft und Arbeit, Hamburg Port Authority, Im Fokus dynamischer Wachstumsmärkte. Chancen und Entwicklungspotenziale des Hamburger Hafens, Hamburg.

Chang, T. C./Huang, Shirlina/Savage, Victor R. (2004): “On the Waterfront: Globalization and Urbanization in Singapore". Urban Geography 25, pp. 413-436. 
Christiansen, Flemming (2003): Chinatown Europe. Identity of the European Chinese towards the Beginning of the twenty-first Century, London et al.: Routledge.

Fischer, H. Erasmus (1927): "Sittengeschichte des Hafens und der Reise”. In: Leo Schidrowitz (ed.), Sittengeschichte der Kulturwelt und ihrer Entwicklung. Sittengeschichte des Hafens und der Reise, Vienna: Verlag für Kulturforschung.

Foster, Janet (1999): Docklands. Cultures in Conflict, Worlds in Collision, London et al.: UCL-Press.

GHS (ed.) (2000): Reihe Arbeitshefte zur HafenCity, Der Masterplan, Hamburg.

Harvey, David (1990): The Condition of Postmodernity. An Enquiry into the Origins of Cultural Change, Malden: Blackwell.

Heimerdinger, Timo (2005): Der Seemann. Ein Berufsstand und seine kulturelle Inszenierung (1844-2003), Cologne/Weimar/Vienna: Böhlau.

Hoyle, Brian S. (1989): “The Port-City-Interface: Trends, Problems and Examples". Geoforum 4, pp. 429-435.

Hugill, Stan (1967): Sailortown, London/New York: Routledge \& Kegan Paul.

Internationales Hamburger Hafendenkmalpflege-Symposion, 6.-9. September 1989 (1992): Industriekultur und Arbeitswelt an der Wasserkante. Zum Umgang mit Zeugnissen der Hafen- und Schifffahrtsgeschichte, Hamburg: Christians.

Karstedt, Claudia/Worm, Thomas (1999): "Container: Seekisten auf Landgang”. mare. Die Zeitschrift der Meere 12, pp. 58-65.

Kokot, W. (2002): "Diaspora und transnationale Verflechtungen". In: Brigitta Hauser-Schäublin/Ulrich Braukämper (eds.), Ethnologie der Globalisierung. Perspektiven kultureller Verflechtung, Berlin: Reimer, pp. 95-110.

Kossak, Egbert/Markovic, Mirjana (1989): Hamburg, Stadt im Fluss, Baubehörde, FHH, Hamburg: Ellert und Richter.

Läpple, Dieter (1994): "Hafenwirtschaft". Handwörterbuch der Raumforschung und Raumordnung, Hanover: Akademie für Raumforschung und Landesplanung, pp. 462-467.

Löbe, Karl (1979): Metropolen der Meere. Entwicklung und Bedeutung großer Seehäfen, Düsseldorf/Vienna: Econ Verlag.

Maak, Karin (1985): Die Speicherstadt im Hamburger Freihafen, Hamburg: Christians.

Meyer, Han (1999): City and Port. Urban Planning as a Cultural Venture in London, Barcelona, New York and Rotterdam, Utrecht: International Books. 
Miller, Raymond Charles (1969): "The Dockworker Subculture and Some Problems in Cross-Cultural and Cross-Time Generalizations". Comparative Studies in Society and History 11 (3), pp. 302-314.

Morgan, Frederick W./Bird, James. (1958): Ports and Harbours, London: Hutchinson University Library.

Neumann, Uwe (1997): Auswirkungen und Prozessabläufe der Erneuerung innerstädtischer Hafengebiete im Revitalisierungsprozess britischer Städte, Düsseldorf: Geographisches Institut der HeinrichHeine-Universität.

Olsen, Joshua (2003): Better Places Better Lives. A Biography of James Rouse, Washington, DC: ULI - the Urban Land Institute.

Osterhammel, Jürgen/Petersen, Niels P. (2003): Geschichte der Globalisierung, Dimensionen, Prozesse, Epochen, Munich: Beck.

Phillips, Gordon,/Whiteside, Noel (1985): Casual Labour. The Unemployment Question in the Port Transport Industry 1988-1970, Oxford: Clarendon Press.

Priebs, Axel (1998): "Hafen und Stadt. Nutzungswandel und Revitalisierung alter Häfen als Herausforderung für Stadtentwicklung und Stadtgeographie". Geographische Zeitschrift 1, pp. 16-30.

Rudolph, Wolfgang (1979): Die Hafenstadt. Eine maritime Kulturgeschichte, Erfurt: Edition Leipzig.

Schubert, Dirk/Harms, Hans (1993): Wohnen am Hafen. Leben und Arbeiten an der Wasserkante; Stadtgeschichte. Gegenwart. Zukunft. Das Beispiel Hamburg, Hamburg: VSH-Verlag.

Schubert, Dirk (ed.) $\left(2002^{2}\right)$ : Hafen- und Uferzonen im Wandel. Analysen und Planungen zur Revitalisierung der Waterfront in Hafenstädten, Berlin: Leue.

Schubert, Dirk (2007a): “'Ever-Changing Waterfronts': Urban Development and Transformation Processes in Ports and Waterfront Zones in Singapore, Hong Kong and Shanghai”. In: Arndt Graf/Chua Beng Huat (eds.), Port Cities. Asian and European Transformations, Oxford.

Schubert, Dirk (2007b): "Transformationsprozesse an Hafen- und Uferzonen in Hamburg zwischen Containerboom und Anforderungen der Stadtentwicklung”. Neues Archiv für Niedersachsen 1, pp. 56-79.

Ward, Stephen (no date): The Globalisation of the Baltimore Model of Waterfront Development: A Case Study of Developer as Agent of Transnational Diffusion (svward@brookes.ac.uk).

Witthöft, Hans Jürgen (2000): Container: eine Kiste macht Revolution, Hamburg: Koehler. 


\section{Notions on Community, Locality and Changing Space in the Dublin Docklands}

ASTRID WONNEBERGER

Dublin's Docklands have undergone significant changes since the beginning of regeneration in the late 1980s. New apartments and offices have taken the place of former warehouses, dock-related industrial sites, coal and timber yards. Today, the renovated "campshires" (the land between the river and the road), characterised by thriving dock activities in the past, invite tourists, office workers and local residents for walks and coffee breaks. The population of the area has increased by $11.8 \%$, from 17,425 residents in 1996 to 19,467 in 2002 (DDDA Master Plan 2003:14). ${ }^{1}$

However, not everybody considers the rejuvenation of the docklands in all aspects as positive as promoted in the brochures. Although the local communities living in the area for generations are explicitly considered in the regeneration plans, the fundamental changes in what they perceive as their traditional territory, have caused a number of conflicts with city planners and investors. Surrounded by new wealth, modern apartments and large numbers of new residents, the residents of the oldestablished neighbourhoods feel excluded and fight for their share in this

1 The figures are somewhat contradictory, as the ESRI (1996: 10) speaks of 16,713 residents in their study of 1996 , which served to prepare the rejuvenation plan of the docklands. In their Master Plan Monitoring Report 2004, the DDDA finds 19,704 people living in the dockland area, which would mean an increase of $13 \%$ since 1996. In the meantime, the numbers of residents have further increased by thousands of people, particularly since the opening of the huge new apartment complexes around the Grand Canal Basin, the Gasworks/Barrow Street and a few other areas in 2005 and 2006 (see also DDDA News, 09/01/2007). Updated statistics have not been published yet. 
redevelopment process and against plans which they perceive as harmful to their community structure.

The future of a "dockland culture", dockland identities and functioning communities are at the centre of this debate. Today as in the past, the dockland neighbourhoods are characterised by a very close social structure, which is based on kinship ties, friendship, face-to-face interaction on a daily basis, communal events and meeting points. Particularly important is a strong sense of territory and communal boundaries. The physical urban space, however, is now undergoing dramatic changes on a variety of levels. High-rise apartment blocks overshadow the traditional cottage-style housing of working-class residents, old dock-related buildings and landmarks are demolished or renovated and attached with new meanings, public space is privatised and new roads or bridges cross old boundaries or create new borders.

This article analyses specific examples of urban transformation in the Dublin docklands and explores the consequences of physical change in urban places and spaces on the structure of the dockland communities. While some of these effects are welcomed, if they benefit the entire community or parts of it, others are strongly opposed, particularly if the residents see their close-knit and functioning community structure threatened. New administrative boundaries for instance, exclude some residents from certain financial benefits. New bridges and roads create new gaps within communities. The demolition of old-port-related industries, often with memories attached, is perceived as the destruction of markers for local identity in dockland communities. The new style of architecture shares no resemblance with what local residents regard as their cultural heritage. In some cases it even changes cultural behaviour, as the examples of the old-style communal balconies and new gated common space will demonstrate.

The following examples show that the dockland regeneration in Dublin is not just a dramatic change of the urban environment. The transformation of the physical landscape also has a significant impact on dockland culture, community structure, identities and residents' every day lives.

Based on ethnographic fieldwork in Dublin between 2002 and 2007, this case study analyses the complex interrelation between urban space and place, community structure and identity formation in the context of dockland transformation. The results presented in this article are part of a long-term social anthropological research project, which analyses the consequences of dockland regeneration on the micro-level. More than 100 residents, community leaders and experts were interviewed in the 
course of this research. To protect their anonymity, they will be referred to by numbers in this article.

\section{Changing space}

Concepts of space, place and territory have been heavily debated in social sciences in the recent past. In Social Anthropology, the close connection between a specific territory and a specific culture has been taken for granted for a long time. Facing transnationalism and globalisation, however, this position had to be reconsidered. Studies of diasporic communities, transnational identity formation and networks show that the assumed one-to-one relation between territory, culture, community and identity is not a naturally given fact. The concept of space is more and more distinguished from a physical territory and rather perceived as an abstract term. ${ }^{2}$

Some anthropologists have shifted away from territory-based fieldwork and rather focus on social networks (e.g. Gupta/Ferguson 1997; Hastrup/Fog Olwig 1997), others reconsider the old notions of space and culture, which receive new meanings in the context of new nationalisms, and call for studies on global processes and their impact on the local level (e.g. Hannerz 1996). It has become obvious that space, specific places and people's relationship with their physical environment are important aspects for behaviour.

Despite many debates, the terms "territory", "space" and "place" have not been unanimously defined yet. In order to avoid ambiguous meanings, I will use the terms in the following sense, fully aware that this does not mean an end of the general debate.

By "place" I refer to a specific (urban) physical location. This might be a public house, a building, a park or street etc. "Space" in contrast is more abstract. It is multi-dimensional and can be socially or culturally defined. Specific places can thus be part of various spaces. The "urban landscape" consists of physical features of land, including buildings, roads, bridges, waterways, but also fauna and flora. Finally, I use "territory" as an area that a group - in this context dockland communities perceive as their own, not necessarily on a legal basis, but in the sense that they have inhabited and used this area for generations and therefore regard it as part of their culture. ${ }^{3}$

2 On the discussion of space and place see in detail Hauser-Schäublin/Dickhardt 2003; Rolshoven 2003; Tomforde 2006; Appadurai 1991.

3 See for instance Rolshoven 2003: 208-210 and Haller 1994 for similar definitions. 
The Dublin Docklands, as an urban area in the centre of global transformation processes, are a good case to study this problem. Since the beginning of the port activities, the dockland area has never been only an industrial site. About six port-related communities ${ }^{4}$ have lived and worked in the area for generations and developed a specific relationship with the urban space around them. However, this space has been changing dramatically since the 1960 s.

The worldwide introduction of containerisation and new technologies have shifted the working port away from the inner city of Dublin and moved it to the seafront east of East Wall. ${ }^{5}$ Vast areas along the former port site, including warehouses, cranes, the quays, moorings and berthing docks, were no longer needed and fell into dereliction. Manual forms of labour became obsolete. The communities, who had been dependent on labour intensive work on the docks, experienced widespread unemployment and became increasingly dependent on social welfare. Due to rising crime rates and the introduction of drugs in Dublin's inner city communities in the $1980 \mathrm{~s}$, the docklands, particularly the areas around Pearse Street and Sheriff Street, developed a reputation as two of Dublin's most notorious "no go" areas. ${ }^{6}$

Facing the decline of the dockland area, unemployment, deprivation and instability, the regeneration of the docklands began in 1986 with the foundation of the Custom House Docks Development Authority (CHDDA). Under the Urban Renewal Act of 1987, the project aimed at redeveloping a small area of eleven hectares east of the Old Custom House, which was turned into a modern International Financial Services Centre (IFSC). This centre attracted Irish and foreign banks and other finance companies. $75,000 \mathrm{~m}^{2}$ of the former coal yard were rebuilt as office space, retail and leisure facilities, such as restaurants and bars, hotels and luxury apartments around the derelict George's Dock and the Inner Dock (Malone 1993, 1996; Buchel/Hogersvorst 1997: 58-65).

However, the development of the Custom House Docks site was only the beginning of the redevelopment of the entire dockland area. In 1997 the Dublin Docklands Development Authority (DDDA) was set up to secure "the social and economic regeneration of the Dublin Docklands Area on a sustainable basis" and to improve "the physical environment" (DDDA Master Plan 1997: 2) of the 1,300 acre site that cov-

4 On the definition of community in general and "dockland community" in particular see section "Community and territory".

5 For a detailed history of the port of Dublin see Gilligan 1989².

6 See for instance DDDA Master Plan 1997: 32 and statements by dockland residents, e.g. C3, C44, C66, C35, C36, C19, C52, or port workers and historians (C34, C72, C28). 
ers almost the entire former port area including five of the former dock communities. The development period was projected from 1997 to 2012 . Along with the physical regeneration an image change is intended (Wonneberger 2005), from the old working-class, and later run-down image of the area, to a new "world-class city quarter" (DDDA Master Plan 2003: 3).

Due to this plan, the entire area is currently under construction. Apart from a few listed buildings, the old warehouses, flats, docks buildings, factories and industrial features have been or are being demolished to give way to new housing $(20 \%$ of which has to be social and affordable), to hotels, retail outlets, offices, amenities (campshires, parks), tourist attractions and new transport infrastructure. The plans also include the local residents. In order to tackle the most urgent problems of the area, the DDDA offers and supports training and education programmes, work schemes, social and affordable housing and other initiatives for the local communities (DDDA Master Plan 1997: 23-40; DDDA 2003, 2005). In order to guarantee a high level of participation from the local communities, five representatives were taken on board in the so-called Community Liaison Committee (DDDA Master Plan 1997: 3).

The fundamental changes of the physical and social space of the docklands have caused debates within the dockland communities. Experiencing the consequences of long-term unemployment, deprivation, stigmatisation and feeling neglected by the state, the regeneration of their living quarter is generally welcomed by the residents of the local communities. However, surrounded by building sites that seem to change the area almost over night, dozens of new apartment blocks, offices, banks and obvious wealth, the communities feel at the same time excluded from many of these new developments and look very sceptically at some of the plans. After a series of protest marches and demonstrations, and due to the initiative of local politicians and community leaders, some of the high rise plans were sent back to the planning board to be revised. ${ }^{7}$

7 The protest by the dockland communities, particularly in North Wall, against the proposed 17-storey National Conference Centre in Spencer Dock was a permanent topic in the Dublin newspapers between 1998 and 2000. The Irish Times alone published over 150 articles on that issue until July 2000, when Bord Pleanála, the Irish planning board, rejected the original high-rise plan (Haughey 14/07/2004). The case triggered a huge debate about Dublin's future as a high-rise city in general, which is still not completed. See a summary of the entire topic in McDonald 2000a. 
Despite this success, the area is still transformed drastically including more high-rise buildings than ever before. Facing all these physical changes, people fear severe consequences for the area, their culture and particularly the functioning community structures. In order to fully understand the residents' relationship with their urban environment, a closer look at the history and present situation of the dockland area will be taken in the next section.

\section{Community and territory}

Apart from the fishing villages of Ringsend and Irishtown, which have been inhabited since the Middle Ages (DeCourcy 1996: 202, 325), the area now defined as the "docklands" was populated in the $18^{\text {th }}$ century, when the first dock workers followed the port downriver and moved into the newly developed residential areas around North Wall, East Wall and Pearse Street (Gilligan 1989²: 62-63; Byrne 2001: 12-25; DeCourcy 1996: 268-270). Originally based on the new parish boundaries, several communities developed over the centuries, each of which formed a specific communal identity and boundaries that persist until today.

Before introducing more ethnographic details, the term "community" has to be elucidated in this context. ${ }^{8}$ Over the years, anthropological approaches identified a number of features that characterise community as a specific type of social group. Among these features are a "relatively small population with close social ties, enduring over several generations", distinct boundaries, cultural homogeneity, common interests, and a certain self-sufficiency (Winthrop 1991: 41). Later approaches focused their attention on boundaries and identity formation (Barth 1969) or the symbolic dimension of community formation (Cohen 1985). The debate about the role of localities, territories, space

8 As Nigel Rapport points out, "the concept of community has been one of the widest and most frequently used in social sciences" (Rapport $1998^{3}$ [1996]: 116), and yet there is still no precise definition of the term. As early as 1955, Hillery identified over 90 different definitions (Rapport $1998^{3}$ [1996]: 114-117), the broadest of which refers to any group or persons united by common interests. In this meaning of the term, a professional group, a village or a club may be referred to as a community as well as an association or an urban neighbourhood (Seymour-Smith 1986: 46, Winthrop 1991: 41). Attempts to narrow this definition down have been numerous. A more detailed presentation of this debate would lead too far in this context. What is important here is to take a more detailed look at the situation in Dublin. 
and place in this context, which has been mentioned before, was a further extension of this concept.

Up to today, the term community is widely used in the Dublin context. The connotations of the term vary within different situations and range from very generalised meanings, which describe the entire population of Dublin as "the community", to more narrow ones which only include the residents of one particular street or social housing complex. Nevertheless, the most common usage of the term refers to the residents of a certain city quarter, such as "Pearse Street community" or "the community of Ballymun" with specific features, which parallel anthropological notions of the term. Life in the dockland communities is characterised by a very close social structure based on kinship and friendship. Neighbours know each other well and often over generations. People greet each other on the street; local pubs serve as regular meeting points, where every stranger is noticed immediately. Community festivals, community centres, local newspapers and - less than in the past but still to a certain extent - the parish church play significant roles in maintaining the close social structure. "Community spirit", a sense of community and functioning communal networks are viewed as political goals for the future. Their history as dockland communities, whose life depended on the dock economies, serves as a common marker of identification today.

Members of these communities also often speak of their "culture" in this context. While their usage of this term remains mostly vague, it can be specified from an anthropological perspective. Dockland culture includes a specific form of economy, which in the past can be called "urban subsistence" (Wonneberger 2006), values and belief systems, such as the importance of a close social structure and a common sense of history, which is based predominantly on the dock activities and thus distinguishes this area from every other Dublin neighbourhood. Further features include common patterns of behaviour and a shared relationship with the urban environment they live in, as we will see later. In this sense, I will use the term "dockland culture" in this article.

Since the 1980s, a new element was added to the concept of community: political action in order to gain power, resources and a voice in local politics, and to improve the economic and social situation of the residents. A newly formed unity of the residents of inner city communities directed against the drug problems of the 1980s strengthened the internal structure of these neighbourhoods. Since then, community lead-

9 See for instance the slogan "serving the entire community", which can be found on vehicles of Dublin Bus company. 
ers, organisations and local politicians have increasingly worked together and established quarter-based communities as important actors within Dublin politics. In this context, a community can also act as a corporate actor, in the sense that its members are represented by few community leaders in political action. The dockland communities, with their representatives on board the DDDA and their general characteristics, are a prototypical example for Dublin urban communities.

The physical space, the urban quarter where today's residents and their ancestors have been living for generations, plays a key role in this context. In the past, old industrial landmarks such as the gasometer on Sir John Rogerson's Quay or the Hammond Lane Foundry, gained significance through their economic meaning for the people who worked there. Even after these structures have been demolished - some of them as early as the late 1980 s or early 1990 s - they are remembered well. Local people, even young people who were little children when these buildings were demolished, still talk about them or use them to describe the area. When old places are renamed, such as the Grand Canal Dock site or Longboat Quay, as they are called by the DDDA today, long-term residents of the neighbourhood still remember them as "the Gas company site" or "Hanover Quay" and refuse to use the new names:

"I know that they want to promote the Viking heritage in Dublin, but why rename the streets here [in the dockland area]? Because the new posh apartments won't sell if they are still called Hanover Quay? They should keep the old name, particularly because the quays here were never the area the Vikings settled in. They lived further west. At that time in fact this area was still part of the sea." (C44, similar statements by C85c)

After the transfer of the docks and their industries, derelict sites were in some cases still used by the local residents. Examples include the dock basins, such as George's Dock on the north side or the Grand Canal Dock on the south side. Though illegally, the basins were (and sometimes still are) frequently used by children for swimming and therefore considered their territory and playground. When strangers moved in, in this case the Viking Splash Tours ${ }^{10}$, they felt intruded, disregarded and threatened. They "welcomed" the vehicles by throwing stones, and vandalism became frequent. Community leaders solved the problem by making a deal with the company:

10 The Viking Splash is a Dublin sightseeing tour with aquatic vehicles. Their route includes the Grand Canal Basin. 
"[The owners of the company] came and spoke to us and said, 'What can we do?' So we advised them, 'You are invading their territory, our territory. We are not interfering with you, you are interfering with us. Now do something about this. Get to know us, get us to know you and get us to like you and we will like you if you take part in what's going on here.' And it worked. [They got regularly involved in the annual South Dock (Community) Festival]. I am not saying that they never get someone throwing stones at them, but there is an acceptance of them." (C3)

Today, children can still be seen in the summer swimming in the Grand Canal Dock Basin, a section of which is also officially used for other water sports activities. On the north side, the construction of the IFSC has put an end to the swimming activities in George's Dock. Security guards chased local kids away, until the entire basin was finally filled in to $750 \mathrm{~mm}$ below the former water level. This low water level does not allow further activities. ${ }^{11}$

All these examples show how much the local communities feel connected to the urban quarter they live in. The local dockland landscape is perceived as part of their history and culture, and they feel rooted in this space, which they perceive as their own territory. This also means that they consider themselves entitled to access and to use the resources that are there.

As the following statements illustrate, many residents are very concerned about the demolition of many of the old buildings that they regard as reminiscences of their past and culture. They would like to see them preserved, rather than replaced by a new "concrete jungle" (C5b):

"I liked the old buildings. I don't like the glass buildings. They are very futuristic and I don't think they resonate so much with the community, with the past and the heritage. [...] I would have preferred if it was kept. Some, not all, but some sense of the history there, even the old building on the bottom and something else on the top. Just that there is a sense of it. I think you lose the sense of the docks with it. [The new glass buildings] seem out of place." (C69)

“The prospectors and developers don't give a damn about nostalgia or anything concerning the past. They pull down a house that had maybe the greatest

$11 \mathrm{C} 44, \mathrm{C} 30 \mathrm{~b}, \mathrm{C} 35$ and own observations 2002. While local residents are convinced that the basin was only filled in because the DDDA does not want local children to play or hang around in the IFSC (C30b, C35, C44), the official reason to fill in the basin was for safety reasons (oral statement by DDDA employee, August 2003). An additional concrete base was constructed to enable staging to facilitate events in the centre of the dock (DDDA June 2003: 5). 
bit of history attached to it and they wouldn't think twice of it. And it is gone." (C81c)

"In Princess Street, for instance, there is this big glass thing. It has no meaning whatsoever. No resemblance of the community, no resemblance of businesses that used to be here. It is just a big cold glass place. And it was a lovely place down there. They should have kept some facades so that we kept a bit of our heritage. We are losing our heritage more and more. The gasometer in Ringsend $^{12}$ is absolutely brilliant. It is brilliant the way they did that. But everything else is getting thrown out." $(\mathrm{C} 87)^{13}$

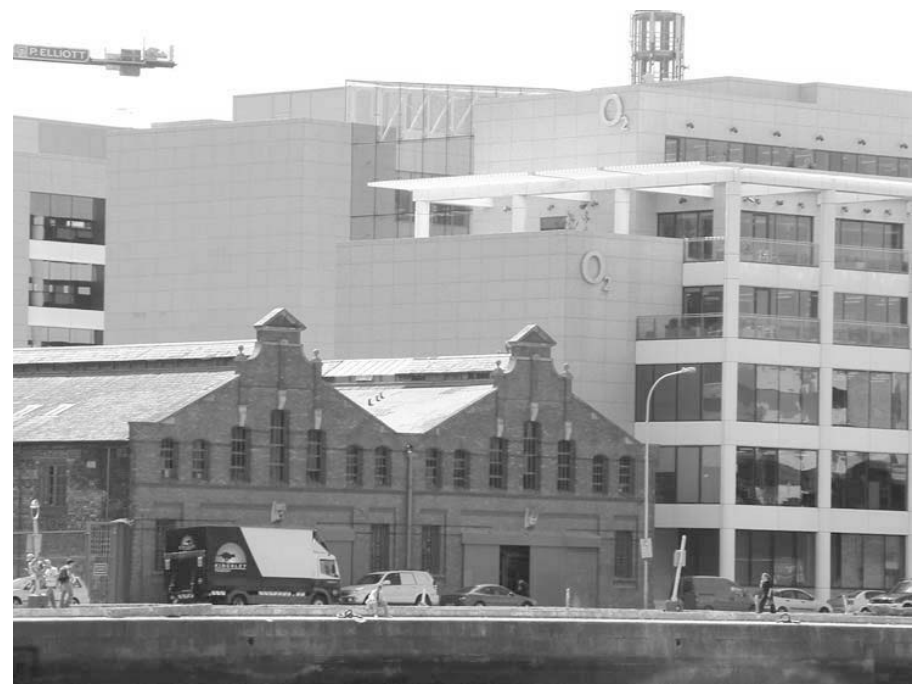

Fig. 1: Old and new architecture (Sir John Rogerson's Quay) (photo: Astrid Wonneberger)

The concern of the residents about losing their past, culture and identity with the demolition of old dock-related buildings and structures, and their attempts to preserve as much as possible, have been the topic of another article (Wonneberger 2005) and will not be analysed further here. However, apart from the symbolic meanings of the old landscape for a communal identity, the physical changes have a fundamental im-

12 The gasometer in the former gas company in Barrow Street was converted into apartments. The old iron structure was thus preserved.

13 These statements were no exceptions but express a very common attitude towards the new style of architecture in the docklands among community members. Other examples are C5b, C52, C44, C80a, C80b, C85d, C85c, C30b, C114, C79e. 
pact on life and culture in the dockland area. The following examples will illustrate how transformations of the physical space influence people's daily lives and, even more importantly, the community structure and identities of the indigenous dockland communities.

\section{New administrative and physical boundaries}

One consequence of the transformation of the docklands is the creation of new boundaries, both on a physical/traffic-related, and on an administrative level. While the former is directly connected to the construction of new bridges and roads in the area as part of the Master Plan, the latter is based on the foundation of the DDDA itself, and on the designation of a specific area as "the docklands".

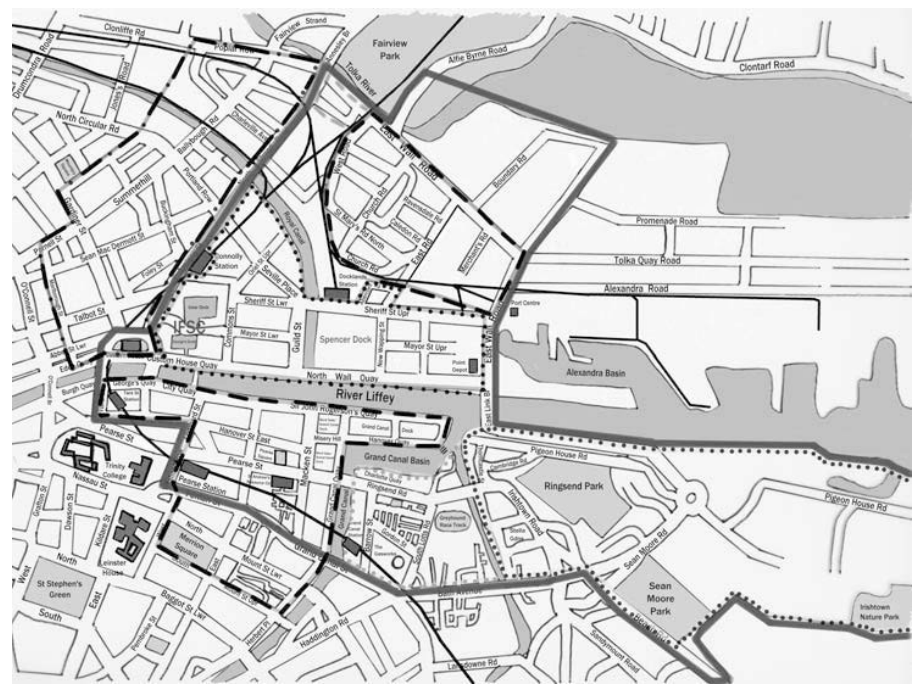

Fig. 2: Map of the dockland area and boundaries: DDDA (solid line), Westland Row/City Quay (Pearse St area) (dashed line, south side of the Liffey), Ringsend/Irishtown (dotted line, south side), East Wall (dashed line, north side), North Wall (dotted line, north side), North Inner City communities (combined Lourdes parish/Sean Mac Dermott St, North William St/Ballybough) (mixed line, north side) (Astrid Wonneberger)

Based on three preparatory studies, the Ministry for the Environment and Local Government established the DDDA in 1997. The subsequent Master Plan, which was adopted half a year later, comprises an area of 
526 hectares (DDDA Master Plan 1997: 2, 14-15), which "is broadly made up of five residential communities" (DDDA Master Plan 1997: 2), who used to be dependent on dock work in the past. However, the new boundary marked on the drawing-board does not include all port-related communities. Parts of the north inner city (NIC) are left out, even though a good number of their residents also worked on the docks and identify themselves with a dock-related past and heritage. ${ }^{14}$ Also, social networks have always connected all parts of the north inner city, so excluding this area does not make any sense on a cultural and social level.

Even if on the south side the dockland boundary does not leave out a specific port-related community, it does not correspond with the perceived community boundary of the Pearse Street area. It rather cuts right through the community. The dockland boundary is therefore an artificial boundary that includes most dock-related areas, but is not based on the historical dockside and perceived community territories.

If the marking of this new boundary on the city map, along with other administrative borders such as wards, city administration, parishes etc., had no practical consequences for the communities, it would probably have remained unnoticed by the residents and it would not have caused any problems or protest. As it is however, belonging or not belonging to the dockland area does make a difference on several levels.

One essential ingredient of the Master Plan is "the social and economic regeneration of local communities" and the "need for regeneration to include community participation in local development in order to counteract social exclusion" (DDDA Master Plan 1997: 27). Other issues concerning the communities are housing, play areas, traffic and public transport, employment and education, childcare, drugs and crime, all of which are to be dealt with as part of the dockland renewal and regeneration (DDDA Master Plan 1997: 28-29). In other words: there is a lot of money to be provided for the communities within the dockland area - but not beyond.

This caused much resentment and protest among community organisations and leaders in the north inner city. Watching the neighbouring communities, who were struggling with the same problems, receiving funds for community centres, job initiatives or playgrounds, the north inner city community demanded their equal share. Finally they were

14 See for instance the heritage publications by the North Inner City Folklore Project, Terry Fagan and Ben Savage, who do not draw a clear boundary between the North Wall and adjacent areas in their publications. The close ties between the North Wall and neighbouring areas also become obvious in the life stories that are told in these publications. 
recognised as the so-called "hinterland" and are now also eligible for schemes provided by the DDD (C19 [community leader NIC]).

On the other side of the river Liffey, similar cases happened with residents living on the south side of Hogan Place/Grand Canal Street, which is the south boundary of the dockland area. The houses on the south side are therefore outside the dockland boundaries, and the residents were originally not eligible for dockland funding and schemes. In one particular case, a young woman from Hogan Place applied for a student grant and was refused on the grounds that she lived outside the dockland area. She went to her local representative and they both protested against the decision. In the end her case was reconsidered and she received the grant $(\mathrm{C} 69, \mathrm{C} 87)$.

These two examples show that the designation of new boundaries, even though they only exist on a map, can have huge impact on the daily lives of communities and individuals. They can also cause resentment and envy between communities, rather than bringing them closer together. However, in both cases the DDDA had to acknowledge the fact that a clear cut boundary does not help to overcome social exclusion but causes new problems. For this reason, they reconsidered the plans and finally included all dock-related communities and individuals in their schemes.

However, not all consequences of physical regeneration can be handled that easily. Whereas the DDDA boundary only exists on the maps and can therefore be revised without difficulty, the regeneration process also includes massive physical transformations of the area. The improvement of the infrastructure is one of the issues dealt with in the Master Plan (DDDA Master Plan 1997: Part 5 Transportation and Infrastructural Framework; DDDA Master Plan 2003: 61-70).

Traffic has been an important issue in the entire inner city of Dublin for a long time. Traffic jams and congested roads are normal. Cycle paths were almost unheard of. The heavy traffic from the port goes directly along the north side of the river Liffey, right through the city centre.

All these issues have to be tackled by the DDDA. The development of the quays and campshires as public amenities also includes cycle paths and wide walkways. The controversially discussed port tunnel might not be the perfect solution, but will eventually take away a good part of the heavy port traffic from the city centre and the north docklands (DDDA Master Plan 1997: 74; DDDA Master Plan 2003: 61- 
70). ${ }^{15}$ The expansion and construction of new roads and bridges over the Liffey are supposed to remove vehicle traffic from the inner city (McDonald 02/08/2000, 10/05/2001, McNally 24/08/2001).

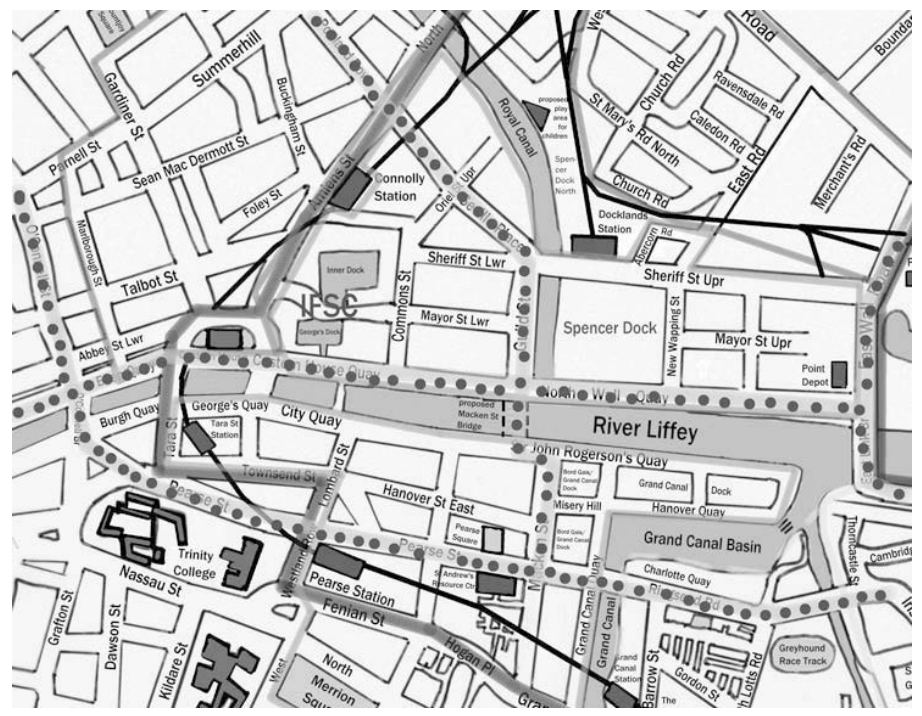

Fig. 3: Spencer Dock, proposed playground and Macken St Bridge and highly congested traffic routes (dotted lines) (Astrid Wonneberger)

One of these plans includes the construction of a new bridge at Macken Street/Guild Street. The idea is to divert traffic from O'Connell Street, Dublin's main street, and the north inner city, down Seville Place, towards the new bridge and the south side of the river. This bridge was heavily opposed by the local communities on both sides of the river. An environmental impact study for the bridge predicts the decline of traffic on O'Connell Street, but at least a $20 \%$ rise of traffic pollution in the communities of Pearse Street and the North Wall. Already suffering from heavy traffic along Pearse Street and Seville Place, accompanied by rising levels of asthma and chest infection of inner city children, the residents opposed the plans (e.g. C3, C35, C30b, C44, C92, C69). ${ }^{16}$

15 Due to misplanning - the tunnel is too low for the new European super trucks (cf. Sheehy 19/08/2004: 9; C35) -, delays and failures, the tunnel project has been highly controversial and a regular topic in Dublin newspapers since 2000. See for instance Fetherston 02/10/2002: 10; Hogan 11/08/2005: 5; O'Rourke 22/02/2006: 16.

16 Some residents published their anger in form of letters to editors of newspapers, for instance Devlin 21/03/2001. 
Eventually, however, the bridge got planning approval in 2001 (McNally 24/08/2001), but its construction only started in 2007 and has not been completed yet.

On the north side, the people feel particularly affected by the bridge. The reason becomes obvious with a look at the map (Fig. 3).

Seville Place is already a strong traffic-dependent boundary within the community. Children who live on the north side of the road have difficulties crossing over to the school and playground on the south side. Several petitions to the City Council and public protest marches were necessary to get a set of traffic lights (C35). With the establishment of the new bridge, residents fear that the community will be completely cut into two halves, as it will be increasingly difficult to cross the street. A new playground, which is badly needed in the area, is planned for the new development in Spencer Dock. However, separated from the community by both canal and Guild Street/Seville Place, it will be very difficult and dangerous for children to cross over to the new amenity (C35, C30b, North Wall News August 2004). ${ }^{17}$

"The traffic will be worse if Macken Street opens. Children won't have any access to the playground at Linear Park, because they won't be able to cross Seville Place. The community is already parted in two by the traffic in Seville Place. [...] If the traffic does not kill us, then the fumes will." (C35)

"They know that [the bridge] is not going to do any good for the people that live here. These are residential areas. [...] It's our children that will have asthma, bronchitis and diseases. [...] All those tourist attractions around O'Connell Street - they are not the heart of what Dublin is. The heart of what Dublin is is the people. Without the Dublin people there is no community. [...] It doesn't seem to matter that they are killing people for it [the new bridge and traffic relief in O'Connell Street].” (C44)

The Macken Street Bridge has not been finished yet. Therefore it remains to be seen how much impact it will really have on the communities and their boundaries. However, this example shows that undivided territories are of utmost importance in maintaining functioning social structures. In this sense, physical transformations can change the community structure significantly.

17 The bridge and its impact on the community was also an important issue at the public monthly meetings between the developers at Spencer Dock North, John Thompson \& Partners, working on behalf of Treasury Holdings and the Spencer Dock Development Company, and the North Wall community (2003). 


\section{Privatised spaces: the "Berlin Wall"}

The creation of new administrative boundaries and physical borders is only one aspect of changing urban space and their impact on everyday life in the docklands. Another fundamental transformation of the dockland communities and culture is marked by the increasing privatisation of places that used to be public or at least publicly accessible. A few examples, such as the dock basins, have already been mentioned. People also complain about the fact that green spaces they used to play in as kids are turned into building sites and therefore lost as amenities (e.g. C81a). The most dramatic changes however, are caused by the new apartment complexes that formed one of the key elements of the early phase of redevelopment. Approximately 1,500 residential dwellings were constructed in Phase 1 of the Master Plan between 1996 and 2002. A further 6,500 to 9,500 residential units have been planned to attract 23,000 new residents to the area by 2012 (DDDA Master Plan 2003: 4045).

These new apartments are not considered a threat to the communities per se. After decades of decline and decreasing numbers of residents, community members are generally delighted to see new life in the streets around the former derelict areas. Contrary to new office space which only enlivens the area during the day, residential areas are always alive. Statements by community members illustrate this attitude:

"At least the area will not be dead at the weekend, because it is all apartments down there [Pearse Street area] now. It is being revitalised with people, whether it is families or not." (C81b, similar statements by C86d, C83b)

The erection of new apartment complexes however, also creates privatised residential spaces which have never existed before to such a large extent. They also mark a new internal boundary between two populations in the docklands - the old communities on the one hand and the new residents on the other. One interviewee explains:

"Today I would think the most dramatic changes would be the new developments, and I think they are good for the people and they are good for the area. I see them as very positive and very good. But the interaction with the people going into the new apartments is not very good. I would have liked to see that these people buying all these new apartments would become more involved with the community. But maybe they will integrate better later." (C87) 
In some cases, this division is even expressed in the architecture, in the form of physical boundaries and walls between the two populations.

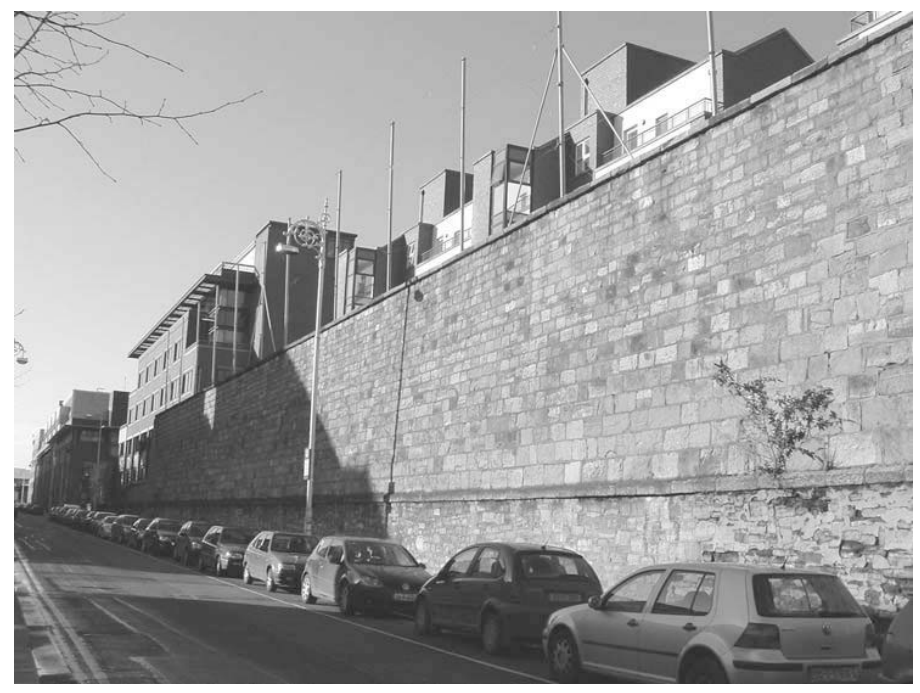

Fig. 4: Berlin Wall (photo: Astrid Wonneberger)

The most vivid example is the so-called "Berlin Wall" which divides the North Wall community from the inhabitants of the IFSC. When the first part of the docklands was redeveloped, the only structure that was left on the Custom House Docks site was - apart from the basins - an approximately five metre high wall surrounding the former coal yard and docks. Separating the old public housing complexes in and around Sheriff Street from the new residential areas in the IFSC, the "Berlin Wall", as it became locally known, was and is perceived as a clear and intended boundary between old and new residents:

"The wall was here originally, but the poles on top and the wire, they weren't. The apartments separate themselves from the community. If the wall was a metre or two metres high, I'd understand it, but a wall that high - they could have taken it down. And then they added this barbed wire. [...] When I saw it first it reminded me of a concentration camp with electric wire on top of it. [...] I mean, they don't make themselves welcome." (C44)

This example of a physical boundary between residential groups became so famous that even newspapers started to report about it. The "Berlin Wall" became a symbol of exclusion and stigmatisation: 
"The wall has been there as long as anyone can remember, but it is now arousing very strong feelings in those who live on the other side of it. 'It is to keep us apart from the yuppies,' one of the women in the North Wall Centre says with disgust. 'They've made their own ghetto in there,' says another. 'But they need it,' someone else argues. 'If the wall wasn't there, those nice flats would be wrecked once the gurriers ${ }^{18}$ got at them.' They all collapse with laughter when someone remarks, 'I know a postman who goes in there. And he says they're all weirdies.' [...] But the wall that's run unnoticed along Sheriff Street for decades now seems to stand for something new: a tangible symbol of a divided community." (What's In A Wall? 30/09/1997)

The "Berlin Wall" is certainly an extreme example for an artificial physical boundary in Dublin. Nevertheless, almost all new apartment complexes that were built prior to 1997 - and a few even after that have one feature in common: they are all gated, i.e. surrounded by gates that allow access only to residents.

Gated residential areas are not an invention of Dublin planners. Residential developments surrounded by walls or other means of barriers go back as far as the 1850s in the USA, when the elite barred themselves and their wealth off from the poorer classes. The first middleclass so-called "gated communities" began to emerge in the 1960s. This development was accelerated in the 1980s, and by the 1990s it was common all over the United States. Transformations in the political economy of late twentieth century urban America with weakening social ties and lack of local control, racism, fear of crime and developers' interests to maximise profit have been analysed as driving factors for this development (Low 2006). The reasons leading to a parallel development in Dublin in the late 1980s and early 1990s show some similarities with the American case, but there are also regional differences. In order to fully understand the complex consequences, a closer look at the dockland communities, the new residents and the housing situation in Dublin in general will be necessary.

With the "Celtic Tiger" boom ${ }^{19}$, property prices have increased enormously, up to $299 \%$ over the last decade (Permanent TSB House Price

18 Dublin slang for "street urchins", kids hanging out on the streets (cf. Share 1997).

19 Derived from the East Asian Tiger economies, the name "Celtic Tiger" refers to a period of rapid economic growth in the Republic of Ireland between the early 1990 s and early 2000 s. Triggered by low corporate taxation, EU funding, low-cost labour market and a policy of restraint in government spending, which are seen as the most commonly named causes for this boom, the Celtic Tiger has on the one hand been responsible for Ireland's modernisation, low unemployment rates and economic growth 
Index, quoted in "Decade of Growth for Dublin Market" 26/07/2006: 21). Apartments in prime areas such as the docklands adjacent to the city centre are extremely valuable, while the reputation of indigenous dockland communities is still not the best. For this reason and general safety issues all over Dublin, gates were introduced in the new residential developments in order to decrease the (assumed) risk of burglaries. This physical gap between the two populations of new and old residents is further enhanced by cultural and social gaps. The indigenous communities and the new residents - often referred to as the "gated communities" $" 20$ - have completely different social and cultural backgrounds. Although the demographics are changing, the indigenous dockland residents are still characterised by relatively large families. Third-level education is an exception, low-skilled jobs and unemployment are frequent (ESRI 1996). ${ }^{21}$ Many families have lived in the area over generations. Grandparents, children and grandchildren often live side by side in the same public housing complexes. Each community is characterised by close networks within the area.

Instead of large families, the vast majority of the new residents live as childless singles or couples in these city apartments. They are mostly young, i.e. between 20 and 35 years of age, and have received some form of third-level education. They often work in the financial or ITsector and they are very mobile. The city apartments are usually left after a few years. ${ }^{22}$ If a family is planned, they look for a house in the sub-

and wealth that led Ireland from a "backward" country right into modern Europe. On the other hand, critical voices see the downside in a widening gap between the rich and the poor, rising house prices which favour developers and investors but make it very hard for people with lower and middle incomes to buy or even rent their own house or apartment. See in detail Coulter/Coleman 2003.

20 The term "gated communities" is often used by the old-established communities to describe the new residents, particularly the ones living in the gated complexes. However, I prefer the term "new residents", as they lack any features of a "community", as will be explained later. Another reason is that not all new residents live in gated apartments.

21 Although the economic and educational profile has already been improved since the beginning of the DDDA scheme, it is still under Dublin average in 2002, as the DDDA Master Plan Monitoring Report 2004 revealed.

22 In order to increase the rates of owner-occupiers in the new apartments, the government increased the threshold for stamp duty relief from $€ 190,500$ to $€ 317,500$ in 2004 . To keep this first-time buyer exemption the buyer must reside or have somebody occupy the dwelling on his/her behalf for the first five years (Revenue Office, private e-mail). As a direct result the latest developments have a much higher owner-occupation (up to $80 \%$ in the Gasworks for instance) than the previous complexes where, in one example, as few as six investors own 170 apartments $(\mathrm{C} 78, \mathrm{C} 88)$. In 
urbs. Their social networks are not connected to the area, but reach out all over Dublin and beyond. For this reason they have a completely different view on the local environment. They barely know about the history and tend to use new bars, cafes and shops rather than the old community venues, if they use them at all and do not prefer to meet friends outside the area. $^{23}$

For all these reasons, the two populations have barely any contact. Facing the growing numbers of new residents who are only perceived as anonymous masses, many community members feel threatened. On the one hand, they are afraid that they will be outnumbered by the new residents soon. Moreover, some people expressed concerns that the new inhabitants with their good education will distort the statistics, so in future financial support for the area will be cut short. On the other hand, they fear they may be expelled indirectly by increasing property prices and decreasing numbers of social and affordable housing, particularly since many former dock workers do not see themselves as part of the new image the DDDA is creating for the area (e.g. C84a, C84b, C44, C3).

The few attempts to get in touch with the new residents have not been very successful so far, but this issue of integration has been acknowledged as one of the most urgent problems to be solved in the future by community leaders. The aim is to create a new and growing, but still functioning community in the area, which means getting in touch with the new residents, informing them about existing community structures and establishing new social networks. Whether these attempts, such as a meeting between community members, new residents and local enterprises in April 2006, will be successful, remains to be seen.

In general, the local communities are not happy with segregated neighbourhoods, and the gated apartments and the "Berlin Wall" are the most visible barriers for this development. These new boundaries manifested in the new architecture of the docklands are perceived as gaps that

June 2007, the government announced another stamp duty reform, which will now include the complete abolition of stamp duty for first-time buyers (Cabinet expected..., 20/06/2007).

23 There are no statistics available on the new residents. My findings are based on interviews, observations and mental maps. According to these data, the new residents are very homogenous in the characteristics mentioned. For example, in the Gasworks, a new development with over 400 units, my interviewees mentioned having seen only three families with a child in the entire complex. Nobody remembered seeing any resident over 40 or 45 years of age living in the complex. All my interviewees had some kind of third-level education and all their social networks reached far beyond the area. Their consensus on the other aspects mentioned is equally high. 
make it even more difficult to overcome the already existing cultural and social differences. The gates, for instance, hinder the delivery of the local magazine to the new residents, which is distributed personally to every household in the community in Pearse Street. An important means of communication thus fails.

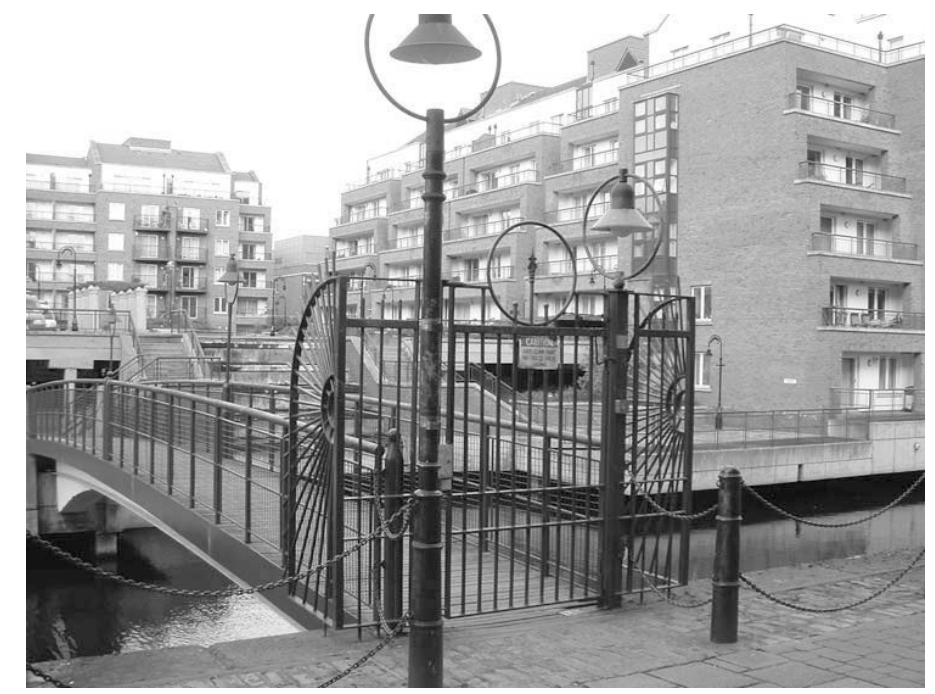

Fig. 5: Gated apartments (IFSC) (photo: Astrid Wonneberger)

Gates and separated spaces are considered "untypical" for the culture of the indigenous residents. In a community where everybody knows everybody, neighbours visit each other regularly and greet each other on the street, many people regret the fact that the doors that used to be open all the time in the past are now locked. The new gates are considered by many residents to be responsible for the decline of the close-knit sense of neighbourhood in the area, preventing the delivery of local publications and creating an atmosphere of anonymity. Gates and walls as part of the redevelopment of the docklands are therefore considered a threat to the functioning communal structure.

"We want to stop all that, the gated apartments, where they are cut off from the community. [...] It looks to us like a fortress. It cuts off this whole development away from us. [...] I mean they can't create these clinical communities where weird people don't exist. Faceless people. It is not in our interest to create separate communities." (C3) 
"Developers coming in destroy the community piece by piece. [...] Just up the road there, there are a couple of houses that have been derelict for years and they are being torn down at the moment and converted into apartments. [...] They are gated. They are not part of the community. And there used to be families that knew each other. So the communities are being torn apart bit by bit." (C44)

These arguments are not just wide-spread among dockland residents. The debate about the pros and cons of gated developments, the necessity for a safer urban living on the one hand, and the negative effects on community formation and integration in urban neighbourhoods on the other, started in Dublin as early as the construction of the first gated residential units in the 1980s. Finally, in the mid-1990s, the latter arguments became more popular and a general shift in the development of urban quarters could be observed. Further pushed by community representatives who were involved in the planning process of the DDDA Master Plan, the DDDA abandoned gates from their plans altogether. While the very first development of Clarion Quay still has gates, the majority of the new residential quarters along Hanover Quay, Gallery Quay or The Gasworks are all open, which means pedestrians can walk through the premises and have access to the front doors. A few exceptions can be explained by the fact that the planning process is not only in the hands of the DDDA, but can be overruled by Dublin City Council.

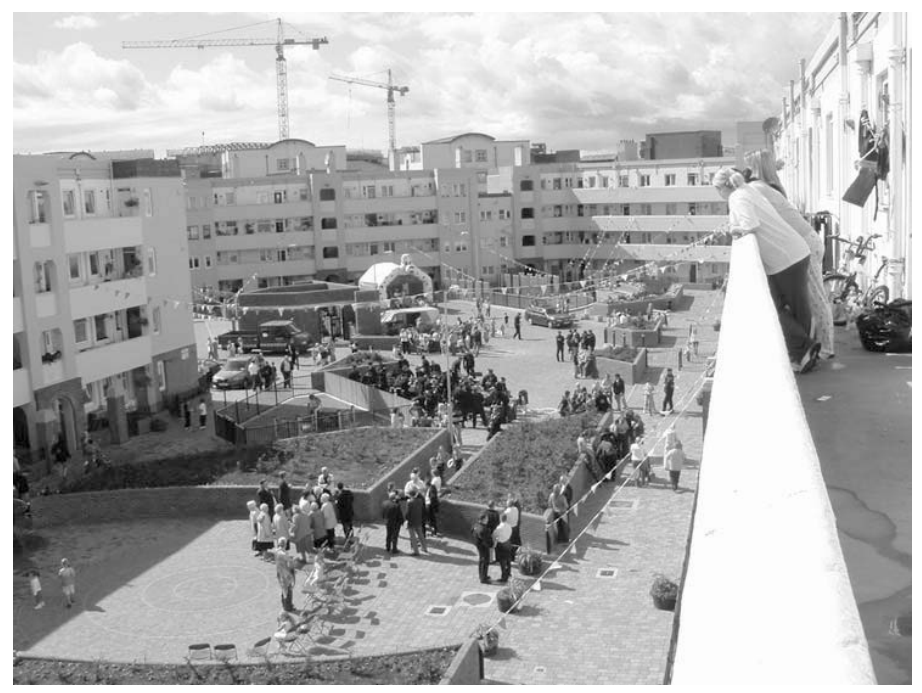

Fig. 6: Balconies (old social housing: Pearse House) (photo: Astrid Wonneberger) 
Nevertheless, the problems and consequences for the area remain the same. The privatisation of public spaces continues. Even if gates are missing, the new apartment complexes are separated, more than any residential area in the past. This becomes particularly obvious for children, who used to be able to visit any of their friends in houses or social housing complexes by just knocking at their doors or looking through the windows. In the new apartments, pass codes and bells make it much more complicated to get into the complex, as a 12 year-old boy explains:

"In the new apartments you need a pass code to get in. And that is not fair because sometimes my friends are not at home and I just want to go in and see if there is anyone there. But I can't. There is glass doors you can see through, but there are always buildings in the way to see who is there. In the flats you just look out over the balcony and see who is down in the flats or just knock at a door. In the new apartments you have to go in to see who is there. In the flats it is no hassle to walk in and out, in the apartments you need the swiper thing." (C88b)

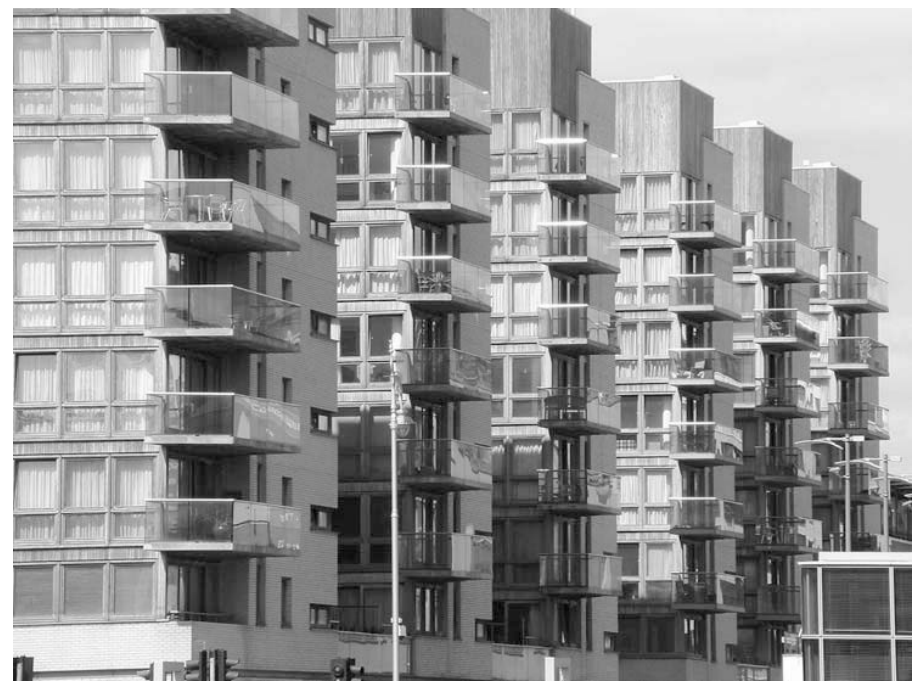

Fig. 7: New apartments (photo: Astrid Wonneberger)

The lack of the old-style balconies, which are mentioned in the quotation above, brings another change to the old ways of living. In the old social housing complexes, the entrance doors to each flat lead out to a balcony which faces out to the main yard. The balconies are part of the daily life: Neighbours meet each other for a chat on the balcony, and they are a perfect viewing point for what is going on in the yard. Private life is 
much more communal than in the new style apartments, where balconies are entirely private, stairwells are not very inviting for a chat, and the general layout makes it impossible to know who is at home. While some people prefer this new more private atmosphere, others miss the closeness and regular chat with the next door neighbour.

Thus, the new residential architecture is again more than a new design for the dockland area. It also has an impact on long-established patterns of behaviour.

\section{Conclusion}

The regeneration of the Dublin docklands is only on the surface an exclusively physical transformation of an urban environment. Naturally, physical changes are the most visible ones - so visible that some longterm dockland residents barely find their way through their new environment.

On the micro-level however, more dramatic changes become obvious. New boundaries - visible and invisible ones - create new forms of exclusion, be it from education or training schemes for individuals, or from financial benefits for a community. New problems arise with the construction of new roads, bridges and consequent traffic, not only causing health problems, but also separating communal entities.

On the symbolic level, old communities seem to be losing their sense of place and their feeling of connectedness to an environment that the residents still perceive as their own territory. Most old port-related buildings have been demolished, and the new glass facades do not substitute the old meanings of heritage and identity. The physical space as a means for the formation of community identity is losing its importance.

Moreover, community members are more and more afraid of losing their community spirit, which used to be one important marker for a dockland culture in the past.

Growing numbers of new residents in the area remain distant from the old-established communities. Different life-styles and different cultures, as well as the new architecture, make it difficult to bring the two groups together: Gates and privatised spaces leave other residents out and inhibit direct and personal communication. Even in the new social blocks, which are predominantly inhabited by members of the oldestablished communities, the old-style personal communication seems to decrease, as the new apartment blocks lack the balconies offering space for a chat with the neighbours or for watching the courtyard below. 
However, despite many fears of disadvantages on both individual and communal level, and a general feeling that the indigenous dockland communities should have a greater share of the new wealth and profits around them, many aspects of the rejuvenation process are considered positive: Community members are represented on the board of the DDDA. The campshires are still publicly accessible. New social housing schemes, education and training programmes were developed and derelict areas are now revived. All this is generally acknowledged and regarded as a new chance for the old communities and their members.

The transformation of the Dublin docklands is an ongoing process, which will not be finished until 2012 at the earliest. Therefore, many changes have still to take place. It remains to be seen which of the anticipated consequences will actually happen, and which will not occur. The long-term effects of dockland regeneration in all its facets and on all levels, have to be the object of further research. Only the future will tell whether the old dockland communities will be able to survive, or whether some new form of communal identity will arise among old and new dwellers in the area. This article has shown how communities and identities, specific local places and spaces are intertwined. It remains to be seen whether this close sense of locality will survive, or if it is substituted by new forms of territorial references.

\section{References}

Appadurai, Arjun (1991): “Global Ethnoscapes. Notes and Queries for a Transnational Anthropology”. In: Richard G. Fox (ed.), Recapturing Anthropology, Working in the Present, Santa Fe/New Mexico: School of American Research Press, pp. 191-210.

Barth, Frederik (ed.) (1969): Ethnic Groups and Boundaries. The Social Organisation of Culture Difference, Bergen/Norway: Universitetsforlaget.

Buchel, Peti/Hogervorst, Bert (1997): The Turning Tide, Amsterdam: The IJ Industrial Buildings Guild in Cooperation with De Appelbloesempers.

Byrne, Katriona (2001): Pearse Street D2. A Study of the Past. A Vision for the Future, Dublin: Dublin Civic Trust.

"Cabinet expected to approve FF's stamp duty reforms" (2007). Irish Examiner, Breaking News, 20/06/2007 (http://www.irishexaminer. com).

Cohen, Anthony P. (1985): The Symbolic Construction of Community, London/New York: Routledge. 
Coulter, Colin/Coleman, Steve (eds.) (2003): The End of Irish History? Critical Reflections on the Celtic Tiger, Manchester/New York: Manchester University Press.

DeCourcy, J.W. (1996): The Liffey in Dublin, Dublin: Gill\&Macmillan. "Decade of Growth for Dublin Market" (2006). LifeTimes 26/07/2006: 21.

Devlin, John (2001): "Macken Street Bridge". Letter to the Editor. The Irish Times 21/03/2001 (http://www.ireland.com).

DDDA (2007): "News: Dublin's Docklands becomes the place to live and work in 2006". 09/01/2007 (http://www.ddda.ie/cold fusion/ news/press_releases/press_releases2.cfm?counter=218).

DDDA (2005): Master Plan Monitoring Report, March 2005.

DDDA (2005): $3^{\text {rd }}$ Dublin Docklands Social Regeneration Conference Report 2005.

DDDA (2003): “Facelift for George's Dock". Dockland News, June 2003: 5.

DDDA (2003): Social Regeneration Conference 2003 Report.

DDDA (2003): Master Plan.

DDDA (1997): Master Plan.

ESRI (1996): Dublin Docklands Area Master Plan. The Socio-Economic and Employment Structure of the Dublin Docklands Area, Dublin.

Fagan, Terry/Savage, Ben (1995): Down by the Dockside. Reminiscences of Sheriff Street, Dublin.

Fetherston, Neil (2002): "Getting to the Bottom of the Tunnel". North Side People (East), 2/10/2002: 10.

Gilligan, H.A. $\left(1989^{2} / 1988\right)$ : A History of the Port of Dublin, Dublin: Gill\&Macmillan.

Gupta, Akhil/Ferguson, James (1997): “After Peoples and Cultures”. In: Akhil Gupta/James Ferguson (eds.), Culture, Power, Place - Explorations in Critical Anthropology, Durham/London: Duke University Press, pp. 1-27.

Haller, Dieter (1994): Feld, Lokalität, Ort, Territorium: Implikationen der kulturanthropologischen Raumterminologie, Berlin.

Hastrup, Kirsten/Fog Olwig, Karen (1997): “Introduction”. In: Kirsten Hastrup/Karen Fog Olwig (eds.), Siting Culture, London/New York: Routledge, pp. 1-15.

Haughey, Nuala (2000): "Planners Reject Major Part of Spencer Dock Proposal". The Irish Times, 14/07/2000 (The Irish Times archive, http://www.ireland.com).

Hauser-Schäublin, Brigitta/Dickhardt, Michael (2003): "Einleitung“. In: Brigitta Hauser-Schäublin/Michael Dickhardt (eds.), Kulturelle Räume - räumliche Kultur. Zur Neubestimmung des Verhältnisses 
zweier fundamentaler Kategorien menschlicher Praxis. Göttinger Studien zur Ethnologie 10, Münster/Hamburg/London: Lit, pp. 1340.

Hannerz, Ulf (1996): Transnational Connections. Culture, People, Places, London/New York: Routledge.

Hogan, Treacy (2005): “ $€ 12$ Port Tunnel Toll to Deter Cars but Lorries Will Go Free". Irish Independent, 11/08/2005: 5.

Low, Setha (2006): "How Private Interests Take Over Public Space: Zoning, Taxes, and Incoporation of Gated Communities". In: Setha Low/Neil Smith (eds.), The Politics of Public Space, New York/London: Routledge, pp. 81-103.

Malone, Patrick (1993): "The Difficulty of Assessment: A Case Study of the Custom House Docks, Dublin”. In: K.N. White et al. (eds.), Urban Waterside Regeneration. Problems and Prospects, New York et al.: Ellis Horwood, pp. 116-126.

Malone, Patrick (1996): "Dublin: Motive, Image and Reality in the Custom House Docks”. In: Patrick Malone (ed.), City, Capital and Water, London/New York: Routledge, pp. 65-89.

McDonald, Frank (2001): “A Maestro's Plan for Links across the Liffey". The Irish Times, 10/05/2001 (http://www.ireland.com).

McDonald, Frank (2000a): The Construction of Dublin, Kinsale/Ireland: Gandon Editions.

McDonald, Frank (2000): "Construction of New Bridge across Liffey at Docklands a Strategic Necessity for City". The Irish Times, 02/08/2000 (http://www.ireland.com).

McNally, Frank (2001): "Liffey Bridge Gets Planning Approval". The Irish Times, 24/08/2001 (http://www.ireland.com).

North Inner City Folklore Project (eds.) (1992): North of the Liffey, Dublin.

North Inner City Folklore Project (eds.) (no year given): Living in the City, Dublin.

North Wall News, published by the North Wall Community Association, August 2004.

O’Rourke, Pat (2006): “Leaking Tunnel Row Drags on”. Northside People (East), 22/02/2006: 16.

Rapport, Nigel (1998³/1996): “Community”. In: Alan Barnard/Jonathan Spencer (eds.), Encyclopaedia of Social and Cultural Anthropology, London/New York: Routledge, pp. 114-117.

Rolshoven, Johanna (2003): "Von der Kulturraum- zur Raumkulturforschung". Zeitschrift für Volkskunde Vol. 99, Münster et al.: Waxmann. 
Seymour-Smith, Charlotte (1986): Macmillan Dictionary of Anthropology, London/Basingstoke: Macmillan Press.

Share, Bernard (1997): Slanguage - A Dictionary of Irish Slang, Dublin: Gill\&Macmillan.

Sheehy, Clodagh (2004): "Boring Details as Light at the End of Tunnel Emerges in Drill of a Lifetime". Irish Independent, 19/08/2004: 9.

Tomforde, Maren (2006): The Hmong Mountains. Cultural Spaciality of the Hmong in Northern Thailand, Southeastern Asian Modernitities Vol. 5, Hamburg: Lit.

"What's In A Wall?" The Irish Times, 30/09/1997 (http://www. ireland.com).

Winthrop, Robert H. (1991): Dictionary of Concepts in Cultural Anthropology, New York et al.: Greenwood Press.

Wonneberger, Astrid (2005): "Vom Schmuddelimage zur Weltstadt: Bilder der Stadt Dublin im Kontext der Hafenranderneuerung". Informationen zur modernen Stadtgeschichte (IMS) 2005 (1), pp. 1825.

Wonneberger, Astrid (2006): “'Hard times they were, but we survived.' Urbane Lebensstrategien in den Dubliner Hafenvierteln in den 1920er bis 1960er Jahren”. Ethnoscripts 8 (1), pp. 7-21. 


\title{
Old Town and Dock Area: Structural Changes in Ciudad Vieja of Montevideo
}

\author{
Mijal GANDELSMAN-TRIER
}

Ciudad Vieja is the oldest part of Montevideo, a small district close to the centre and solitary at the same time. Situated on a peninsula, it is almost surrounded by water. A low ridge stretches across the terrain offering views of the sea and the port. Protected and restored historic buildings stand next to derelict houses. Narrow streets and dense buildings shape the urban landscape. The prevailing colour is grey, but from any street corner the view to the water reveals brightness, vividness and vastness.

The intention of this paper is to give an insight into characteristic features of structural change in Ciudad Vieja of Montevideo, the historical centre and port-related district of the city. An ethnographic view of local transformation aims at focusing on the diversity of urban life and on concurrent processes of change which do not correspond to only one logic of transition. Although structural alterations can be related to global aspects of transformation of port cities, transition in Ciudad Vieja of Montevideo has to be considered as an open process. Current urban developments are not submitted to a general revitalisation plan for the dockland area as in Dublin or Hamburg, but as part of the master plan for Montevideo, they are linked to projects of different social and cultural actors and their urban practices.

This paper presents results from my recent research in Montevideo on consequences of global transformations on the local level of a dockrelated quarter (Trier 2005), emphasising the specific context of this particular city. My approach takes into account the social practice of actors, their strategies of action, ways of perception and appropriation of 
space and place, discourses, identities and representations within the scope of a changing local setting. ${ }^{1}$

Following the model of Hoyle (1988), city ports are submitted to vehement processes of transition. ${ }^{2}$ Technological changes, in particular containerisation and computerisation, are to be seen as starting points for a new era in maritime development. The waterfront, as interface between port and city, is changing, too, leading to a revitalisation of portrelated areas. As a consequence of these processes docklands are losing their "traditional" cultural role. Urban planning projects are usually dedicated to multiple uses such as offices, services, housing, cultural activities, tourism, etc. attracting new middle classes and in many cases initiating displacement or exclusion of old neighbourhoods. In other words, revitalisation processes are often accompanied by the effects of gentrification.

Montevideo seems to be on the edge of these processes. Ciudad Vieja eludes any explicit categorisation. It is both, old town and dockland area. Ciudad Vieja does not represent a "typical" dock area, although it is the major national port location. A large number of banks, trade companies, business and public authorities are situated in Ciudad Vieja, at the same time it is home to predominantly poor inhabitants. Deterioration and decay gave rise to images of danger provoking avoidance of the area. However, inhabitants of Montevideo recently rediscovered Ciudad Vieja as an urban space and as a place for leisure and entertainment. Nevertheless Ciudad Vieja remains a neighbourhood with a close social structure as well. Transition seems to occur as a contradictory process, various trends and developments are happening simultaneously pointing to different directions. But undoubtedly, in Ciudad Vieja things are changing.

In the following article, I shall describe these inconsistencies and interconnections on the local level, and relate them to processes of transformation on the global level. The article explores current processes of change, identifies groups of actors, their practice within the setting, the implication of the port-city interface and the consequences of transformation.

1 The research project is based on ethnographic fieldwork conducted in Montevideo between 2003 and 2005. In order to ensure the anonymity of the local actors and interviewees all names referred to in this paper are changed.

2 See Schubert in this volume. 


\section{Ciudad Vieja: Evolution and features}

As the historical centre of Montevideo, Ciudad Vieja is the point of departure for the history and urban development of Montevideo. Particularly relevant in this context are transformations during the second half of the 20th century, which led to a dramatic decay of the district. Today Ciudad Vieja seems to be at a turning point, again.

Montevideo was founded 1724 as a fortress to defend Spanish colonial interests against those of the Portuguese empire. Located on the estuary of the Río de la Plata and situated on the shore of a protected bay, Montevideo evolved as a port. Nevertheless, the city and port of Montevideo remained small and provincial until the middle of the $19^{\text {th }}$ century. Until then, Ciudad Vieja represented the political, economic and social centre of the town, all relevant and representative institutions, organisations and enterprises being located there including the residence of middle classes and national and local governments. ${ }^{3}$

The country's history, since the 1830 s, has been greatly affected by mass immigration. At the beginning of the $20^{\text {th }}$ century, the Uruguayan government established new political guidelines related to industrialisation, urbanisation and constitutional reforms, a modernisation of the nation-state which aimed at attracting European migrants who became the main protagonists of this evolution. ${ }^{4}$

Montevideo prospered both as a port of exit for raw materials, and as a port of entry for European migrants. The population increased enormously within a few decades. ${ }^{5}$ Montevideo rapidly expanded beyond the boundaries of the old town. In Ciudad Vieja, port and port-related trade and industry became the driving force of economic growth. At the same time the resident population began to decrease, especially middle and upper classes abandoned the district gradually transforming Ciudad Vieja into a poor part of the city. This process led to deteriorated housing conditions as one relevant feature. Many people felt constrained to live in so-called conventillos and casas de inquilinato, both kinds of room by room tenancy in former residential colonial style buildings. ${ }^{6}$ In

3 For further details see for instance Barrios Pinto/Reyes Abadie (1997), Barrios Pintos (1998), Gans (1987), Grupo de Estudios Urbanos (1987).

4 For further details see Caetano/Rilla (1997).

5 Growth in population concerning Montevideo: 1830: 14,000 inhabitants; 1905: 250,$000 ; 1914: 380,000 ; 1935: 655,000$. Today the number of inhabitants of Montevideo amounts to 1,32 millions approximately, considering the metropolitan area to 1,66 millions. In Ciudad Vieja reside about 12,000 to 15,000 inhabitants. Recent statistical data refer to another unit than the regarding district.

6 For further details see for instance Di Paula (1996). 
the 1950s, a severe economic crisis caused, among other things, progressive degradation and decline of Ciudad Vieja. Deprivation and deterioration increased under the rule of the military regime (1973-1984). Due to guiding principles of economic liberalisation, more and more old houses were demolished while new office buildings were built. As a result of the continuing crisis those sites increasingly remained empty. Derelict houses were occupied by families affected by extreme poverty.

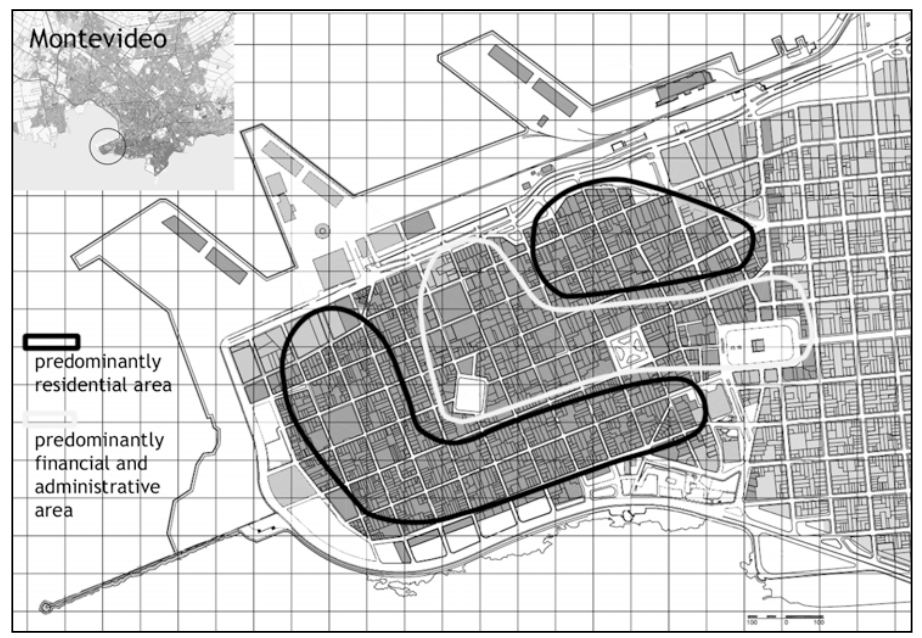

Fig. 1: Ciudad Vieja: Areas with different uses and functions (Reproduced by kind permission of IMM; adapted by Mijal Gandelsman-Trier)

Since the beginning of the 1990s the situation gradually changed. Today, Ciudad Vieja can be described as a heterogeneous district. It is a historic city centre and residential area; it is a representative location for public and private institutions and a place where poor segments of the population live; it is a tourist attraction and a dockland area. Many historic buildings are under preservation orders, while at the same time others are collapsing. As an inhabitant pointed out, "there is not only one Ciudad Vieja, there are many" (field note, 11/10/2005). ${ }^{7}$ Different uses can be assigned to different spaces. Functions can be approximately localised in specific zones. To mention the most relevant distinction, edifices related to administration and finances are predominantly located in the centre of the district, residential buildings are mostly situated close to the waterfront. But perception of different spheres within Ciudad Vieja

7 Translation of quotations from interviews from Spanish (original) into English by myself (M. G.-T.). 
is not organised in a dichotomised manner. There are no definite demarcations separating one area from another, transition prevails against boundaries. Emphasising discrepancies: There is a significant difference in the numbers of people staying in Ciudad Vieja during the day, and during the night or at weekends. ${ }^{8}$ After work hours, most areas of the district seem to be deserted and public life is restricted to few places.

Meanwhile, the docks still occupy the same territory in which they were constructed historically. In Ciudad Vieja the port did not retire from the city. Therefore, relevant revitalisation projects concerning the port-city interface do not exist. ${ }^{9}$ However, the area remains a relevant location for port-related firms, such as import and export companies, insurances, etc. In the 1990s, structural adjustments to global conditions in seaport systems led to an enormous reduction in workplaces within the port of Montevideo. A large number of stevedores and dock workers lost their jobs. Subsequently most cultural sites related to the docklands such as pubs, bars, brothels, etc. disappeared.

Presently, different plans to redevelop the area exist, including private, public, and social projects.

\section{Current processes of change}

In Montevideo processes of change are embedded in a consistent concept of urban planning, the "Plan Montevideo", a master plan for the whole city, and the "Plan Especial Ciudad Vieja", a subsequent executing plan dedicated to the district of the old town. Within this master plan, urban development is conceptualised as a momentum of social and cultural integration. Concepts and measures are considered as instruments to improve urban setting through guiding principles. Relevant objectives stated in the documents include the preservation of the historical architectural fabric, the struggle against the decline of population in the city centre by promoting projects to resettle inhabitants, counteracting urban segregation, opening more urban space to the public, and consolidating the image of the district in order to strengthen the process

8 According to a personal information from "Centro Comunal Zonal No. 1" during office hours about ten times more persons stay in Ciudad Vieja than after business hours. $(14 / 01 / 2004)$

9 One project to revitalise former port areas exists in the adjacent district $\mathrm{La}$ Aguada. The so-called "Plan Fénix", however, had to be stopped due to the economic crisis between 2002-2003. For further details see for instance: Zillmann 2001. 
of cultural, social and economic revaluation (IMM 1998; IMM 2004). ${ }^{10}$ "Plan Montevideo" and "Plan Especial Ciudad Vieja" have been elaborated by the municipal department of urban planning on behalf of the government of Montevideo. ${ }^{11}$

Current changes are related to the physical environment as well as to the social structure of the area. Particularly within the last decade several architecturally relevant buildings have been restored. Due to a project focused on vocational training of disadvantaged persons, a number of house fronts have been painted. ${ }^{12}$ A larger intervention into urban space is connected with the project of a pedestrian precinct on Sarandí Street, the east-west-axis along the peninsula emphasising Ciudad Vieja's characteristic shape. This axis opens the view of the waterfront: the sea respectively Río de la Plata on the one side, the harbour bay on the other. Besides its geographical significance, Sarandí Street represents a relevant reference for all kinds of economic and cultural activities.

In recent years Ciudad Vieja has regained an attractiveness as a significant place of cultural $^{13}$ interest. A number of renovated buildings are now used as museums or cultural centres. Particularly artists, craftsmen and other cultural actors have discovered the area as a place to settle. Studios, small art galleries, arts and crafts stores and jumble shops have been opened, but this new cultural scene is competing with an older one, which is directed towards a more affluent clientele, offering antiques, jewellery and art. In between, there are street vendors selling arts-andcrafts objects, and flea markets around the main square. In addition, mostly young people from all over Montevideo have discovered restaurants in Ciudad Vieja as fashionable places, and new cafés, pubs and bars were set up. The quarter is one of the prominent locations for cultural events. Due to historical places of interest and colonial style build-

10 Relevant guiding principles of planning policies are for instance: To preserve the urban texture, to improve urban space, to recover the communal patrimony, to ensure circulation of public transport, reduction of number of vehicles and improvement of situation of pedestrians, to improve the quality of life of inhabitants and users of Ciudad Vieja, to define and consolidate the image of the district. (IMM 2004: 34f)

11 Mariano Arana, a professor of architecture who, at the time of the military regime, founded the "Grupo de Estudios Urbanos", an oppositional urban planning group, was mayor of Montevideo from 1995 to 2005. His ideas on urbanity influenced the master plan.

12 The project is called "Ciudad Vieja Renueva". During 2004-2005 many activities were developed supported by funds from the EU. For further information see: http://www.montevideo.gub.uy/ciudadvieja/.

13 At this point and particularly in the following section "Emerging cultural scenes" I emphasise a meaning of "culture" as practice related to art institutions and to the art scene. 
ings Ciudad Vieja is among the most relevant tourist attractions of the city and is incorporated into regular sightseeing tours. In order to further enhance the area's attractiveness, the tourist authority, as well as local actors, promote its closeness to the port, hoping to attract more visitors from the cruise ships.

House building cooperatives are an important feature in the transformation processes of the old town. The cooperatives are part of a social political movement, representing an important tradition of protest and civic action groups within the national context. ${ }^{14}$ In the case of Ciudad Vieja the purpose is to combine the objective of obtaining living space at a reasonable price for families with low income, and the idea of renewal of old buildings. The contribution of members mainly consists of volunteering their manpower. Since the 1990s several pilot projects started. Meanwhile a few projects have been completed and members of the cooperative projects have moved in with their families. A lot of further buildings are under construction. The municipal authorities of Montevideo encourage the settlement of cooperatives in Ciudad Vieja. Members of the cooperatives are supposed to be socially committed people, willing to get involved in public issues affecting the neighbourhood.

Present activities and developments within the district of Ciudad Vieja have effects on the residential composition of the area. After the number of middle-class residents had declined for decades, there is now a return movement of the middle-class to the quarter. At the same time features of decay persist: deteriorated buildings, houses in danger of collapsing, historical edifices not being restored. There are streets with dilapidated houses mostly inhabited by squatters, poor families with little or no income, and children living in the streets. These different processes coexist simultaneously. There is an unequal development within the small area of Ciudad Vieja. Changes take place at different sites of the district, they are not restricted to certain locations, but transformations do not occur all over the area. In short, changes are selective but related to the quarter as a whole.

Most of the inhabitants living in Ciudad Vieja settle on the edge of the peninsula. Their daily life in the district is restricted to a small area close to their houses, to neighbours, and to shops. Within the scope of Ciudad Vieja they identify themselves as belonging to the barrio. ${ }^{15}$

14 For further details see Nahoum 1999.

15 District or area of the city (translation from Spanish). The concept of barrio plays an important role for the construction of distinct urban identities within the city of Montevideo and refers to social as well as to spatial references. 
Relevant and emblematic markers to describe the barrio include sports grounds of local clubs, the escollera ${ }^{16}$, a small beach, a square, etc. These places are situated in different areas of Ciudad Vieja, but common to all is that they are located outside of the centre of the district. Actors do usually not consider this part of the peninsula as part of their barrio, in some cases people refer to it as la city. ${ }^{17}$ In this way they create a boundary between themselves and those related to the administrative and financial sector, a boundary that to a small degree can be denominated as physical but to a larger degree as symbolic. Residents distinguish the barrio from la city by identifying streets and other landmarks, this way constructing physical boundaries between both areas. By using terms like la city, they symbolically emphasise a distance towards administrative and financial concerns.

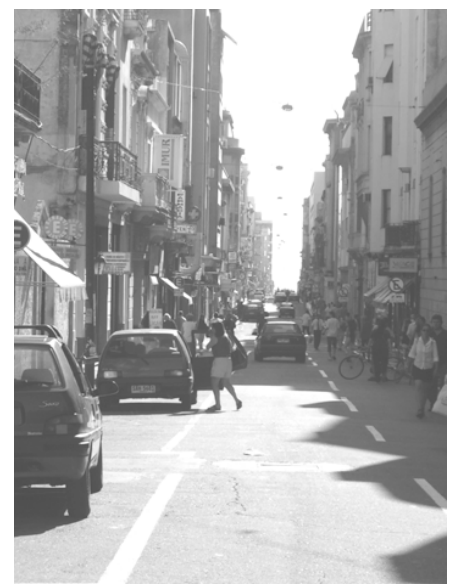

Fig. 2: Pérez Castellano Street (photo: Mijal Gandelsman-Trier)

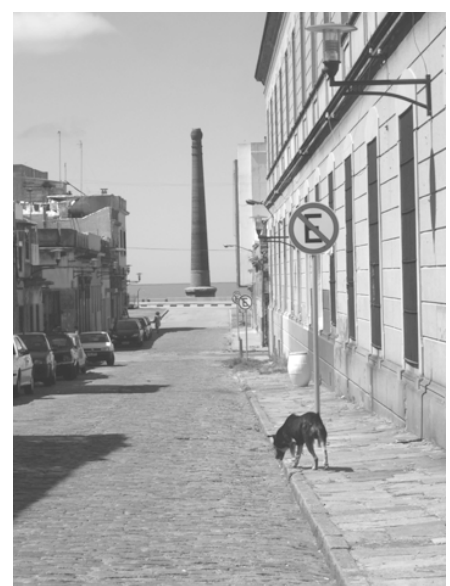

Fig. 3: Setting within the barrio (photo: Mijal Gandelsman-Trier)

Other markers for a local identity refer to memories of the past. Many residents tell stories about a "better past" which is predominantly situated in one's own childhood. ${ }^{18}$

16 Embankment to protect the port. The dam lengthens the line of the Sarandí Street extending the east-west-axis.

17 For instance: Ricardo 12/01/2004; Marcela 28/10/2005; Nuria 11/11/2005; Francisco L. 28/11/2005; Fernando D. 01/12/2005; Hugo T. 01/12/2005.

18 See the following example. Similar statements: José $21 / 10 / 2005$ and 26/10/2005; Carlos F. 04/11/2005; Alfredo 08/11/2005; Silvia 23/11/2005; Hugo T. 01/12/2005. 
"Ciudad Vieja was a good thing for me. We had a good time here. We were poor, of course, almost the whole vicinity was poor, but we had a way of subsistence, there was always work, that is, there was no problem. And among the neighbours there was a lot of help, that is, whenever someone fell ill, they came running to look what happened or they went to the hospital and so on. And, of course, it was a very nice time of my life, of most of the people who lived here $[\ldots]$ and some of us who stayed in Ciudad Vieja remember it when we meet." (Pepe, 10/01/2004)

Life in those times is considered as more familiar, by emphasising the importance of neighbourhood and solidarity. The evocation of a united everyday practice in the neighbourhood is partly owing to former housing in conventillos and casas de inquilinato. Apart from hard living conditions, the conventillos in particular represent an important point of reference in the collective memory of Montevideo. ${ }^{19}$ Neighbourhood and solidarity between the poor seem to be a relevant category for the image of a barrio.

Residents also attach importance to the protection and maintenance of colonial style houses. Looking at the past as a marker for identity seems to be related to an idealised image of patrimonial edifices. ${ }^{20}$ Local actors expect historical buildings to be preserved without any changes. In this case they refer to the district as a whole and not only to the barrio. Changes occurring in Ciudad Vieja are noticed and commented on by the residents, but most of them do not intervene in processes of transformation.

Different types of actors live in the context of Ciudad Vieja. Their diverse local practices do coexist most of the time, but occasionally they clash, showing distinct effects on utilisation, appropriation and representation of public space, and influencing the processes of change. In the following sections, I shall present three examples of contested space, contested images and representations, illustrating the ambiguities of transformation in Ciudad Vieja.

19 Conventillos are associated with the former way of life of afro-Uruguayan in Barrio Sur, a central quarter of Montevideo with one very famous conventillo, the so-called "Medio Mundo".

20 For example: Pepe 06/10/2005; Alfredo 13/10/2005; Norma 02/11/2005 and $02 / 12 / 2005$. 


\section{Emerging cultural scenes}

Going for a walk through Ciudad Vieja on a late Saturday morning in summer: Starting from Plaza Independencia, a large and representative square - the place of transition between the centre of the city and the old town - and crossing Puerta de la Ciudadela. This ancient entry to a former citadel today is the most representative access to Ciudad Vieja. Sarandí Street, the pedestrian precinct of the old town, commences here. Most of the time it is extremely windy at this point. A little further, people sit in cafés in the open. Close by, small but expensive shops offer products like leather goods, jewels, antique books, and art. Small wooden stalls are set up on Saturdays along the wall of a historical building. They all look the same, since they belong to a corporation that gives licences to artist-craftsmen. Craftsmen sell their goods: self-made jewellery, decoration, souvenirs, craft commodities. In the middle of the street, young people put up their products for sale on a piece of cloth on the ground. They are informal street vendors.

Approaching Plaza Matríz, the central square, the scene becomes crowded with people. Acrobats and mimes show their skills. In front of the Cabildo, the seat of government in colonial times and nowadays a museum, is a small stage, where music and dance groups, among them many children, perform regularly. The presentations are organised by the same corporation that manages the street vending of arts and crafts. Plaza Matríz is bathed in light. Old plane trees offer plenty of shade creating a vivid play of light and shadow. On the paths intersecting the square many stands are put up which belong to an autonomous organisation with specific rights linked to the square. They sell small antiques like silverware, porcelain, and jewellery, coins, books, jumble and arts and crafts. The right to hold a market at this privileged place on Saturdays implies the duty to be present on certain other days ${ }^{21}$, a problem for traders and craftsmen who work full-time in one or two other jobs. Many visitors and strollers walk around, look at the presented goods and have a chat with a trader on the history of a product, maybe about a glass milk bottle from the 1960s. But only few people buy something: To go to the market of Plaza Matríz means a nice family trip looking at interesting and curious old objects, explaining to one's own children how things worked in the past. Most of the visitors are Montevidean, some are tourists from Argentina or Brazil and occasionally there are travellers from afar. On the other side of the square, next to the cathedral, a

21 Market regulations based on an agreement between trader organisation and the municipality of Montevideo. 
young man with a megaphone announces a bus tour through Ciudad Vieja and the port. He belongs to a small association ${ }^{22}$ that buys and repairs old busses and presents them to the public on simple sightseeing tours. Leaving Plaza Matríz and following the east-west-axis toward the point of the peninsula the street is growing emptier. On both sides houses are currently being renovated, due to the transformation of this section of Sarandí Street to a pedestrian mall. The end of the street offers a panoramic view towards the dam and the sea.

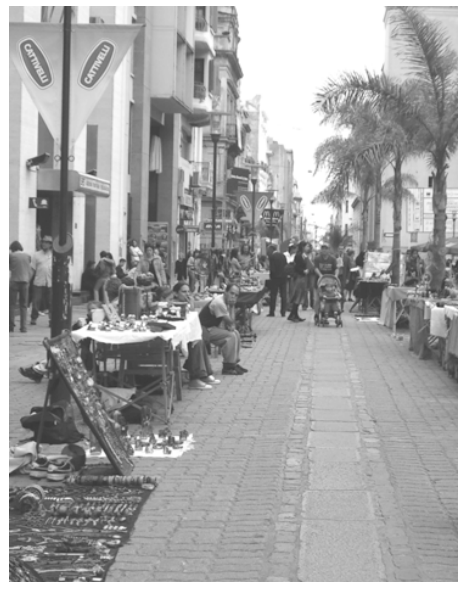

Fig. 4: Craftmen offering their goods (photo: Mijal GandelsmanTrier)

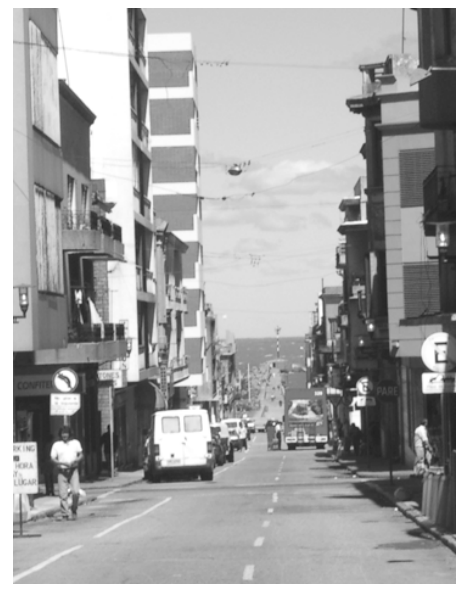

Fig. 5: Sarandi Street (photo: Mijal Gandelsman-Trier)

Turning north, the view alters, overlooking the port with few cargo ships, a modern container terminal, cranes, perhaps a cruise ship, the bay in the background and the Cerro, Montevideo's emblematic hill, on the opposite shore. ${ }^{23}$ Following Pérez Castellano Street small shops and galleries offer paintings and objects of arts and crafts. However, here is only little business on Saturday morning. Sometimes a few passengers from a cruise ship pass but most of them are taken by tour operators to conventional tourist attractions. There is more activity near the supermarkets, the fruit seller and greengrocer, the bakery, the butcher's shop

22 The name of the association is "Equipo Recopilador Histórico de Tránsito - ERHITRAN", in translation: Team Historical Collection of Transport.

23 The hill is a relevant symbol of national identity represented on the coat of arms. According to a legend the Cerro was the reference for the name of the city of Montevideo. 
and the pharmacy. Residents use this part of the street to buy everyday essentials and for informal meetings. At the end of the road there is a little square, an open space in front of the former port market, today a well-known location for restaurants. This square is used by street vendors and craftsmen. In the course of the day, at lunchtime, the area will be crowded with people, Montevideo residents and visitors who eat out on Saturday. The place is situated near the waterfront but cut off from the bay by a busy road and by the port, nowadays closed to the public. At this point, the walk comes to its end.

Most of the craftsmen and artists as well as other shop owners are organised in "Portal Pérez Castellano", an association founded in 2004 consisting of residents, actors of the cultural scene and businesspeople in the immediate vicinity of Pérez Castellano Street. The objectives of "Portal Pérez Castellano" are to improve the local standard of living, and to embellish the environment. They aim at a more attractive milieu for commerce, tourism as well as for the residents. The idea is to create a "cultural district" and to decrease petty crime, counteracting the persisting image of a "danger zone". In order to reach these goals, the managing committee of the association is involved in local politics and urban planning, e.g. in transforming part of Pérez Castellano Street into a semi-pedestrian street in order to invite more visitors arriving at the port to walk through. Nevertheless, there have been disputes between members of the association, since several shop owners fear disadvantages in business, whereas the cultural scene as well as resident members expect improvement. Other types of activity are cultural events which take place particularly in the summer, such as mural painting, performances or exhibitions. Many academics, artists and other residents involved in the cultural sector join the ideas and objectives of "Portal Pérez Castellano", while most other residents more or less ignore this association. Not all members of the association are residents of the district, since many artists do not live there, however they spend most of their time in their studios or galleries in Ciudad Vieja. Thus, "Portal Pérez Castellano" represents special interests within a limited area of Ciudad Vieja and not the (imagined) entirety of the local residents.

On the opposite side of the district, another organisation deals with cultural activities as well. Founded in 1999 by businesspeople and companies, the corporation "Paseo Cultural de Ciudad Vieja" aims at revitalising the old town by promoting culture, tourism and commerce. "Paseo Cultural de Ciudad Vieja" organises the above-mentioned craftsmen on Sarandí Street and the performances in front of Plaza Matríz. While the "Paseo Cultural de Ciudad Vieja" publicly presents itself as a corporate actor, the firms and companies it represents do not appear 
in public. In contrast to "Portal Pérez Castellano" it does not develop its pursuits collectively, but by means of a small office that manages and realises all projects. This practice of "Paseo Cultural de Ciudad Vieja" does not include residents and individual actors. Both organisations have similar purposes and deal with cultural events in order to change the image of Ciudad Vieja and to increase its attraction, but they work on different levels. While "Paseo Cultural de Ciudad Vieja" is better known, more influential and deals with more financial funds, "Portal Pérez Castellano" acts on a grassroots level. The association is related to an emerging cultural scene in the area.

Not all actors mentioned before agree with these two organisations or feel represented by them. Instead, there are a number of particular interests: The traders on the antiques market on Plaza Matríz do not want to be bothered by "Paseo Cultural de Ciudad Vieja", they prefer to remain independent. The street vendors in front of the port market do not feel accepted by "Portal Pérez Castellano", they suspect that they will be no longer wanted in case of a transformation of the zone into a semi-pedestrian street. The interests of the informal craftsmen on Sarandí Street run contrary to those of the businesspeople selling jewellery, arts, etc. Some shop owners have met to organise their protest against the street vendors and several additional issues by which they felt obstructed, whereas the craftsmen try to conquer an area of public space by establishing a common-law right to stay. In some ways Sarandí Street can be considered as a contested space. ${ }^{24}$

Cultural activities play an increasing role in the practice of actors within Ciudad Vieja as well as for the image of the quarter. Apart from local associations and the influx of artists, a lot of museums are located in the district and have recently been renovated, opened or re-opened. The prestigious theatre "Teatro Solís", for example, is situated near Puerta de la Ciudadela, a place of transition to the adjacent centre of the city. Several cultural centres work within the area. One prominent example is the "Centro Cultural de España", set up in a famous former ironware store with funds from the Spanish government. Besides, particularly young people from the middle classes go out in Ciudad Vieja, frequenting pubs and bars and transforming a few streets nearby the Puerta de la Ciudadela into an entertainment area over the weekend nights. Some of these institutions and activities have existed for decades, but the cultural potential of Ciudad Vieja has only been rediscovered in

24 The current municipality of Montevideo aims at solving such kind of problems on a political level open for talks, avoiding expulsion, looking for a compromise or offering alternatives. 
the last decade. Nowadays, there is an incipient dynamic, a process which attracts actors involved in arts and culture from all over Montevideo to the old town.

\section{Politics on a local level}

Since the beginning of the 1990s the government of Montevideo has introduced policies to encourage decentralisation and participation. ${ }^{25}$ In order to achieve these goals, Montevideo has been divided into 18 zones, each of these endowed with a communal structure to enable the residents of each district to influence political decisions on a local level. Since then, civil involvement has been a strongly discussed issue. There is a continuous public discourse on what is going well and what does not work with participation, and on how it could be made more effective and how more people could be motivated to join in. ${ }^{26}$ The district of Ciudad Vieja and adjacent quarters belong to "Centro Comunal Zonal No. 1". On an organisational level, these communal centres combine employment on a full-time basis and volunteer work of local representatives. The office is represented by a teacher, a social worker, a technical engineer, administrative assistants, and the political chair person. They are well grounded in the matters and problems of the area. Representatives of the residents are organised in a local council, they are considered to be the advocates of local interests. In the course of time most of them have become experts for their district, too. Both levels are expected to offer contacts and agency for the residents. The communal centres are supposed to take up the causes of the citizens, suggestions as well as complaints and recommendations, to work on the issues, to pass them on or to put them into action.

Most relevant topics during the period of my fieldwork dealt with questions related to housing, employment and public safety. Regarding these points transformation of the area seems to be a merely implicit

25 Decentralisation and participation are key concepts within policies of local development, urban social policies and local government. For further details see for instance Gallicchio (2004) referring to different concepts within the scope of Latin America, IMM (2001a) referring to a network of involved cities as well as IMM (2001b) and Reballato/Ubilla (1999) concerning the particular case of Montevideo.

26 During my fieldwork in Montevideo I had the opportunity to participate in a forum on the municipal level ("Foro Ciudadano Departamental") and similar events on the local level where among others those kinds of questions were discussed. See as well: IMM (2001b). The volume comprises a mid-term review on the debate. 
concern. But as a closer look at the questions shows, they are nevertheless linked to changes occurring in Ciudad Vieja. For several decades, housing shortage, respectively lack of affordable flats, has been an essential problem of people living in the area. ${ }^{27}$ The issue can be traced back to the 1970s when the military regime took a new line in policy and pushed economic liberalisation. However, the deterioration of buildings had already started before due to lack of owners' investments as a consequence of an economic downswing and frozen rents. Living conditions of large parts of the urban poor in conventillos and casas de inquilinato were bad even then. Resulting from a cycle of increasing rents, empty structures, demolition of and construction of new buildings, mainly for the purpose of offices, housing conditions got even worse. At the same time, low income groups began to move from the outskirts to the city centre looking for jobs and trying to minimise transportation costs. Strategies to diminish rental fees consisted in sharing a flat, moving in casas de inquilinato or into so-called pensiones ${ }^{28}$. People without any income began to occupy abandoned houses. In the case of Ciudad Vieja they occupied former famous high-grade hotels. ${ }^{29}$ When the period of the military regime came to an end, housing policy gradually altered but a lot of problems continued. Today, in Ciudad Vieja some families still live under miserable conditions in abandoned and dilapidated houses. Boarding houses are the only option for many poor families, although they are not at all cheap. However, for renting a flat, a deposit would be required in advance on top of the monthly rent, which those families could not afford because they have no permanent jobs. In the pensiones, they have to pay weekly or daily, which adds up to more than a regular monthly rent, and beyond that they have no rights or securities. But most of them either do not have or do not know any other options.

Within the "Centro Comunal No. 1" there is a housing commission which cooperates with local residents. The group consists of employees and volunteers of the centre, actors belonging to the housing cooperative movement as well as few inhabitants who live in pensiones themselves. The objective of the commission is to improve housing conditions within the zone. Parts of their activities include advocating the interests of residents and reporting about housing problems in the area. Most efforts however are directed towards the actual support of affected fami-

27 The problem exists although there is a persistent decline of population in the centre. For further details see Di Paula (1996).

28 Pensiones are boarding houses that rent low-grade single rooms per family with common bathroom and kitchen.

29 In the beginning of the 1990s most of these people were moved to quarters in the outskirts of Montevideo by the municipal authorities. 
lies. During my fieldwork, the commission assisted the organisation of an emerging cooperative of people living in pensiones in order to initiate the necessary steps to apply for a building to be restored. At this point there is a close cooperation between local politics in the form of the housing commission, and members of the socio-political cooperative movement. Representatives of already renovated cooperative buildings help incipient cooperatives by instructing them in legal issues and selforganisation. ${ }^{30}$ It is part of their social and political commitment to contribute to the improvement of their neighbourhood. Thus, cooperatives can be identified as another actor within the transformation process. On the political level, the housing commission is in contact with the municipal administration and negotiates issues related to urban development on a local level. Another aspect of the commission's practice is a close cooperation with a network of institutions and non-governmental groups of social work and welfare. ${ }^{31}$ These groups also focus part of their activities on housing issues, particularly because many of them deal with children from disadvantaged families. In recent years the number of children living in the streets has been increasing. Most of these children are not street kids in the sense that they literally live in the street, but spend most of their time, day and night, in the streets although they have contact with their parents and a place to sleep. ${ }^{32}$ Families residing in pensiones run a high risk, since it is forbidden for children to stay inside the building and play during the day. Therefore it is not surprising that they spend most of their time on the street. The network of social work aims at strengthening the needs and interests of poor residents in the area, thus emphasising the appropriation of local urban space by actors who are usually not visible in public. A counter-discourse is headed by a group of businesspeople who feel their interests threatened. They argue issues of general safety, begging, petty crime, dereliction and the control of informal street vending. Although they demand eviction of people living illegally in dilapidated houses, they do

30 There is a national umbrella organisation that represents most of the housing cooperatives called FUCVAM ("Federación Uruguaya de Cooperativas de Vivienda por Ayuda Mutua", in translation: Uruguayan Federation of Housing Cooperatives for Mutual Help). FUCVAM gives as advisor administrative and legal support to all member cooperatives. The complicated procedures and manifold experiences in the process of setting up a building as cooperative cannot be treated within the scope of this article. See for instance Nahoum 1999.

31 The network is called "Red 'Acercándonos' de Ciudad Vieja".

32 They are called "niños en situación de calle", in translation "children in circumstances of street". 
combine their claims with social demands invoking the danger of exploding social problems. ${ }^{33}$

Within the local setting of Ciudad Vieja, various groups and institutions are socially and politically involved with issues concerning social development. Currently they are opposed by businesspeople who advocate particular interests. But, despite contrary positions, both sides share some common values as well. This seems to correspond to the high value traditionally ascribed to the former "hyper integrated society"34 in Uruguay. Nowadays, the attribution is usually applied to the past, thus contrasting social disintegration of the society today. ${ }^{35}$ With regard to Ciudad Vieja, divergence and fragmentation characterise the current situation as well. The interests of businesspeople, entrepreneurs and other representatives from the middle classes differ to a high degree from the hopes of low-income groups. Whereas the former strive for a district rid of petty crime, drugs, dereliction, etc., the latter want to conserve their barrio as it is and to improve living conditions. The expectations of the business people correspond to features of gentrification, while particularly poor residents oppose big changes. Images and ideas of the future of Ciudad Vieja seem to be contested. Nevertheless, these differences and contradictions have not led to open conflicts at this moment.

To sum up, transformation processes in Ciudad Vieja refer to developments not directly related to the port. Nevertheless, the harbour plays a relevant role in the image of the area. Structural changes in the port are reflected by the residents, alter their relation to the port and have an effect on their perception of the quarter. In this regard it is of particular importance that the imaginary of Montevideo is closely intertwined with pictures related to the waterfront. ${ }^{36}$

33 Data from participant observation at a meeting of the neighbourhood council, 17/10/2005, and subsequent interviews.

34 According to a concept of the Uruguayan Rama (1995: 40-43) the term "hyper integrated society" characterises the highly socially integrated structure of the Uruguayan society up to the 1960s. It is particularly evoked as reference to the period of the batllismo during the first decades of the $20^{\text {th }}$ century, relevant for the nation building process.

35 See for instance De Armas (2005) with the significant title "De la sociedad hiperintegrada al país fragmentado. Crónica del último tramo de un largo recorrido".

36 Moreover, see the cases of Istanbul and Varna in this volume as other examples for the significance of the waterfront for the imaginary of a city. 


\section{The port and the waterfront}

In Ciudad Vieja, unlike many other port cities, there are no relevant planning projects concerning the waterfront with effects on the physical urban space. ${ }^{37}$ Due to geographic conditions and economic circumstances, Ciudad Vieja has not been affected particularly by dereliction of waterfront areas during recent decades. ${ }^{38}$ The physical narrowness of the peninsula and the specific historical quality being both dock area and residential district have impeded the extension of the port. Unfavourable economic conditions affect the current enlargement of the port, and the implementation of goals defined within the port authority's master plan by means of gaining new space from the bay (ANP 1999).

The port of Montevideo is losing its significance for Ciudad Vieja from the point of view of planning as well as with regard to the economy. Looking at the waterfront there is a sharp division between port and quarter marked by the access road to the port, which is busy and mostly used by heavy lorries and container trucks. Economically, the port has lost its position as predominant employer and as a driving force for the development of the area. In the beginning of the 1990s the port authorities started the privatisation of services and equipment. Due to this development, and to continuous automation of work processes, thousands of dock workers lost their employment. This in turn provoked the decline of other jobs within Ciudad Vieja linked to the port as well. As local actors describe the dynamic port quarter of the past in contrast to the present situation, "the port is turning its back to the barrio". ${ }^{39}$

Today the port area is not open to the public, and only a visual connection to the bay is still left. In the past, the residents of Ciudad Vieja had access to the shores. There was a small beach strip where people used to go for a swim and a sports club located close to the water. A barge anchored in the bay which encouraged people to swim out there and to do sports. Today, this place is occupied by a modern container terminal. Residents of the barrio feel strongly affected by the increasing distance between their quarter and the bay. Having lost direct access to the shore a few years ago, today they are concerned about losing the view of the bay. Containers piled up in lines have the effect of a wall that is getting higher and closer. The view of port and bay nevertheless

37 See for instance the case of Dublin within this volume.

38 However, in adjacent districts like La Aguada exist large areas with abandoned warehouses and depots, also shut down industrial plants around the bay.

39 For example: Pepe 10/01/2004; Raúl 17/01/2004; Teresa 19/01/2004; José 26/10/2005; Carlos F. 04/11/2005. 
remains from elevated points in Ciudad Vieja. Roof terraces are very common in local colonial style buildings and frequently offer a free view of port, bay, and Cerro. The master plan for Ciudad Vieja considers the particular topographic conditions of the peninsula and lays down protected visual axes not to be obstructed (IMM 2003 and IMM 2004). A continuing latent conflict exists between urban planning and economic interests represented by the port authorities. Even if the port lost its prominent role for the residents' every day activities, it remains a strong point of reference for constructing images of the quarter and of the past. Numerous stories do subsist, relating to former jobs as dock workers, to smuggling, to earning money by selling snacks at the change of shifts, to bars and brothels existing in abundance near the harbour entrance. Besides, the port has always been a very popular place for a Sunday trip that many interviewees remember from their childhood. The attachment to the harbour is particularly visible at open days, when the docks are crowded with people from all over Montevideo.

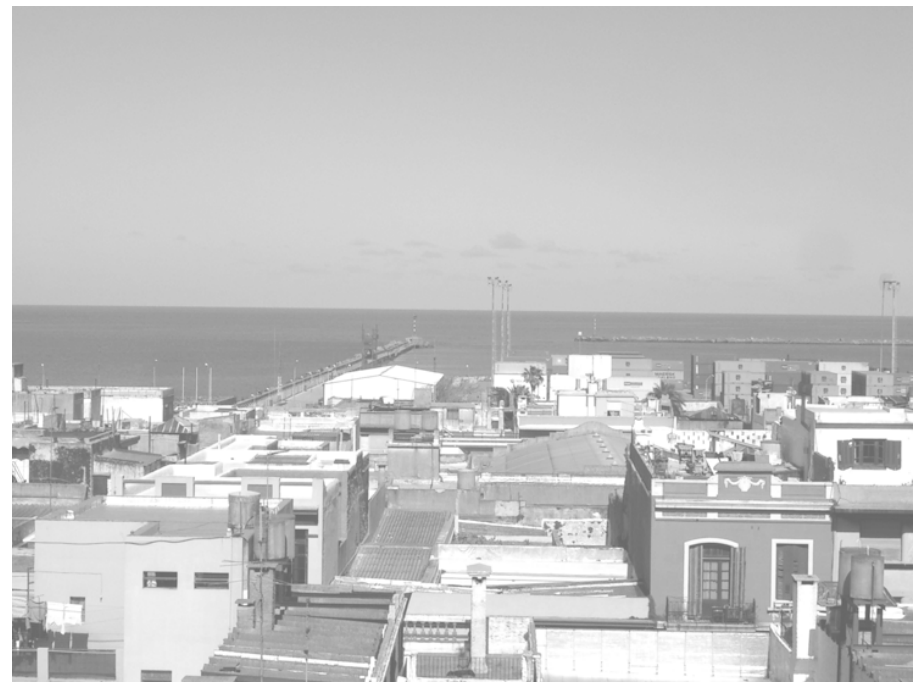

Fig. 6: View from a roof terrace (photo: Mijal Gandelsman-Trier)

Beyond the port and bay there are other relevant points of reference related to the waterfront in Ciudad Vieja. On the one hand there is the escollera, a pier at the point of the peninsula, a breakwater to protect the port marking the boundary between bay and sea. The escollera is an emblematic place, as significant for the past as for the present. Residents remember going fishing with their fathers as little boys at the weekend. 
Today, the escollera still remains a popular fishing ground, and a place to go for a walk and to look at the sea and the sunset. In contrast to other districts of Montevideo, Ciudad Vieja nowadays has no beach apart from a small and dirty strip not even authorised, but nevertheless used by residents.

The rambla, the coastal road of Montevideo, stretches more than 20 kilometres along the shore, at the same time transit road and site for leisure time activities. The rambla is a popular meeting place, a place to fish, to sit down and drink a mate ${ }^{40}$, to do sports, etc. The rambla has no specific significance for Ciudad Vieja but for the whole city. The rambla can be considered as one of the most emblematic places of Montevideo. Many people refer to it describing relevant and popular places in Montevideo and constructing this way the imaginary of the city (Silva 2003). ${ }^{41}$

The waterfront plays an important role in the imaginary of Ciudad Vieja. Various references and connections are related to memories, as well as to activities and practices of today. Only few of these references are concerned with the port. Nevertheless, the port remains present in the mind of the residents although there is an increasing distance between port activities, and the daily life of the inhabitants.

\section{Conclusion}

Ciudad Vieja experiences a process of change that does not take one singular course. Transformation is characterised by disparities and contradictory movements. Differing practices make use of the setting, for instance street vending of crafts, right next to the sale of expensive jewellery, or big business transactions and financial institutions next to robbery, begging, drug-taking, etc. Living within the barrio, incorporated into the networks of the neighbourhood, differs very much from the lifestyle of people working within the administrative and business zone dealing on national and international levels. Newly renovated buildings stand next to derelict or demolished houses, splendid sections turn into decayed areas. However, there is no fixed boundary between all these different spheres and spaces.

Montevideo's port and the district of Ciudad Vieja are undergoing a process of separation according to the global development of city ports

40 Herbal infusion, very popular in the south of Latin America.

41 For further details see: Aguerre (2003); Álvarez/Huber (2004); Silva (2003). 
(Hoyle 1988; Schubert 2001). The docks decreasingly need the vicinity of the city, and as a result the port has lost its importance for the everyday practice of local residents. Although many port-related institutions remain in the area, this spatial proximity no longer has much effect on the economic and cultural life of the district. This trend is illustrated by a great physical and architectural division between the harbour and the city. In contrast to other cities, port authorities in Montevideo do not influence urban development by proposals on waterfront revitalisation. Transformation processes in Ciudad Vieja largely happen beyond port development.

As demonstrated in various examples, transformation in Ciudad Vieja cannot solely be described in terms of waterfront renewal. Instead, it seems to be an inconsistent movement with an open outcome. Some features look like an incipient process of gentrification, such as the emerging cultural scene that has recently begun to settle down in the quarter or those pubs and bars that came into fashion among middle class youth. Current studies of gentrification have emphasised segregation as a relevant feature of such structural urban change. ${ }^{42}$ But in the case of Montevideo, segregation is not characteristic of the ongoing development. Almost all groups acting in the local political milieu stress the aspect of integration, concerning measures against social exclusion. Even the group of businesspeople link their demands against marginalised people with suggestions for social assistance. Segregation is not a dominant discourse within the current socio-political context of Montevideo. ${ }^{43}$ For instance, the master plan for Ciudad Vieja explicitly refers to the problem of gentrification (IMM 2003: 33) and recommends several measures to prevent such developments. Support of housing cooperatives is stated as one relevant measure to combat exclusion and to promote integration within Ciudad Vieja (IMM 2003: 39).

Differing social practices of local actors, as well as inconsistent developments within the architectural environment, point to ambiguous qualities of transition in Ciudad Vieja with an uncertain outcome. Ethnographic research focuses on transformation of this particular quarter and emphasises the diversity of urbanity and local practices.

42 See for instance Lees (2000); Slater (2004); Smith (1979).

43 Since 1990 the city of Montevideo is governed by the leftist "Frente Amplio" coalition. 


\section{References}

Aguerre, Carolina (2003): "The Rambla of Montevideo: Between Land and Water". In: Armando Silva (ed.), Urban Imaginaries from Latin America. Documenta 11, Ostfildern-Ruit: Hatje Cantz Publishers, pp. 193-197.

Álvarez, Luciano/Huber, Christa (2004): Montevideo imaginado, Bogotá: Aguilar, Altea, Taurus, et al.

ANP - Administración Nacional de Puertos et al. (ed.) (1999): Revisión del Plan Maestro del Puerto de Montevideo. Informe final - Resúmen ejecutivo, Montevideo.

Barrios Pintos, Anibal (1998): X. La Ciudad Vieja (2). Los barrios de Montevideo, Montevideo: IMM.

Barrios Pintos, Anibal/Reyes Abadie, Washington (1997): IX. La Ciudad Vieja (1). Los barrios de Montevideo, Montevideo: IMM.

Caetano, Gerardo/Rilla, José (1997): Historia contemporánea del Uruguay. De la Colonia al Mercosur, Montevideo: Colección CLAEH.

Ciudad Vieja Renueva (2004): (http://www.montevideo.gub.uy/ ciudadvieja/) [05/09/2007].

De Armas, Gustavo (2005): "De la sociedad hiperintegrada al país fragmentado. Crónica del último tramo de un largo recorrido". In: Gerardo Caetano (ed.), 20 años de democracia. Uruguay 1985-2005: Miradas multiples, Montevideo: Ediciones Santillana, Taurus, pp. 269-303.

Di Paula, Jorge (1996): "Montevideo. Barrios céntricos y viviendas de inquilinato". In: Hans Harms/Wiley Ludeña/Peter Pfeiffer (eds.), Vivir en el "centro". Vivienda e inquilinato en los barrios céntricos de las metrópolis de América Latina, Hamburg: Technische Universität Hamburg-Harburg, pp. 217-230.

Gallicchio, Enrique (2004): "El desarollo local: ¿cómo combinar gobernabilidad, desarollo económico y capital social en el territorio?". Cuadernos del CLAEH ( $2^{\text {nd }}$ series) 27 (89), pp. 55-68.

Gans, Paul (1987): "Die Altstadt Montevideos. Bauliche und soziale Veränderungen im kolonialen Kern der uruguayischen Metropole". In: Günter Mertins (ed.), Beiträge zur Stadtgeographie von Montevideo, Marburg/Lahn: Marburger Geographische Schriften, pp. 107200 .

Grupo de Estudios Urbanos (1987): Ciudad Vieja de Montevideo. Aspectos socioeconómicos y ambientales, Montevideo: Ediciones de la Banda Oriental.

Hoyle, Brian (1988): "Development dynamics at the port-city interface". In: Brian S. Hoyle/David A. Pinder/M. Sohail Husain (eds.), Revi- 
talising the Waterfront. International Dimensions of Dockland Redevelopment, London: Belhaven Press, pp. 3-19.

Intendencia Municipal de Montevideo (IMM), Unidad Central de Planificación (1998): (ed.) Plan Montevideo. Plan de Ordenamiento Territorial 1998 - 2005, Montevideo.

Intendencia Municipal de Montevideo (IMM) (2001a): (ed.) La Red $\mathrm{N}^{\circ}$ 5 en movimiento. Programa URB-AL. Red N' 5 'Políticas sociales urbanas', Montevideo.

Intendencia Municipal de Montevideo (IMM), Departamento de Descentralización (2001b): (ed.) 10 años de descentralización. Un debate necessario, Montevideo.

Intendencia Municipal de Montevideo (IMM), Unidad Central de Planificación, División Planificación Territorial (2003): (ed.) Plan Especial de Ordenación, Protección y Mejora. Ciudad Vieja - 18 de Julio. Documentos definitivos, Montevideo.

Intendencia Municipal de Montevideo (IMM) (ed.) (2004): Plan Especial Ciudad Vieja, Montevideo.

Lees, Loretta (2000): “A reappraisal of gentrification: Towards a 'Geography of Gentrification'”. Progress in Human Geography 24 (3), pp. 389-408.

Nahoum, Benjamín (ed.) (1999): Las cooperativas de vivienda por ayuda mutua uruguayas. Una historia con quince mil protagonistas, Sevilla/Montevideo: Junta de Andalucía et al.

Rama, Germán W. (1995): La democracia en Uruguay. Una perspectiva de interpretación, Montevideo: Arca.

Reballato, José Luis/Ubilla, Pilar (eds.) (1999): Democracia - Ciudadanía - Poder. Desde el proceso de descentralización y participación popular, Montevideo: Nordan-Comunidad.

Schubert, Dirk (2001): "Revitalisierung von (brachgefallenen) Hafenund Uferzonen in Seehafenstädten - Anlässe, Ziele, Ergebnisse sowie Forschungsansätze und -defizite". In: Dirk Schubert (ed.), Hafen- und Uferzonen im Wandel. Analysen und Planungen zur Revitalisierung der Waterfront in Hafenstädten, Berlin: Leue, pp. 15-36.

Silva, Armando (2003): (ed.): Urban Imaginaries from Latin America. Documenta 11, Ostfildern-Ruit: Hatje Cantz Publishers.

Slater, Tom (2004) "North American gentrification? Revanchist and emancipatory perspectives explored". Environment and Planning A 36 (7), pp. 1191-1213.

Smith, Neil (1979): "Toward a theory of gentrification: A back to the city movement by capital not people". Journal of the American Planning Association 45 (4), pp. 538-548. 
Trier, Mijal (2005): "Ciudad Vieja de Montevideo. Procesos de transformación en un barrio portuario”. In: Sonnia Romero Gorski (ed.), Anuario de Antropología Social y Cultural en Uruguay 2004-2005, Montevideo: Nordan-Comunidad, pp. 181-189.

Zillmann, Kerstin (2001): "Montevideo. Stadt an den Hafen? Die Revitalisierung der Bucht und der Plan Fénix”. In: Dirk Schubert (ed.), Hafen- und Uferzonen im Wandel. Analysen und Planungen zur Revitalisierung der Waterfront in Hafenstädten, Berlin: Leue, pp. 401-217. 


\section{A View from Port to City: Inland Waterway Sailors and City-Port Transformation in}

\section{Hamburg}

\section{REIMER DOHRN}

Every morning, the names of about twelve cargo ships arriving in the port are announced by Hamburg's two daily newspapers. ${ }^{1}$ The vessels listed in the papers include container ships, bulk carriers and cruise ships. Not listed are about 40 inland water way vessels, connecting the port of Hamburg to the Hinterland. These cargo units are around 80 meters long, carrying up to 1,000 tons of goods. Most of them are managed by only two persons, normally a captain and a boatman. Sometimes this function is held by the wife of the captain, who is also the owner. Some ship owners and drivers have a multi-generation family tradition as inland waterway sailors; others are former employees that were forced by their ship companies to become owners. Nearly half of the sailors are employees of shipping companies with 2 to 50 units. As in the port of Hamburg and upstream inland waterway vessels normally ship only during the day, they have to berth for the night in the harbour or on the riversides.

Hamburg's port is by far the largest sea port in Germany, of great economic importance for the country which is dependent on external trade. Since 1999, turnover has been increasing at percentage rates in double figures. The port is part of a North-European hub-and-spokessystem. For many destinations like Asia, South- and North-America and West-Africa, Hamburg is the hub and serves a lot of spoke-ports in

1 Hamburger Abendblatt and BILD. Hamburg, published by Axel-SpringerVerlag, Hamburg. 
North- and Northeast Europe. For other destinations, e.g. East-Africa, Hamburg is a spoke and large ports like Antwerp are the hub.

The port of Hamburg is situated on the river Elbe, 100 river kilometres south-east of the river mouth on the North Sea. In the port area, two tunnels run under the river, one for cars and one for pedestrians. The first bridges upriver of the estuary are at the southern edge of Hamburg's port area. Three ferries cross the port area of the Elbe and two car-ferries far below Hamburg provide further connections across the waterway.

For most residents of Hamburg, the Elbe and the harbour constitute not only a major attraction which they can look out on from the town centre, but also a barrier to their mobility, although new town planning projects, aiming to reduce this inconvenience, invoke a "leap over the Elbe" (FHH 2005: 4). On the other hand, the residents of Hamburg make use of the Elbe to take their guests on harbour tours, hundreds of thousands take part in the port's annual birthday party and politicians regularly stress the importance of the port for Hamburg.

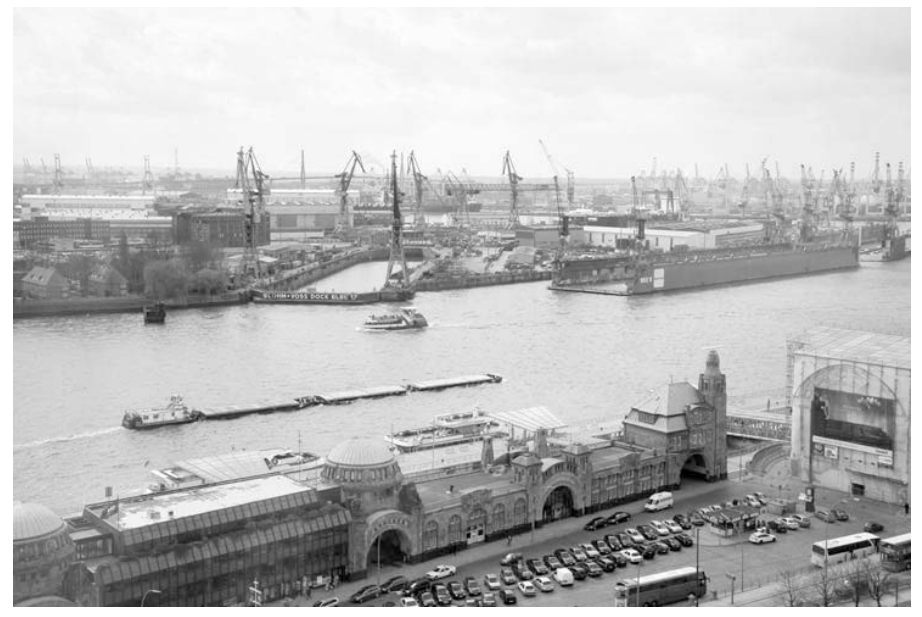

Fig. 1: Convoy of freighters passing Hamburg's inner city piers (Landungsbrücken) (photo: Hinrich Schultze)

The inland waterway sailors' view of the city, meanwhile, is more ambivalent. They look at the city from the water. Being part of the port system, in their view the Elbe and the port are primarily waterways connecting one place to the next. Their daily lives are affected by the mobile nature of their trade, but there is also a desire to live as others do: "The 
others live there, we only drive past ${ }^{\star 2}$ (Wolfgang, 11/10/2004). Although this situation is common for other travelling professions, too, it has become particularly bad for Hamburg's inland sailors due to the decreasing accessibility of the city.

The following article describes the view of inland sailors in the port of Hamburg, thus complementing current research on port cities which has, overwhelmingly, analysed either the consequences of port development for adjacent neighbourhoods and their inhabitants, or processes of urbanisation. The article presumes that the model of city-port development presented by Hoyle (Hoyle 1992: 1-19), with a few adjustments, applies to the port city of Hamburg. The changes in inland sailors' living and working conditions are a case in point. My argument is based on the assumption that existing clashes of interests between economy, politics and actors connected with the port, will become increasingly visible around the port area because of the processes of change and planning, and will also become apparent in dealing with the inland sailors' interests.

The empirical basis for this article are qualitative data from 14 detailed interviews with inland sailors from an ethnographic study in the port of Hamburg in 2004 and 2005, as well as survey data on the inland sailors' economic backgrounds.

\section{Inland navigation and the port of Hamburg}

The fourth phase of Hoyle's model of port-city development (Hoyle 1992: 10; see also Schubert 2001 and in this volume) is on the one hand characterised by the transfer of industrial production overseas and as a consequence, a reduction of jobs and decreasing importance of port cities. On the other hand, the introduction of container ships has caused big changes in this phase. The space required for the handling of this technology is so enormous, that terminals are forced to move further and further away from the city.

As far as the port of Hamburg is concerned, these phenomena can be found to a certain extent. As elsewhere, there was a relocation of secondary industry between the 1960s and the 1980s and shipyards were particularly affected. However, a time lag materialised in the relocation of jobs because of governmental armament orders and guarantees of warship exports, especially at the big shipyards Blohm and Voss (Walden

2 All interview quotations are named by the date of the interview and the name of the interview partner. 
1997: 115ff). Furthermore, regarding the space required by "containerisation" of all maritime transport, in Hamburg the relocation of the port to areas south-west of the city did in fact start in the $1960 \mathrm{~s}$, but continued beyond the end of the millennium. In this process, the dominant dynamic was the container ship sector, making the port city of Hamburg, according to turnover figures, Germany's number one port in terms of technical development of the ship industry (Berenberg Bank - HWWI 2006). ${ }^{3}$

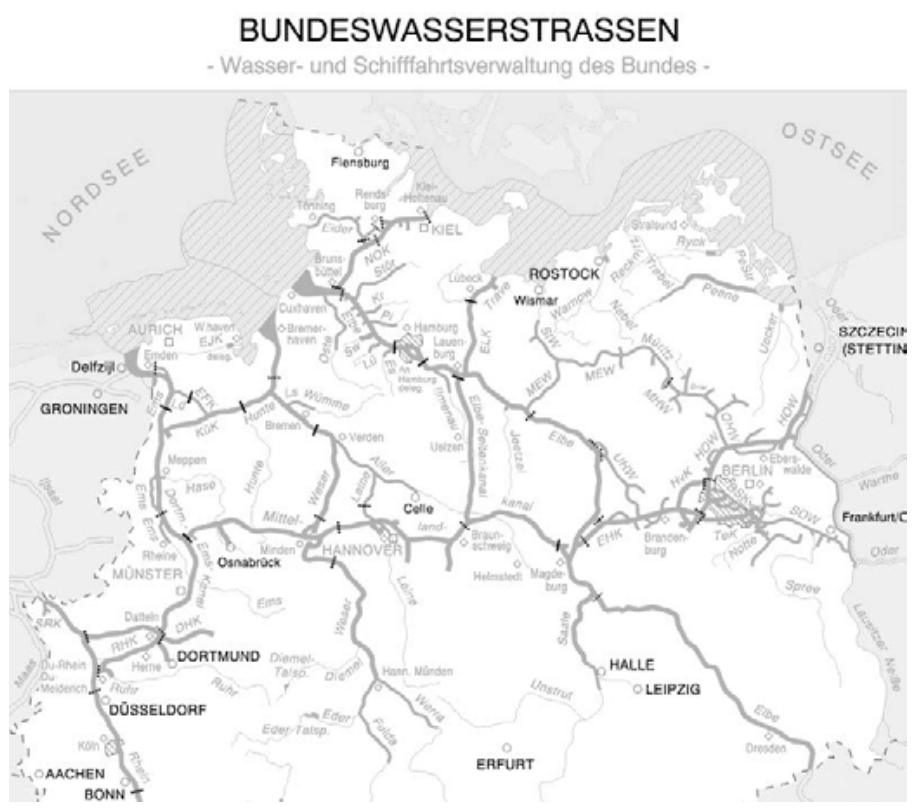

Fig. 2: Map of inland water ways served from the Hamburg port (reproduced by kind permission of Drucksachenstelle der WSV bei der WSD Mitte, Hanover)

A timeframe diverging from the standard can also be found in the area of inland navigation. During the division of Germany, the structure of handling in Hamburg port was strongly influenced by its responsibility for the supply of West Berlin. In the 1980s, more or less one third of the

3 Only in Hamburg did the volume of goods handled between 1997 and 2004 increase by more $(43 \%)$ than in the ports of Rotterdam $(9 \%)$ and Antwerp (29.5\%). For the year 2030, the HWWI predicts joint second place for Hamburg and Antwerp, just behind Rotterdam in the European ranking of port cities. 
inland tonnage load was destined for the exclave of the FRG inside the territory of the GDR. ${ }^{4}$ Of particular importance was the supply of the thermal power stations in West Berlin with fuel, by the inland sailors of West Germany, although they also report about restrictions: "Today there is no more Steglitz or Lichterfelde. And back then it wasn't possible to pass by the channel since the East didn't allow access to KleinMachnow. It was only opened a short time before the Wall came down, five years earlier" (Olaf, Jürgen and his wife, 11/10/2004).

Since the size of the inland vessels depends on the dimensions of the navigable waterways and since only few structural alterations of the waterways have been carried out, technical developments in inland navigation largely passed by West-German vessels. There was also little change in business as the cargo rates were fixed and transport was regulated to guarantee continuity. In the course of German reunification, this was fast and radically changed. The transit regulations were abolished and the state-negotiated distribution of the market shares between the FRG and the GDR was no longer valid.

The disbanding of the economic structures of the GDR on the one hand caused ships and employees of the formerly state-owned East German shipping companies to flood the unified German market. On the other hand, the old workload was partly replaced by selling off much of the former GDR industry. For many sailors, the scrap metal brought by inland vessels to the port of Hamburg from all over the former GDR to be exported by seagoing vessels, became an important transport commodity. "What took place was the scrapping of the GDR. Here in Hamburg almost every day we received and supplied scrap metal. That was crazy. That was the common practice" (Shipping company manager Meincke, 29/10/2004).

In addition to the disappearance of regular orders relating to the supply of West Berlin, the strict cargo rates, which up to then inland sailors had received for trips within Germany, were lifted in 1994. For many decades, this regulation had ensured that all suppliers received fixed prices for different kinds of transport.

On the basis of an investigation by the research group GüterTransportSystem/Logistik (goods transport system/logistics) at the University of Duisburg-Essen, the specialised shipping committee at the trade union "ver.di" determined that the abolition led to a huge increase of workload (Danckwarts/Schürmann 2004: 12). In my investigation in the port of Hamburg, this was confirmed by various statements from my interviewees, e.g.:

4 Estimate according to Gewiese 1996. 
"The pressure on the people has risen many times over. During my time, for instance, there were three or four people on board the inland waterway vessels. Usually there were two qualified skippers on board. Today even larger ships are operated with only two people. That fact alone produces tremendous social pressure." (Wolfgang, 11/10/2004)

These statements correspond to predictions by Hoyle's model (Hoyle 1992: 10) about mechanisation of port work. However, apprenticeship for career inland sailors was only created on $01 / 08 / 2005$, in order to combat recruitment problems. Clearly, changes in transport methods have drastically reduced the time the inland waterway vessels need to stay in the harbour, with the result that fewer and fewer sailors actually enter the city.

\section{Sea port development and the situation of inland sailors}

As described for the fourth phase of the model, the port of Hamburg has increasingly withdrawn from the city. This has had a much larger influence on the situation of the inland sailors than mechanisation itself. Since many peripheral areas of the port are abandoned and not well used, transport connections to the city from areas where the inland waterway vessels can dock have been getting worse. Most of my interviewees confirm this emphatically:

"When doing shift or crew changes, we look out for bus or ferry boat connections. So that we can say: There we can rest, and there we can have our shift changes, where it is convenient, where there is at least a ferry boat going to Baumwall or Landungsbrücken, from where you can go on by public transport. We don't have that at all. In the summer it's okay. But stand somewhere with two bags in the winter in the freezing cold: Where will the ship dock? We'd have to say: here and there." (Dietmar, 01/04/2005)

The following map shows the port of Hamburg with important places for the inland waterway sailors and their basic needs, like shifting crews, buying food, bunkering drinking water and visiting places for social contacts. 


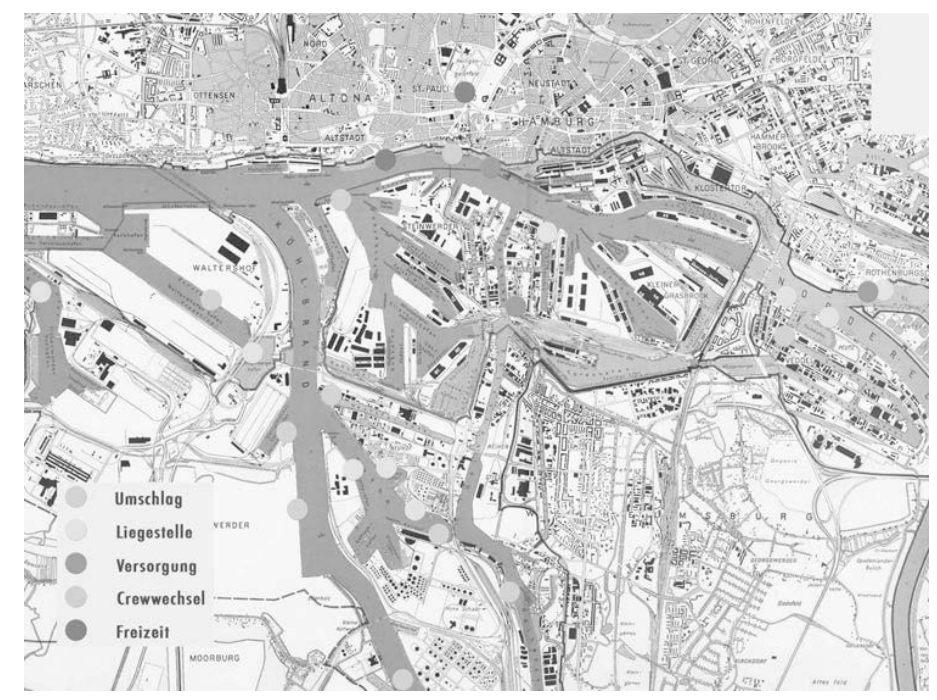

Fig. 3: Map of Hamburg Port (Initiative "Rettet die Elbe", Hamburg, graphic additions by Hinrich Schulze)

However, inland sailors do not only report difficulties at the change of shift. They also report that the increasing distance between the docks and the city makes accessing basic supplies and attending cultural events or social meetings more and more difficult. More than once it was explained to me that the costs of transport from the ship to the city would be many times the entrance fee for the cinema or a soccer game. All in all, the inland sailors complain about a decrease in quality of life caused by the lack of city-centre docks.

The changes to the port of Hamburg have also had indirect effects on the inland sailors. In the development of the port, a particular focus was set on increasing the container traffic on sea-going vessels. As a consequence, the water depth of the Elbe has been continuously adjusted to suit the ever larger container ships. The deepening of the Elbe-waterway was followed by an increased tidal range, meaning that the high tide became higher and the low tide lower. This way, access to the docks near the city was drastically reduced. When the tide is high, the bridges are no longer passable. When the tide is low, the port basins cannot be used by the inland vessels since they are not dredged on a regular basis, and as a result, the water level is too low.

In inland navigation, there is a difference between unloading and loading places on the one hand, and overnight berths on the other. As far as the berths are concerned, until the 1970s many Hamburg boat opera- 
tors benefited from a situation similar to that of navigation in the $19^{\text {th }}$ century: Overnight and in winter, in Hamburg vessels docked in neighbourhoods near the port (e.g. Veddel). Apartments of the inland sailors and their families were often located directly on the bank. This has changed and is described by the sailors as a major problem:

"I would finally bring this misery to an end - that a fully-packed inland vessel can't dock anywhere close to here but only at the end of the world. Look at it like this: after a few days with an easterly wind it is not possible to enter the Billwerder Bucht to get to the docks, even with a draught of just 2.5 meters, since you have to be careful not to get stuck on the flood barrier. To me the situation is unbelievable." (Wolfgang, 11/10/2004)

All in all, my findings show that possibilities for inland sailors to spend their ever-dwindling free time in Hamburg and to find and maintain contacts on land have decreased significantly.

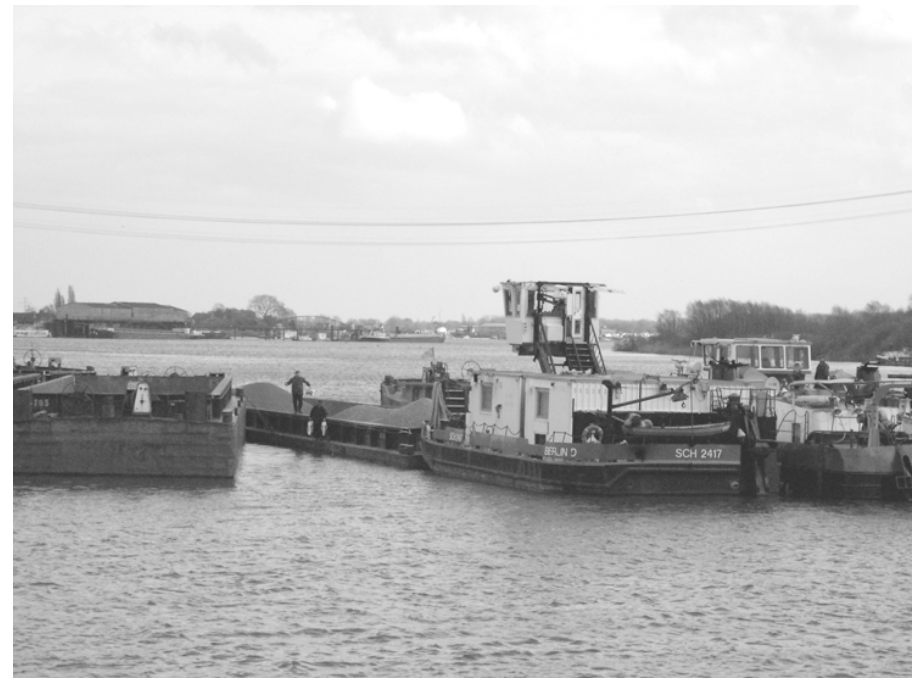

Fig. 4: Inland ships docked in the bay of Billwerder (photo: Marily Stroux)

\section{Consequences of urban development}

Although in Hamburg, relocation of the port away from the city of Hamburg will continue for years or decades (thus confirming phase four 
of Hoyle's model), the next development phase can also serve to describe current changes in the Hanseatic city. Abandoned areas between the city and the port have attracted the interests of city planners and investors, with the goal of revitalising the port and the waterfront. According to Schubert, this group constitutes a "conglomerate of very different and partially contradictory goals" (Schubert 2001: 23). In Hamburg, the most famous and largest example is the so-called "HafenCity" which is currently under construction on the north bank of the river at the eastern end of the harbour. On the outskirts of the port area, which had been for the most part inactive since the construction of the new harbour (and in some cases for a lot longer), a new district of residential, commercial and leisure buildings has been taking shape since the turn of the millennium. Following the prestigious new development of an innercity district, with international connections via the cruise ship terminal in the so-called "overseas quarter", the city seeks to gain the highest possible revenues from selling the surrounding areas, in order to finance the infrastructure of a new container terminal in Altenwerder. ${ }^{5}$

In January 2003, the customs border of the free port was moved to allow access to the HafenCity. Now the duty-free area is on the north bank of the Elbe, and all docks or berths have been removed from there. This means that inland vessels with taxable cargos have to declare them to customs before leaving the free port, in order to continue onto the inland waterways in the interior of the country. This can be difficult, however:

"We can not leave using the North Elbe bridge, because the customs office is only open until $5 \mathrm{pm}$. We can no longer sail out to Peute [berthing place outside the free port in the eastern port area, R.D.] and come back again the next day. It is now an offence to travel out of the duty free area and then back in again. No one gave any thought to the inland vessels which don't reach the border on time, receive their load of containers after $5 \mathrm{pm}$ and as a result have to dock and wait somewhere." (Dietmar, 01/04/2005)

5 In an official statement to the citizens of Hamburg on the 21/05/1997, Mayor Voscherau linked the financing of the Altenwerder container terminal to the income from selling off the city's land, on which the HafenCity was to be built. 


\section{The inland sailors' view: suggestions for improvement}

My fieldwork in the Hamburg port was part of a comparative research project on urban transformation in different European port cities (Kokot 2006). Research was conducted in cooperation with local NGOs addressing local effects of urban change in port-related areas. In my case, this was the Hamburg Riverboat Church, which traditionally had offered its services to inland waterway sailors. One result of this co-operation was a series of events, in which the inland sailors' concerns and their suggestion for improvement were presented to the public.

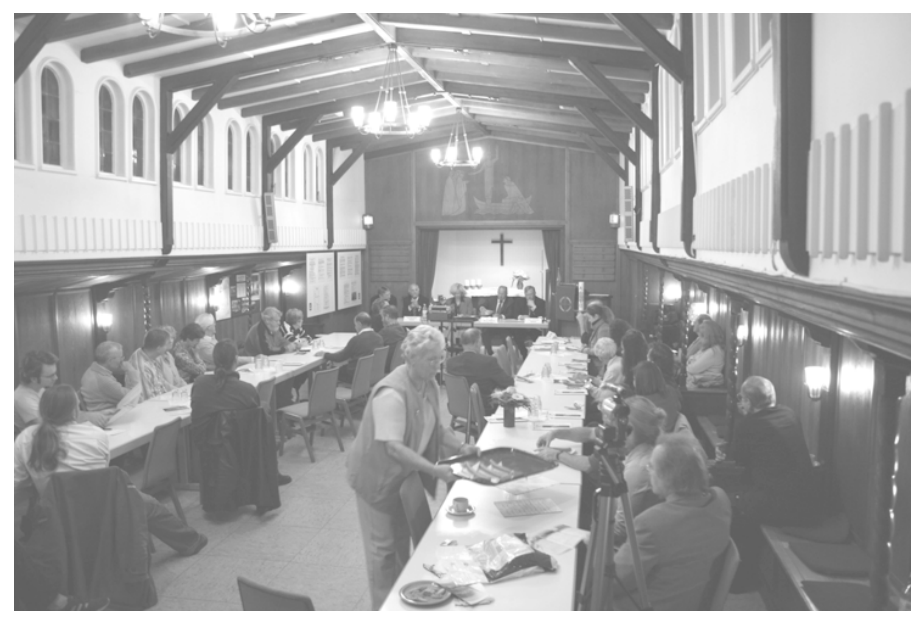

Fig. 5: Public event on the Riverboat Church (photo: Marily Stroux)

As Schubert points out, urban renewal is a "complex network of actors, owners and interests" (Schubert 2001: 27). In the past, suitable docks had been available for the inland vessels in the duty free zone on the north bank of the North Elbe, whose port usage had to give way to the HafenCity. Considering this background, it is not surprising that many inland sailors argued for a central docking bay in the eastern part of the HafenCity, when they were asked for suggestions to improve their everyday work in the Hamburg port, while a representative of the planning company (HafenCity $\mathrm{GmbH}$ ) was not even willing to comment on the suggestion, because its implementation could lead to problems with the contracts. So far, in addition to the degradation already described, only minimal efforts can be discerned on the part of the 
Hamburg Port Authority to address the berthing and supply problems of inland sailors within the current context.

However, future developments may point to a different direction. A doubling of all container transport has been predicted within the coming twelve years (Berenberg Bank - HWWI 2006), which will place a considerable strain on the inland transport networks. Road capacities and rail networks are overloaded already. The forecasted increase in cargo volume can only be reconciled to the political goal of reducing $\mathrm{CO}_{2}$ emissions, by using means of transportation with a low consumption of energy per ton/kilometre. In this context, boats (partly in conjunction with other means of cargo transportation) will have to be reconsidered as a rational option.

\section{Conclusion}

Hamburg harbour has been developing largely in accordance with the Hoyle model - with some adjustments to account for contemporary circumstances. This also applies to the situation of the inland sailors, whose quality of life has been affected significantly by the increased distance between the docks and the town centre. The conflicts of interest which have become evident during the development of the harbour and the planning for surrounding areas are also apparent in relation to the interests of the inland sailors. As a group of harbour users, they feel underrepresented, and largely unheard by politicians.

\section{References}

Berenberg Bank - HWWI (2006): Strategie 2030 - Maritime Wirtschaft und Transportlogistik, Hamburg: Berenberg Bank.

Danckwerts, Dankwart/Schürmann, Udo (2004): Stand und Perspektiven der deutschen Binnenschifffahrt, Berlin: ver.di, Fachgruppe Schifffahrt.

FHH, Behörde für Stadtentwicklung und Umwelt (2005): Sprung über die Elbe.

Gewiese, Armin (1996): Binnenschiffahrt zwischen Elbe und Oder, Hamburg: DSV.

Hoyle, Brian/Pinder, David (1992): European Port Cities in Transition, London: Belhaven Press.

Kokot, Waltraud (2006): European Port Cities: Disadvantaged Urban Areas in Transition: A Collaborative Project of the Community Ac- 
tion Programme to Combat Social Exclusion 2002-2006, Final Report - Phase II Year 2, Institut für Ethnologie Hamburg, Hamburg (http://www.europeanportcities.de).

Schubert, Dirk (2001): "Revitalisierung von (brachgefallenen) Hafen und Uferzonen in Seehafenstädten - Anlässe, Ziele, Ergebnisse sowie Forschungsansätze und -defizite". In: Dirk Schubert (ed.), Hafen- und Uferzonen im Wandel, Berlin: Leue, pp.15-36.

Walden, Hans (1997): Wie geschmiert: Rüstungsproduktion und Waffenhandel im Raum Hamburg, Idstein: Komzi. 


\section{"Gateway" City and Nexus Between Two Continents: The Port City of Algeciras}

\section{CAROLin ALFOnso}

In recent years, "Algeciras" has become a metaphor for the so-called "Fortress Europe". Strategically located to the West of the Strait of Gibraltar, connecting the Mediterranean and the Atlantic worlds as well as dividing Europe and Africa, in times of rapidly developing global migration and communication it has found its firm place in the media as a site of Europe's attempts to secure its borders from the clandestine influx of African migrants. On the other hand, Algeciras has always been a point of departure of European travellers to imagined "exotic" destinations of the African world. But during the summer, European travellers are outnumbered by Moroccan migrants from Spain, France, Belgium and the Netherlands, taking the passage to Tangiers or Ceuta for home leave. ${ }^{1}$

Since the 1970s the port of Algeciras has also become an internationally important node for goods and cargo, developing into one of the leading Spanish ports (APBA 2006). This gave way to massive transformations of the port itself, such as relocating major port functions to deep water areas, and the improvement and enlargement of port facilities. In this respect, Algeciras has been experiencing processes of transition which have affected port cities throughout the world (Hoyle 1988). As a consequence, the waterfront areas have become objects of revitali-

1 It is estimated that in summertime over three million people travel the most important passageway between Spain and Morocco. According to the Port Authority of the Bay of Algeciras (APBA) in 2005 the regular passenger traffic came close to 5 million people and over 1 million vehicles were recorded (APBA 2006). 
sation programmes, which are partly welcomed and partly contested by the inhabitants of the adjacent zones. These processes represent a major challenge to both urban planners and the communities involved.

This paper aims at linking these two topics, by asking how migratory flows and the air of transience affect cultural practices and the reproduction of differences in the port areas of Algeciras. My paper is based on field data gathered in the old port quarter around the public market place, in spring 2003 and summer $2004 .^{2}$

Following a brief summary of the historical development of Algeciras and the port, I shall give a short description of actual characteristics, and problems in the old port quarter. I will then describe new revitalisation processes taking place in the waterfront area, linking them to recent developments in port-city relations.

\section{Algeciras as a port city: Historical outline}

Due to its strategic position bridging two continents and two seas, Algeciras has a long history of settlement. The city itself was founded in 711 under the Islamic dominion as Al Yazirat Al Hadra (la isla verde, the green island). It soon became one of the most important ports of the Córdoba Caliphate and, with the Caliphate's decline, it became an independent kingdom. King Alfonso XI conquered the city in the $14^{\text {th }}$ century, but soon afterwards it was reconquered by the Granadian ruler Mohammad V. Some years later, the city was abandoned and razed to the ground in a desperate defence. It was only at the end of the $18^{\text {th }}$ century that Algeciras resumed mentionable activities as a port city. The International Conference of Algeciras ${ }^{3}$ in 1906 marks the foundation of Algeciras as a port city and the beginning of an intense development, which still continues today. The initial construction of what later would become the quayside, and increased port activities including important subsistence contraband trade with Gibraltar, helped to mitigate the impacts of recession which had hit the whole country due to the political and economic isolation during the Franco Regime (Nohlen/Hildenbrand 2005: 21). All the same, the second and most important impulse took off in the late $1960 \mathrm{~s}$ with the implementation of the plan de industrialización, which included the settlement of heavy industries (petrol refineries, chemical plants as well as steel works) in the bay of Algeciras,

2 I wish to thank Henk Driessen and Waltraud Kokot for initially encouraging me to find my way to Algeciras.

3 In short, the aim of the conference was to convene the then world powers in Algeciras to discuss the future of Morocco. 
as an alternative to the closing of the gate to Gibraltar because of heavy conflicts between the Franco regime and the British government. Furthermore, the plan set precise goals for the development of the port and its facilities. The enlargement of the port coincided with the modernisation of port technologies on a global scale, when technological changes, in particular containerisation and computerisation, were to be seen as starting points for a new epoch in maritime development (Hoyle 1988).

In the following years, the industrial boom along with the extension of the port attracted both Spanish workers and labour migrants, leading to a somewhat chaotic and bumbling development of the city itself. Today, Algeciras is the most important Spanish port in terms of container handling, ranging among the top ten most important ports of the European Union (APBA 2006).

At present, Algeciras counts an estimated 110,000 inhabitants (2003) and is considered as the logistic and administrative centre of the administrative district of the Campo de Gibraltar. ${ }^{4}$

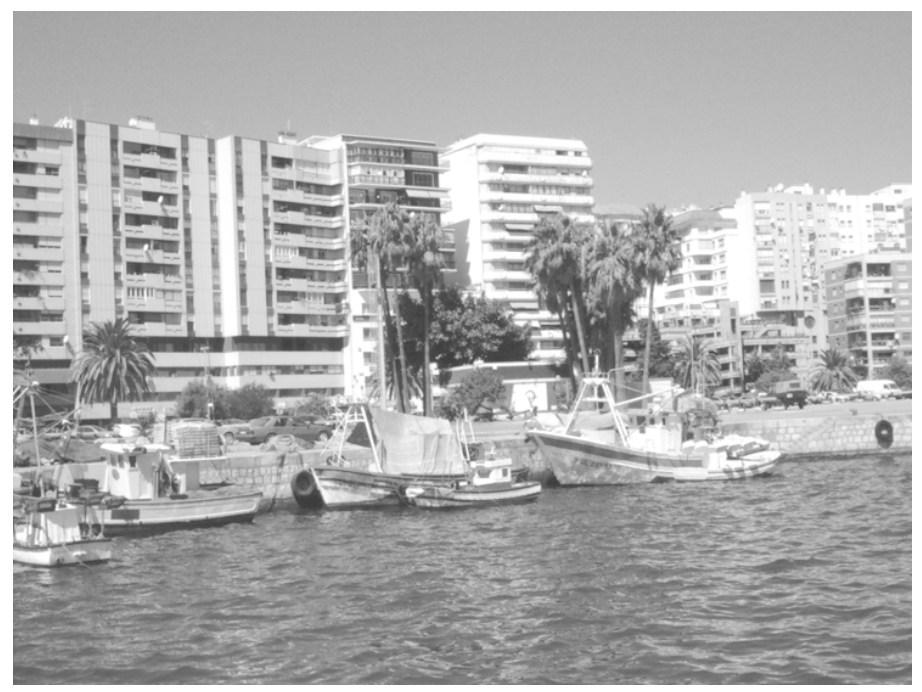

Fig. 1: Details of the Paseo Maritimo, where usually some fisher boat lie at anchor (photo: Carolin Alfonso)

Besides these commercial and financial activities, Algeciras has always been, and still is, considered a centre of a shadow economy and contra-

4 The administrative district encompasses Algeciras, Castellar, Gibraltar, Jimena, La Línea, Los Barrios, San Roque and Tarifa. 
band trade. While mainly alcohol and cigarettes were smuggled in the past, now rumours of illicit drugs and human trafficking are associated with the old port quarter around the market place Ingeniero Torroja.

According to the literature (cf. Driessen 2003), and confirmed by my interview partners, the city is characterised by an "air of transience". Algeciras is a place of transit with a strong port atmosphere: "El algecireño medio tiene un fuerte sentimiento de desarraigo" (Virgilio 10/08/2004). During my fieldwork, many Algecireños openly stated their perception of the city as being "fea, sucia y triste"6 and complained about the bad maintenance of public spaces (parks, plazas, streets etc.) and of the city in general. This holds true especially for the areas along the waterfront, although changes began with the revitalisation processes attempting to regain obsolete port facilities as public space.

\section{The old port quarter}

"Algeciras no se ha convertido en pueblo ni en ciudad, sigue siendo un asentamiento de contrabandistas, psicológicamente quiero decir, y ese espíritu lo sufrimos desde en nuestra administración municipal hasta en la estética de nuestras calles." (Virgilio, 10/08/2004)

Immediately next to the port, i.e. along the Paseo de la Conferencia, port-related businesses and institutions are located. They include customs, ship and cargo insurance companies, ship outfitters as well as the port authority ("Autoridad Portuaria Bahía de Algeciras - APBA") and the "Centro de Formación Portuaria".

The old port quarter, also named the zona baja ${ }^{8}$ is situated adjacent to the waterfront (Paseo Maritimo), whose most striking feature is its depleted aspect. Compared to the "upper area" of the city, the houses in this area are dilapidated and the zona baja is perceived as a dangerous "no-go-area" by local (Spanish) inhabitants, an image reiterated in the media coverage and travelling guides as well.

5 "The average algecireño has a strong feeling of uprootedness." (All translations from Spanish original to English by the author).

6 Hideous, dirty and pathetic.

7 “Algeciras hasn't developed neither into village nor city, it continues to be a settlement of contrabandists, in a psychological manner I mean, and we still suffer from that spirit way down from our municipal administration to the aesthetic of our streets."

8 Lower zone. 
"El centro se ha convertido así en ese lugar incómodo al que hay que ir cuando no queda más remedio. Apenas tres o cuatro calles y la plaza principal dan una sensación de modernidad, animación y pulcritud, el resto parece abandonado, cierran bares y abren inmobiliarias, cierran tiendas y abren bancos, se tira un edificio histórico y se levanta un bloque horrendo, que a veces se queda por terminar." (Marcos, 04/04/2003)

Abandoned old buildings, new buildings never finished and badlymaintained public space in the streets and squares characterise the image of this area. Several of my interview partners claimed this to be part of a municipal strategy, which prioritises new housing and office development, rather than restoring the zona baja, and prevents potential financiers from investing in this area. As a result, the area has become unfavourable for local businessmen as well.

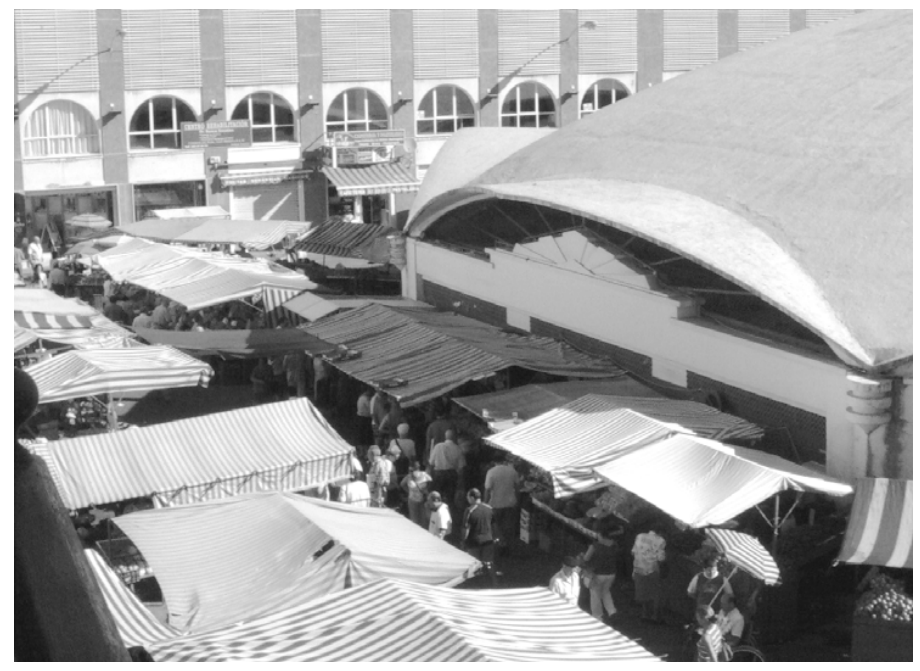

Fig. 2: The market place building Ingeniero Torroja surrounded by additional stalls (photo : Carolin Alfonso)

9 "This is how the centre has become an awkward place, to which to go when there's no remedy. Only three or four streets and the plaza central breathe an air of modernity, animation and tidiness, the rest seems to be abandoned, bars are closing and instead estate agent offices open up, shops are closing and instead a bank opens up, a historic building is torn down and a horrible multi-storey is being built, sometimes even never finished." 
The central market named after its constructor Ingeniero Torroja is located in the zona baja. Constructed in 1935, this building is famous as one of the most important works of Spanish architecture of the $20^{\text {th }}$ century and has become a local landmark for Algeciras. ${ }^{10}$ Algecireño merchants and inhabitants draw on this place as a symbol of local identity and pride, and it represents a shop window of Algeciras. The market consists primarily of fish and fresh produce stalls, and unlike its surroundings, the building and the stalls are well maintained. The building itself is surrounded by other stalls adding to the selection of fresh produce. Street vendors display their range of goods, mostly leather goods and cheap household articles. Most of these vendors are Spaniards, with a few Moroccans or Africans in between. Moroccan-run businesses are concentrated in the adjoining streets however, which are less attractive to Spanish investors and business interests.

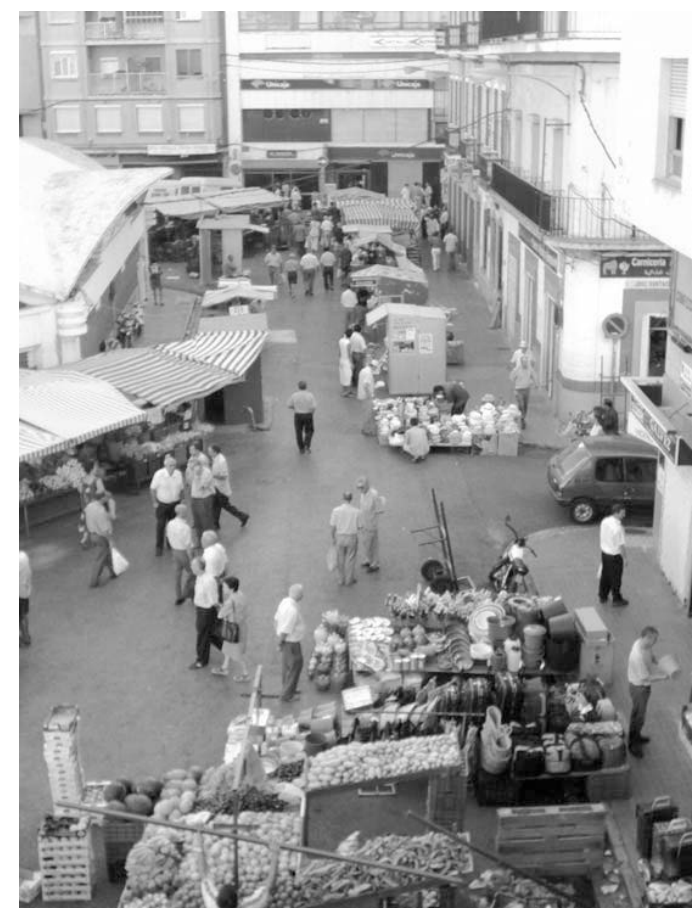

Fig. 3: Perspective on the market place on a weekday morning (photo: Carolin Alfonso)

10 A functional avant-garde work, it has an octagonal ground plan with no interior joist to support the ceiling. 
Except for the high season in summer, when the streets are crowded with ferry passengers waiting to cross the sea, Moroccan migrants are not strikingly visible in the general picture of the city. This might be due to the fact that most Moroccan (and other) migrants use Algeciras as a point of transit on their way to the major Spanish cities or to other countries of Western Europe. Pumares (2003: 189ff) alludes to this air of transience in his categorisation of migratory spaces in Spain and classifies Algeciras as a "border space". Because of its local geostrategical logic, Algeciras "es [...] un puente entre dos mundos que vive del flujo, del ir y venir entre ambos"11. (Pumares 2003: 189) ${ }^{12}$ This characterisation is somewhat confirmed - although with a negative connotation - by the statement of an informant: "Algeciras siempre se ha preocupado de que la gente se vaya y no que se quede"13 (Bhouziam 21/08/2004).

However, as Driessen (2003: 3) states, an increasing number of Moroccans have begun to settle down permanently. ${ }^{14}$ Along the way to the ferry terminals on the Avenida Virgen del Carmen (the Paseo Maritimo) there are plenty of ticket offices for the ferries to Ceuta or Tangiers, as well as small restaurants and fashion boutiques. Although there is no explicitly "Moroccan quarter" yet, nonetheless a process of appropriation of space is happening in the old port area. Here Moroccans are highly visible, especially on the Waterfront and in the streets around the market. The mosque is located here; young Moroccan men run Internet cafés and public telephone booths, as well as Moroccan bazaars selling fashion, leather goods and presents. Close by are groceries and halalbutchers, small restaurants, cafés and cheap hostels (hostales). Depending on the time of day, it is a lively shopping area characterised by ethnic businesses and the vibrant market activities, transforming into a more sombre mood in the evening hours.

11 "[...] a bridge between two worlds, which lives of the flow, the coming and going."

12 The other three spaces of his typology being agrarian spaces (insertion onto labour market with pre-industrial features), tourist spaces (hotel, catering and building sectors) and metropolitan spaces (highest concentrations of foreign population facing highly diverse incorporation into labour market) (Pumares 2003).

13 Algeciras always made an effort to see that people move on, and not that they stay put.

14 Generally speaking, Moroccan immigration to Spain remained low in numbers until the mid-1980s, considering Spain mainly as a transit country to e.g. France. This changed dramatically by the beginning of the 1990 s and nowadays Moroccans represent the main immigrant group in Spain (Aubarell 2004: 4; Mendoza 2001: 44). 
Lower rents in the run-down houses make the area affordable for migrants with limited economic means (Pumares 1996: 93ff; Martínez 1999). Besides economic aspects, Moroccans' access to housing is also limited by racist attitudes (Ribas-Mateos 2005: 132), which relegate them to dilapidated areas such as the zona baja.

This high concentration may be seen as indicator of an emerging ethnic infrastructure. Ethnic niches appear as a result of self-help and self-employment on the part of ethnic entrepreneurs (Kloosterman/Rath 2001: 194ff; Kloosterman/Rath 2003). Dense networks are not just part of an "imported" cultural practice, but at the same time an important basis of social organisation of Moroccan migrants in Algeciras. These networks help to recruit staff for businesses, providing socio-economic benefits for both parties involved, and furthermore offer protection and orientation in a new environment for newcomers. Such networks are characteristic of ethnic entrepreneurs and provide capital as well as employees (Mitchell 2003: 79; Light/Gold 2000: 94). In doing so, Moroccan migrants capitalise on their resources and oppose the limited local opportunity structures for business. By the appropriation of space in the waterfront and port areas, Moroccan migrants can rely on a dense transnational network of people and activities. Lately, a few Moroccanowned businesses have also opened in the "upper area" of the city, but this does not reach the density and presence of ethnic businesses in the port quarter.

Popular stereotypes of the area portray illicit drug-dealing, contraband and money laundering taking place there, cultivating an image of danger, which is also perpetuated in nearly all tourist guides. This image is intensified through vivid media coverage of complaints or infamous events, such as semi-hidden prostitution ${ }^{15}$ or conflicts between Spanish and Moroccan entrepreneurs (cf. Pérez 2004: 15).

\section{Revitalisation processes and relations between port and city}

While the port areas have remained dark, shabby and dilapidated for a long time, the City Council has recently joined forces with the port authority (APBA) and the Municipal Council of Planning ("Junta de Obras") to revitalise the waterfront and the neighbouring areas. These efforts were initiated in 2006 with the festivities celebrating the centen-

15 Low level prostitution is organised in low priced hostales surrounding the market place (Ribas-Mateos 2005: 107). 
ary of the International Conference of Algeciras, when history was evoked by exhibitions of antique photographs of the port, round table discussions, workshops and conferences focusing on the development of port-city relations (for detailed information see APBA 2005). One important achievement was the "creación de un programa de rehabilitación urbana de barrios con importante inmigración" "16 by the local authorities and associations of the Campo de Gibraltar. ${ }^{17}$ The area of the market place Ingeniero Torroja was especially scheduled for redevelopment, with plans for improving the pavement and illumination, as well as investments in more effective garbage collection and a higher presence of local police (García Iborra 2006). The most ambitious project however, is the Llano Amarillo, to let "[que] el mar vuelva de nuevo a penetrar en el gran Paseo Marítimo"18 (García Rojas 2006: 11) and bring about that "Algeciras vuelva a mirar al mar"19 (Ayuntamiento de Algeciras 2006: 14). The Llano Amarillo is a vast port area of more than $83,000 \mathrm{~m}^{2}$ situated on the Ribera quay of the fisher docks, which is planned to accommodate zones for leisure, commercial and sportive activities, as well as palm groves and a car park.

16 "Creation of a programme for the urban rehabilitation of quarters with important migration numbers."

17 Among others, the stated objectives of the ensuing rehabilitation programmes include:

"1. Conseguir una regeneración, mejora, refuerzo y potenciación, física y social, de los núcleos urbanos del área del Estrecho, con una especial atención a aquellas barriadas con una mayor densidad de población marroqui. (Achieve a regeneration, amelioration, reinforcement, potentiation, physically and socially of core urban areas of the Estrecho, with special attention to those quarters with a high number of migrant population.)

2. Disminuir la percepción de gheto, evitando el abandono de estas zonas por parte de la población autóctona, vertebrando física y socialmente los espacios urbanos con mayor densidad de dinámica migratoria. (Diminish the perception of ghetto, avoiding the local population to abandon those areas, forming a solid physical and social urban space in the areas with high migratory dynamics.)

3. Mejorar el espacio común, los equipamientos sociales y económicos y el mobiliario urbano. Tienen un carácter integrador en la zona de actuación. (Enhance the public space, as well as social and economic environment and the urban furnishing. They have an inclusionary character in the zones of action)." (Excelentísima Diputación Provincial de Cádiz)

18 "[that] the sea should penetrate the great Paseo Maritimo once again."

19 "Algeciras should be looking at the sea." 


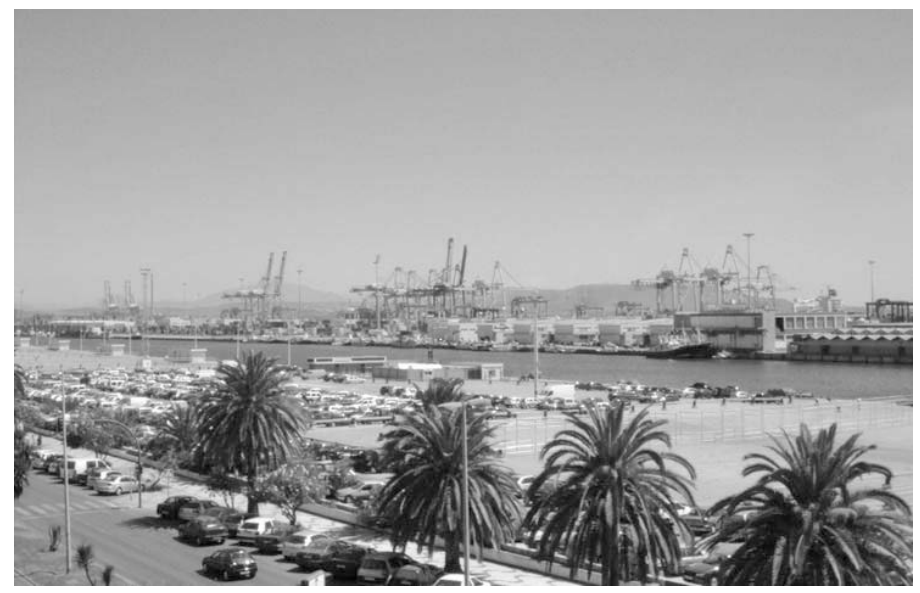

Fig. 4: Parts of the Llano Amarillo area with view to some port facilities in the back (photo: Carolin Alfonso)

The project aims at integrating this area into the unused spaces of the city and openly seeks to upgrade the maritime zone of the Waterfront. It is also intended to regain a $500 \mathrm{~m}$ wide area of the sea for an artificial beach, by relocating parts of the waterfront. This implies the removal of parking areas needed for shipping the vehicles of Moroccan migrants travelling home during the summers, which will be moved to another part of the city not so central. In addition, this project, which took off in autumn 2006 with a public invitation to compete for building development, seeks to connect with a project for revitalising the Rio de la Miel river, which - ironically - had been filled in decades ago in order to facilitate the enlargement of the port. By the way, this project has been named "El jardin de Umm Hakim",20, alluding to the Islamic history of the city.

\section{Conclusion}

Algeciras is a paradigmatic example of exclusionary features of globalisation manifesting themselves in the local, where everyday dynamics of exclusion become especially evident in the access to appropriate housing. Since the 1970s, Moroccan migrants have settled their businesses in the port quarter. Among other reasons were derelict housing and the resulting low rents. The former Algeciran population had left the area.

20 "The garden of Umm Hakim". 
They were followed by the so-called gitanos, who allegedly left the place even more deteriorated. The port quarter's image as unsafe and dangerous made the area rather unpopular for investors and local businessmen, whose commercial activities were eventually taken over by Moroccan entrepreneurs targeting their fellow countrymen.

Public space has been defined as "the common ground where people carry out their functional and ritual activities that bind a community, whether in the normal routines of daily life or in periodic festivities" (Carr et al. 1992: xi). I have elaborated on the market area to emphasise its different meanings, day-to-day activities and various perspectives. The market emerges as an important place for the identity of the Algeciran population as well as for the public image of the city. The market place with its adjoining streets serves to highlight the appropriation of space by Moroccan migrants, who recur to social networks for ethnic entrepreneurship, preserving cultural practice based on solidarity networks.

Ostensibly the port quarter still remains run-down, but this perception does not hold true on closer examination. Given that the area was extremely neglected before the influx of Moroccan migrants, today in comparison the area offers vibrant commercial activities. Although illicit trade and camouflaged activities are supposed to take place there, all my interview partner agreed that an upgrading of the area has become increasingly visible. This process is far from concluded, and has received new impulses "from above" through the initiatives of the City Council and the Port Authority, as exemplified by the Llano Amarillo and the urban rehabilitation projects. In summary, the development of the old port quarter from a formerly well-off area, later inhabited by gitanos who were followed by Moroccan migrants and back to a proposed zone of urban leisure and consumption, represents an example of gentrification processes of the "invasion-succession type" (cf. Smith 1979; Ley 1986; Dangschat 1988; Hamnett 1991). It remains to be seen how plans aimed at bringing back the city to the waterfront will further affect the old port quarter and its local actors.

\section{References}

Aubarell, Gemma/Aragall, Xavier (eds.) (2003): Migración y desarrollo. Estudio de dos casos particulares: Ecuador y Marruecos, Madrid: Centro de Estudios de Cooperación al Desarrollo (CECOD).

Autoridad Portuaria de la Bahía de Algeciras - APBA (ed.) (2005): Centenario de la conferencia international de Algeciras y la junta de 
obras del puerto, Algeciras: Autoridad Portuaria de la Bahía de Algeciras.

Autoridad Portuaria de la Bahía de Algeciras -APBA (ed.) (2006): Memoria anual 2005, Algeciras: Autoridad Portuaria de la Bahía de Algeciras.

Ayuntamiento de Algeciras (ed.) (2006): "Llano amarillo. Algeciras vuelve a mirar al mar”. Algeciras Hoy 1, p. 14.

Carr, Stephen/Francis, Marc/Rivlin, Leanne G./Stone, Andrew M. (1992): Public Space, Cambridge: Cambridge University Press.

Dangschat, Jens S. (1988): “Gentrification - Der Wandel innenstadtnaher Wohnviertel”. In: Jürgen Friedrichs (ed.), Soziologische Stadtforschung. Sonderheft 29 der Kölner Zeitschrift für Soziologie und Sozialpsychologie, Opladen: Westdeutscher Verlag, pp. 272-292.

Driessen, Henk (2003): Preliminary Report: Enclavement of Moroccan Immigrants in the Port City of Algeciras, unpublished manuscript.

Excelentísma Diputación Provincial de Cádiz, Diputación de Cádiz (http://www.dipucadiz.es/iedt/maarifa/impActividades/impActividad .asp?ID=83) [09/07/2006].

García Iborra, Elisabeth (2006): "La generación del imposible. Algeciras, frontera de Europa”. El Dominical 09/06/2006.

García Roja, Rafael (2006): "Algeciras: Ciudad de centenarios". UCAmpus - Revista de la Universidad de Cádiz 1, pp. 11-14, (http://www.uca.es/web/organizacion/equipo_gobierno/dgcri/comuni cacion/revista) [01/09/2007].

Hamnett, Chris (1991): "The Blind Man and the Elefant: The Explanation of Gentrification". Transactions of the Institute of British Geographers 16 (2), pp. 173-189.

Hoyle, Brian (1988): "Development Dynamics at the Port-City Interface”. In: Brian S. Hoyle/David A. Pinder/M. Sohail Husain (eds.), Revitalising the Waterfront. International Dimensions of Dockland Redevelopment, London: Belhaven Press, pp. 3-19.

Kloosterman, Robert/Rath, Jan (2001): "Immigrant Entrepreneurs in Advanced Economies: Mixed Embeddedness Further Explored". Journal of Ethnic and Migration Studies 27 (2), pp. 189-201.

Kloosterman, Robert/Rath, Jan (eds.) (2003): Immigrant Entrepreneurs. Venturing Abroad in the Age of Globalization, Oxford et al.: Berg.

Ley, David (1986): "Alternative Explanations for Inner-City Gentrification”. Association of American Geographers 76 (4), pp. 521-535.

Light, Ivan/Gold, Steven J. (2000): Ethnic Economies, San Diego: Academic Press.

Martínez Veiga, Ubaldo (1999): Pobreza, segregación y exclusión espacial, Barcelona: Icaria. 
Mendoza, Cristóbal (2001): “Cultural Dimensions of African Immigrants in Iberian Labour Markets". In: Russell King (ed.), The Mediterranean Passage. Migration and New Cultural Encounters in Southern Europe, Liverpool: Liverpool University Press, pp. 41-65.

Mitchell, Bruce (2003): “The Role of Networks Among Entrepreneurs of Different Ethnic Groups”. The Small Business Monitor 1 (1), pp. 78-88.

Nohlen, Dieter/Hildenbrand, Andreas (eds.) $\left(2005^{2}\right)$ : Spanien. Wirtschaft - Gesellschaft - Politik. Ein Studienbuch, Wiesbaden: Verlag für Sozialwissenschaften.

Pérez, Rosario (2004): "Vecinos de la zona baja se quejan del deterioro cultural”. Europa Sur (18/08/2004).

Pumares, Pablo (1996): La integración de los inmigrantes marroquíes, Barcelona: Fundación 'La Caixa'.

Pumares, Pablo (2003): "La inmigración en España: Perspectivas desde el territorio". In: Gemma Aubarell (ed.), Perspectivas de la inmigración en España, Barcelona: Icaria, pp. 177-204.

Ribas-Mateos, Natalia (2001): Revising Migratory Context: The Mediterranean Caravanserai. In: Russell King (ed.), The Mediterranean Passage. Migration and New Cultural Encounters in Southern Europe, Liverpool: Liverpool University Press, pp. 22-40.

Ribas-Mateos, Natalia (2005): The Mediterranean in the Age of Globalization, New Brunswick: Transaction Publishers.

Smith, Neil (1979): "Toward a Theory of Gentrification: A Back to the City Movement by Capital not People". Journal of the American Planning Association 45 (4), pp. 538-548. 



\section{Belém, "Gate of Amazonia" - Port and River as Crossroads}

\section{ROSEMARIE AND DIRK OESSELMANN}

The geopolitical importance of Belém, the capital of the Brazilian Federal State of Pará, lies above all in its function as "Gate of Amazonia" (Wagner 1996: 21; Campos 1997: 105). Even today, it is still isolated from the rest of Brazil, due to the immense distances to the nearest cities (São Luis $748 \mathrm{~km}$, Fortaleza $1500 \mathrm{~km}$, Brasília $2036 \mathrm{~km}$ ) and to the restricted means of transport. Apart from travelling by plane, which is expensive and rather limited, these distances have to be covered by bus (to the Northeast or to Brasília) or by boat (to Amazonia). These journeys take days or even weeks. When going to the Amazonian interior, boats are the only alternative to small planes. In view of this situation, port and river take on an outstanding importance.

Belém, a city with more than a million inhabitants, is situated in the estuary of the river Pará, encompassing $718 \mathrm{~km}^{2}$, more than half of which consist of mostly uninhabited islands (Matos 2003: 111). As is the case in most parts of the rain forest, the area in which the city developed is broken up by a number of small rivers, brooks and channels which flood the adjoining quarters at high tide or with heavy rain. Even today, this separates the city into two districts: dry (expensive) living quarters which are relatively secure from water, and so called baixadas, slum areas which are regularly flooded. ${ }^{1}$ This difference corresponds to a social separation, also evident in the port systems.

On the one hand, there is the international port. Belém gives access to the most extensive river system on earth and thus to the riches of the

1 Conditions in the baixadas will be described more closely, taking the district Guamá as an example. 
Amazonian rain forest. These can be exploited, transported via the rivers to the international port of Belém and then exported abroad. As a starting point, this port is above all orientated outwards and thus liable to lose importance with decreasing numbers of goods or the shifting of outside interests.

On the other hand, there are the small river ports. The river and its many, partly informal port facilities are vital for the native population as destinations of transition from the interior to the city and as the only access to markets and means of information and communication.

Rosa Acevedo Marin observes that Belém with its trapiches ${ }^{2}$ represents the dreams of those who come to the city from the interior. The arriving boats touch the city, but the differing ways of life remain, linking the culture of those arriving to that of those moving around in the port area. Port and trapiches help to understand the networks of people living in worlds which touch and at the same time remain different (Marin 2003: 79)

This article investigates the movements around the port area in history as well as recent changes, and the economic, social and cultural consequences for the development of the city and the living conditions of people arriving and settling there. A focus lies on the processes of change and their effects on the local population, using as an example the Centro Histórico ${ }^{3}$ in its historical development as well as the present situation. The tensions of an environment which is characterised by rural exodus and social inequality are also concentrated in the area of port and river, as interviews with members of a youth gang illustrate.

In the following chapters, the stages in the history of Belém which give different meanings to port and river are described, starting with the foundation of the military base and the development of the first urban area. Increasing international trade led to port extensions, whereas the changed situation at the end of the $20^{\text {th }}$ century necessitated structural as well as administrative reforms. Processes of social change, closely related to the geographical conditions, caused the development of two distinctly different urban areas. This was intensified due to rural exodus and migration to the city. Finally recent developments are discussed in detail.

The article is based on literature mainly published in Brazil, a report on a research project in the Centro Histórico (2003), interviews with the members of a youth gang in the district Guamá (2003) and on the authors' personal observations.

2 Trapiches are small wooden landing stages on both sides of the river.

3 Historical centre. 


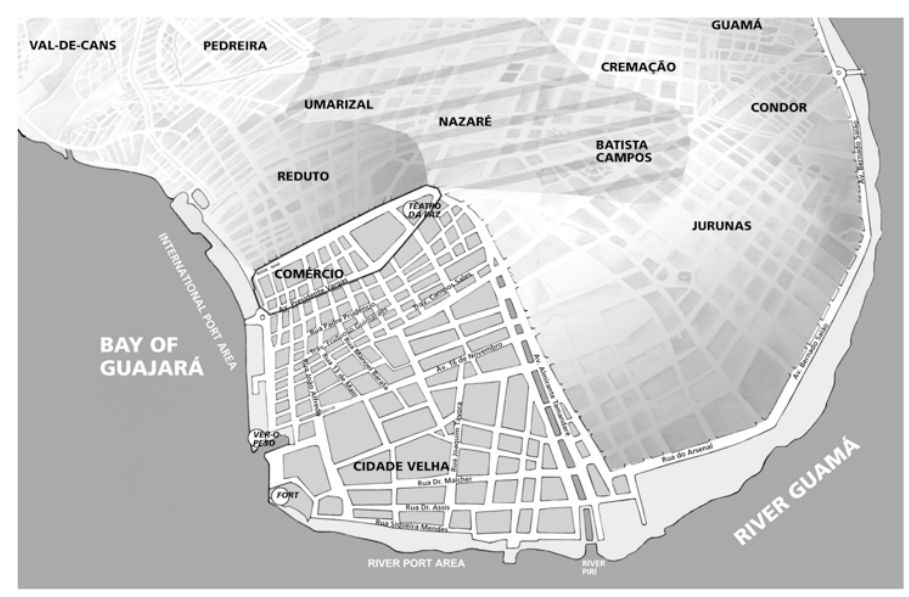

Fig. 1: Segment of Town Map: In the foreground Cidade Velha, first urban nucleus; Comércio (originally Campina), since the $17^{\text {th }}$ century zone of commerce, connecting directly to the international port area. Together with Cidade Velha, it forms the Historical Centre (Centro Histórico) of Belém. Umarizal, Nazaré, Batista Campos: Extension of the zone of commerce. Dry urban area for high income groups and international elite. Reduto: Living quarters of dock workers; Jurunas, Con-dor, Guamá: Low lying, regularly flooded area (baixadas), mainly inhabited by migrants from the interior - area of social conflicts (Marthe Schaar)

\section{From military base to urban settlement}

Belém was founded in 1616 by the Portuguese colonial power as a fort for the protection of the Amazon estuary and the access from the south and north, particularly against the Spaniards and French in the vicinity and also to protect the area against French, English and Dutch pirates (Kohlhepp 1986: 11; Enciclopédia 1996: 106). The natural barrier to the mainland caused by the regularly flooded small river Pirí (Igarapé Pirí de Jussara) added to the favourable defence situation (Lopes/Coelho 2003: 63). Belém became a point of departure for expeditions into the interior and for further foundations such as Fort Óbidos (Wagner 1996: 15).

The port of Belém, also dating back to 1616, started as a simple anchorage ground, $120 \mathrm{~km}$ away from the open sea on the bay of Guajará and the river Guamá, giving direct access to the Amazon river system. 
The protected situation of the port initially was advantageous, whereas this aspect later lost importance due to the development of navigation of bigger ships (Penteado 1973: 29).

A path was built in 1621 along the river Guamá towards the military base (Rua do Norte, today: Rua Siqueira Mendes). From here the first urban nucleus (Cidade, today: Cidade Velha ${ }^{4}$ ) developed as a political, military and religious centre. During the next two decades three parallel roads followed which touched the marshland of the river Pirí in the east. In the course of the $17^{\text {th }}$ century, cross-roads were built which connected the river Guamá with the marshland. A Carmelite convent, founded in 1624, supported colonisation of the interior.

Interest shifted to the bay of Guajará, when a road was constructed in 1627, connecting the port with the convent of St. Antônio and extending the area westwards. This became a trade route and an axle along which a zone of commerce developed (Campina, today: Comércio). Until the end of the $17^{\text {th }}$ century, the anchorage served as port of the city (Penteado 1973: 48).

Cidade Velha and Campina which together formed the Centro Historico of Belém, were separated from the mainland by the small river Pirí. Due to the tides, regular flooding restricted exchange, which mostly took place via a number of wooden anchorages (trapiches). Based on a plan submitted by the engineer Gronfelts in 1771 and realised by order of the governor of the state of Pará in 1803, the river Pirí was drained and filled up, thus overcoming the separation of Cidade Velha and Campina (Penteado 1973: 51f.). The Avenida Almirante Tamandaré is in its place today.

\section{International trade and port extension}

The developing population nucleus suffered from isolation. Trade connections with Europe existed exclusively via Lisbon. The situation in the emerging locality was precarious, particularly owing to duty payments on waterways and boats (Penteado 1973: 48ff.).

As early as 1743, however, Belém was regarded as a "big city" with regular trade connections with Lisbon. Goods arriving from Europe were bartered for local products such as gold dust, cloves, vanilla, sugar, coffee and, above all, cocoa. As the hinterland of Belém supplied the goods which were exchanged for European imports, the future of the city was secure. It developed from an exchange station into an important trade

4 City resp. Old City. 
centre and established itself as export and import site. The ships arriving from Europe moored in the bay of Guajará north of the river Pirí, the riverboats directly at its mouth, where the actual city port of Belém was situated for a long time (Penteado 1973: 51).

In the second half of the 19th century, river navigation was intensified in Amazonia. Companies were founded which erected a number of small quays on both sides of the river Guamá and further up on the bay of Guajará which still exist today, promoting trade and passenger traffic of the inland population to Belém (Penteado 1973: 60).

The first steamship belonging to one of these companies left the port in 1853, opening the river route to Manaus which at first operated once a month, from 1854 onwards twice monthly. In 1867 several smaller companies were set up. In 1874 the two main companies merged into the Amazon Steam Navigation Company which then held a kind of monopoly. The port of Belém extended its influence, navigation increased considerably (Penteado 1973: 60).

Different regions of the Amazonian interior provided - and still provide - products for the port and city of Belém. The immediate hinterland, encompassing the city itself as well as the adjacent area of Bragantina, is important both for the import and export of goods. The main products of this region are black pepper, fibre and cement, either for local use or for export to other Brazilian states or abroad. The near hinterland can be reached by regularly operating river boats in up to six days' time. Ships to the far hinterland run once or twice per month and often only at three months' intervals. The main products exported are rubber, Brazilian nuts, diverse seeds as well as wood, fish-glue, hides and furs. Imports into this region are negligible, as the population density is extremely low (Penteado 1973: 135ff.).

From 1860 onwards, exports of rubber (caoutchouc) collected in the Amazonian rain forest increased rapidly. Until 1890, however, there were neither port facilities which could cope with this increase nor an adequate organisation. In the last decade of the $19^{\text {th }}$ century, the federal government took matters in hand. Rubber, which had brought many advantages to Amazonia, helped Belém develop into a port adequate for its economic importance (Penteado 1973: 60).

The extension of the port of Belém began when Amazonia was the most important world-wide rubber producer, with a large modern river fleet at its disposal, dealing with internal transport. Demand increased still more as a consequence of the development of new, diverse rubber manufacturing industries in the industrial centres of Europe and Northern America. As a result, prices reached dizzying heights on the interna- 
tional market, and the Amazonian capitals - Belém and Manaus - profited from the capital flow (Pinheiro 1996: 45f.).

Before the construction of the new quay, loading and unloading of goods as well as passenger traffic from and into the interior had taken place via the various trapiches, which were mostly only suitable for small motorboats called gaiolas 5 . Larger ships for coastal shipping operated via the Trapiche Lloyd which was deeper. There also existed the Trapiche Auxiliar directly in front of the fish market, where small cargoships moored. Ships with higher tonnage transporting overseas goods anchored further away in front of Pinheiro village (today: Icoaraci) or in the bay of Guajará. Their goods were reloaded and later discharged at the storage shed near the custom house (Pinheiro 1996: 46f.).

During 1910/12 the rubber cycle started to decline. Although compensation could be realised by exporting oleiferous seeds, the economic importance of Belém decreased visibly (Penteado 1973: 88).

In 1940 the federal government put practically all port institutions under state government and ownership (Pinheiro 1996: 47). From 1967 onwards, the port's status steadily declined which led to a reduction of labour. Part of the docks fell into decay. The main cause of this development was inadequate organisation in the port itself and in the transport of goods from the interior (Penteado 1973: 225ff.).

Based on the assumption that the Amazon as well as Belém would still have central importance, an orientation away from port and river in order to find ways of connecting with the rest of Brazil could be observed for a relatively short period. The proposed railway-line from Rio de Janeiro to Belém has to be seen in this context. It has never been built, but since the beginning of the 1960s, there exists a highway connecting Belém with the federal capital Brasília, which mirrors the same idea (Penteado 1973: 233).

In the course of internationalisation, the port facilities were divided into two areas: One was exclusively orientated towards international trade, the other one towards river traffic and local trade. This clearly demarcated division intensified the social and cultural segmentation of the city, as the native, lower class population was denied access to the international port as well as to any economic advantages connected with international trade. These aspects will be discussed in a later chapter.

5 Literal translation: cages. 


\section{The port at the end of the $20^{\text {th }}$ century}

At the end of the $20^{\text {th }}$ century, river traffic in Pará was and still is busy, connecting with hundreds of ports of different sizes. The majority of these have only limited capacity and are used for transporting people and goods between settlements along the rivers. Only the ports of Vila do Conde, Miramar, Belém and Santarém as well as privately run terminals are qualified for overseas traffic (Pinheiro 1996: 53).

Belém, although ranging behind Vila do Conde and Miramar, is still very important in the region owing to the diversity and economic value of its freights. After the end of the Brazilian "economic miracle" in the 1980s, Belém had faced a break-up of the port activities caused by lack of state investments. Diversification became necessary, which led to exports of a variety of extraction products and processed products for different industrial and trade sectors (Lopes/Coelho 2003: 64).

Also of advantage were a number of characteristics such as urban infrastructure with easy access to electricity, means of communication, commercial activities and varied means of transport. The equipment of the port of Belém, however, was not satisfactory as most of it was technically outdated and due to natural wear in need of extensive repairs. As a consequence, structural as well as administrative reforms were vital to make the port attractive for modernising investments (Pinheiro 1996: 54f.).

These reforms followed three principles: The first step was the withdrawal of the public authorities from the administration of the port. This aimed at increasing productivity and lowering of costs by means of free competition between private enterprises. The Companhia Docas do Pará $^{6}$ contacted 18 private firms who have already taken over the service sector at much lower cost. The Companhia, however, still retains its influence by fixing maximum prices in order to avoid cartel agreements which would result in increased costs. To represent the interests of the employees, the Sindicato dos Operadores Portuários no Estado do Pará was set up and authorised to negotiate between management and port workers (Pinheiro 1996: 56).

Secondly, the crisis between capital and labour had to be overcome. The reason for this crisis dates back to the beginning of the 1930s, when work in the port was physically exacting and the productivity of a worker was not higher than 20 tons per day. Over time, this productivity was increased up to 1000 tons per day due to technical equipment such

6 Society for the Docks of Pará.

7 Trade Union of Dockworkers in the State of Pará. 
as fork-lift trucks, conveyer belts etc. Although through this development much manual labour became obsolete, the number of workers remained constant, resulting in excessive costs which reduced successful competition (Pinheiro 1996: 57).

To solve this problem, the organisation $\mathrm{OGMO}^{8}$ was set up. It represents both port managers and workers and is responsible for management and control. This is to guarantee the correspondence of labour, expenses and professional efficiency. The OGMO has already considerably reduced the number of port workers, at the same time setting up a fund for persons made redundant, thus stimulating voluntary retirement.

The third step was modernisation through private investments. The legislative passed a law, originally named "Law for the privatisation of ports". After intervention by the trade unions this was altered to "Law for the modernisation of ports". Although the government is determined to implement this law, it is necessary to do this on the basis of careful and thorough analysis of the given situations and to act accordingly (Pinheiro 1996: 60).

\section{Processes of social change}

During the $18^{\text {th }}$ and $19^{\text {th }}$ centuries, the Cidade Velha was the first urban area in Belém to be developed into a central place for public and private life for the Amazonian native population who arrived via the small anchorages. In due course, the concentration of commercial and service industries as well as the possibilities of transport and communication through direct contact with the small river ports had attracted further enterprises. This resulted in a wide choice of formal and informal labour, yet a coexistence of housing and business characterised this area for a long time (Ravena et al. 2003: 52).

Parallel to this, the zone of commerce connected to the international port had been visibly extended in the $19^{\text {th }}$ century with warehouses, banks and living quarters for higher income groups, with parks and central places (Praça da República). Beyond that zone, a new district of living accommodation for dock-workers had emerged (Redouto). Further development was brought about by Moroccans, Syrians, Lebanese and Jews who had immigrated into Belém since 1879 (Benchimol 1998; Cruz 1958; Zaidan 2001) and soon organised and dominated trade, mod-

8 Orgão Gestor de Mão-de-obra = Institution for the Management and for Manual Workers. 
ernising the city according to international standards. This modernisation concentrated on the new zone of commerce in the higher and therefore dry urban areas (Nazaré, Batista Campos and Umarizal), connected by a corridor to the international port, leaving aside the Cidade Velha and most of Campina. In extension of this zone, a new cultural centre emerged (Praça da Republica with Teatro da Paz) ${ }^{9}$, which had no direct access to the Cidade Velha.

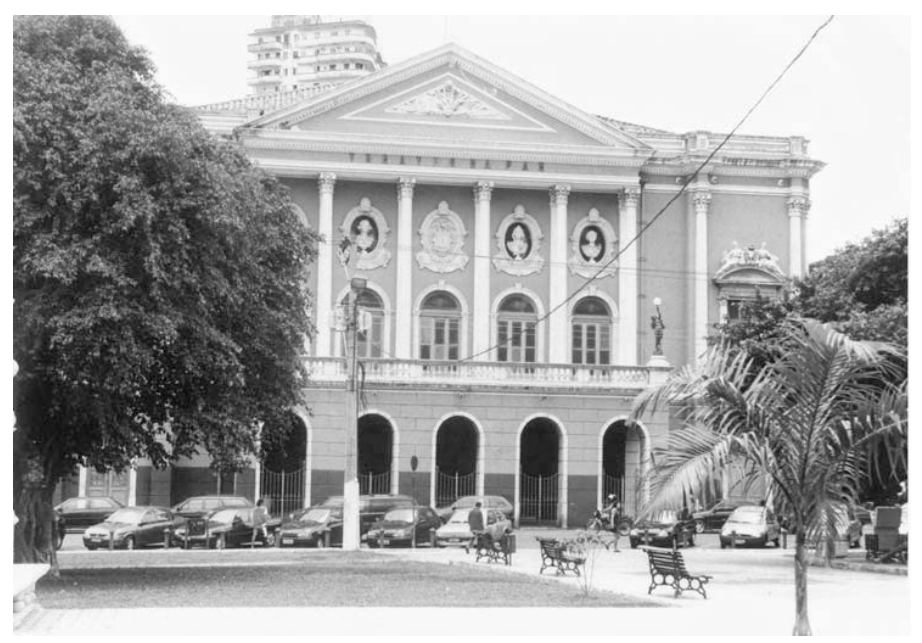

Fig. 2: Teatro da Paz (photo: Rolf Oesselmann)

Meanwhile, the expansion of trade caused families with high or medium incomes to move away from the Cidade Velha, above all because of increasing noise and the gradual deterioration of the buildings. Consequently, vacant accommodation was occupied by lower income groups, which led to a devaluation of housing property. The result was an area in the immediate vicinity of the centre which largely consisted of dilapidated buildings which, besides living accommodation, housed bars, cheap hotels, brothels and similar establishments. Even more of the higher income population moved away due to the increasing number of cars and unsatisfactory parking conditions caused by narrow streets and the absence of garages, resulting in a further devaluation of housing property.

9 "Square of the Republic" with "Theatre of Peace". The theatre was erected during the rubber boom and restored a few years ago. The Praça da Republica is the central square of the city. 
However, the centre was still used by higher income groups for work, shopping or services, but as the situation became yet more difficult, they preferred shopping centres and areas specialising in higher quality goods and services. The gradual abandonment of the centre by those consumers precipitated the decay and sub-use of buildings. Demand and supply were restricted to goods and services for low consumption, itinerant and other trade of the informal economy predominated (Ravena et al. 2003: 52).

Parallel to the deterioration of the Cidade Velha, the commerce zone connected with the international port (Nazaré, Batista Campos, Umarizal) developed more and more into an area reserved for high income groups and the international elite. This social division was emphasised even more when internal migration from the interior of Amazonia to Belém began on a larger scale in the $20^{\text {th }}$ century.

\section{Internal migration/rural exodus}

Although, from the very beginning, Belém was important for the rural population as a central place, there was no significant migration to that city. However, from the middle of the $20^{\text {th }}$ century onwards, this changed rapidly. The ruthless exploitation of the resources of the rain forest had worsened the economic situation of the native population. In addition, isolation, poor medical care and hardly any possibilities of education in the vast expanses of Amazonia had created an image of the city as a place where everything seemed possible. The rural exodus applied to migrants from the Amazonian interior and other regions, who mostly arrived by boat via the river ports in the immediate vicinity of the Cidade Velha where they had their first urban contacts.

At first, many of them settled there or in Campina, both of which consequently degenerated into areas of low consumption. As the population pressure grew, the Cidade Velha became a place of transit to districts further along the periphery (Jurunas, Condor, Guamá). This also resulted in settlements of wooden huts on posts in the baixadas, located further away following the riverside.

Based on a research in 2003, Ana Claudia Cardoso compares what she calls "centre", mainly located in dry areas, and "periphery", in this case the baixadas. ${ }^{10}$ She contrasts the respective living conditions on the

10 The extensive discussion on Centre and Periphery cannot be followed up in the context of this article. In accordance with Ana Claudia Cardoso, these terms will be used here in their geographical and social connotations. 
basis of income, accommodation, education facilities, public services and infrastructure. In the "centre" people live on regular incomes, their homes are exclusively used as housing and living space, education facilities are within walking distance. Public services, the supply of electricity and water are satisfactory and roads are asphalted. In contrast to this, people on the "periphery" live on irregular incomes, their houses are used to secure and supplement their earnings. ${ }^{11}$ As a rule, schools are at a considerable distance, transport is unsatisfactory and the drop-out rate is high. There are hardly any public services; supplies of water and electricity often break down. As these areas are regularly flooded, there is no drainage (Cardoso 2003: 39).

The district Guamá, directly situated along the river and today the biggest settlement of migrants from the interior, can be taken as an example of living conditions on the "periphery". The first settlements in the area were hospitals and cemeteries for lepers, that is for groups of the population who were expelled from the actual city. In the course of migration pressure these were gradually closed. According to the census of 2000, the population density in Guamá was the highest in the whole city, numbering 102,000 inhabitants.

At no time was there any political planning for the settlement of this area. Electricity, water, drains and public services for education and medical care were only then installed, in a piece-meal manner, when "the volcano was ready to erupt" (Oesselmann/Ferreira/Garcia 2006). Even today, the supply of education and medical facilities is insufficient.

The average family income lies between one and two "minimum salaries" family" can rely on fixed wages (Censo 2000). Mothers and children at an early age have to help with the family income. The proximity of the river is advantageous for drug traffic, as there is no policing of the transport system.

The majority of the immigrants come from the Amazonian interior, where rivers are part of everyday life. In Belém, as a result of social pressure, these people live in wooden huts on posts alongside or even above rivers and canals. They use the water for bathing, washing laundry and often for drinking. The result is a high incidence of illnesses, such as skin-diseases and diarrhoea (Matos 2003: 112).

11 See in detail Oesselmann/Oesselmann 2006.

12 The "minimum salary" (salário mínimo), introduced in 1936, was meant to cover the needs of a family of four persons. Today, with the considerably diminished purchasing power of the "minimum salary", this claim cannot be upheld. 


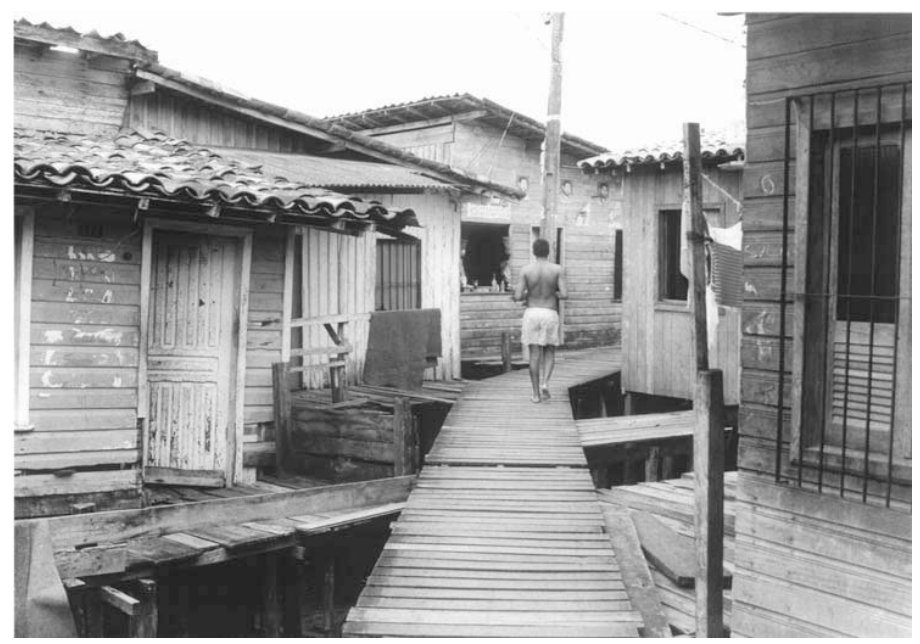

Fig. 3: Baixada (photo: Rolf Oesselmann)

The living conditions in the baixadas, as well as the severance of traditional social networks which had been important in the interior, have negative effects particularly on the adolescents who by now have organised themselves in more than 120 youth gangs. Although there is a high potential of violence among them, these adolescents are also, in many ways, victims of the destructive surroundings and life conditions, as a research project carried out in 2003 shows.

Of the twenty members of a youth gang between the ages of 17 and 22 who were interviewed, $75 \%$ complained about violence in the family caused, above all, by alcohol, bad housing conditions and stress. They further stated that due to the negative atmosphere in their families they had no chance to concentrate on education. In addition, the schools themselves were just as disastrous as their homes, as they provided no motivation and gave no help. The violence of the social climate not only dominates the families but also life at school and on the streets.

Membership in the youth gang provides the interviewed adolescents with a space where they feel accepted and safe within a larger group. A third of them are still trying to get on through education. But they know quite well that in their situation it will be extremely difficult to finish school at any level. They perceive religion and the street culture HipHop as alternative perspectives for themselves. $25 \%$ just want to get away and only $30 \%$ believe that they will eventually have an acceptable job (Oesselmann/Ferreira/Garcia 2006). 
In spite of these precarious conditions in the settlements along the river and in other regularly flooded areas, there are quite a number of cultural events which have their roots in the inland tradition - such as festivities in honour of saints, carnival groups ${ }^{13}$, theatre and music. Another factor are small religious parishes of Roman Catholic, "traditional Protestant"14 and Pentecostal Churches which people find in their vicinity. Here immigrants are not only given room for first social contacts but also assistance with problems of all kinds and the possibility of being actively engaged in various networks. This is particularly important as, on first contact, many migrants from the interior experience their new surroundings as unfamiliar and not in accordance with their expectations, in some cases even threatening, and need time to get used to them (Oesselmann 2000: 105f.; 123ff.).

The comparison of life in the "centre" and on the "periphery" demonstrates the differing social conditions in the areas connected to the international port on one hand and to the river on the other.

\section{The Cidade Velha today}

At the beginning of the $21^{\text {st }}$ century, revitalisation of the historical centre was put on the local government's agenda. A number of strategies for improving the housing situation were put into action, based on the assumption that it would be possible to preserve the area, as a considerable part of the urban population had remained there and had refused intraurban migration (Ravena et al. 2003: 52). In the end, these efforts more or less failed due to immense costs.

In the course of a research project by Nirvea Ravena and Voyner Ravena Cañete, carried out in 2003, the inhabitants of the Cidade Velha were questioned on their living conditions. The findings showed that their present social profile places them in the lower middle class. The family income amounts to between $\mathrm{R} \$$ (reais) 200 and $\mathrm{R} \$ 3,000$ (approximately 80-1,100 €) (Cañete et al. 2003: 28). The authors conclude that on one hand there is no immediate danger of poverty; on the other hand the average income is not sufficient for investing into the domestic infrastructure. This has already led to a slow decay of the historical buildings.

13 Such as bloco de fome ("hunger group" who, in fun, invade houses and eat any food they find) or Boi Bumba (figure of huge dancing ox).

14 Lutherans, Anglicans, Methodists, Baptists who often work together on the local level. 


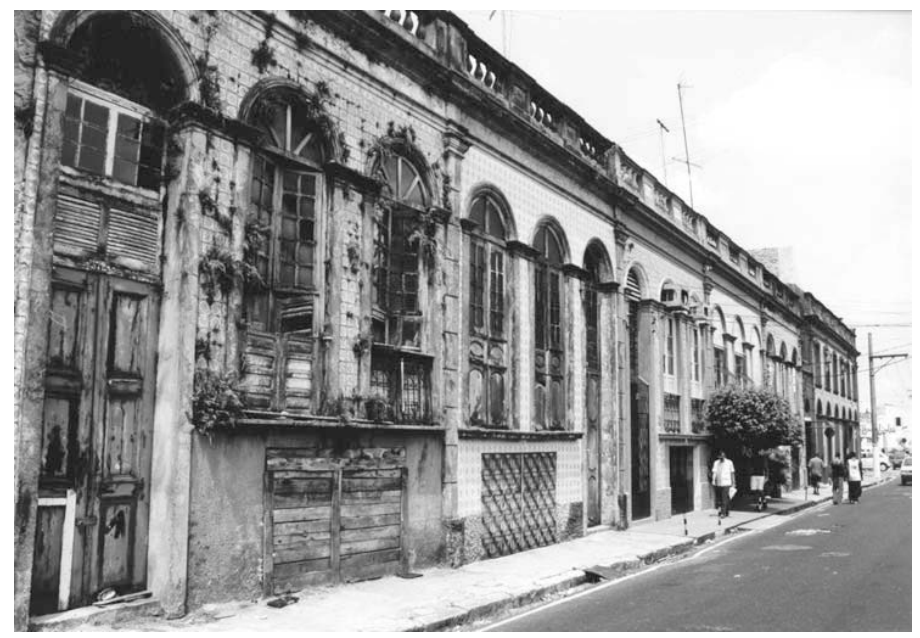

Fig. 4: Restored and dilapidated houses in the Cidade Velha (photo: Astrid Wonneberger)

There is continuous movement of persons and goods in the area of the river ports. People are not only arriving to stay but going back and forth, bringing local products from the interior, visiting their relatives and friends and taking back articles bought in the district, mainly the Ver-oPeso $^{15}$. This is seen by the inhabitants of the Cidade Velha as advantageous for activities of the informal sector, but also for other trade, as it stimulates business. Connected herewith, however, is the problem of safety. There is a high rate of fighting and assaults, often under the influence of alcohol. Between 50 to $70 \%$ of the shopkeepers and other local inhabitants rank safety as "bad" or "very bad" (Ravena et al. 2003b: 32). This is one of the most important reasons why $64 \%$ no longer want to stay in the area. Another reason is that the inhabitants feel separated from the rest of the city due to unsatisfactory transport facilities - a number of buses no longer run there - and the lack of cultural events (Cañete et al. 2003: 92).

However, some cultural events still take place in the Cidade Velha, above all the Círio de Nazaré, the biggest religious procession in Amazonia, where hundreds of thousands of people from the inland meet and celebrate the second Sunday in October. ${ }^{16}$ Many arrive days before the

15 Biggest market in the region. The name means literally translated: Watch the weight.

16 An elderly woman told us that, as every year, she had come from the interior by boat, a journey of about ten hours. In the procession she walks for 
big event, sleeping with family and friends or in the parks. The inhabitants of Belém prepare special meals ${ }^{17}$ which are shared in the neighbourhood. The Círio is advertised as a tourist attraction ${ }^{18}$, but as the whole area is literally packed with people singing, praying and following the procession, tourists can only safely watch the proceedings from a distance. The district is sometimes also described as the living quarter of intellectuals and artists. But as it remains the destination of internal migration and is still characterised by social conflicts, it is avoided by upper classes and tourists.

\section{Revitalisation of historic sites, Ver-o-Peso and river bank}

Access to the river system as means of communication, transport and survival strategies is still seen as of central cultural value even for the majority of the urban population. In the 1990s, however, it became evident that due to uncontrolled development of industry and trade, the population had practically no access to the river. The banks were completely occupied by port facilities which were mostly no longer used, as the enterprises which had owned them had long since moved away. In the end, the local authorities took up revitalisation of the riverside and gradually developed limited areas into a public promenade.

Even here the social division is evident. Revitalisation efforts for the port areas are initiated by different interests, represented by conflicting political groups. On one hand, the government of the state of Pará, until 2006 chiefly representing the middle and upper classes, aims at international tourism by supporting expensive tourist attractions. On the other hand, the Labour Party (Partido dos Trabalhadores), which governed the city of Belém between 1997 and 2004, tries to improve the Ver-o-Peso

more than seven hours barefooted on the hot asphalt. She is surrounded by thousands of children dressed in white as angels - these were saved from death during their first years of life. Other people carry wooden models such as houses, books or crutches on their heads as symbols to express their gratitude for help with difficult problems. Not only poor people from the Amazonian interior, but also young, well established ones walk in the procession, clenching the long, thick rope fastened to the carriage of the Madonna (Nossa Senhora de Nazaré).

17 Above all maniçoba, mainly consisting of maniok leaves and meat, which takes a whole week to be prepared properly, and pato no tucupí, duck cooked in the traditional manner.

18 See tourist information and various websites in the internet. 
as the central market of the native population and the adjacent lower middle class residential area.

There is a lot of reconstruction going on in the market Ver-o-Peso. A number of the old wooden roofed stalls standing very close to each other and forming a kind of dark, rather sinister-looking alleyways have been taken down and replaced by stalls made of bricks and spaced more widely. Tourist attractions and arts and crafts are offered. But the majority of the articles on sale - such as fruits, vegetables and fish, typical dishes from the interior, aromatic herbs and traditional medicine, charms and love potions - is directed at covering the daily local demand and meant for immediate consumption. As the Ver-o-Peso is thus chiefly used in the traditional way by the population, it is only marginally successful as a tourist attraction, particularly as both the market and the adjacent area do not meet the safety standards of tourists and the upper classes.

The fort and the adjoining area are open to tourism as a kind of outdoor museum. But in spite of efforts made by the local authorities, the majority of buildings are becoming increasingly derelict due to lack of funds. Yet many inhabitants are proud to live in this historical centre of Belém. They enjoy showing tourists the few, but very well renovated buildings around the fort and the Ver-o-Peso.

\section{Revitalisation of port facilities}

In the course of revitalisation activities in an abandoned area of Belém international port, three extensive old metal storage sheds plus an annex were converted into facilities for culture, recreation and tourism, and as such presented to the public under the name of Estação das Docas ${ }^{19}$ in May 2000. This project was given high priority.

For conception and planning, a typology was developed to present the city as a synonym for trade, enterprise and home town.

The image of the Estação das Docas as "home town" is represented by the waterfront, revitalised by using derelict warehouses and port facilities and explicitly including natural elements which point to the existing relation between city and water. Under the heading "window to the river", the focus lies on the river system as symbolic element of local culture. The government of the state of Pará also aims at presenting the new image of the city as attraction for urban marketing and investments into tourism. The general discourse is reflected in statements of the users

19 Station of the Docks. 
who, on one hand, continually stress characteristics such as splendour, pride, self-respect, modernisation etc. and, on the other, point to possibilities of providing additional employment (Amaral 2003: 24ff.).

With reference to the term "city of trade", the Estação das Docas clearly defines itself on the basis of the value of the facilities and their concept which is directed at the production of an object of luxury. At the time of competition for the project, costs were estimated at 6.2 million $\mathrm{R} \$$ (approx. 3 million dollars). In the end, after a number of alterations, work was completed at the cost of 24 million R\$, 19 million were contributed by the state and 5 million resulted from private initiatives. The change in the course of construction clearly aimed at extravagance. Initially conceived as "window to the river", the Estação das Docas gained a different connotation through additional accessories: walls made of special glass, air-conditioning (4 million $\mathrm{R} \$$ ), escalator and lift (500,000 $\mathrm{R} \$)$, revolving stage and terminal for passenger ships (550,000 R\$), etc.

In the estimation of users of the Estação das Docas 51\% were of the opinion that the results were well worth the financial efforts, whereas $49 \%$ stated that priority should have been given to more urgent matters (Amaral 2003: 26).

The conception "city of enterprise", the joint operation of public and private means in relation to the Estação das Docas, can be demonstrated by: a) the distribution of the construction costs between state and private initiatives, b) the administration of the Estação das Docas by the organisation Pará 2000. According to Pinheiro (1990: 12), this constitutes a strategy of the government in order to divide the area of the Estação das Docas in accordance with their interests. The reception of this innovation policy (partnership between political institutions and private initiatives) by the users was predominantly positive. Only a relatively small number of interviewees pointed out that the enterprises engaged in the Estação das Docas do not encourage access and use by the general public (Amaral 2003: 27).

The first section contains a theatre with about 400 seats as well as an area of about $1,000 \mathrm{~m}^{2}$ for exhibitions and small fairs. In the second section various expensive restaurants and small shops are situated and in the third a restaurant owned by a brewery, a number of snack-bars and cafés as well as some shops selling mainly arts and crafts. The annex holds tourist agencies, banks and a terminal for sightseeing-boats. Tours of two to four hours are offered three times a day and more extensive tours on Sundays.

Old cranes painted yellow are integrated into the Estação das Docas, flanking the promenade along the quays. Walking towards the Ver-oPeso one reaches a small amphitheatre. On Sundays, the general public 
can watch performances of theatre or clown groups free of charge. Unfortunately, there are no trees or any other sort of shelter, so that the audiences are either scorched by the sun or soaked when it is raining.

In the meantime it is obvious that the Estação das Docas is practically exclusively reserved to higher income groups and tourists, as most of the population cannot afford the prices charged. The area is conspicuously clean and tidy and watchmen ensure that the users are wellbehaved. The recreation possibilities are more or less selective. Yet many people belonging to lower income groups, even some of those living in baixadas, demonstrate a certain pride in the achievement and the beauty of the Estação das Docas, although they are generally excluded from using it themselves. Quite a few pointed out that some cultural events are open to the general public and that the Estação das Docas are among the places where they would take strangers to the city when they wanted to show them around.

\section{Conclusion}

The "Gate of Amazonia" as crossroads: The focus is Belém, situated where city and inland meet and overlap. Port and river function as centres of trade, transport, information and communication, taking up the vital interests of the people. The movements around the port area directly or indirectly reflect the processes of development and change and their effects on the city and on the different groups of its population.

Initially the direction of movement was inwards along the river systems towards the rain forest. There followed a long period when interest almost exclusively concentrated on exploiting the riches of the Amazonian interior and exporting them abroad. This was the time when the sea port gained more and more importance as it grew with the increasing demand, particularly during the rubber boom. With the shifting of outside interests, it gradually lost significance. The river traffic was also intensified during the rubber boom. With its decline this also lost some of its importance but increased again when rural exodus started in the middle of the $20^{\text {th }}$ century.

The townscape of Belém mirrors the stages in the development of international and river ports and the accompanying economic and social processes: from the first urban area restricted by the river Pirí, to the zone of commerce and residential quarters for higher income groups which had emerged with the intensification of international trade on one hand and the settlement of migrants from the interior in areas which are 
regularly flooded along the river Guamá and along several small rivers (igarapés) in the city itself on the other.

Revitalising activities in the port and river area aim in two directions. There are some efforts by the local authorities to improve conditions in the historical centre and the adjacent middle class residential area to keep the population from moving away. Another factor is the now possible access to the riverside and its use by the general public. The main interest, however, is the creation of a new image of the city to stimulate tourism and urban marketing. These activities are partly supported by private initiatives, as exemplified by the construction and use of the Estação das Docas. Although the lower income groups are mainly excluded from the benefits of such revitalising measurements, many of them take pride in the new achievements.

In spite of these various efforts, the outcome is still a society divided socially and separated geographically in the different districts of the port area.

\section{References}

Amaral, Márcio Douglas Brito (2003): “'Waterfront' como imagem urbano: produção do espaço para fins de cultura e lazer na orla fluvial de Belém". In: Simpósio Amazônia, Cidades e Geopolíticas das Águas. Anais do Simpósio, 25-27/06/03, Belém: NAEA/UPFA, pp. 24-27.

Benchimol, Samuel (1988): Os Judeus na Amazônia, Manaus: Editora Valer.

Campos, Luís Arnaldo (1997): "Belém. Aqui começa a Amazônia", Nosso Pará 4, pp. 105-107.

Cañete, Voyner Ravena/Ravena, Nírvia/Rodrigues, Alice da Silva/ Longo, Filomena Viana Mata (2003): Pesquisa: Oferta e Demanda Habitacional no Centro Histórico de Belém, Belém-Pará: Universidade da Amazônia.

Cardoso, Ana Cláudia (2003): “O espaço construído das baixadas e as perspectivas de vida dos seus habitants”. In: Simpósio Amazônia, Cidades e Geopolíticas das Águas. Anais do Simpósio, 25-27/06/03, Belém: NAEA/UPFA, pp. 37-40.

Cruz, Ernesto (1958): Colonização no Pará, Belém: Conselho Nacional de Pesquisas.

Enciclopédia Ilustrada Folha (1996), Folha de São Paulo.

IBGE - Fundação Instituto Brasileiro de Geografia e Estatística: Censo 2000. 
Kohlhepp, Gerd (1986): Amazonien. Regionalentwicklung im Spannungsfeld ökonomischer Interessen sowie sozialer und ökologischer Notwendigkeiten, Cologne: Aulis Verlag Deubner.

Lopes, Adaise/Coelho, Ivaneide (2003): "Reorientando Olhares sob o Estuário: a importância portuária das cidades estuarinas na Amazônia”. In: Simpósio Amazônia, Cidades e Geopolíticas das Águas. Anais do Simpósio, 25-27/06/03, Belém: NAEA/UPFA, pp. 63-67.

Marin, Rosa E. Acevedo (2003): "Portos e trapiches de Belém". In: Simpósio Amazônia, Cidades e Geopolíticas das Àguas. Anais do Simpósio, 25-27/06/03, Belém: NAEA/UPFS, pp. 78-79.

Matos, Alcis (2003): "Esse rio é minha". In: Simpósio Amazônia, Cidades e Geopolíticas das Águas. Anais do Simpósio, 25-27/06/03, Belém: NAEA/UPFA, pp. 109-112.

Ministério da Agricultura, Indústria e Comércio (no year): Imigração e colonização. História e Estatística, Estado do Grão Pará, 1616-1916.

Oesselmann, Rosemarie (2000): Wege der Veränderung. Migrantinnen in Ost-Amazonien, Mettingen: Brasilienkunde-Verlag.

Oesselmann, D./Ferreira, F./Garcia M.L.G. (2006): Encontros Transculturais: a construção da identidade de jovens na Amazônia Oriental Brasileira, Belém: UNAMA.

Oesselmann, Rosemarie/Oesselmann, Dirk (2006): „Überlebensstrategien außerhalb staatlicher Systeme - Beispiel Brasilien“, Ethnoscripts 8 (1), pp. 93-101.

Penteado, Antônio Rocha (1973): O sistema portuário de Belém. Coleção Amazônica. Serie José Verissimo, Belem: Universidade Federal do Pará.

Pinhero, Vanessa do Rosário Castanho (1996): O processo de privatização dos portos em geral e em particular o porto de Belém sob a doutrina neoliberal, Belém-Pará: Universidade da Amazônia.

Ravena, Nírvia/Cañete, Voyner Ravena/Vianna, Filomena Mata/Rodrigues, Alice da Silva (2003): "Centro Histórico de Belém: entre o rio e a cidade". In: Simpósio Amazônia, Cidades e Geopolíticas das Águas. Anais do Simpósio, 25-27/06/03, Belém: NAEA/UPFA, pp. 51-54.

Wagner, Dyrce Koury (1996): Articles in Nosso Pará No. 2, pp. 6-21. Zaidan, Assaad (2001): Raizes Lebanesas no Pará, Belém. 


\section{Contesting Nodes of Migration and Trade in Public Space: Thessaloniki's Bazaar Economy}

\section{SALINIA STROUX}

Based on ethnographic fieldwork in Thessaloniki (2003 and 2004), this article concentrates on the bazaars of urban irregular ${ }^{1}$ refugee $^{2}$ street vendors ${ }^{3}$, and on the port city as a node of migration and trade. ${ }^{4}$ I will argue that street vending compensates for the loss of day labour jobs in

1 In the following I will use "informal" and "irregular" as open categories as proposed by Greiner (2003: 51) referring to forms of work and of gaining livelihoods or survival, which are not, or only rarely registered by official statistics of the regulated economy (Komlosy et al. 1997: 10). When I refer to the street vendors as "working informally", I mean that they have no licenses and cannot get them because of legal requirements, and therefore pay neither taxes nor self-employed insurance contributions, with all the respective consequences.

2 In this context, "refugees" are defined with Jacobsen as "all people crossing the border from conflict-affected countries, regardless of their assigned legal status in the host country" (Jacobsen 2005: 5). I will use the term "refugee" both for recognised refugees and for asylum seekers. Whenever a distinction is necessary, I will use the terms "asylum seeker" and "recognised refugee" explicitly.

3 I will use the terms "street vendors", "street traders" and "street hawkers" interchangeably and consider the self-employed hawkers described in this work as "entrepreneurs", i. e. people who own and run their own business (Kloosterman/Rath 2003: 14).

4 Main methods used in the field included participant observation, semistructured interviews with street vendors and other members of refugee communities, social workers, formal trade representatives, local politicians such as the vice mayor and municipal police officers, as well as the analysis of scientific literature, local and national newspapers and internet pages. 
the port economy. Rationalisation of work in the port has influenced the urban economy and indirectly enforced the increase of (informal) street trade. Furthermore, waterfront revitalisation, as well as ensuing urban transformations aiming to increase Thessaloniki's competitiveness, are shaped by an ideal image of a modern European port city that leaves no space for irregular hawkers. Nevertheless, the street bazaars, more than anything else, represent the nodal function of port cities on a micro level. Different actors produce and use specific images of the city both consciously and unconsciously, and the streets as bazaars become a site of contestation.

While the world of street markets in Greece is colourful and diverse, this article will focus on asylum seekers and refugees, trading in the informal sector. ${ }^{5}$ This is one exemplary group of low income (temporary) refugee entrepreneurs who have formed survivalist or "displaced ${ }^{6}$ livelihood networks" (Jacobsen 2005: 1).

The port city of Thessaloniki has a long tradition as a node of migration and trade. It is situated at the crossroads between Europe and Asia, connecting the European Union with the former Eastern Block and the Orient. Due to its geopolitical position, the city has always played a major role in migration and trade.

In the past two decades, Thessaloniki has been strongly promoted as a multicultural city with a colourful history. Historic sites from Byzantine, Roman or Ottoman times have become tools of publicity campaigns, attracting both tourists and investors. Besides the monuments of the past, it is also the actual presence of immigrants from diverse countries such as Albania, Bulgaria, Nigeria, the former Soviet Union, China, Pakistan, Turkey, Iraq, as well as the former Asia Minor refugees, which contribute to the multicultural image of the city. These different groups have been shaping the physical and social space of Thessaloniki by meeting in public squares, playing cards or chess in the parks. Restaurants, supermarkets and bookstores offer "ethnic" products to migrants and local clients, and the urban soundscape carries fragments of Albanian, Russian, Bulgarian and many other languages.

5 A high percentage of political refugees and especially asylum seekers in Greece live in a state of transit characterised by a high level of vulnerability, insecurity, instability and socio-economic marginalisation within the Greek society. The transitory nature of refugees' lives is attributable to the fact that most of them are asylum seekers and remain in the asylum process with an unforeseeable outcome. The respective legal status holds many difficulties for the refugees and turns the provision of their basic needs into a question of survival.

6 The term "displaced" refers to the status of the individuals as forced migrants or refugees. 
At the same time, local authorities and urban developers aim at turning Thessaloniki into a modern and neo-liberal European port city, while insisting and underlining its regional role as "Capital of the Balkans". Thessaloniki has become a role model as the first Greek city focusing on waterfront development (Gospodini 2001: 286). The planed improvement of infrastructure also implies control and limitations of (informal) trade to a tolerated minimum, if not eradicating it entirely.

In the market, divergent interests collide. Different uses, perceptions and daily practices contribute to the construction and contestation of public space. Thus, the streets and other public spaces where street vendors survive are often sites of competing interests of traders, city authorities, business investors, municipal police and the general public. ${ }^{7}$ Finally, the microcosms of the street markets contribute to the image of the multicultural port city, while, on the other hand, they represent "unwanted" and "illegal" elements which are viewed as contradictory to the ideals of a "European" Thessaloniki.

In this article, I will show two conflicting versions of port-city image construction. Local policy and public discourse have shaped the image of Thessaloniki as a multicultural European port city as a successful strategy of city development manifested in public space. On the other side, by becoming part of the bazaar economy irregular migrant street vendors implicitly produce, and make use of, this image of multicultural Thessaloniki in a pragmatic way. While the planners' ideals result in redevelopment plans and intensified control of public space, the immigrants' activities are not just part of their "cultural luggage", but a result of limited professional choices in the context of global, national and local transformation processes and international migration.

\section{Port cities as nodes of migration and trade}

Port cities are nodal points in the complex system of international labour and trade (Läpple 1994: 462; Schubert 2001: 16) and are highly competitive to each other. More than $90 \%$ of the global trade volume occurs by sea (Rodrigue et al. 2006). Consequently, port cities serve as maritime gateways for the centres in the hinterland. But they have also always been nodes of migration. The bazaar economies of port cities link and localise both dimensions of movement: of goods and of people.

7 The study has been part of the EU project "European Port Cities: Disadvantaged Areas in Transition", which focused on the subject of social exclusion. 
International competition between cities in their global network has a direct impact on urban transformations and competing image ideals in Thessaloniki. Municipal and national governments and urban planners invest in improved infrastructure and place marketing, in order to increase the city's attraction and success as a European, or at least Balkan, hub of trade, industry and tourism. Waterfront redevelopment is one major aspect on the agenda of the competitive city, and has been a hallmark of urban revitalisation strategies since the 1980s (for Greece see Gospodini 2001; see also Hoyle et al. 1988; Gordon 1997; Malone 1997; Marshall 2001). In consequence, urban transformations and image changes have led to the exclusion of "unwanted" and "illegal" users of public space like informal street vendors. ${ }^{8}$

"The redevelopment of urban waterfronts into gentrified residential and commercial areas produces new spaces for investment and accumulation and provides symbolic visuals for entrepreneurial 'city branding' campaigns." (Cowan/Bunce 2006: 429)

Urban public space is shaped by these policies and ideals, but also by the activities of local actors and by the reactions of urban authorities. It is socially and culturally constructed and constantly being (re-)negotiated by different social, ethnic or gender groups. Public space materialises in physical place, shaping social interactions and feeding imaginary and discursive representations (Harvey 1993; Lefèbvre 1994; Brown 2006: 22).

Immigrant street vendors influence the city's public space by their activities as much as the rest of the population, but with one difference: their activities are visibly concentrated in the city centre, thus playing a prominent role in the process of image construction. ${ }^{9}$ Equally present are the strategies of police forces, tax officers and border patrols to counteract and prohibit informal trade. Pedestrians form a third party in the contestation of public space. While many of them are customers, some are also opposing the hawkers.

8 Informal trade is often seen as hindering the efficient operation of cities and it is said that it prevents progress (Rogerson 1989; Centeno/Portes 2003), a position supporting prohibitive interventions, which seek to exclude and remove traders (Lyons/Snoxell 2005: 1302).

9 Cross (1998: 44) compared the spatial behaviour of street vendors to the one of land invaders since they also aim to gain access to a public or privately controlled good through informal means. "Land invaders take over land that has not been authorized for sale or subdivision. Likewise, street vendors invade streets to use them for trade and frequently also to avoid taxes and regulations that push up costs for formal business" (ibid). 
The centre of Thessaloniki, being also the business centre of the city, has different meanings for these diverse actors and their everyday lives. The immigrant street vendors are interested in public space for reasons of economic survival, striving for access to space on the business streets, next to the bus station or at the central square, and frequently opposing the interests of formal traders and urban authorities. Thus, in urban public space both social norms and political practice manifest themselves, i.e. it has an "indirect role in supporting the economic and social aspirations of dominant business élites. Urban managers seeking to project the image of a modern city in order to attract foreign investment, or to upgrade the highway network, may undertake radical redevelopment or city 'beautification' that involves spatial cleansing with little regard for the existing users of space such as informal traders [...]" (Brown 2006: 24; see also Middleton 2003). As a result, urban public space can become a site of contestation (compare the cases of New York and Quito: Stoller 2002; Middleton 2003) since street vendors most often concentrate on places with high pedestrian flows such as transport terminals, shopping malls, streets and offices.

"Contest can arise from a number of sources, for example the protectionist approach of vested interests such as landowners and formal businesses, the desire of urban managers for orderliness and control, or the expression of political power and control. [...] The exclusion of 'undesirable activities' is an integral part of modern city management.” (Brown 2006: 12)

As Harvey $(1973,1993)$ has argued, urban public space is an imperfect common property resource because it is freely, but not equally, available to all individuals and even where access is permitted, use may be denied.

Transformations of maritime technology since the 1960s include containerisation, new port technologies, changes in size and nature of ships, new transport systems and the development of new port industries. Thessaloniki, like other port cites, has been facing significant changes in port structures and port-related labour, resulting in the rationalisation of work and the decrease of former port functions. In consequence, many port workers, dockers and day labourers, lost their jobs. A further significant change in the ports' role and growth occurred in the 1990es, when Thessaloniki regained access to its hinterland in the Balkans. In the past decades a process of revitalisation has been occurring in the port area. ${ }^{10}$ Port functions expanded and moved westward, while

10 "Revitalisation" refers to changing uses of space, renewal and reconfiguration due to different interest groups in the spatial interface of port and city (Schubert 2001: 16). 
the inner city port opened its doors to the public in 1997 in the course of the Cultural Capital events. Meanwhile, these areas which had lost their direct economic relation to the port have become centres of entertainment (compare Schubert 2001; Hoyle et al. 1988). It was the first experience of waterfront development in Greece (Gospodini 2001).

Nonetheless, the port is no more the central dynamic engine and economic base of the city (Läpple 1994: 466). Processes of revitalisation are supposed to fill this gap and to compensate through modernisation of the urban economy. As the case of Göteborg shows however, the new "waterfront-jobs" are not directed towards the same clientele of job seekers (Ekman 1998: 87). In the case of Thessaloniki, other forms of economic survival and day labour outside of the port were created by the job seekers themselves, drawing from local and national traditions.

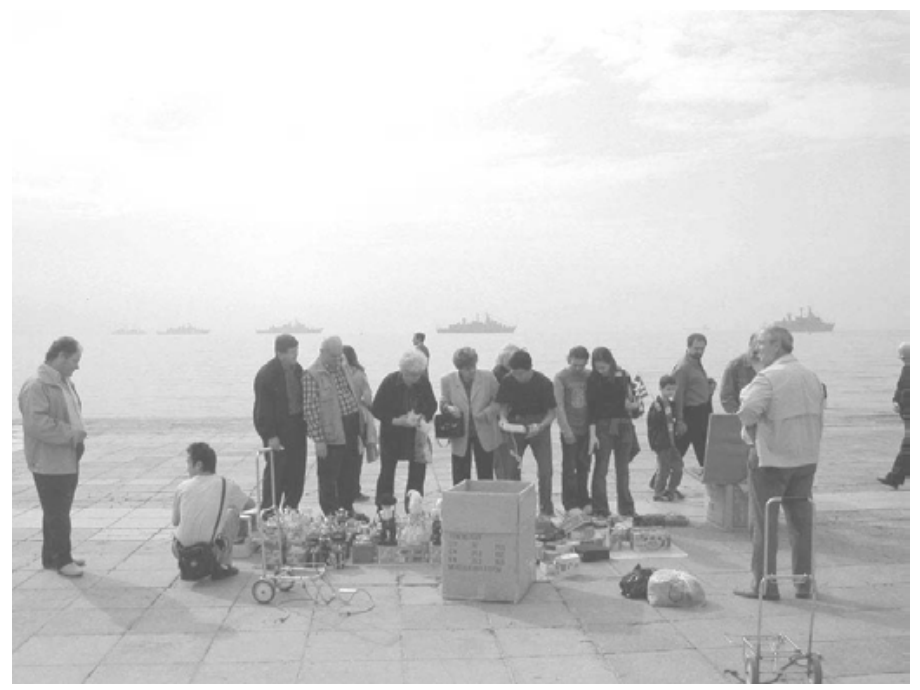

Fig. 1: Street vendor on the seaside of Thessaloniki (photo: Salinia Stroux)

Street vending is one possible economic strategy of informal selfemployment in the service sector. The informal economy is a process of income generation, which "is unregulated by the institutions of society, in a legal and social environment in which similar activities are regulated" (Castells et al. 1989: 12). It has to be distinguished from illegal economy, although boundaries are often blurred. The absence of state regulation in the informal economy may affect various elements of the work process, such as the status of labour (i.e. working undeclared, lack 
of insurance or social benefits, paid under minimum wage), the conditions of work (i.e. public hygiene, safety hazards), the form of management of some firms (i.e. systematic fiscal fraud) (ibid 13). Nevertheless, it can also be perceived as a construction bound to state regulation and different definitions in law.

Street vending is a typical subsistence niche of migrants in southern Europe's informal economies (Baldwin-Edwards; Arango 1999). Entrepreneurship provides work and income for groups who face substantial obstacles in the labour market, leading either to high rates of unemployment or to exploitative low wage employment (Kloosterman/Rath 2003: 3). "Ethnic entrepreneurship [...] [in southern Europe] [...] seems more to be a subsistence level occupation for the vast majority of immigrants engaged in it" (Baldwin-Edwards 1999: 9). It is certainly an alternative to earlier forms of day labour like the ones provided by port economies in the past, which have disappeared due to recent transformations in the port sector.

Following a definition by McGee and Yeung (1977), street vendors are "[...] those people who offer goods or services for sale from public spaces, primarily streets or pavements" (ibid 25). Apart from the spatial feature differentiating street vending from institutionalised markets or shops, Greiner (2003) adds the aspect of mobility, as the vendors move towards their clientele (ibid 5). Hence, in this article informal street vending is defined as an economic strategy of marginalised groups evolving out of structural pressure, social networks of shared experiences and individual choice, whereby street vendors use mobility to access their clientele on public spaces where they sell their goods. Irregular street vendors in particular are excluded from legal and administrative protection covering commercial licensing, labour contracts, income taxation and social systems (Reyneri 2001: 3). Based on research by Williams and Baláž (2005) on immigrant street traders in Slovakia, I consider refugee street vendors in Thessaloniki as actors "participating in multiple networks at different scales, which are both workplace and socially situated" (ibid 534). Their entry into the economy of street hawking is not just a response to their situation as refugees in a host country. They are reflexive agents responding to opportunities, and utilising various resources by networking on local, national and transnational levels, the main resource being their social networks. Hence, these refugees create new opportunities through their activities. 


\section{Urban change in Thessaloniki}

Thessaloniki was founded in $315 \mathrm{BC}$ at the north-western shore of the Thermaicos Gulf. With approximately one million inhabitants it is the second largest city in Greece, metropolis of northern Greece and capital of the Greek province of Macedonia, as well as a significant international port and commercial centre. It is Greece's second major industrial centre with a growing service sector, and accounts for $7.2 \%$ of all immigrants in Greece (Cavounidis 2002). Offering refuge for the Sephardic Jews from the Iberian Peninsula at the end of the $15^{\text {th }}$ century and being a general attraction point for other refugees, migrants, trade-diasporas and travellers, Thessaloniki has a distinct multicultural history. Due to the influx of refugees from Asia Minor in the 1920s, it was labelled "capital of refugees". Since its nomination as European Cultural Capital in 1997 , the multicultural history of the city has been promoted increasingly, pointing to the long tradition of coexistence of different cultures. New tourist sightseeing walks use this history as a focus of public image construction and promote Thessaloniki as a "European" city.

In consequence, during the past two decades Thessaloniki has been undergoing significant changes with the goal to improve the image of the city on political (EU membership), cultural (Cultural Capital 1997) and economic (e.g. tourism, EXPO) levels. In preparation for the 1997 Cultural Capital events, Thessaloniki was the site of various projects like the preservation of the upper city, the utilisation of modern period architectural heritage, the "freeing" of the city's monuments and distinct projects in the regional municipalities. The physical changes focused on the multicultural city image and on the upgrade of the historic centre ${ }^{11}$ (Tsoulouvis 1998). In 2003, further plans foresaw a 4,4 million Euro investment by the local government in different spatial projects - including the Ladadika area (Zouka 2003). These strategies of urban transformation resulted in the displacement of actors that had used the public space before, including street vendors, addicts and the homeless. Furthermore, public places and streets in the historic centre of the city have become representative symbols of Thessaloniki's leading role as a European hub in the Balkans. In consequence, special units of the border police control shopping malls and central tourist places like Navarinou Square. By patrolling and checking the papers of suspects, they create an image of security to some, and new forms of exclusion for others. At the

11 I.e. by the Urban Pilot Project funded from 1989 till 1993 and prepared by the Organisation of Thessaloniki for the Master Plan Implementation and Environmental Protection, which was set up in 1985 by the Greek ministry of environment. 
same time the police and private security personnel control street vending by patrolling the streets and squares and asking for work permits.

In 1953, the Thessaloniki Port Fund and the Board of the Free Trade Zone merged to one new body named Free Zone and the Port of Thessaloniki. The port extended and started to move westwards. During the 1960s the city underwent a construction boom and new industries moved into the region. As a result, the port specialised in the transportation of raw materials and industrial goods. In 1999 the Thessaloniki Port Authority became a private-sector company with listings on the Athens Stock Exchange. Following the redefinition and opening of European borders in the 1990s, the port of Thessaloniki regained its hinterland in the Balkans and former Eastern Block, and former transit routes were revitalised, supporting claims by the Thessaloniki Port Authority that "in the Balkans all corridors lead to the Port of Thessaloniki" (Thessaloniki Port Authority 2002). Today Thessaloniki is Greece's second major transit port handling nearly half of the Greek exports. Since 2001, the port of Thessaloniki, although being one of the smaller international ports, has become a hub for the EU connection to the Balkans and the Black Sea.

While the port has been growing and moving westward, it also changed functionally with a decreasing role as employer. One group affected directly by the port transformations are the specialised workers like dockers, transportation workers (coach drivers) or salvage and towage sailors. The personnel of the Port Authority declined successively. In some port professions, specialised employees have entered the job market. Other traditional port-related crafts such as porters or coach drivers, who still managed the transportation of goods until 20 years ago, have disappeared completely.

Today, the old port facilities in the historical centre of Thessaloniki have become a promenade filled with coffee bars. The former inner city port and its seaside scenery now serve as a background for street vending, tourist-tours by coaches, kiosks, musicians and visual artists. The revitalisation measures of 1997 and following years concentrated on a single-dimensioned re-use of space, creating spaces of "high culture" like exhibition halls, congress halls and expensive coffee bars, inherently excluding other groups of users and thus preventing the port from getting integrated into to the centre of the city. This led to alienation between the port and the inhabitants of Thessaloniki. Only the first pier which opened its gates in 1997 to the public is attracting a larger clientele for leisure activities. 


\section{A node of migration: Refugees' economic strategies}

Situated at the south-eastern borders of the European Union, Greece, especially the eastern part of the country, has become a point of entry for immigrants to the EU via Turkey. They usually come to Thessaloniki after arriving by boats at the eastern Greek Islands, or after passing through the north-eastern land borders. It is mainly these external EUborders that define Thessaloniki's role as a centre of human mobility. The proximity to Turkey, but also to Macedonia and Albania not only attract immigrants to the city as a place of transit. Since the 1990s, they have been entering Thessaloniki in growing numbers with the purpose of settling. This development is strongly influenced by European policies. The Schengen Treaty in particular had a great impact on the situation of immigrants in Greece, giving rise to the development of external and internal buffer zones, where immigrants can be prevented from entering the EU in the first place, or at least are forced to remain in their first safe host country within the EU - which in this case is Greece.

Southern European countries such as Italy, Spain, Portugal and Greece were traditionally countries of emigration until the late 1980s. Sizeable inflows of permanent migrants have only recently begun (Reyneri 2001: 11). Numerous unauthorised migrants from Eastern Europe, Iran, Iraq, Afghanistan, Nigeria, Pakistan and other countries have been arriving in Greece over the last three decades. ${ }^{12}$ As southern Europe's state with the highest proportion of foreigners (Reyneri 2001: 11), Greece still struggles to recognise this fact officially, and to react appropriately to the realities of being a country of immigration (Reyneri 2001: 11ff; OECD 2005: 117). According to estimates quoted by Reyneri (2001: 5f), unauthorised migrants ${ }^{13}$ in Greece $(1.7 \%$ of local population) already outnumbered the authorised migrants in 1992 (1.3\% of local population), while in 1998, this number reached an even higher percentage (5\% vs. $0.9 \%$, Reyneri 2001: 6). Two regulation procedures have already been completed (1998 and 2001) and a third one ${ }^{14}$ is in the process of being passed. Refugees whose asylum cases were rejected be-

12 Until recently, immigration laws did only rarely allow for legal immigration so official numbers of foreign-born people remained largely unrecorded, since most migrants were entering the country unauthorised.

13 Greek nationals and other EU members excluded.

14 This third regulation has introduced a new set of financial prerequisites, including a fee of 1,500 euro for an application to enter the process of legalisation. 
fore the end of 2004 are now allowed to apply for a migrants' residence permit (green card), thus changing their status.

The massive influx of migrants to Greece is probably due to its geostrategic location, with many kilometres of external European Union borders and the proximity of transit to source countries. As most refugees, after arriving in Greece, hope to move on to other European countries with better asylum and reception conditions and higher recognition rates (Papadopoulou 2003: 348), they either try to remain undocumented or they apply for asylum without the intention of permanently settling in Greece. The decision to stay depends mainly on local opportunities to integrate successfully, and on the degree of embeddedness in transnational migrant networks.

The Greek job market and its accessibility constitute significant difficulties for refugees, because Greek refugee policy does not offer any public welfare support. As a result refugees urgently need to find jobs. Greece, in contrast to other European member states, provides asylum seekers with a work permit to "cover their basic needs" (since 1998), although it is restricted to salaried employment and does not include the right to self-employment (Mestheneos 2002: 184; Skordas/Sitaropopulos 2004: 46). ${ }^{15}$ Other than that, there is no policy of economic integration for refugees except for a de-facto integration in the shadow economy, where most refugees are (self-)employed (ibid 47). ${ }^{16}$ The UNHCR has underlined in its reports that "a large number of refugees (in Greece) live beneath the poverty line" (UNHCR 2002).

Regarding the limited possibilities within the regular labour market, self-employment, though irregular, has become an attractive alternative. It is a temporary solution and economic integration strategy (Papadopoulou 2003: 353) which, interestingly enough, follows the same patterns as natives' strategies. High unemployment rates $\left(3^{\text {rd }}\right.$ quarter 2005 $9.7 \%$ for Greece and $11.4 \%$ for the Thessaloniki agglomeration) may explain the very high rate of self-employment among Greeks (National Statistic Service Greece 2005). "It is both a cultural preference and a way out of unemployment or underemployment" (Mestheneos 2002: 187).

15 Refugees receive a work permit under the precondition that they first apply for asylum and receive residence permit. Once they have passed health tests they can apply for a work permit at the prefecture. With the work permit they can get a tax number (AFM) and go to the job office to receive an unemployment card. After receiving a work permit (2-7 months after arrival) the situation changes and opportunities begin to arise.

16 Transient policy describes a state of 'non-policy' that is typical of local authorities in the first phase of labour migration, when the immigrant population is still small and many of them are undocumented. 
Arriving in Greece, asylum seekers encounter an economy with specific socio-economic characteristics: a large informal economy; a high rate of self-employment and the subsequent fragmentation of the economy into small, mainly family-run enterprises; seasonality and high labour intensity in construction or agriculture; and a rejection of low-paid, low-status jobs by Greek citizens due to higher education levels, higher socio-economic aspirations and the delayed labour market entry of the young and women. There is a big demand for unskilled low-wage labourers, attracting and binding immigrants to Greece (Fakiolas 2002: 60ff; Hatziprokopiou 2004: 327f; Mestheneos 2000: 5ff; Reyneri 2001: 58).

Nonetheless, newcomers usually have few employment options before they are able to get a work permit (Fakiolas 1999: 215). For this first phase without a work permit, the majority of refugees and social workers perceive street vending as the best choice. My fieldwork suggests that in time, migrants' social networks function as informal employment agencies. Besides friends and expert institutions like specialised social workers or the local job office, they also consult newspapers or use the "Piazza", open markets for day labourers. The longer people live in Greece and the more experiences, contacts and knowledge they have, the higher their expectations, their chances and the likelihood that they end up finding better jobs.

Concerning refugees' participation in informal street vending, social workers and NGOs working with refugees criticise the limited possibilities for immigrants to engage in regular street vending. They see this profession as the best alternative for many asylum seekers, despite its illegal status. In their daily work they are confronting the refugees' problems concerning permits, confiscated goods, fines and criminal proceedings. A social worker from a local refugee organisation stated in an interview:

\footnotetext{
"Street vending is a solution for those asylum seekers who cannot work in hard, dangerous and difficult jobs in factories, in construction or crafts, who cannot work in the legal sector, because they have problems of health, they are handicapped, victims of torture, have for some reason no work permit or they might have a formal job which is not sufficiently paid. They have no other choice to generate livelihoods but to do this informal work. [...] Street vending as a profession in their countries of origin is not being perceived as something to be proud of, therefore I assume that most of them are forced to work in this niche for reasons of survival." (Interview with S.K., 30/04/2004)
} 


\section{A node of trade: The streets as bazaar}

Thessaloniki's role as a magnet for tourism is of particular importance in the interrelation of image construction, local policy and the transformation of urban space. Thessaloniki's selection as European cultural capital in 1997, the choice of the city as a venue for the Olympic games 2004, and attempts to draw EXPO 2008 to the city, motivated plans for an appropriate representation of the city as both "multicultural" and "European". One example is the planned renewal of the central public market. Since the opening of the Balkans, Thessaloniki and surrounding areas have also become a first choice for big new shopping malls and international companies even before Athens, because there is a steady influx of tourists from the Balkans, coming explicitly for shopping.

Thessaloniki's nodal functions become most visible in public space. A growing number of Chinese products enter the Greek market, ethnic enterprises open around the central square, international money transfer and telecommunication offices promote global contacts, and street vendors from different national backgrounds sell goods from various countries on the streets and in the markets.

Ambulant and stationary street professions have a long history in Greece. Informal street vending is an established alternative profession and has always been a strategy of the economically disadvantaged. This does not mean that it is generally tolerated, supported or recognised by the public or the state, but it has survived until today, despite attempts to reduce informal trading to a minimum. A century ago street vendors, selling koulouria (Greek sesame pretzels), salepi (traditional drink imported by Asia Minor refugees), flowers, milk, newspapers, pottery and many other things, belonged to the daily picture of urban Greece. ${ }^{17}$ There were also many other itinerant labourers present in the city, such as mobile trades- and craftsmen who provided their services in public space. These street professionals either used the street directly as their workspace, or indirectly as a contact point with potential customers. Some of these professions were predominantly associated with specific ethnic groups, but they all represented economic strategies of the "urban poor" (Tsaktsira 1997: 207f).

As a result of industrialisation many of the old professions disappeared, but a neo-liberal and global economy has raised new necessities,

17 Many of the street foods had first appeared in the Constantinople and Smyrna of the $17^{\text {th }}$ and $18^{\text {th }}$ century and were introduced to the Greek capitals from the mid 1800s till the arrival of Asia Minor refugees in Greece. For a more detailed history of Greek street foods and their origin see Matalas and Yannakoulia (2000). 
and opened new opportunities for flexible small-scale enterprises. Street vending has remained an attractive economic alternative until today, although it has changed its face and has been adjusted to the current market conditions. There are no reliable figures available, but the police estimate that vendors in Greece (regular and irregular) number around 10,000 with an upward trend (Athens News 2003).

Street vending is still a profession of the economically disadvantaged (Matalas/Yannakoulia 2000: 15). Nevertheless, for some it has brought greater wealth and higher income opportunities than for others, who can barely survive. In 1995 the Greek government passed a new law which defines street vending as a social project exclusively for disadvantaged parts of the population (i.e. handicapped, heads of big families or war veterans), and limited to a number of "traditional goods"18 as koulouria, nuts, books, flowers and old furniture. ${ }^{19}$ Thus in its legal form, street vending is limited exclusively to small parts of the native population, and only few people enjoy the advantage of an official permit. The street vending licence is usually bound to one place, it has to be renewed annually and the vendors have to pay taxes and contribute to the insurance fund for self-employed.

Although non-Greek nationals are excluded from legal access to this profession $^{20}$, street vending in its irregular form has become a niche for immigrants with different legal status (Rosewarne/Groutsis 2003: 13). Apart from a few regular hawkers who mainly offer koulouria, nationallottery coupons or "traditional" goods, there are many different types of irregular street vendors in Thessaloniki. They may be Greeks - especially elderly, Greek Roma, or they come from other countries, particularly Egypt, Nigeria, Congo, Sudan, Afghanistan, Iran, Iraq, Albania and Georgia. These street vendors sell a variety of goods ranging from CDs, DVDs, sunglasses, cheap jewellery, and watches, toys, scarves, flowers, balloons, collectors items, nuts or sweets, tissues, idol cards, gloves, self-made articles like socks or carpets, or cosmetics, just to name a few. These diverse groups build social networks on different levels. They create co-operatives and compete with each other.

Street vendors differ in the way they work, in the products they sell and the markets they serve. Elderly women from Georgia and other

18 The classification of "traditional goods" is the responsibility of the local authorities.

19 Since 1970 street vending is under control of municipality and prefecture authorities, whereas licensing used to be the responsibility of the General Commissioner of Police before (Matalas/Yannakoulia 2000: 13).

20 Nevertheless, there are some exceptions to that rule. A few immigrants have obtained licenses for street vending in Athens (approx. 200 persons). 
countries of the former Soviet Union sell fresh spices and vegetables on a small scale, serving mainly ethnic markets. Anglophone Africans sell pirated CDs and DVDs, serving a non-ethnic clientele. They walk from one coffee bar to the next restaurant and offer their goods mainly to Greeks and tourists. Francophone African street vendors offer exotic products to a non-ethnic market, profiting from an underdeveloped market niche in Greece by selling "African” wood arts, jewellery and bags. Chinese mobile vendors use vendor's trays to hawk a diversity of cheap electronic stuff like massagers, singing dolls, or radios, walking from one restaurant to the other and selling to a variety of customers.

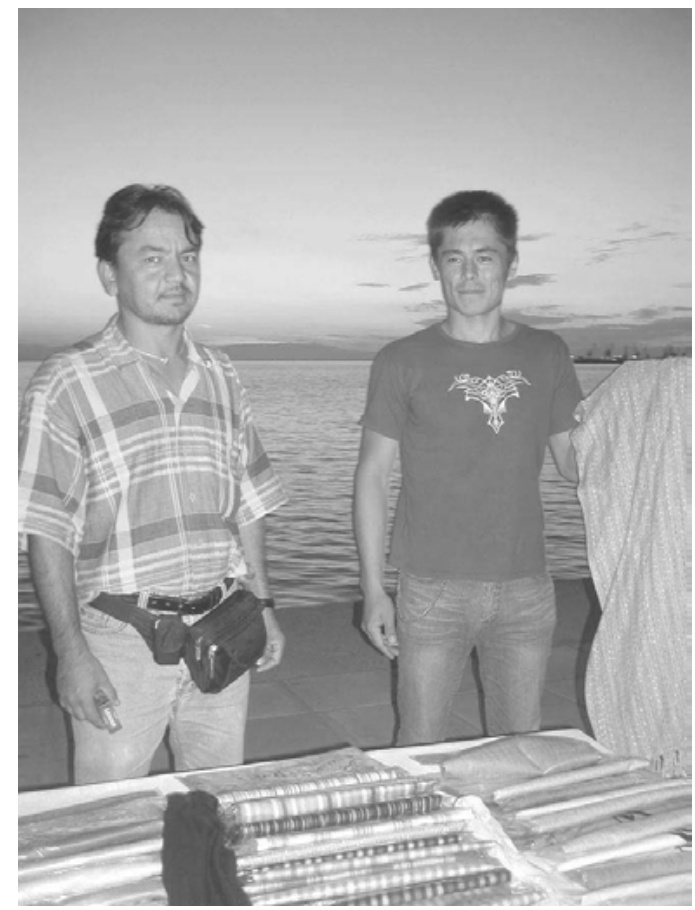

Fig. 2: Refugees selling Chinese scarves (photo: Salinia Stroux)

Refugees working as irregular vendors in the streets of Thessaloniki are part of what Baldwin-Edwards (1999: 1) has labelled a "twilight zone". Despite efforts to get a licence for street vending, they remain informal professionals for structural reasons. In my fieldwork, I have focused on a network composed of Afghan, Iranian and Iraqi refugees. In the most ambulant version, they sell scarves in winter, sunglasses in summer, Santa-Claus hats at Christmas time, watches and bracelets or other jew- 
ellery throughout the whole year. More stationary vendors also hawk bags, clothes and small electronic accessories at weekly markets.

These street vendors work in different places and create individual combinations of work spaces, but the majority sell in the main business and shopping area in the centre of the city, because of the high fluctuation of clientele, a low degree of danger, high degree of protection and low competition with established shops and other vendors. Generally speaking, the better the relations to neighbouring shops, the fewer problems with the police, the greater security, and the fewer similarities between the goods of shops and street vendors, the less competition and the fewer conflicts arise.

A central agglomeration of hawkers is situated in the commercial centre around Tsimski Street, Ag. Sofia Church, Aristotelous Square and Egnatia Street. A second seasonal site for street vending is the seaside promenade and the White Tower square, a highly frequented recreational area in summer time. Some vendors also look out for specific locations that are lucrative because of their uniqueness in centrality and low competition, where they can exercise their business as a monopole. Most suitable are junctions and other sites close to shopping areas, malls, big supermarkets, institutionalised markets and central business streets. Special events like the EXPO, concerts or religious festivals next to churches also attract hawkers. Other important locations connected to the street as workplace are the weekly markets in different areas of the city. Usually, irregular vendors open their stalls at the edges of the formal markets.

There are up to eight or nine markets in different quarters of the town every day. Additionally, two private Sunday markets (called "Joussouroum") in the outskirts offer a semi legal status. They are both officially run by two different Gypsy unions and offer everyone the possibility of renting a place and selling things with or without a general street vendors' permit. Nevertheless, they are highly contested institutions with an unforeseeable future, since the city is preparing to close them down and open a public Sunday-market according to legal regulations instead. Finally, in the summer when people leave the cities for vacations and flee the urban heat, the street vendors also move out as far as possible and profitable - depending on whether they own cars or whether they can join others with cars. They follow the tourists mainly to Chalkidiki, a tourist region in the south-east of Thessaloniki. 


\section{Contested images, contested space}

Public markets, and especially multicultural ones, usually attract tourists all over the world. Nevertheless, immigrant informal street vendors do not seem to fit into the agenda of waterfront revitalisation and development of the historical centre. Street vendors without licences form a highly visible and therefore vulnerable part of the informal sector. In public discourse, street vending is seen as a major obstacle to the national economy. The Chamber of Commerce complained about informal street vendors and the sub-standard goods from their Chinese suppliers as a "scourge of our epoch that kills off the future of trade" (Charisis 2004). Fears relate to illegal market competition to the small-scale trade sector, disturbances of tax-paying pedestrians, and a negative influence on the city's image. In the words of the vice-mayor of Thessaloniki: "We will not let our city be transformed into a great bazaar! Our city is not a welfare office for those residents who are unable to generate their livelihood.'(Interview with vice mayor, 29/04/2004)

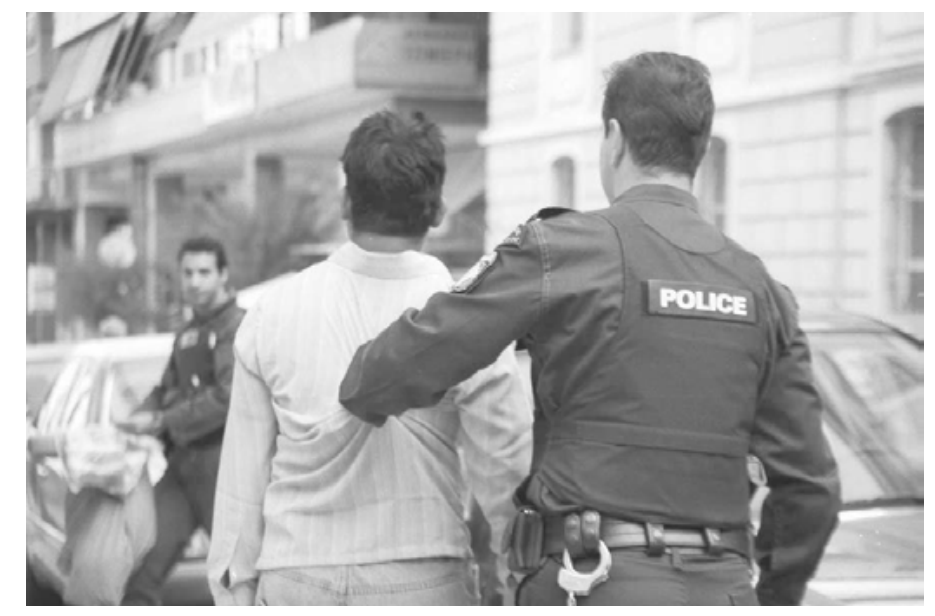

Fig. 3: Arrest of a street vendor and confiscation of his goods (photo: Ioanna Katsarou)

For these reasons among many others, street vendors confront massive state intervention reaching from daily police and tax officer controls to the confiscation of their goods, fines, arrests and even criminal proceedings. They are directly affected by consequences of gentrification and urban upgrading, such as expulsion from public space and frequent controls. More than ever, an intensification of conflict could be observed 
under the pressure of the Olympic Games 2004. Since then, controls have even been strengthened; and new laws and directives have been enforced.

On the other hand, street vending is simultaneously tolerated to a certain degree. One reason is the high demand for cheap products. Customers buying from the hawkers represent different segments of the population, i.e. Greeks, tourists or migrants. Another reason is a widespread sense of solidarity with vulnerable groups, observable in the daily contacts between hawkers and customers. On a face-to-face level, there are even forms of occasional co-operation between regular and irregular vendors. $^{21}$

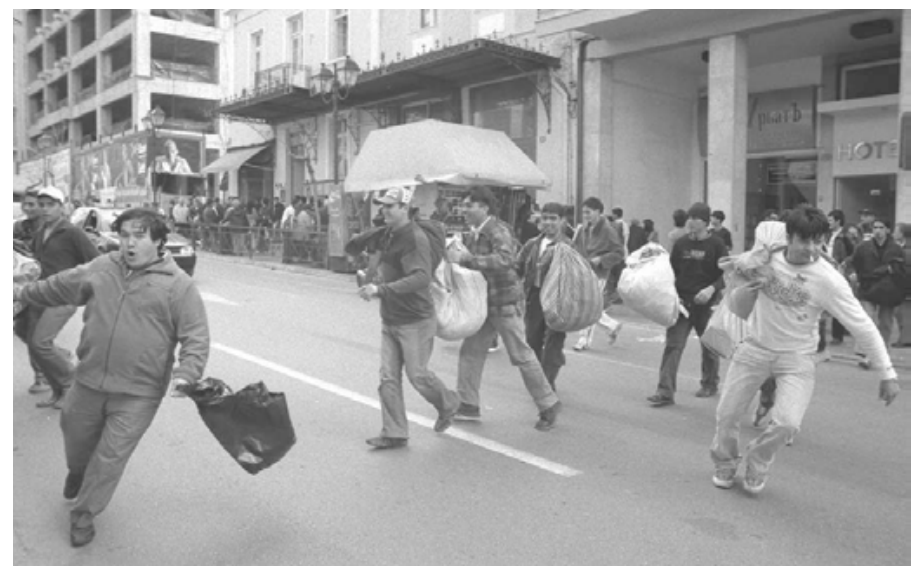

Fig. 4: Street vendors fleeing with their goods (photo: Christos Stefanou)

For the economically disadvantaged, street vending can be an economic (survival) niche even in its irregular form, although in Greece there is a trend towards an intensification of conflict. Despite increasing state interventions and public insult, the customers do not stop buying, nor do the street vendors turn their backs on their jobs. Thus it is a temporary economic solution and might even become a successful self-employment strategy, but it remains a highly precarious job opportunity with an unforeseeable future.

21 Bromley (2000) described these seemingly contradictory policies as typical and talks of "containment". 


\section{Conclusion}

Traditionally, ports have been places of economy and trade, as well as places of passage for different populations. This idea still lives on in our minds. If we think of ports, we see ships and we see markets, and a colourful mixture of people. Today, a big part of the ongoing trade in the port area is indeed invisible to the public. The street vendors reinforce the mental picture of port cities that is still alive in advertisements of the tourist industry and other image constructions. They fit quite well into the seaside panorama of the promenade and the picturesque port-city face of Thessaloniki. The vendors are attracted to the seaside because of its recreational function for inhabitants and tourists, who enjoy the port as background scenery. As itinerant traders traditionally connected to the port, they contribute visually to the port city's image while utilising the market value of the port scenery, in a balancing act at the boundaries between illegalisation and expulsion from public spaces.

Street vendors represent a variety of different backgrounds and different statuses from illegalisation to legal working permits. Besides the Greek elderly and "traditional" vendors, it is mostly the newcomers in town who enter the street vending business. Access is relatively easy, it is a flexible profession and no large investment of capital is needed in the beginning. Of course, the disadvantages are plenty. As a part of the Greek (shadow) economy and as a part of urban street-life, street vending is directly interwoven with current changes in public space, which again are connected to international port-city developments. As "multiculturalism" has become a resource in promoting the city to investors and to tourists, street vendors are part of the colourful picture used to construct a port-city image. The streets of Thessaloniki have remained a bazaar in a contested space which is constantly re-negotiated. It is here that the characteristics of the port city as a node of migration and trade become most obvious, and different uses and images of port cities are in conflict with each other.

\section{References}

Athens News (2003): Immigration and the Economy. Special Supplement to Athens News 19/09/2003 (www.athensnews.gr).

Baldwin-Edwards, Martin (1999): "Where Free Markets Reign: Aliens in the Twighlight Zone". In: Martin Baldwin-Edwards/Joaquin Arango (eds.), Immigrants and the Informal Economy in Southern Europe, London/Portland: Frank Cass Publishers, pp. 1-16. 
Bazdrigianni, Maria (2006): "Diadromes istorikis mnimis". Agelioforos 25/03/2006, p. 19.

Bromley, Ray (2000): "Street Vending and Public Policy: A Global Review". International Journal of Sociology and Social Policy 20 (1/2), pp. 1-29.

Brown, Alison (ed.) (2006): Contested Space: Street Trading, Public Space, and Livelihoods in Developing Cities, Warwickshire: ITDG Publishing.

Castells, Manuel/Portes, Alejandro/Benton, Lauren A. (1989): “Conclusion: The Policy Implications of Informality". In: Alejandro Portes/Manuel Castells/Lauren A. Benton (eds.), The Informal Economy: Studies in Advanced and Less Developed Countries, Baltimore: John Hopkins University Press, pp. 298-312.

Cavounidis, Jennifer (2002): Characteristics of Migrants: the Greek Regularization Programme of 1998, Athens: Sakkoulas and National Labour Institute Athens.

Centeno, Miguel Ángel/Portes, Alejandro (2003): The Informal Economy: Studies in Advanced and Less Developed Countries, London: John Hopkins University Press.

Charisis, Dimitrios (2004): Open Letter (10/05/2004) (http://www.ac smi.gr/drasi_paremporio_KEEE.htm) [23/09/2005].

Cowan, Deborah/Bunce, Susannah (2006): "Competitive Cities and Secure Nations: Conflict and Convergence in Urban Waterfront Agendas after 9/11". International Journal of Urban and Regional Research 30 (2), pp. 427-439.

Cross, John C. (1998): “Co-optation, Competition, and Resistance: State and Street Vendors in Mexico City". Latin American Perspectives Issue 99, 25 (2), pp. 41-61.

Ekman, Jenny (1998): “Göteborg - The Friendly City. City Renewal Including Three Shipyards and Four Harbours". In: Association Internazionale de Navigation (ed.), Conference on Rehabilitation of Harbour Areas. Proceedings Lisbon, June 7-9, pp. 85-92.

EUROSTAT (2006): http://epp.eurostat.cec.eu.int [27/02/2006].

Fakiolas, Rossetos (1999): "Socio-Economic Effects of Immigration in Greece”. Journal of European Social Policy 9 (3), pp. 211-229.

Fakiolas, Rossetos (2002): "Migration and Unregistered Labour in the Greek Economy". In: Russel King/Gabriella Lazaridis (eds.), Eldorado or Fortress? Migration in Southern Europe, Houndmills/New York: Palgrave Macmillan, pp. 57-78.

Gordon, David (1997): "Managing the Changing Political Environment in Urban Waterfront Redevelopment”. Urban Studies 34 (1), pp. 6183. 
Gospodini, Aspa (2001): "Urban Waterfront Redevelopment in Greek Cities. A Framework for Redesigning Space”. Cities 18 (5), pp. 285 295.

Greiner, Clemens (2003): Der urbane Straßenhandel: eine wirtschaftsethnologische Analyse, Hamburg: unpublished master thesis.

Hatziprokopiou, Panos (2004): "Balkan Immigrants in the Greek City of Thessaloniki. Local Processes of Incorporation in an International Perspective". European Urban and Regional Studies 11 (4), pp. 321338.

Harvey, David (1973): Social Justice and the City, London: Arnold.

Harvey, David (1993): "From Space to Place and Back Again: Reflections on the Conditions of Postmodernity". In: Jon Bird et al. (eds.), Mapping the Futures: Local Cultures, Global Change, London et al.: Routledge, pp. 3-29.

Hoyle, Brian S./Pinder, David A./Husain, M. Sohail (eds.) (1988): Revitalising the Waterfront: International Dimensions of Dockland Development, London: Belhaven.

International Social Service (2002): Guide of Agencies and Services for Asylum Seekers and Refugees, Athens.

Jacobsen, Karen (2005): The Economic Life of Refugees, Bloomfield: Kumarian Press.

Kloosterman, Robert/Rath, Jan (2003): "Introduction". In: Robert Kloosterman/Jan Rath (eds.), Immigrant Entrepreneurs: Venturing Abroad in the Age of Globalization, Oxford/New York: Berg, pp. 116.

Komlosy, Andrea/Parnreiter, Christof/Stacher, Irene/Zimmermann, Susan (eds.) (1997): Ungeregelt und unterbezahlt: Der informelle Sektor in der Weltwirtschaft, Frankfurt/Vienna: Brandes \& Aspel.

Läpple, Dieter (1994): "Hafenwirtschaft". Handwörterbuch der Raumforschung und Raumordnung, Hanover: Akademie für Raumforschung und Landesplanung, pp. 462-467.

Lazaridis, Gabriela/Koumandraki, Maria (2003): "Survival Ethnic Entrepreneurs in Greece: A Mosaic of Informal and Formal Business Activities". Sociological Research Online 8 (2) (http://www.socres online.org.uk/8/2/lazaridis.html) [03/05/2005].

Lefèbvre, Henri (1994): The Production of Space, Oxford et al.: Blackwell.

Lyons, Michal/Snoxell, Simon (2005): "Sustainable Urban Livelihoods and Market-place Social Capital: a comparative study of West African traders". Urban Studies 42 (8), pp. 1301-1320.

Malone, Patrick (ed.) (1997): City, Capital and Water, London/New York: Routledge. 
Matalas, Antonia-Leda/Yannakoulia, Mary (2000): “Greek Street Food Vending: An Old Habit Turned New”. World Nutritional Diet 86, pp. 1-24.

Marshall, Richard (ed.) (2001): Waterfronts in Post-Industrial Cities, London/New York: Spon Press.

McGee, Terry G./Yeung, Yue-man (1977): Hawkers in Southeast Asian Cities: Planning for the Bazar Economy, Ottawa: International Development Research Centre.

Mestheneos, Elizabeth (2000): EU-Care: Refugee Entrepreneurs in Greece. National Contribution to the EU funded programme for the European Commission Directorate General Justice and Home Affairs (www.sextant.gr).

Mestheneos, Elizabeth (2002): "Foreigners". In: Richard Clogg (ed.): Minorities in Greece, London: Hurst \& Company, pp. 179-194.

Middleton, Alan (2003): "Informal Traders and Planners in the Regeneration of Historic City Centres: The Case of Quito, Ecuador". Progress in Planning 59 (2), pp. 71-123.

OECD (2005): The Economic Impact of Immigration. In: OECD (ed.), Economic Surveys: Greece, pp. 117-140 (www.oecd.org) [24/03/2006].

Papadopoulou, Aspasia (2003): “'Give us Asylum and Help us Leave the Country!' Kurdish Asylum Seekers in Greece and the Politics of Reception". Immigrants \& Minorities 22 (2/3), pp. 346-361.

Reyneri, Emilio (2001): Migrants Involvement in Irregular Employment in the Mediterranean Countries of the European Union (International Migration Papers of the ILO) (www.ilo.org).

Rodrigue, Jean-Paul/Comtois, Claude/Slack, Brian: The geography of transport systems (http://www.geog.umontreal.ca/Geotrans/fr/ch3fr/ conc3fr/ ch3c3fr.html) [01/11/2006].

Rogerson, Christian M. (1989): "The Underdevelopment of the Informal Sector: Street Hawking in Johannesburg, South Africa”. Urban Geography 9, pp. 549-567.

Rosewarne, Stuart/Groutsis, Dimitra (2003): "Challenges to the Integrity of a European Migration Program: Greece as the Recalcitrant State" (National Europe Centre Paper 75). Paper presented to conference 'The Challenges of Immigration and Integration in the European Union and Australia', 18-20. February 2003, University of Sydney, Sidney.

Schubert, Dirk (2001): "Revitalisierung von (brachgefallenen) Hafenund Uferzonen in Seehäfen - Anlässe, Ziele und Ergebnisse sowie Forschungsansätze und -defizite". In: Dirk Schubert (ed.): Hafen- 
und Uferzonen im Wandel: Analysen und Planungen zur Revitalisierung der Waterfront in Hafenstädten, Berlin: Leue, pp. 15-36.

Skordas, Achilles/Sitaropoulos, Nicholas (2004): "Why Greece is not a

Safe Host Country for Refugees". International Journal of Refugee Law 16 (1), pp. 25-52.

Social Solidarity (ed.) (2004): Evaluation of Incoming and Outgoing Refugee Population, Thessaloniki (unpublished).

Stoller, Paul (2002): Money Has no Smell. The Africanization of New York City, Chicago/London: University of Chicago Press.

Stroux, Salinia (2006): Afghan, Iranian and Iraqi Street Vendors in Thessaloniki, Greece: Street Vending as Survival Entrepreneurship, Hamburg: unpublished master thesis.

Stroux, Salinia (2002): "Ethnographic Field Report: Thessaloniki". In: Waltraud Kokot (ed.), European Port Cities: Disadvantaged Urban Areas in Transition. A Collaborative Project under the EU Transnational Exchange Programme ("Fight against Poverty and Social Exclusion”), Final Report - Phase 1 (www.europeanportcities.de), pp. 88-109.

Thessaloniki Port Authority (ed.) (2002): Handbook, Thessaloniki.

To Bimạ (Greek daily newspaper) 29/09/2002, p. 44.

Tsaktsira, Lambrou (1997): Stin Thessaloniki: Me meridiabasi, me logo kai ikona, Thessaloniki/Athens: Malliaris Paidia.

Tsoulouvis, Lefteris (1998): "Planning the Urban System and New Forms of Inequality in Greek Cities". Progress in Planning 50 (1), pp. 1-74.

UNHCR (2005): Statistics (www.unhcr.ch).

Valenzuela, Abel Jr. (2001): "Day Labourers as Entrepreneurs?” Journal of Ethnic and Migration Studies 27 (2), pp. 335-352.

Williams, Allan M./Baláž, Vladimir (2005): "Winning. Then Losing, the Battle with Globalization: Vietnamese Petty Traders in Slovakia". International Journal of Urban and Regional Research 29 (3), pp. 533-549.

Zouka, Barbara (2003): “4,4 ekat. Euro gia parembaseis se oli tin poli”. Macedonia 02/04/2003, p. 18. 



\section{Varna, Capital of the Sea: History, Image, and Waterfront Development}

\section{ANKE BOTHFELD}

Varna is situated in northern Bulgaria at the shores of the Black Sea and the Varna Lake. Its port is the biggest in Bulgaria, consisting of the ports of Varna-West at the banks of the Varna-Lake and Varna-East in and around the city centre. The outmoded facilities of Varna-East seem to confirm the model of city-port development presented by Hoyle (1989, see also Schubert in this volume), but they still handle one third of the transhipment of the harbour. A new container terminal will be built quite close to the inner city, thus Varna differs slightly from the model ${ }^{1}$, which pictures inner city renewal in port cities as a consequence of global technological development, concerning wastelands which are left behind by prospering harbours. While in Varna the inner city is also undergoing rapid transformations, turning from decay to renewal, this development is connected to an image of "centrality", for which the nearby port and the lake are of no relevance, as they seem to provoke

1 Deviations from Hoyle's (1989) model could possibly be explained with historical delay, but port development is more complicated and depends on local and international relationships between ports, as well as on technological development. The relationship between the city and the port is another important factor. In Varna, the port underlies not city administration, but state authority. This results in severe restrictions to inner city development by port functions (on Montevideo compare Zillmann 2002; Gandelsman-Trier, this volume). Kokot, this volume, stresses differences between European and Latin American port cities. The development of the port is very likely also related to the history of the city - whether it is more a colonial or a mercantile, maybe more a regal city or a city-state (on this typology compare Fox 1977).

2 "Image" in this context is used in the meaning of "label" or "brand" and thus deals with the marketability of the quarter. 
mainly negative associations. Above all, Varna is not so much known as a port city, but as the centre of the northern seaside resorts and often referred to as "morskata stolitsa" (Capital of the Sea). While the developments in the centre are not publicly debated, the use of space in a popular public park stretching along the beach, the "morskata gradina" (Sea Garden), is contested and vividly discussed.

This article deals with water-related images in the context of waterfront development in Varna. Geographer Jacques Charlier describes the relationship between port and city as struggle in which, at least in western Europe, urban key decision makers are suffering from what he calls "dockland syndrome". Following the example of the London Docklands, the potential of inner city ports for modernisation is frequently overlooked, and they are readily abandoned in favour of gentrification (Charlier 1992: 137, 140-142). Thus, the image of the de-industrialised city emerges as an important driving force, accompanying or even overruling the force of technological development, in turn employing waterrelated images to advertise the inner city districts (on the use of "water" in image-building of cities: Tölle 2005, Wildner in this volume).

In Varna, however, although the development of the city's waterfront differs from Hoyle's model, water-related images do play an important role.

Interrelationships between water, marketable images and local differences become especially visible in the context of a twin-town partnership project which links the cities of Hamburg (district Eimsbüttel) and Varna. The beginning of my research project coincided with the establishment of a group of city planners from Hamburg in the framework of the town partnership. They visited Varna several times since November 2005 to organise a redevelopment project in Varna. This cooperation offers unique possibilities to introduce elements for ethnography and comparison ${ }^{3}$, as Hamburg seems a prototypical case for Hoyle's model (compare Schubert and Dohrn in this volume, and Schubert 2002c on differences).

Hamburg and its port developed as a typical mercantile city (compare the typology of Fox 1977: 92-95) and maintained relative independence of state authority until the late $19^{\text {th }}$ century. In the face of the withdrawal of port functions, the northern bank of the Elbe now is constructed as a "pearl necklace" ("Perlenkette") of architecture. Its eastern end consists of the "HafenCity", a developing residential and business district, following the example of the London Docklands (Schubert

3 See Nader's "comparative consciousness" (1993) and Marcus' "multi sited ethnography” (2005). 
2002c: 151 and in this volume). The project integrates spaces of the old port and the old warehouse district, with a growing heritage industry marketing Hamburg's image as a port city (compare Turnbridge/ Ashworth 1992).4 These transitions are accompanied with gentrification processes. The old, (in)famous sailortown of St. Pauli has been the target of gentrification since the late eighties, and in the last years the north eastern rim of the port was also discovered for redevelopments.

In the following article, I shall highlight developments in Varna against the perspective of the Hamburg experts, who show a vivid interest in the waterfront of Varna. A Hamburg tourism expert even offered plans to export an important Hamburg festival, the "Hafengeburtstag", to Varna. In the course of my research, I took part in official and less formal meetings of experts from Hamburg and Varna experts in 2005 and 2006, in Varna and Hamburg. My analysis is based on these observations, on interviews and conversations with experts and with inhabitants of Varna, as well as on many walks through the inner city and discussions in the biggest local daily newspaper, the "Cherno More" ("Black Sea") 6 . This article analyses waterfront development in Varna as the result of local history and culture as well of global developments and transnational discussions.

\section{Odessos/Varna: The historical development of Bulgaria's biggest port}

Varna was founded as the Greek colony Odessos in 517 B.C. In the second century it was integrated in the Roman Empire, heading a regional network of five towns and ports. During the First Bulgarian Empire, the name Odessos was changed to Varna (Zheleva-Martins 2002: 76f.). After a short Byzantine period and the split of the Second Bulgarian Empire, Varna became the second biggest city of the north eastern part. ${ }^{7}$ By

4 I myself worked in the realm of this heritage industry as a shop assistant in the Speicherstadtmuseum, where I found the possibility to discuss some of these ideas. Especially engaged was my friend and colleague Stefan Rose whom we now miss severely since he passed on in April 2007 at the age of thirty three.

5 Birthday of the port; celebrated as a big tourist attraction every year in Hamburg; compare Kokot in this volume.

6 I used mainly the internet edition, see www.chernomore.bg.[23/02/2008]. The archive where I found articles from before 2005, however, was closed in December 2006.

7 For an interesting overview about the history of Varna, see http://varna. info.bg, [23/02/2008]. Currently, only the bulgarian Version works. 
trading with Genoa, Varna developed into a wealthy mercantile city, until it was incorporated in the emerging Ottoman Empire in 1393. Trade declined and grew again slowly since the middle of the $17^{\text {th }}$ century. In 1839, the Ottoman Empire permitted trade with Western Europe. Varna was integrated in the European railway network. With the growing traffic of trading vessels, and due to the interests of mainly English trading companies, two quays were built in the bay. After Bulgaria had gained independence, the Bulgarian ports remained under state administration. In Varna, a channel was constructed to connect the Varna Lake to the sea, where port facilities were built. The quality of the work changed essentially, since boats were no longer needed to ship the goods to and from the vessels (Stojanov 1992: 65f, 10).

After the First World War, the Dobrudcha, in the north-east of Bulgaria, fell to Romania, the Russian Empire collapsed, and the port of Varna lost its hinterland and the Russian traffic. Burgas in the South became the most important Bulgarian port (Stojanov 2003: 47). After the Second World War, in spite of restrictions on residence issued in 1955, Varna grew from 110,000 to 260,000 inhabitants between 1945 und 1975 (Koleva 2005: 121). This growth was the most significant in Bulgaria and corresponded to a general trend in Eastern Europe, where under communism port cities grew particularly fast (Hamilton 1980: 170, 180f.). The trend holds until now: 320,000 inhabitants, reaching 500,000 with the seasonal workers in summer, make Varna the third biggest city of Bulgaria (Spored danni ... 2006).

In 1966 a passenger terminal was built on the pier which separates the port facilities from the beach (compare Fig. 1, point 3). ${ }^{8}$

In the 1970s, because of tensions between the USSR and Romania a ferryboat terminal was built at the western shore of the Varna Lake, almost $30 \mathrm{~km}$ away from the sea, mainly for traffic to Odessa. The importance of the port of Varna grew again, but the inner city quays of Varna-East were never modernised. Containerisation was not widespread in the Soviet port system (Hall 1992: 106f.), although this was not only a socialist/Eastern European phenomenon: Also the ports in the Mediterranean were less involved in the global development of containerisation (Riley/Shurmer-Smith 1992: 82).

8 For port development in Varna see http://www.port-varna.bg, [23/02/ 2008]. 


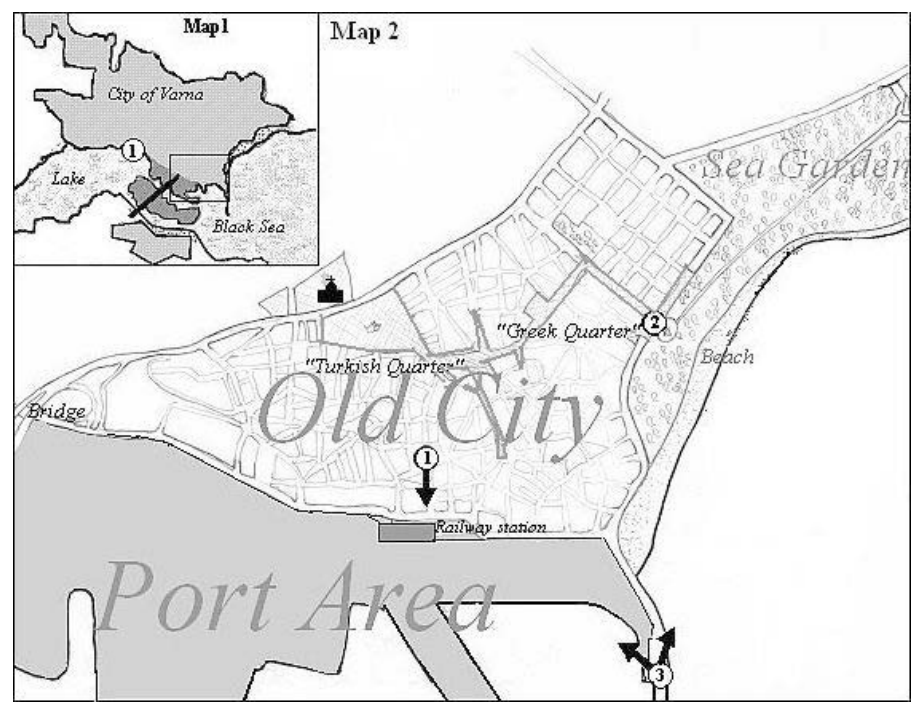

Fig. 1: Varna (maps: Anke Bothfeld)

In Varna, traffic peaked in 1989, but in the 1990s, once again, the collapse of the political system in the east left the port in trouble. Only in 2005 , traffic reached again the volume of 1989. In neighbouring Constanța (Romania) new port facilities were developed after the Danube channel was completed in 1984 (Hall 1992: 108). Since 1996, they are being modernised for container traffic. A hub-and-spokes-system evolves: Big container shipping companies call mainly at Constanța which guarantees fast loading and unloading and thus figures as a "hub", while Varna is almost only served by feeder lines, whose smaller ships are linking the hub with the peripheral ports (Hayuth/Hilling 1992: 48). Varna shipping companies already close their offices and reopen them in Constanța (Marashlieva 2006). Varna's port is also again in danger of losing its position to Burgas because of a new pipeline for Caucasian oil. But Varna's roro-facilities are still an important part of the shipping routes in the Black Sea (Tokman 2006: 3). Also, the shipyards are described as a booming industry (Zaradi aktsite ... 2006; Ganeva 2006).

As the case of Varna illustrates, containerisation means a hierarchy of ports by a hub-and-spokes-system, and global technological development does not only mean containerisation, but also specialisation (Hayuth/Hilling 1992: 45-48).

But historical and local factors, as well as regional and national politics, are likely to determine the development of a port at least as much as global technological developments. The Bulgarian ports are 
administrated by the state. This makes the planning for the city of Varna even more difficult. The city and the ministry of transport both are looking forward to the closing of most of the outmoded inner city facilities. But in the face of containerisation, national and local shipping agencies demand the rise of transfer traffic (Marashlieva 2006). At the end of 2006, a decision was made about further developments. A new container terminal will be built in the inner city because the biggest container ships can not pass the channel bridge. Also, new facilities for grain are planned. The port company owns land close to the city centre and wants to use it (Shterev 2006). An old railway station could be reopened and integrated (see Fig. 1, point 1). Representatives of the city argue against this: They hold that this area was too close to the living quarters, and that the general development plan from 1997 allowed only for green space (Davat ... 2006; Veltcheva 2006). ${ }^{9}$

\section{The Port of Varna: Images}

A cosmopolitan population and cultural diversity are integral parts of the image of port cities (Hilling 1988: 23f.). Such diversity also existed in Varna: People in or from the city ${ }^{10}$ mentioned a "Greek quarter" and an "Armenian quarter" in the old inner city, the former relating to more than two millennia of history, the latter still quite visible with a well-frequented Armenian church. The oldest Bulgarian orthodox churches are also to be found in this area, along with the ruins of a Catholic church, and the remains of the Ashkenazi and Sephardic synagogues. North of the centre, historical maps show a residential quarter of Crimean Tatars (Nedelchev 2005: 4f.) who fled to the Ottoman Empire via the port of Varna in the 1850s-60s (Williams 2001: 209-12). While these groups could be linked to Varna's history as a port city and trading centre, the Turkish minority is the biggest one in Bulgaria today, with approximately $10 \%$ of the population, but the expression "Turkish quarter" used in the city museum refers only to the western part of the old city which was built under Ottoman rule. ${ }^{11}$ Several ethnic groups are stigmatised

9 This idea stems from the 1970 s when a marina was planned there (Milko ... 2006).

10 A Varnaian architect, another former resident of Varna in Hamburg as well as an employee of the Varnaian Eimsbüttel-Büro and two passers-by who offered to show me around in Varna.

11 Many Turks left the newly founded Bulgaria in the 1880 s, and again in the 1980 s during the campaign to Bulgarise the Turkish- and Romani-Bulgarian population. 
under the label "Tsigani" (gypsies), who with at least 3\% are Bulgaria's second biggest ethnic minority. Maksuda in the west of the centre, close to the port and to the old railway station, is known as a Romani quarter ${ }^{12}$ and is labelled as a dangerous, drug-dealing site in the newspaper as well as by residents in Varna. ${ }^{13}$

Closely interlinked with the image of cosmopolitanism is the stereotype of an interesting "sailortown". The historian Petar Stojanov pictures scenes of sailors seeking adventures in the company of women for the sailortown of Varna of the 1880s (Stojanov 1992: 66). They are also to be found in texts which more generally relate positively to the sailortown as "maritime heritage" (Schubert 2002b: 29) or celebrate it with romanticism and melancholy (Hilling 1988: 33). Even official texts of the Hamburgian senate use this image of romantic adventures to advertise for renewal of St. Pauli (Kossak 1987). In respect to Varna, experts from Hamburg voted to rid the inner city of the noisy and dirty port facilities, making room for a charming district ${ }^{14}$, thus illustrating Schubert's description of this transformation process (Schubert 2002a: 12), as well as Charlier's (1992) notion of a struggle between port and city about space, rather than inevitable development.

The contrast between perceptions in Hamburg and Varna perception is striking. People in or from Varna denied the existence of a sailortown. When asked in interviews, they only referred to the Greek quarter, or to the space around the railway station, which indeed borders directly to port facilities. The area was described as dirty, and as a dead edge. The presence of "strangers" and Roma in this area is seen as a negative factor. When one interviewee showed me the flat of a relative on a map, she was quite upset when I mentioned the close neighbourhood to the port and explained that this only looked that way on the map, but in reality both quarters had nothing to do with each other. ${ }^{15}$ Perceptions of the port-related area in Varna - dirt, danger and strangers - thus reflect those elements of the old sailortowns, which are not likely to be mar-

12 Many Roma live there in illegal squatter settlements which emerged in the 1990s (Khristov 2006).

13 One morning, my landlord warned me not to enter Maksuda, and during a evening festivity, both female employees of the Varnaian Eimsbüttel-Büro said that they would never go there (02-03/11/2006). On drug-dealing, see for example Draganov 2006.

14 During a walk in Varna 11/11/2005 and in two interviews conducted in Hamburg 10-11/04/2006.

15 Explanations by passers-by, a landlady, shopkeepers and waitresses I asked in Varna; interview with a former resident in Hamburg 10/10/2005. as well as with an employee of the Varnaian Eimsbüttel-Büro 04/11/2005. On a similar perception of the centre in Sofia see Varzonovtsev 2002: 125. 
keted as tourist attractions (Hilling 1988: 35). In this context, the rapid renewal of the adjoining area, the restoration of old buildings and the construction of new ones, as well as the exorbitant rise of real estate prices in the central part of the town have developed not because of, but in spite of the proximity of the port. ${ }^{16}$ Although one expensive hotel facing the depot west of the railway station is called "Aqua", all in all the rapid construction is not related to waterfront renewal, but reflects a recent process in many post-socialist cities, where old buildings had been rotting away for decades. ${ }^{17}$

The port and ships are by no means absent from the picture of Varna, however. Cranes and machinery can be seen from the eastern part of the old town. ${ }^{18}$

Men dressed in working gear are passing through the controlled gateways for lunch in cheap restaurants around. Shops and stalls offer the usual souvenirs, and port-related names and signs are to be found in bars and restaurants. In the streets nearby custom agencies and shipping companies are located. One of them resides in an old, restored warehouse from the 1850s. Two monuments from socialist times picture the port: a concrete ship reminds of the departure of Georgij Dimitroff for the Second World Congress of the Comintern 1920, and the "Pantheon" in the Sea Garden dedicated to resistance against fascism, shows also port scenes. In the middle of the old town, a building in the shape of a sail had been planned in the 1970s for the regional parliament (Arkhitekti ... 2006). The navy museum, also from the communist era, exhibits in its garden the Draski, a ship which is well known in Bulgaria for its participation in a battle against Ottoman troops in 1913. The naval academy dominates the eastern skyline of the city, and in the centre nearby the cathedral new recruits of the navy are sworn in (Stotitsi ... 2006). Thus, the port works in the middle of the city, but it is represented as a national institution. When the port's $100^{\text {th }}$ birthday was celebrated in May 2006, this was mentioned only twice in the Cherno More. Under the title "Three hundred VIP-guests celebrate at the passenger terminal" the Prime Minister, the Transport Minister and the director of the port administration as well as representatives of European ports were

16 Compare Blum on Lisboa, where inner city planners ignored the southern bank of the Tejo because of its industrial image. (2007: 47; 50-51).

17 On the necessity of a multifaceted approach to inner city transition compare Gandelsman-Trier in this volume. For further cases of post-socialist inner city development compare Gdaniec 2005 on Moscow. Of course, crumbling inner cities are known also from western contexts. It is the timing which links the post-socialist cases. Whether this development is to be called gentrification remains to be discussed.

18 See point 1 in map 2. 
named, and the cultural programme was organised by the navy (Marinova 2006a). Some sentences comment on a photograph of the Transport Minister and a small monument in honour of the birthday (Aleksieva 2006b).

The plans for the area, which will be left behind when the port moves, are unrelated to the area's "heritage". Shops, offices, exhibition halls and a new aquarium are planned. Central for the project will be the enlargement of the passenger terminal and the construction of a big marina (Shterev 2006). The city will host the Cutty Sark Race in 2008, the newspaper includes a section on sailing. As an expert from Varna stated, two German festivals which consist mainly of sailing events are supposed to serve as models for new festivals, and a Varna expert for youth and sports supports the organisation of international regatta events in Varna. ${ }^{19}$

Comparing the plans for Varna to the Hamburg HafenCity, a Varna architect announced that Varna is aiming mainly at tourism. ${ }^{20}$ The new plans for the inner city are not explicitly seen as new uses for an old port area, but as a shining extension of the beach reaching out from the east (Marinova 2006b), and as an opportunity to bring together the city and the sea (Nestorov 2006).

\section{Varna, tourism and the Sea Garden}

Waterfront redevelopment often employs water as a "soft factor" in advertising a given city or quarter (Tölle 2005: 187). This does not only work in port cities or in old port areas. Water now is generally expected to add to the prestige of places, and to offer exciting chances for architecture (Tölle 2005: 88; Schubert 2002b: 15). In the case of Varna though, such hopes seem to have been disappointed. While Varna not only stretches along the shore of the Black Sea, but also along the eastern part of the Varna Lake, the lake not only lacks positive connotations, but has, like the port, even an explicitly negative image. In my interviews respondents stated that "gypsies are living there", while the lake itself is considered as polluted by various industries. Even the view to

19 During an official dinner with the Hamburgian experts in Varna, 01/11/2006. See also Vetrokhodtsi ... 2007.

20 Interview in Hamburg 13/04/2006. In general, while in socialist times the necessity of mixed use of Varna's city centre was stressed (Glucharov/Evrev 1980), new planning discussions do away with residential functions and emphasise administration, tourism and business as main functions (V tsentera ... 2006). 
the water from a luxurious gated development in the hills, once praised in an English advertisement as "sea view", was declared as less attractive because one could only see the lake and not the Black Sea. ${ }^{21}$

The sea, in contrast, is central to the image of Varna. This image in turn was central for the development of the city when the port lost its position between the wars. Structures for tourism were expanded, and Varna became the cultural and economic centre of the seaside resorts in northern Bulgaria and the whole region (Stojanov 2003: 29, 47, 75). In socialist Bulgaria, the economic meaning of tourism was not officially admitted, but the tourist industry was developed systematically. The seaside resorts became the "Red Riviera" which was also visited by tourists from the capitalist countries. Anthropologist Kristen Ghodsee describes wealth and the possibility to meet strangers as qualities of Bulgarian tourism, which often are associated with port cities: (Ghodsee 2005: 86$89,97) .{ }^{22}$ Since the 1920 s, Varna has been offering much more than just beach life to the tourists. The annual summer festival of music, a big and popular event, was installed at the time. There are also several other festivals of playacting, movies, graphics, and so on, many of them dealing with the sea. August $8^{\text {th }}$ is the Day of the Fleet, an annual festival is called "The Sea and Memories", art galleries present theme-orientated exhibitions, and on January $7^{\text {th }}$, a new year swimming event takes place in the bay.

Consequently, the Hamburg idea of introducing a "Hafengeburtstag" (port birthday) to Varna was changed in 2005. The event is now called "Europäisches Meeresfestival Darsalei" ("European Festival of the Sea Darsalei”) and is placed in the last week of May (Varna-Büro 2007). As one of the Hamburg experts related ${ }^{23}$, this name is based on an explicit invention of tradition: Asked for a suitable historical precedent, a historian at the Varna archaeological museum came up with a marketable event: In the Odessos of the roman times, games were held in honour of a Thracian god named Darsalas. The fact that these took place in winter (Khristova 2006a) seemed like a minor flaw in the face of the exciting possibilities for marketing the god as a symbol for the city: The expert even suggested a special hymn and a musical. The "Cherno More" praised this initiative (Ot ... 2006) and announced a contest to design

21 In a discussion on the side during a meeting in Varna 03/11/2006.

22 Compare Hilling 1988: 35 about tourists, who are now the customers of the old sailertowns.

23 In a public meeting in Hamburg/Eimsbüttel devoted to the "Varna-Kreis" 30/01/2006. 
Bulgarian mascots, one of them symbolising Varna and based on Darsalas (Tsolova 2006). ${ }^{24}$

According to the Hamburg expert, such a festival would change the main inner city streets to prestigious boulevards and "clean up" the adjoining streets. Already in the 1970s, a small part of the inner city had been changed significantly for touristic use. Some streets were beautifully restored and closed for cars (Pfau 1980: 613, compare the hatched area in the old city in Fig. 1).

Most cultural events are not taking place in the inner city, but in the morskata gradina, the Sea Garden. This park is more than anything else an object of desire in Varna. Its first paths were laid out under Ottoman rule in 1863. In the 1890s the well-known Czech garden architect Anton Novak planned many of the contemporary elements of the park (Stojanov 1992: 49), which was linked to the inner city with an impressive gate in $1939 .^{25}$

There, stretching from the pier almost eight kilometres eastward, the park widens far enough to make forget the surrounding traffic. From here, it follows the steep coast, and parallels the residential quarter Primorski, which has been prestigious in socialist times. Stairways, sometimes dangerously damaged, link the park to the beach, which in summer is accessible only in some areas because of license holders who build restaurants, cafés and discotheques right in the sand. In the park, old trees and bushes block the vista onto the water, until a broad place around the Pantheon opens up the view to the sea.

The park, its relation to the city and to the sea and the use of its space was a major point of debate among the planning experts from Hamburg, who proposed two different solutions. ${ }^{26}$ One architect and urban planner claimed that the park was underused and suggested to break it up to introduce architectural links between the city and the sea, quoting the coastline of Barcelona and the Hamburg "Pearl Necklace" as examples of successful development. In his view, Varna is lacking "gelebte Urbanität von Stadt und Meer",27 because in Varna, the proximity of the sea cannot be seen from the city. Two of his colleagues did not approve of his idea. Warning that such a plan would rob Varna of a

24 This is not an entirely new idea: in 2001, a "Varna-Day" was installed and a Varna anthem was performed for the first time (Na Goljama ... 2001; Za parvi ... 2007), while the plans from Hamburg have been delayed. The first "Sea Festival" now is planned for 2008 (Varna-Büro 2007).

25 See point 2 in map 2.

26 They discussed this during walks through Varna and in the interviews in Hamburg and often returned to these arguments later.

27 "lived urbanity of the city and the sea" (Interview 12/04/2006). 
meaningful landmark and hence of an essential ingredient for a marketable image, they tried to direct the focus of waterfront development to the port facilities.

The experts thus discussed the aspect of water, or sea, in terms of image and urbanity, paralleling local debates in Varna. First and foremost, the role of the park for the inhabitants' identification with the city can hardly be overestimated (compare Lynch 1960). Without being explicitly asked, many of my interview partners mentioned the park in an affectionate way. The "centrality" of their own address was stressed by emphasising the short distance to the park entrance. ${ }^{28}$ The park was named as an important landmark of the city, as the ideal place for relaxing walks and as the city's defence against the cold winds from the sea. In two cases, though, women remarked that beyond a certain distance to the centre, they did not feel safe anymore. ${ }^{29}$ This corresponds to the use people made of the park. Even in November, the area of the entrance is full of people. Souvenirs, popcorn and beverages are sold. The cafés are expensive, but there are many public benches. Several leisure facilities, like a children's park, a zoo, and the dolphinarium, as well as institutions like the aquarium, the observatory and museums, public tennis courts and other sport facilities, a summer theatre, a new amphitheatre, as well as a part exclusively for mothers with small children are included in the park and groups of runners meet at the Pantheon. But further on in the eastern part, wide space remains empty in the off-season and adds a touch of abandonment.

Even so, plans for privatisation of the eastern sites of the park, and the construction of expensive and exclusive houses and hotels, have provoked angry reaction. Corruption is suspected to play its part in this emerging "Beverly Hills", as the area is called. The private use of space in the morskata gradina, as well as the mayor's opposition against it, are constant topics in the newspaper ${ }^{30}$, although to link the city with the sea via the park, does not necessarily mean privatisation. According to a Varnaian architect (interview November 2006) it could even put an end to the private licensing of beach sites and improve the integration of park and city.

28 Residents of Varna 04/11/2005; 01/11/2006.

29 Former resident in Hamburg 10/10/2005; resident in Varna 04/11/2005.

30 Similar discussions can be found in Burgas, where in a park at the sea apartment buildings are planned (Vdigat ... 2006). These processes must also be seen in the framework of the Bulgarian environment program "natura" which forbids buildings in the proximity of the shore, which in turn is criticised as a serious obstacle for tourism and a breeding ground for corruption. 
Besides being a place for leisure and relaxation and a link to the sea, the park is also a place where the history of Varna and Bulgaria is remembered. A broad, well-tended "Avenue of the Heroes of the Bulgarian National Rebirth" refers to the Bulgarian independence movement in the $19^{\text {th }}$ century. It is lined by sculptures, the first of which was uncovered in 1911, and leads directly to the socialist Pantheon. There has been a debate about the destruction of memorials from the communist time in Varna (Tonovski 2005), but so far, this led nowhere. ${ }^{31}$ A newer memorial reminds of Ukrainian soldiers dying in battles in 1444, 1878 and 1944 in behalf of Bulgaria. ${ }^{32}$ The park thus offers opportunities to passers-by to place their own biography in the history and geography of Varna and Bulgaria. In turn, the park has become a place of political culture. In the Avenue, the navy honors Bulgarian heroes, but also less official political events of every colour are taking place there. To name only a few, the right-wing organisation Ataka has organised demonstrations against the EU and the NATO, mothers protested against the closing of child care facilities, and a HIV-solidarity group which is quite active in Varna has erected a red ribbon two metres high.

The morskata gradina (Sea Garden) is a significant urban institution in Varna. Its name matches Varna's title "morskata stolitsa" (Capital of the Sea), adding to the image of the city as related to the sea. It also plays an important role in tourism, Varna's most reliable and most profitable sea-related branch of economy, and offers qualities which connect space with history and personal memories, as well as space for collective action or for social contacts. Thus, physical and administrative changes affecting the park are perceived as a threat and indeed are likely to restrain these uses (compare Wonneberger in this volume).

\section{Conclusion}

Varna does not fully match the stages of waterfront revitalisation as predicted by Hoyle's model. A focus on discussions among experts from Hamburg about the future of Varna shows, that port city renewal does

31 An interviewee pointed out that, although the communist regime was not to be romanticised, she is fond of the place because of its inseparable connection with her childhood memories of the many hours she spent there during rituals of the socialistic youth organisation (Hamburg,10/10/2006).

32 Also, in the course of planning, constructing and uncovering of the monument, contacts between Varnaian and Ukrainian officials were fostered (Pametnik ... 2006; Aleksieva 2006a). 
not develop "naturally", but also results from conflicts about contested space.

Images emerge as a driving force in waterfront revitalisation, both in the sense of stereotypes (or "syndromes" according to Charlier 1992) of certain types of cities, or in the sense of marketing or image-building. In stressing the "need for water" in Varna's image-building, the experts from Hamburg transported their experience from Hamburg to Bulgaria. Their perception of Varna focuses on belated development and deficits: the position of the port facilities seem outmoded, space seems underused, the lack of urbanity at the shore is criticised against the examples of Barcelona and Hamburg and marketing and festival strategies are introduced as new.

In Varna, as in Hamburg, water is closely associated with the city's history and the seaside resorts are an important factor in tourism. The morskata gradina is a place which physically and symbolically links Varna to the sea, offering opportunities to identify with the city and the nation. As one of Varna's most important public spaces, it is an important resource for tourism and hence economically relevant. Architectural links to the sea would on the one hand split up the wide green park landscape in the centre of the city, but on the other hand could help to reopen the beaches to the public.

As this paper shows, waterfront development differs in respect to local history, economy and political conditions, which again are connected with images. Schubert's (2002) call for the research of planning cultures and Charlier's word of the "dockland syndrome" offer interesting challenges to anthropological research: A focus on the cultural construction of the principles of waterfront revitalisation would imply ethnographic research among experts and key decision makers (compare Nader's "studying up" 1974).

Local factors do not alone determine the development of a given city. Urban planning (Bartley/Threadwell-Shine 2003: 161) and waterfront development (Tölle 2005: 1, 177) are, like the technological development of ports, international affairs (see Blum on Lisboa 2007: 47). Discussions about cities and waterfronts in a country like Bulgaria, which just has entered the European Union, therefore will add new perspectives to the study of image-building and of waterfront development.

\section{References}

Aleksieva, Nadeshda (2006a): "Photograph: Consul-general of the Ukraine in Varna”. Cherno More 15/04/2006. 
Aleksieva, Nadeshda (2006b): "Photograph of the transport minister and a small monument in honor of the birthday". Cherno More 19/05/2006.

"Arkhitekti umuvali badeshteto" (2006). Cherno More 28/07/2006.

Bartley, Brendan/Treadwell Shine, Kasey (2003): "Competetive City and the Changing Dynamics of Urban Regeneration in Dublin”. In: Frank Moulaert/Arantxa Rodríguez/Erik Swyngedouw (eds.), The Globalized City. Economic Restructuring and Social Polarization in European Cities, Oxford et al.: Oxford University Press, pp. 145166.

Berking, Helmuth/Löw, Martina (eds.) (2005): Die Wirklichkeit der Städte. Soziale Welt. Sonderband 16, Baden-Baden: Nomos.

Blum, Eva Maria (2007): "Planungskulturen im Konflikt. Stadtumbau im Großraum Lissabon”. Zeitschrift für Volkskunde 103 (1), pp. 3963.

Charlier, Jacques (1992): "The Regeneration of Old Port Areas for New Port Uses". In: Brian S. Hoyle/David A. Pinder (eds.), European Port Cities in Transition, London: Belhaven Press, pp. 137-154.

"Davat na kontsesija port Varna dogodina" (2006). Cherno More 07/12/2006.

Draganov, Dragomir (2006): “Zalovikha trima plasjori na kheroin v 'Maksuda"'. Cherno More 09/05/2006.

Fox, Richard G. (1977): Urban Anthropology: Cities in their Cultural Settings, Englewood Cliffs, N.J.: Prentice-Hall.

Ganeva, Svilena (2006): "Korabnijat naema na rabota 50 ukraintsi". Cherno More 07/12/2006.

Gdaniec, Cordula (2005): Kommunalka und Penthouse. Stadt und Stadtgesellschaft im postsowjetischen Moskau, Münster: Lit-Verlag.

Ghodsee, Kristen (2005): The Red Riviera. Gender, Tourism and Postsocialism on the Black Sea, London: Duke University Press.

Glucharov, Ivan/Evrev, Petko (1980): Zur Erneuerung der bulgarischen Städte. Architektur der DDR 29 (10), pp. 605-611.

Hall, Derek (1992): "East European Ports in a Restructured Europe”. In: Brian S. Hoyle/David A. Pinder (eds.), European Port Cities in Transition, London: Belhaven Press, pp. 98-115.

Hamilton, F.E. Ian (1980): "Urbanization in Socialist Eastern Europe: The Makro-Environment of Internal City Structure”. In: Richard A. French/F.E. Ian Hamilton (eds.), The Socialist City. Spatial Structure and Urban Policy, Chichester et al.: Wiley, pp. 167-193.

Hayuth, Yehuda/ Hilling, David (1992): “Technological Change and Seaport Development”. In: Brian S. Hoyle/David A. Pinder (eds.), 
European Port Cities in Transition, London: Belhaven Press, pp. 4058.

Hilling, David (1988): "Socio-Economic Change in the Maritime Quarter: the Demise of Sailortown". In: Brian S. Hoyle/David A. Pinder/M. S. Husain (eds.), Revitalising the Waterfront: International Dimensions of Dockland Redevelopment, London: Belhaven Press, pp. 20-37.

Hoyle, Brian S. (1989): “The Port-City Interface: Trend, Problems and Examples”. Geoforum 4, pp. 429-435.

Hoyle, Brian S./Pinder, David A. (1992): European Port Cities in Transition, London: Belhaven Press.

Khristov, Khristo (2006): "Maksuda ili Dereto: Upravnitsite shte gi butnem njama da gi butnem". Objektiv 134, pp. 27-28. (http://www. bghelsinki.org/obektiv/2006/134/134issue.pdf) [23/02/2006].

Khristova, Donka (2006a): "Predi 2500 godini v Odesos se provezhdali igri, naracheni Darsalei”. Cherno More 28/01/2006.

Khristova, Donka (2006b): "Otkrikha ukrainskija pametnik vav Varna". Cherno More 15/04/2006.

Khristova, Svetlana (ed.) (2002): Gradat: cimvoli, obrazi, identichnosti, Sofia: Lik.

Koleva, Daniela (2005): "Rural-Urban Migration in the Normal Biography”. Ethnologia Balkanica 9, pp. 115-131.

Kossak, Egbert (2000): "Leitlinien zur Entwicklung des nördlichen Elbufers". In: Freie und Hansestadt Hamburg, Behörde für Bau und Verkehr - Landesplanungsamt (ed.), Perlenkette. Hamburgs Hafenrand, Hamburg, pp. 28-29.

Löw, Martina (2006): "Immer einzig und überall gleich. Chancen und Risiken moderner Städte". Paper presented at "33. Römerberggespräch”, Frankfurt/M., 21 of January 2006 (http://raumsoz.ifs.tudarmstadt.de/forschung/fo03-vortraege/fo03-vortraege.html) [23/02/2008]

Lynch, Kevin (1960): The Image of the City, Cambridge, Mass.: MITPress.

Marashlieva, Albena (2006): "Morskijat ni biznes se iznasjal kam Konstantsa". Cherno More 14/07/2006.

Marcus, George E. (2005): “The Refashioning of Ethnography”. In: Helmuth Berking/Martina Löw (eds.), Die Wirklichkeit der Städte. Soziale Welt. Sonderband 16, Baden-Baden: Nomos, pp. 387-396.

Marinova, Violeta (2006a): "300 VIP gosti kuponjasvat na morska gara Varna”. Cherno More 12/05/2006.

Marinova, Violeta (2006b): "Dnes obsazhdat badeshteto na port VarnaIstok”. Cherno More 14/08/2006. 
Matuz, Josef (1985): Das Osmanische Reich. Die Grundlinien seiner Geschichte, Darmstadt: Wissenschaftliche Buchgesellschaft.

"Milko Minkov - bivsh rakovoditel na maketnoto atelie pri Rajonnata proektanska organizatsija, Varna" (2006). Cherno More 20/07/2006.

"Na Goljama Bogoroditsa e Denjat na Varna" (2001). Cherno More $15 / 08 / 2001$.

Nader, Laura (1974): "Up the Anthropologist - Perspectives Gained From Studying Up". In: Dell Hymes (ed.): Reinventing anthropology, Ann Arbor: Vintage Books, pp. 285-311.

Nader, Laura (1993): “Comparative Consciousness". In: Robert Borofsky (ed.), Assessing Cultural Anthropology, New York et al.: McGraw-Hill, pp. 85-96.

Nedelchev, Nikolai (2005): Varna dnes i vchera (do 1940), Varna: Slavena.

Nestorov, Rumen (2006): "Vzaimootnoshenijata v sistema 'grad - pristanishte' vav Varna sa na pat da izljasat ot omagjosanija krag". Cherno More 28/11/2006.

"Ot 2007, Varna shte privlicha turisti s morski evrofestival" (2006). Cherno More 25/01/2006.

"Pametnik na ukrainskite voini" (2006). Cherno More 26/01/2006.

Pfau, Wilfried (1980): "Zur Planung und Gestaltung von Wohngebieten in Varna". Architektur der DDR 29 (10), pp. 612-618.

Riley, Ray/Shurmer-Smith, Louis (1992): "Maritime Links, Seaport Systems and European Integration". In: Brian S. Hoyle/David A. Pinder (eds.), European Port Cities in Transition, London: Belhaven Press, pp. 80-97.

Schroer, Marcus (2005): "Stadt als Prozess. Zur Diskussion städtischer Leitbilder". In: Helmuth Berking/Martina Löw (eds.), Die Wirklichkeit der Städte. Soziale Welt. Sonderband 16, Baden-Baden: Nomos, pp. 327-344.

Schubert, Dirk (ed.) $\left(2002^{2}\right)$ : Hafen- und Uferzonen im Wandel. Analysen und Planungen zur Revitalisierung der Waterfront in Hafenstädten. Berlin: Leue.

Schubert, Dirk (2002 ${ }^{2}$ a): "Vorwort". In: Dirk Schubert (ed.): Hafen- und Uferzonen im Wandel. Analysen und Planungen zur Revitalisierung der Waterfront in Hafenstädten. Berlin: Leue, pp. 11-14.

Schubert, Dirk (2002 ${ }^{2}$ b): "Revitalisierung von (brachgefallenen) Hafenund Uferzonen, Anlässe, Ziele, Ergebnisse sowie Forschungsansätze und -defizite". In: Dirk Schubert (ed.): Hafen- und Uferzonen im Wandel. Analysen und Planungen zur Revitalisierung der Waterfront in Hafenstädten. Berlin: Leue, pp. 15-36. 
Schubert, Dirk $\left(2002^{2} \mathrm{c}\right)$ : “'Neues von der Wasserkante' - Stadtumbau am nördlichen Elbufer in Hamburg”. In: Dirk Schubert (ed.): Hafenund Uferzonen im Wandel. Analysen und Planungen zur Revitalisierung der Waterfront in Hafenstädten. Berlin: Leue, pp. 135-157.

Shterev, Dimitar (2006): "Kap. Danail Papazov, izpalnitelen direktor na Pristanishte Varna EAD: 'Novijat port shte e pred Maksuda, a ne do, Kazashko"” Cherno More 23/12/2006.

"Spored danni ot politsijata: Sredno 500000 dushi zhivejat vav Varna" (2006). Cherno More 04/08/2006.

Stojanov, Petar (1992): Stara Varna v parvite godini sled osvobozhdenieto 1878-1890, Varna: Steno.

Stojanov, Petar (2003): Varna mezhdu dvete svetovni vojni, Varna: Steno.

"Stotitsi gledakha poslednata kletva na ploshtada" (2006). Cherno More 14/08/2006.

Tölle, Alexander (2005): Quartiersentwicklung an innerstädtischen Uferzonen. Die Beispiele Hamburg HafenCity, Lyon Confluence und Gdańsk młode miasto, Berlin: Leue.

Tokman, Georgiy (2006): Black Sea Region Ports on Modern Stage of Development of Transport Communications between Europe and Asia. Paper presented by the Executive Director of the Black and Azov Seas Ports Association (BASPA) at the International Conference on the Black Sea Traffic, November 2006, Sofia. (http://www. port.bg/conference/presentation/BlackSea.pdf) [23/02/2008].

Tonovski, Vasil (2005): "Bogove, grobnitsi ...". Cherno More $10 / 11 / 2005$, p. 2.

Tsolova, Vania (2006): "Majstori se sastezavat za naj-atraktiven suvenir na Varna i Balgarija”. Cherno More 30/06/2006.

Turnbridge, John/Ashworth, Gregory (1992): "Leisure Resource Development in Cityport Revitalisation: the Tourist-Historic Dimension". In: Brian S. Hoyle/David A. Pinder (eds.), European Port Cities in Transition, London: Belhaven Press, pp. 176-200.

"V tsentera na Varna - samo turizm, upravlenie i biznes" (2006). Cherno More 03/05/2006.

Varna-Büro (2005): Kooperation Eimsbüttel-Varna. Bericht aus dem Bezirksamt vom 28.4.2005. (http://fhh.hamburg.de/stadt/Aktuell /bezirke/eimsbuettel/varna-bericht1,property=source.pdf) [23/02/2008]

Varzonovtsev, Dmitrij (2002): "Stolichnijat tsentar - choveshka perspektiva (Opit za sjuzhetno roleva rekonstruktsija)". In: Svetlana Khristova (ed.), Gradat: cimvoli, obrazi, identichnosti, Sofia: Lik, pp. 122-129. 
"Vdigat blokove v Morskata gradina" (2006). Standart 01/11/2006, p. 6.

Veltsheva, Svilena (2006): "Projektirat Asparuchov Moct II s novija terminal na porta”. Cherno More 15/12/2006.

"Vetrokhodtsi ot pobratimenite c Varna gradove idvat za regati" (2007). Cherno More 18/01/2007.

Williams, Brian Glyn (2001): The Crimean Tatars: The Diaspora Experience and the Forging of a Nation, Leiden: Brill.

"Za parvi pat izpalnikha novija khimn na grada" (2007). Cherno More 16/08/2007.

"Zaradi aktsite na KRZ 'Odesos' indeksat na borcata udari rekord" (2006). Cherno More 19/07/2006.

Zheleva-Martins, Dobrina (2002): "Strukturnijat analiz pri izsledvane na istoricheskite gradove". In: Svetlana Khristova (ed.), Gradat: cimvoli, obrazi, identichnosti, Sofia: Lik, pp. 70-88.

Zillmann, Kerstin $\left(2002^{2}\right)$ : "Montevideo. Die Stadt am Hafen? Die Revitalisierung der Bucht und der Plan Fénix”. In: Dirk Schubert (ed.): Hafen- und Uferzonen im Wandel. Analysen und Planungen zur Revitalisierung der Waterfront in Hafenstädten. Berlin: Leue, pp. 401-417. 



\section{"Istanbul Modern" - Urban Images, Planning Processes and the Production of Space in Istanbul's Port Area}

\section{KATHRIN WILDNER}

Thinking about Istanbul, one of the first images coming to mind is that of water. Istanbul is surrounded by water. Water is part of the topographic landscape; it separates the city and connects the different waterfronts. Throughout its history, water in Istanbul has meant transportation, defence and economy, and since antiquity the shores have been locations for harbour activities, trade or recreation. The silhouette of the city, with its hilly urban landscapes, bridges, mosques and minarets seen from the Bosporus is one of the most reproduced images of the city. There are reams of poetry, songs and other narrations about the waterfront, silhouettes and vistas of Istanbul.

By the Bosporus and the Golden Horn Istanbul is divided into three parts. At the south side of the natural harbour of the Golden Horn, there is the so-called "historic peninsula". Beyond the historic city wall the city is expanding about $60 \mathrm{~km}$ to the west at the shores of the Marmara Sea, where at all times a huge number of boats is waiting for a place in the harbor areas or a passage through the Bosporus. The northern side of the Golden Horn, previously called "Galata" or "Pera", became known as the non-Muslim area for traders and diplomats. Today it is defined by the crowded and cosmopolitan centre around modern Taksim Square with its hotels, nightlife areas and shopping streets expanding further north to the new central business district, into canyons of poorer neighbourhoods and valleys of gated communities.

The Bosporus, a strait of about $30 \mathrm{~km}$ connecting the Mediterranean Sea and the Black Sea, divides the European and Asian parts of the metropolis. Similar to the extensions on the western side, at the eastern side 
the urban landscape is expanding along the Marmara Sea as a patchwork of old middle class and newer working class neighbourhoods, of commercial areas, shopping malls and new industrial port areas. At both shores of the Bosporus up to the Black Sea, former fishing villages and summer residences are incorporated into the city. The shores and scenic harbour areas now function as attractive living areas and touristy destinations alike.

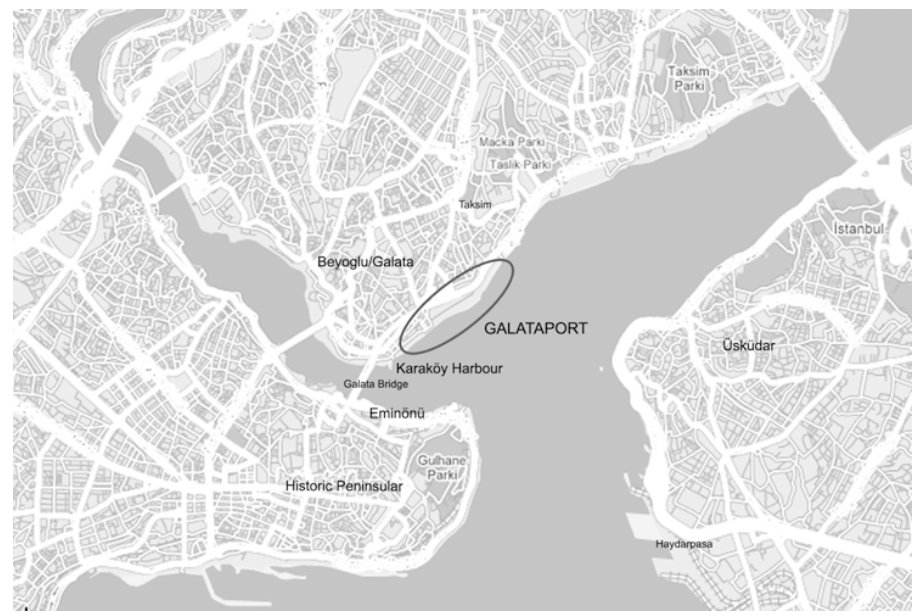

Fig. 1: Map of Istanbul with "Galataport Project" (graphic by Sacha Essayie)

From the beginning of the $20^{\text {th }}$ century industrialisation and modernisation have influenced the development of the historic port area of Istanbul. Even though the city grew extensively in the last 50 years, one main focus is still the area where the Golden Horn, the Bosporus and the Marmara Sea come together. At the beginning of the $21^{\text {st }}$ century, there were a significant number of urban development projects all over the metropolitan area as well as in the historic centre of the city. The aim of urban transformation projects in the former port areas is to revitalise the waterfront, which is characterised by dense and run-down building structures, immense traffic as well as great tourist attractiveness, which seems to be the crucial mixture for processes of gentrification and modernisation. There are increasing discussions among politicians, planners, investors, the mass media and representatives of social urban movements about the significance of the waterfronts, their possible uses and their accessibility as public spaces. 
As in other port cities around the world, Istanbul's urban transformation processes have become symbols or models in relation to global economics, local power structures and the constitution of space (Schubert 2001, see in this volume). Waterfronts, with their exposed visibility, are stages for representing the city (Marshall 2001). Innovative urban planning projects and spectacular new architecture are often used as physical and metaphorical landmarks of a city's prosperity and attractiveness. Different actors and interest groups are involved in the creation of these new urban images. The transformation of waterfronts in their specific economic, social and political - local as well as global - contexts has become a "hot topic" of urban planning and the production of urban space (Bruttomesso 1993). Waterfronts are spaces in transition.

In this context, urban space is defined as a dynamic site of social and cultural constructions, which are materialised in physical places, social interactions, as well as in urban imaginaries and discursive representations (Harvey 1993; Lefèbvre 1994). Space in this sense is seen as cultural, i.e. continuously produced or constituted by structuring and spaceproducing activities (Löw 2001).

Processes of urban planning, social lobbying, material construction and public discussion involve various urban actors. With regard to social and cultural dynamics, these processes of urban transformation are a privileged field for an ethnographic analysis of the constitution and production of space.

To work on space with an ethnographic approach, means to recognise at least two distinct levels of investigation. On the one hand, space is a concrete or material site. Built space provides symbolic meanings as well as physical boundaries (Atkinson 2005). The investigation of these physical places, the ways of experiencing, perceiving and appropriating by different actors in everyday life, is one part of the fieldwork. On the other hand, conceptions of space, manifesting itself in the ideas of a city, in urban planning projects and urban representations need to be investigated in their respective discursive contexts. An ethnographic approach involves the historic development of the sites, descriptions of the physical spaces, the actors and interest groups involved in the process of transformation, as well as the meanings and sometimes contradictory significances of these spaces for everyday life and urban representation.

A possible starting point for ethnographic research on planning processes is the analysis and interpretation of the development of urban master plans. They are results of intensive research of the urban condition; they are manifestations of urban concepts and the basis of urban imaginaries. Developers, politicians, architects, the media and the local community are among the actors involved in the process of development 
and presentation (see Hall 1993: 16). Conflicts and processes of negotiations between these interest groups with their perspectives, imaginaries and practices (of almost inevitable opposite interests) are another possible focus of ethnographic research.

In this article I shall look at the historic development of the waterfront and urban transformation projects in former port areas of Istanbul, "following a discourse" (Marcus 1993) by analysing urban images as well as the processes of planning and negotiation about the waterfront areas of the Bosporus and the Golden Horn, in order to understand the constitution of spaces and public spheres in contemporary Istanbul. As an exemplary case, I shall focus on one urban transformation project which has caused a public debate: The Galataport Project, a conglomeration of warehouses between a main traffic axis and the waterfront, is situated at the European side of the Bosporus shores. It is located close to the tourist attractions of the historic peninsula, as well as to the modern central area of Taksim Square. As a first reference to up-coming transformations of the area, 2005 a private museum for modern art, $I s$ tanbul Modern, opened in one of the warehouses. Galataport Project shows some analogies with other port cities, concerning phases of industrial and economic change, specific strategies of urban planning and the role of cultural industries in processes of globalisation and urban transformation. At the same time there are local perspectives and dynamics, concerning the specific history of the metropolis as well as the contemporary cultural and political situation impacting the process.

In order to contextualise different phases with processes of modernisation and globalisation, I shall briefly describe the history of the development of port activities in Istanbul. In the next section, I shall concentrate on projects and plans of waterfront renewal since the 1980s. In my description of the new master plan, I shall focus on the role of cultural industries in contemporary processes of urban transformation. Detailed descriptions of the site of the Galataport Project and of different actors involved in the planning process, will serve as a basis for an ethnographic perspective on urban images. The article closes with a summary of preliminary findings and hypotheses about the processes of planning and the production of space in former port areas of Istanbul.

\section{History: Istanbul as a port city}

The earliest Byzantine settlements were founded around the Golden Horn about 700, which was used as a natural harbour (Kilic et al. 2005; Müller-Wiener 1994). In the Byzantine era $\left(4^{\text {th }}-7^{\text {th }}\right.$ century) the city be- 
came a centre for political, economic, cultural activities on the transit route of European, Black Sea, Middle East and Far East trade. The harbour was the focal point, where different ethnic groups met and worked. The main axis of the settlement was along the shores of the Marmara Sea (Kiliç et al. 2005). In the late Byzantine era $\left(7^{\text {th }}-15^{\text {th }}\right.$ century), Constantinople was physically transformed into an inward looking city, concentrated around the churches and market places. At this time, the district "Galata" on the northern shores of the Golden Horn became a centre for Genoese traders, hence the city assumed a more cosmopolitan culture with different religions and languages (Kiliç et al. 2005). In the Ottoman period $\left(15^{\text {th }}-19^{\text {th }}\right.$ century) Istanbul symbolised the power of the state. With the change of the dominant religion, buildings of religious worship, constructed on the top of the hills, became representative and defining elements of the city's identity, visible especially from the sea. The main axis of the city and its social dynamics were located towards the Golden Horn, with its specialised trade-harbours. In Ottoman times the waterfront was regarded as a market place, the water itself was the most important medium for transportation. Apart from the private piers of the wealthy classes, there were specific public piers for ferry boats. Mosques, fountains and cafés next to the piers made these sites at the waterfront significant places of social interaction and everyday practice (Bas Butuner 2006: 2).

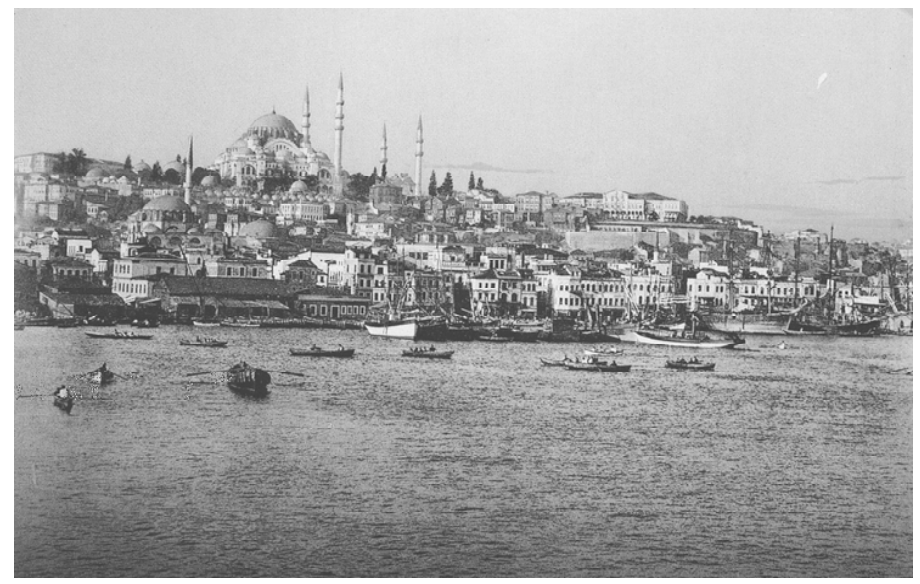

Fig. 2: Postcard, lithograph of the silhouette of the historic peninsular, southern shores of the Golden Horn, $18^{\text {th }}$ century

At the beginning of the $19^{\text {th }}$ century, an area of orientation towards western culture and modernity began, which signified not only transfor- 
mations on political and administrative levels, but also new influences in architecture, urban development and life style. As a symbol of modernity, democratic and secular public squares - some of them close to the waterfront - were created and designed with fountains and clock towers. These objects at striking urban vistas became public monuments of early modern Ottoman society and power (Gönenç 2006: 28f). In the second half of the $19^{\text {th }}$ century, the Ottoman state invested in new harbour facilities in the centre of the city, at the shores of the Golden Horn and the western side of the Bosporus. As an effect of early industrialisation and developing technology, huge warehouses and docks were constructed. The intense production activities and the new structures characterising the connections between production sites and transportation, dominated most zones on the waterfronts, but made the waterfront inaccessible for the citizens at these sites (Bas Butuner 2006: 2).

At the same time, the state began to represent itself with impressive palaces at the waterfront (Interview Esen 03/2007). ${ }^{1}$ The waterfronts of Istanbul became a fragmented mixture of warehouses, docks and portrelated industries, mainly in the part closest to the historic city centre at the Golden Horn and the lower parts of the Bosporus. The aristocratic and wealthy chose areas further up north the Bosporus. At this time, yet another aspect of the use of waterfronts came up: citizens and members of the palace began to use the water for recreation and entertainment, and the first sea baths emerged on fancy sites at the Marmara Sea. With the establishment of the Turkish Republic (1923), new concepts and attitudes towards the use of the waterfront were introduced. The formerly exclusive parts for the wealthy were opened for the general public; beaches and the sea became a site for festivities. Most of the now stateowned former Ottoman palaces at the waterfront were reopened as schools and other public institutions.

\section{Modernisation in the $20^{\text {th }}$ century}

In the second half of the $20^{\text {th }}$ century Istanbul was characterised by rapid industrialisation and an extensive demographic growth, as effects of rural-urban migration. Between the 1950s and 1980s government policies did not address the issue of public housing, but gave priority to urban in-

1 Part of my first explorative fieldwork on urban transformation processes in Istanbul in March 2007 I conducted seven interviews with urban experts as architects, urban activists and writers. Orhan Esen is urbanist, writer and city guide. He published several articles in Turkish and German about urban development processes in Istanbul, see for example Esen 2005. 
frastructure in the form of water pipes, electricity and roads. One aspect of the intensive development of urban infrastructure was the construction of seaside roads along the shores of the Bosporus, the Marmara Sea and the Golden Horn. Following a decree of the constitution of 1983, the waterfront was declared a "public good". The effect of this law was even more construction of highways along the shores, facilitating access to the waterfront by car, but at the same time changing the shore landscape and disrupting the former relation of city and water. Public space became a space for automobilists; the view of the water was a view from the car. Today nearly $80 \%$ of the shores of Istanbul are dominated by highways (Interview Esen 03/2007).

Although in the 1950s there were still busy shipyards and industry along the banks of the Golden Horn as well as warehouses in Karaköy on the Bosporus, a decline of inner city harbour activities was noticeable. Similar to the development of other port cities, Istanbul experienced different phases of industrialisation and de-industrialisation during the $20^{\text {th }}$ century (Hoyle 1988; Schubert 2001 and in this volume). With new technologies and the containerisation of harbour activities, inner city port areas did not meet the needs for space any more, and port functions and port-based industries were relocated. New industrialised and modern harbours on the shores of the Marmara Sea led to the deindustrialisation of inner city port areas and left derelict former industrial sites.

\section{Waterfront renewal after the $1980 \mathrm{~s}$}

The shores of the Golden Horn are a characteristic example of the influences of global changes on urban transformation processes in Istanbul (Çelik 2004). Already from the early 1980s debates increased among politicians and planners about the revitalisation of run-down shipyards and factories, similar to North American and European harbour renewal projects (Bas Butuner 2006; Bezmez 2006). The mayor Bedrettin Dalan initiated the restructuring of large inner city areas, with the aim of transforming "Istanbul from a tired city whose glory resided in past history, into a metropolis full of promise for the twenty-first century" (Keyder/Öncü 1995: 225).

Besides large projects such as the second Bosporus bridge, international luxury hotels and office buildings, there were ambitious plans for the area of the Golden Horn. Before 1984 undesirable industries on the shores were removed in order to create a new downtown business district and to open the waterfront to recreational and cultural activities. In 
spite of intense protests from urban social movements, factories, warehouses and even old neighbourhood structures were torn down (Bas Butuner 2006: 5). Political changes in the late 1980s stopped the finalisation of these ideas. Some the old industrial structures were saved: a former tobacco factory became a private university, a fez factory was turned into a cultural centre, while the slaughter-house planned to be a convention centre is still an unfinished construction site. Now the waterfront is a fragmented area of unfinished building projects, highways, and isolated cultural centres surrounded by empty green spaces with no direct access to the water.

Because of these major transformations, the relationship between water and land changed drastically. Not only was access to the waterfronts reduced by the highway system, but the settlement patterns following the new infrastructure changed the inhabitants' relation to the water (Yenem et al. 1993: 121). New housing projects at the periphery were developed for residents of former inner city neighbourhoods. People did not find work in the port-related factories anymore, but had to look for other jobs, for example in the textile industry. After the constructions of the highway system at the shores and bridges over the Golden Horn, the former ferry-dominated connection between the many piers on both sides lost much of its attractiveness.

In the context of global economics, de-industrialisation and the changing functions of cities in 1990s, new concepts and imaginaries of urbanism were developed.

"As cities shift from industrial to service economies, a major aspect of their success will be in the quality of their urban environments. It is here that the waterfront plays a critical role. Waterfronts are often the most degraded places in the city, being the sites of former industries. Waterfronts are also highly visible locations in most cities. The image of the city can be remade here." (Marshall 2001: 9)

Many concepts of urban prosperity are nowadays directly connected to the transformation of former port areas. Water (including living on the waterfront) has become one of the most important "soft" location factors to measure urban quality of life. Waterfront projects seem to be a panacea for the success of cities in global competition. In the view of many politicians, urban planners and investors, waterfront development projects promise the "relaunch of the city" (Bruttomesso 2001: 47). From the 1980s urban planners, architects and theorist have been debating the possibilities and concepts for former port areas. According to Ömer Karnipak, one of the directors of the Istanbul based internet-platform 
and network of architects Arkitera, Istanbul's waterfronts are the spaces where transformation is debated in public (Interview with Karnipak 01/2007). ${ }^{2}$ Although there are conflicting interests involved, the "re-generation", "re-creation" and "re-composition" of theses areas and their conversion into attractive urban spaces is nowadays a main focus of city planning (Bruttomesso 2001: 40f; Schubert 2001). The new urban silhouettes, as well as the accessibility to the upgraded waterfronts are seen as a resource for urban development (see Marshall 2001: 8). Talking about a multi-functional urban space planners mainly refer to tourism, commerce, leisure and exclusive living spaces. In this neoliberal definition of cities waterfronts are a promising challenge for the future of prospering cities.

\section{Master plan for the $21^{\text {st }}$ century: The role of cultural industries}

In 2004 the Mayor of Istanbul, Kadir Topbas, initiated the Istanbul Metropolitan Planning and Urban Design Center (IMP). At the IMP roughly 500 urban planners, architects, engineers, demographers and social scientists have been working on a new master plan for Istanbul (Staud 2006). The major goals are to control urban growth and prevent a collapse of natural resources (IMP 2006). The intention of the IMP is to keep the city manageable and attractive, referring to concerns of ecology and quality of living. One of the tasks is to decentralise the present mono-centric spatial organisation of central service functions, which means the invention of new business districts and industrial areas on the peripheries of the Asian and the European side. In the planning centre fourteen different teams are working on recommendations for regional planning, earthquake protected housing, public transportation, metropolitan planning, urban design and other issues. Beside a working group "Museum-City", concerned with revitalisation of historic buildings in favour of tourism, one group is working on urban renewal projects in so called "problem areas with substandard infrastructure instalments", including some former port areas (see IMP 2006).

In October 2006 the Istanbul Metropolitan Planning and Urban Design Center presented a first version of the new master plan. Murat Diren, one of the main urban planers at the IMP, emphasises the positive effects of the master plan, although the IMP has only an advisory func-

2 Ömer Karnipak is architect and founding member of the architectural network ARKITERA, see http://www.arkitera.net/. 
tion, since local and national politicians will finally decide about urban projects to be realised (lecture on the Conference "Public Istanbul", January 2006). Diren stresses the significance of the "cultural triangle" formed by historic and cosmopolitan neighbourhoods around the Golden Horn and the southern shores of the Bosporus for the new transformation processes. Planners' and investors' strategies include promoting Istanbul as a destination for global tourism, through cultural heritage, international art festivals and congress tourism, "creating a happening city" (IMP 2006) To emphasise the uniqueness of cities, politicians, urban planers and urban managers (re)invent traditions and (re)construct spectacular architecture to promote cosmopolitan living conditions or commercialised event-culture. As a central element in contemporary urban transformation processes planners and politicians have identified cultural industries as opportunities for urban development (Florida 2002).

"[Cultural industries] provide the means for the revitalisation of run-down, deteriorated neighbourhoods and re-use of historic building stock, including industrial heritage. They also play a crucial role in branding cities and thus contribute to the capacity of cities to become major destinations for cultural tourism. They help to create an urban environment in which the tourists wish to stay longer and visit the city once again." (IMP 2006).

The development and promotion of cultural industries in the film-, festival-, fashion design- and software-sectors, is one of the main targets of urban planning and management in contemporary Istanbul (Keyder 1999: 22). In this context, Culture and the Arts are especially seen as commodities in the global competition of cities.

The inner city waterfronts of Istanbul are attractive sites for new spectacular architecture in combination with cultural industries, tourism and recreation. Therefore, the triangle from the Golden Horn to the southern shores of the Bosporus is dominated by waterfront projects. As in Istanbul cultural interests are largely concerning historical sites, the monuments of Byzantine and Ottoman empires serve as places of identification, as well as magnets for tourism (Çelik 1994: 93). Until now Istanbul was not known as a place of modern art, but with the transformation of the metropolis under parameters of globalisation and cultural industries, interest in modern art has been increasing. Apart from a growing number of art galleries and institutions, since 1987, like in other metropolis (e.g. Rio de Janeiro, La Habana, Seoul) the Istanbul Biennial has transformed the self-conception of the city and its perception from 
outside. Istanbul today presents the image of a vivid active metropolis with growing cultural industries (Kaiç 2005).

In December 2004, Istanbul got its first museum of contemporary art. The museum is promoted by the Istanbul Foundation for Arts and Culture, which is financed by private enterprises. The museum is located in a former warehouse at the banks of the Bosporus. It is part of the $\mathrm{Ga}$ lataport Project, where a cruise terminal and hotels are planned for on the urban waterfront. The inauguration of the museum Istanbul Modern was internationally acknowledged. It was interpreted as an important place of common European cultural heritage and as a further step to "cultural modernisation of the city". 3

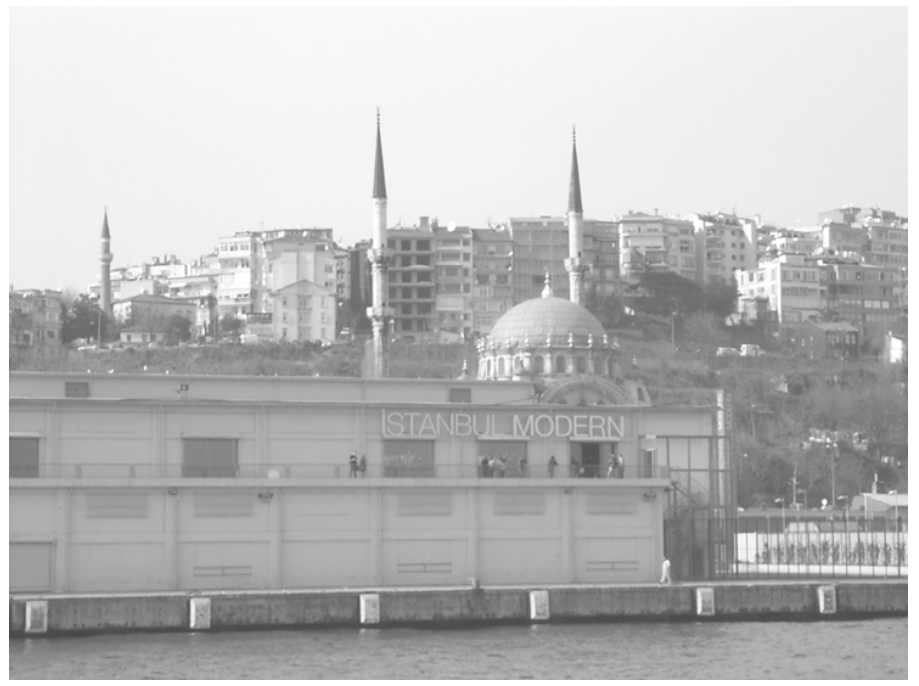

Fig. 3: Museum "Istanbul Modern” (photo: Kathrin Wildner)

\section{Karaköy harbour area}

The significance of the museum "Istanbul Modern" at this specific location can be analysed in the context of the contemporary waterfront development project Galataport. As part of the former Karaköy port area at the western shores of the Bosporus it is one of the main zones of tran-

3 See article about the inauguration of the museum Istanbul Modern on the website of the Turkish enterprise and founder of the museum Eczacibasi, http://www.eczacibasi.com/articles/detail/detaill. asp?id=434\&archive=1, dated 01/07/2005 [26/02/2008]. 
sition in Istanbul. Before the mid- $19^{\text {th }}$ century, this part of the harbour had an important role in trading activities. After the decline of the Ottoman Empire and a big fire in 1863 most of the area was covered by newly constructed port facilities and warehouses. (Erbil/Erbil 2001: 186). When in the1970s Haydarpasa on the Anatolian side became the new container terminal, Karaköy harbour lost more functions and in 1988 was finally closed as a cargo port due to heavy traffic problems caused by the loading and unloading of trucks. At the same time, it still served as a passenger port and became even more important for cruise ships bound for the Black Sea States after the opening of the Russian borders in the early 1990s. Finally there was a new port site opened only for trade with Black Sea states at the Marmara Sea shores (see Erbil/Erbil 2001: 187).

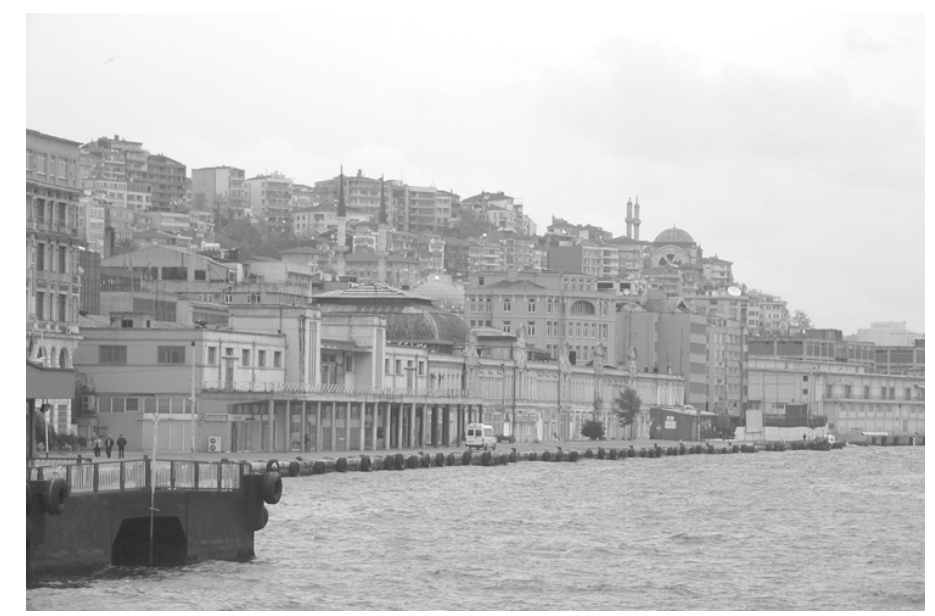

Fig. 4: Waterfront views of Karaköy area (photo: Kathrin Wildner)

Obviously, Karaköy harbour area is a highly attractive zone at the waterfront of the historic city centre of Istanbul. As a consequence, the $\mathrm{Ga}$ lataport Project, a strip of more than one kilometre along the waterfront covering about 8.5 ha of terrain, is one of the currently most valuable urban transformation projects of Istanbul port areas. After closing down the Karaköy harbour area in 1988, the Turkish Maritime Organization (TDI), a state owned enterprise and owner of the terrain, decided to develop the Galataport Project, where - similar to other regeneration projects around the world - the former port area is to be equipped with a cruise terminal, hotels, a shopping centre, cultural and leisure facilities to create a new tourist attraction for millions of visitors to Istanbul (see 
Bas Buntuner 2006: 8). In 2002 the Turkish architecture office Tabanlioglu \& Co. presented their first proposal for the regeneration of this area as a tourist-orientated commercial zone (Gönenç 2006: 51).

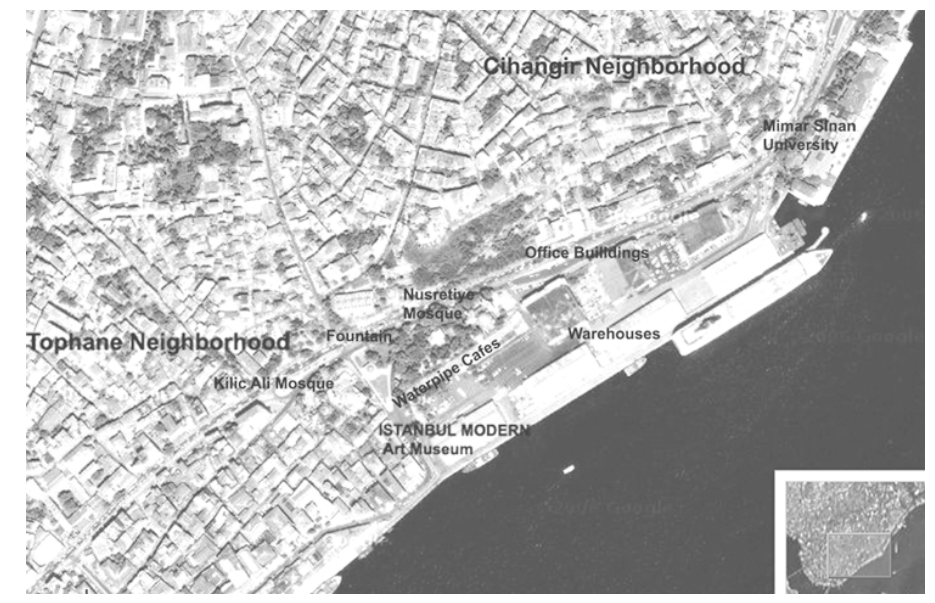

Fig. 5: Area of the Galataport Project (Sacha Essayie)

Today most of the territory at Karaköy harbour including the Galataport Project is still a space in transition. Both banks of the Galata Bridge the ferry boat terminal Eminönü on the Historic peninsula and Karaköy on the Galata side - are busy traffic junctions composed of streets, tram stops and ferry boat terminals. On the Karaköy side next to the bridge, there is a fish market and a vivid public space used by tourists and Istanbul citizens alike viewing the Historic Peninsula opposite. A promenade along the waterfront leads to the Karaköy ferry terminal for commuters to Üskadar and Kadiköy on the Asian side of the city. A mixture of architecture characterises this part of the waterfront. One six story artnoveau style building hosts the Turkish Marina Organisation Turk Denizcilik Isletmeleri, next to it a three-storey building in a modernist international style serves as a warehouse and a terminal for national and international ferry boats. On the ground floors of these office buildings are fish-restaurants and cafe terraces. After about $500 \mathrm{~m}$, the promenade at the waterfront is closed for public access. The buildings seen from the waterside are a composition of older warehouses and office buildings, which are not extensively used anymore. The architecture is a mixture of two-storey buildings from the first half of the $20^{\text {th }}$ century, and some functional modernist structures of the 1950s. Most of the buildings are still in use and seem in bad shape, some are abandoned. 
The heart of the Galataport Project is characterised by four huge warehouses. Now located between parking lots and office buildings, in the $19^{\text {th }}$ century this area was designed as a public space. Between the historic Kiliç Ali Pasa and the Nusretiye Mosques with their surrounding spaces and parks, there is a beautifully decorated $18^{\text {th }}$ century public fountain and one of Istanbul's first clock towers from the early $19^{\text {th }}$ century. The public fountain and the clock tower are reminders of the westernised concepts for places of gathering and political representation (Gönenç 2006: 46).

As there is no access from the waterfront, the Museum can only be entered from the main road, which connects the Karaköy area with the ferry terminal of Kabataş. Nearly hidden behind the Mosque is an entrance to a parking lot surrounded by four huge warehouses. Next to a security booth controlling the access to the parking lot, a red sign indicates that this is also the entrance to Istanbul Modern, the first modern art museum of Istanbul opened in 2004.

After one of the warehouses was used for an art exhibition at the UN Habitat II Istanbul Summit in 1996, the former storage place was used as a venue at the Istanbul Biennial. These activities and appropriation made public access to this area temporarily possible and indicated potential uses of the industrial buildings after years of closure because of harbour activities. Inhabitants of Istanbul became more and more interested in the site and the possibilities to use it as public space. For example from the café terrace of the art museum, which is increasingly visited by (art interested and young) Istanbul citizens, there is a great view of the Bosporus and the Asian side. As the pier along the seaside is still a custom zone, the area is closed off by fences. Huge letters on the facade $I s$ tanbul Modern facing the Bosporus seem like a visual manifestation of an urban imaginary, which extends from the building itself to the silhouette of the waterfront including the urban environment. Right next to the entrance of the museum, between the warehouses, there is a little square with workshops and restaurants. Some of the shops, now used temporarily as workshops, still have English names referring to its former use as the souvenir and shopping area for visitors arriving on the international cruise ships. The incompleteness and run down state of this attractive site at the shores of the Bosporus next to the representative $I S$ tanbul Modern mark this place in an obvious way as an area in transition. And actually this zone, composed of warehouses around a parking lot, is the heart of the urban transformation project Galataport Project. Following the main road, outside the complex of the warehouse buildings, there are more buildings from the 1950s and 1960s hosting banks, 
insurances and local or national administrative institutions, leading to the impressive $19^{\text {th }}$ century building of Mimar Sinan University. This Istanbul Art Academy occupies a space directly at the waterfront, but since the territory is the property of the University public access to the waterfront is not allowed. Past this building the road opens again into a small park, used by citizens for fishing and recreation at the shores. Some informal vendors sell tea. The park leads to the ferry terminal of Kabataş, enlarged in 2006. A new public transportation system connects the ferry terminal with the public transportation system at Taksim Square, so commuters from Kadiköy and Üsküdar from the Asian side are well connected with the modern city centre at Taksim and the new business district of Levent and Maslak. The surrounding neighbourhoods of the Karaköy harbor area and the upcoming Galataport Project are blocked off from the waterfront by a busy road with heavy traffic. On the other side of the road steep streets and stairs lead to the residential neighbourhoods of Tophane and Cihangir. Tophane, part of the former Genoese trader quarter Galata, is today a more or less run down residential area. Most of the old buildings are deteriorated. Close to the former Karaköy harbour there are leftovers of an unofficial red-light district. The population is mainly poor first generation migrants from the eastern provinces of Turkey (Erbil/Erbil 2001: 186). In some parts of Tophane a new kind of small-scale gentrification process pioneered by young artists has been taking place since the late 1990s (Uzun/Yücesöy 2006: 10).

Cihangir, an old residential neighbourhood located on the slope of the hill towards the Taskim place, has one of the city's most beautiful panoramic views on the Bosporus and the Historic Peninsula. From the $16^{\text {th }}$ century onwards a non-Muslim cosmopolitan and elite population has lived here. After the expulsion of the Jewish, Armenian and Greek communities in the 1950s and 1960s the neighbourhood was marked by decline until in the 1990s a gentrification process pioneered by intellectuals and artists took place. The architectural structure of old apartment houses built in the early $20^{\text {th }}$ century and its location close to the central Taksim area nowadays make it an attractive residential area for a wealthy middle class. Cihangir still has an active community structure taking part in the discussions on urban transformation processes (Uzun/Yücesöy 2006: 9f).

The Galataport Project is part of these discussions and ongoing public debates between politicians, investors, architects, community leaders and media about urban planning and the future of this area. With the public presentation of the architectural proposal for the Galataport Project, published in daily newspapers and architectural magazines in 
2005 , the processes of planning as well as a functional regeneration of the waterfront itself became a highly discussed topic.

A closer look at the different actors and their arguments provides a framework for analysing dialectical processes of the production of urban space (Harvey 1993) as well as heterogeneous concepts of public space and urban images in the local context of Istanbul.

\section{Actors of the planning process}

The publication of the architectural plans for restructuring the Galataport Project created an intensive debate about public spaces and their privatisation. Different actors, such as politicians, urban planners, investors and representatives of social movements take part in these debates, in which conceptual backgrounds and imaginaries about urban space are negotiated.

Because of the inefficiency of the Karaköy harbour and its closing, Turkish Maritime Organization (TDI), a state-owned company and present owner of the space, attempted from the late 1980s to privatise the area. In 1990, TDI invited international firms to design a portside facilities concept, a hotel complex and business offices. For the state, economy and the profitable transformation of the former harbour site are the main motives of urban planning. With an international cruise terminal and recreational areas more tourists would be attracted (Erbil/Erbil 2001: 187). As tourism is one of the main branches of the economy of Istanbul the dominant Ministry of Tourism is interested in including this area into the development of the historic city centre and to recreate the waterfront as a tourism and business complex similar to successful models of European and North American cities.

Private investors were invited to compete about the area. The highest bid for port facilities, hotel and recreation came from a consortium of Royal Caribbean Cruises, owned by the Israel Ofer family and Turkish Global Holding. For 3,5 billion US Dollars TDI would lease the Galataport area for 49 years and give the right to build and operate this zone to the investors. But before the investors started the transformation, the project was postponed due to some legal discordance between the national and the local administration (Interview Karnipak 01/2007).

Although the municipality of Istanbul is not completely against this project, their main opposition is based on the fact, that the local administration is not at all involved in the processes of planning for this area. In fact, the central government has been disregarding the actual master plan of the Istanbul Metropolitan Planning Center (IMP) (Erbil/Erbil 2001: 
188). Only recently the IMP, as a municipality based institution, gained influence in decision making by demanding and intensifying public discussions. With their proposal focusing on an urban balance of ecological, functional and cultural aspects (see IMP 2006) the IMP is working as a mediator between economic orientated national ministries and local politicians concerned about a functional urban structure. On the other hand for some urban planners working for the IMP a new urban vision of the historic part of Istanbul is related to the focus on cultural industries. Karaköy harbour is seen as a central part of a "cultural triangle" around the Golden Horn and the western Bosporus shores up to Kadiköy on the Asian side (IMP 2006). Historical heritage, tourism and contemporary cultural activities (e.g. film and software sector, cultural festivals and fairs as well as art exhibitions) are in this context not only profitable parameters of a location factor, but are seen as promising elements of urban space and the cultural identity of a city. Knowing about the importance of cultural identity for the urban image of the city, architects try to give meaning to spaces by "keeping alive memory of the places in form of marinas", thinking about a mixture of private and public spaces in the form of hotels as well as "traditional public spaces", such as plazas, streets, parks and museums (Bruttomesso 2001: 45f).

Another important actor in the process of urban planning in Istanbul is the Chamber of Architects. Traditionally, the Chamber is the institutional board for all topics concerning architecture. The members are proud of their cosmopolitan Istanbul lifestyle, seeing architecture as an art. They do not always agree with the plans of urban transformation developed by politicians and urban planers. In fact, the Chamber is a strong opposing institution in the specific arrangement of actors in the field of urban transformation. In the case of the Galataport Project, members of the Chamber tried to stop the restructuring plans. The project was criticised for destroying the historical characteristics and the silhouette of the site. They argued that by building high-rise buildings the historic city-scape of Istanbul would be destroyed and the views would be blocked (Bas Butuner 2006: 8). This argument refers to the significance of the waterfront for the urban image of Istanbul. The specific geographic situation of Istanbul as formed by the three pieces of land divided by large expanses of water, the hilly topographic situation and the steep slopes of the shores mark the identity of the city. The water separates the three parts of the city and at the same time joins them together as a unit. The view over the water to the respective other side of the city is one of the important identifying urban elements. "These expanses (of water) transform themselves into ritualized spectacles, have long since been the principal reason for Istanbul to be known as a legen- 
dary home to vistas" (Bilgin 2006: 3). Since the city planning of the late Ottoman times, silhouettes and panoramiv views are continuously praised and represented in literature, postcards, official advertisements and in everyday life (Bilgin 1998: 2041).

The silhouette and vista is one of the most important elements of identification with the city for settled Istanbul citizens. The professor for regional and urban planning at the Mimar Sinan Architectur faculty, Aykut Karaman, claims the water parts of Istanbul as an open public space in the sense of an urban image, a common experience and a parameter of urban identity (Interview Karaman 02/2007). In this context arguments against the Galataport Project refer to the dangers of privatisation, which would diminish the possibility for citizens to use this area as a recreational space (Erbil/Erbil 2001:188). Accessibility is also a major argument of non-government organisations and organisations in the nearby neighbourhoods of Cihangir and Galata are against the urban transformation project. They are demanding the public space for the inhabitants of the very densely populated structures of their neighbourhoods. The Cihangir neighbourhood association has mainly been active in formulating their interests in opposition, reclaiming the harbour area as the only possible opening to the sea and proposing a more open use of the waterfront with public walkways, cafes, restaurants and other recreational facilities instead of shopping malls for tourists (Erbil/Erbil 2001:188). The editors of the quarterly magazine Istanbul focusing on urban discussions, claim that shopping malls and cafes are not public meeting places for the people living in the neighbourhood, but that they have only commercial use (Interview Morgul/Atayurt 04/2007). In this sense, more radical artist groups of the Galata neighbourhood criticise, that shopping malls which are supposed to be free for public access, would be restricted by pricing policy, which will keep a vast majority of city dwellers outside (x-urban 2006). These critical groups interpret the opening of the Istanbul Modern art museum and the spectacular events for special invitees as a first step towards establishing an exclusive production of culture, which is to be expected at the Galataport Project (xurban 2006). In their perspective the museum serves as an attractive stimulation for investors to present possibilities of cultural industries in recreating the abandoned waterfront.

These few examples of actors involved in the planning process, and of discussion about the transformation of the former Karaköy port area into the Galataport Project, demonstrate different interests and definitions of urban public space. The arguments and statements show divergent ideas concerning economic, functional or social attributions to urban space and possibilities of every day appropriation. 


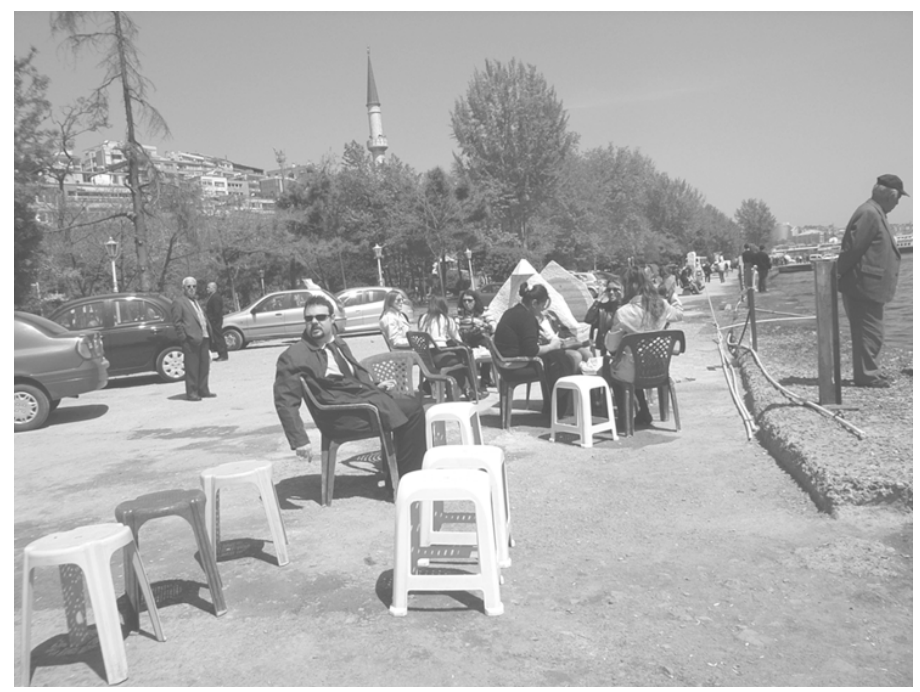

Fig. 6: Waterfront as public space, a temporary tea garden. (photo: Kathrin Wildner)

\section{Conclusion}

Waterfront areas in Istanbul are undergoing a significant transformation, which can be contextualised in the processes of de-industrialisation and global competitions of cities. The revitalisation of former port areas, as the example of Galataport Project has shown, is an important element of contemporary urban planning in Istanbul. In comparison to other port cities there are similar structures and concepts for the transformation of former port areas into tourist attractions by implementing cruise terminals, hotels and office buildings.

But at the same time there are specific local aspects of the planning process, concerning arguments and actors involved in the discussions. In the case of Istanbul water and waterfront as a central urban image have a significant (and historic) meaning for identification with the urban space. Analysing these arguments in more detail will be the object of further research and fieldwork, with the aim of understanding the complexity of urban planning processes and the constitution of space.

The preliminary results described in this article show that the process of transformation of the waterfront in Istanbul is not simply a question of architecture or urban design, nor is it just to be interpreted in the global context of economy and global competitions of cities. Plan- 
ning processes provoke oppositions and create spaces for discussions about the future of urban space. The discussions about the meaning and form of urban spaces can be analysed as "space-producing activities", and they are related to the main political topics in contemporary Turkey. Ethnographic research of local urban planning processes, by means of analysing the physical space, social interactions and the urban images produced in public debates, can provide in-depth information about contemporary discourses and the imaginary of urban space.

\section{References}

Atkinson, Paul (2005): "Qualitative Research - Unity and Diversity". Forum Qualitative Social Research 6 (3), Art. 26 (http://www.quali tative-research/net).

Bas Butuner, Funda (2006): "Waterfront Revitalization as a Challenging Urban Issue in Istanbul". Paper presented at $42^{\text {nd }}$ IsoCaRP Congress 2006, Istanbul.

Bezmez, Dikmen (2006): "The Politics of Urban Waterfront Regeneration: the Case of Halic, Istanbul". Paper on ISA Conference, Durban. Bilgin, Ihsan (1998): “Istanbul: Stadt am Wasser”. Stadtbauwelt 36, pp. 2040-2043.

Bilgin, Ihsan (2006): "Istanbul's Urban Structure and Transformation". Paper presented at the Conference 'Public Istanbul' (19-20/01/2007) Weimar.

Bruttomesso, Rinio (ed.) (1993): Waterfronts. A New Frontier for Cities in Water, Venice: International Centre Cities on Water.

Bruttomesso, Rinio (2001): "Complexity on the Urban Waterfront". In: Richard Marshall (ed.), Waterfronts in Post-Industrial Cities, London/New York: Spon Press, pp. 39-51.

Çelik, Zeynep (1994): "Urban Preservation as Theme Park: The Case of Sogucesme Street”. In: Zeynep Çelik/Diane Favro/Richard Ingersol (eds.), Street. Critical Perspectives on Public Space, Berkeley: University of California Press, pp 83-95.

Erbil, Ögut Ayşe/Erbil, Tansel (2001): "Redevelopment of Karaköy Harbor, Istanbul. Need for a New Planning Approach in the Midst of Change". Cities 18 (3), pp. 185-192.

Esen, Orhan (2005): "Learning from Istanbul. Die Stadt Istanbul: Materielle Produktion und Produktion des Diskurses". In: Orhan Esen/ Stephan Lanz (eds.), Self Service City Istanbul, Berlin: b-books, pp. 33-55. 
Esen, Orhan/Lanz, Stephan (eds.) (2005): Self Service City Istanbul, Berlin: b-books.

Florida, Richard (2002): The Rise and Fall of the Creative Class, New York: Basic Books.

Gönenç, Murat Efe (2006): Public Spaces: Discussions, Analyses and a Proposal for the Case of Tophane-Salipazari Area, Istanbul. Institute of European Urban Studies, Bauhaus University, Weimar: unpublished master thesis.

Güvenç, Murat/ Isik, Oguz (2002): “A Metropolis at the Crossroads: the Changing Social Geography of Istanbul under the Impact of Globalization”. In: Peter Marcuse/Ronald van Kempen (eds.), Of States and Cities. The Partitioning of Urban Space. Oxford: Oxford University Press, pp. 200-217.

Hall, Peter (1993): "Waterfronts: A new urban frontier". In: Bruttomesso, Rinio (ed.), Waterfronts. A New Frontier for Cities in Water, Venice: International Centre Cities on Water, pp. 12-21.

Istanbul Metropolitan Planning and Urban Design Center, IMP (2006): Istanbul Metropolitan Master Plan. Booklets, Istanbul.

Harvey, David (1993): "From Space to Place and Back Again: Reflections on the Conditions of Postmodernity". In: Jon Bird et al. (eds.), Mapping the Futures, London: Routledge, pp. 3-29.

Keyder, Çağlar (1987): State and Class in Turkey: A Study in Capitalist Development, New York: Verso Press.

Keyder, Çağlar (1999) "Istanbul”. In: Çağlar Keyder (ed.) Istanbul. Between the Global and the Local. Lanham: Rowman and Littlefield Publishers, pp 3-28.

Keyder, Çağlar/Öncü, Ayşe (1993): Istanbul and the Concept of World Cities, Friedrich Ebert Foundation, Istanbul.

Keyder, Çağlar/Öncü, Ayşe (1994): "Globalisation of a Third-World Metropolis: Istanbul in the 1980s”. Review 17 (3), pp. 383-421.

Kaiç, Dragan (2005): Istanbul's Cultural Constellation. www.labfor culture.org [26.4.2007]

Kiliç, Ali et al. (2006): "Culture Coming through Water and City/Inhabitant that Doesn't Live this Culture; the Case of Istanbul, Tuzla Settlement". Paper presented on $42^{\text {nd }}$ IsoCaRP Congress 2006, Istanbul.

Kortun, Vasif (2004): "Public Spaces - Privat Views". In: Institut für Auslandsbeziehungen - ifa-galerie (ed.), Stadtansichten Istanbul, Stuttgart: ifa, pp. 4-12.

Lefèbvre, Henri (1994): The Production of Space, Oxford.

Löw, Martina (2001): Raumsoziologie, Frankfurt/M.: Suhrkamp. 
Marcus, George (1995): "Ethnography in/of the World System - The Emergence of Multi-Sited Ethnography". Annual Review of Anthropology 24, pp. 95-117.

Marshall, Richard (ed.) (2001): Waterfronts in Post-Industrial Cities, London/New York: Spon Press.

Marshall, Richard (2001): "Contemporary Urban Space-Making at the Water's Edge”. In: Richard Marshall (ed.), Waterfronts in Post-Industrial Cities. London/New York: Spon Press, pp. 3-15.

Müller-Wiener, Wolfgang (1994): Die Häfen von Byzantion Konstantinupolis, Istanbul, Tübingen: Wasmuth Ernst Verlag.

Robins, Kevin/Aksoy, Asu (1995): "Istanbul Rising: Returning the Repressed to Urban Culture". European Urban and Regional Studies 2 (3), pp. 223-235.

Schubert, Dirk (2001): "Revitalisierung von (brachgefallenen) Hafenund Uferzonen in Seehäfen - Anlässe, Ziele und Ergebnisse sowie Forschungsansätze und -defizite". In: Dirk Schubert (ed.), Hafen und Uferzonen im Wandel. Analysen und Planungen zur Revitalisierung der Waterfront in Hafenstädten, Berlin: Leue: pp. 15-36.

Staud, Toralf (2006): "Chaos ohne Kollaps". Greenpeace Magazin 4, (http://www.greenpeace-magazin.de/index.php?id=2763) [15/03/2008]

Uzun, Nil/Yücesöy, Eda (2006): “Contested Public Spaces vs. Conquered Public Places". Paper presented at the Conference 'Public Istanbul' (19-20/01/2007), Weimar.

Yenen, Zekiye et al. (1993): "Istanbul: A City of Waterfronts or a City Inland”. In: Rinio Bruttomesso (ed.), Waterfronts. A New Frontier for Cities in Water, Venice: International Centre Cities on Water, pp. 116-124.

X-Urban (2006): An interim report: Istanbul Exclusive 1/2006, (http:// www.xurban.net/notion/interim.htm) [27/04/2007]. 


\section{Authors}

Alfonso, Carolin, holds an M.A. in social anthropology. Her main areas of interest are urban anthropology, migration and diaspora. She conducted her field work in Algeciras (Spain) in 2003 and 2004.

Bothfeld, Anke, holds an M.A. in Eastern European history and social anthropology. Her major areas of research include diaspora, urban transformation and planning cultures. She has carried out research in Odessa, Varna and Hamburg in 2002, 2005 and 2006.

Dohrn, Reimer, Dipl.-Psych., is a certified psychologist and studied social anthropology at Hamburg University. His chief areas of research include labour and refugee studies. He conducted his field research in Hamburg in 2004 and 2005.

Gandelsman-Trier, Mijal, completed her M.A. in social anthropology at Hamburg University. She is currently a doctoral candidate and lectures social anthropology in Bremen and Hamburg. Her key areas of interest are diaspora, space and place and urban anthropology. She conducted her field work in Montevideo (Uruguay) in 2003, 2004 and 2005 .

Kokot, Waltraud, $\mathrm{PhD}$, is professor of social anthropology at Hamburg University. Her teaching and research areas include diaspora, urban anthropology, refugee studies, urban poverty and homelessness. She has conducted field research in Thessaloniki, Sofia and Hamburg.

Oesselmann, Dirk, Dr. phil., graduated in theology and obtained his doctorate in education studies. He is professor of education and cultural diversity at the Universidade da Amazônia in Belém (Brazil) and coordinator for global education at the Comenius Institut in Münster 
(Germany). His research interests include migration, youth and urban poverty.

Oesselmann, Rosemarie, Dr. phil., social anthropologist, conducted field work in São Paulo (1991 and 1992) and Belém (Brazil) in 1995, 1996 and 1999. Her major areas of research are migration, urban anthropology and urban poverty.

Schubert, Dirk, Dr. rer. pol., is senior lecturer at the HafenCity University Hamburg. His main areas of research are urban development and planning, revitalisation of harbour and waterfront areas. He has conducted research in Hamburg and other international port cities.

Stroux, Salinia, holds an M.A. in social anthropology. Her major area of research is refugee studies. She has carried out field work in Athens, Thessaloniki and Hamburg.

Wildner, Kathrin, Dr. phil., is lecturer of social anthropology at Viadrina University (Frankfurt/Oder) and Hamburg University. She is an accomplished researcher of urban anthropology, space and place. She has conducted field work in New York City, Mexico City, Hamburg and Istanbul.

Wonneberger, Astrid, Dr. phil., is currently a lecturer of social anthropology at Hamburg University. Her major academic interests include diaspora, ethnicity and urban anthropology. She has completed field research in Western Ireland, New York, Boston and Dublin (Ireland). 